ERDÉLYI TUDOMÁNYOS FÜZETEK

266

\title{
VARGA P. ILDIKÓ
}

\section{HIISI SZARVASÁTÓL A CSODASZARVASIG}

A Kalevala magyar fordításai

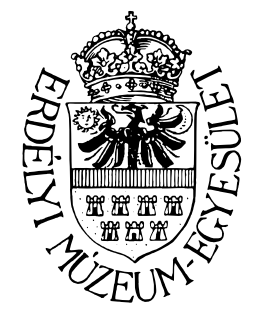

Kolozsvár, 2010 
A kötet megjelenését a Communitas Alapítvány

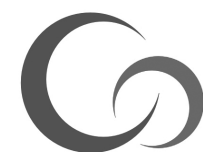

\section{COMMUNITAS \\ ALAPÍTVÁNY}

Alapította az RMDSZ

támogatta.

(C) Varga P. Ildikó

(C) Erdélyi Múzeum-Egyesület, 2010

Felelős kiadó

BIRÓ ANNAMÁRIA

Korrektúra

DEMETER ZSUZSA

Müszaki szerkesztés, tördelés

BODÓ ZALÁN

Nyomdai munkálatok

GLORIA, Kolozsvár

Felelős vezető

NAGY PÉTER

Descrierea CIP a Bibliotecii Naționale a României

VARGA ILDIKÓ P

Hiisi szarvasától a csodaszarvasig: a Kalevala magyar fordításai /

Varga P. Ildikó. - Cluj Napoca: Societatea Muzeului Ardelean, 2010

Bibliogr.

ISBN 978-606-8178-18-9

$821.511 .111-91=511.141$

81'25:821.511.111.09 


\section{TARTALOM}

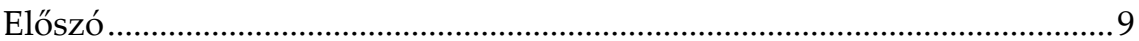

1. Elméleti és módszertani megfontolások ...................................................13

1.1. Az elméleti keretről ............................................................................. 14

1.1.1. A többrendszerűség elmélete...................................................14

1.1.2. A leíró (deskriptív) fordítástudomány ……………………........ 15

1.1.3. A finnugor háló fogalma .......................................................17

1.2. A fordítások vizsgálatának módszeréről ..........................................17

2. Nemzeti törekvések: finnek és magyarok...................................................21

2.1. Finnország a 19. században .............................................................. 22

2.1.1. Történelmi háttér .....................................................................22

2.1.2. Finnesedési törekvések a 19. század első felében:

a finn nyelvkérdés ............................................................................24

2.1.3. A történelem, nyelv és irodalom szerepe a nemzetté válás

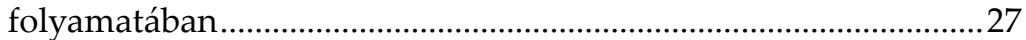

2.1.4. A finn nemzettudat és a nyelvrokonsághoz való finn

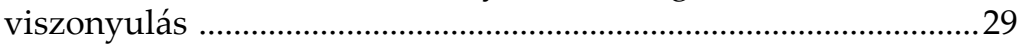

2.2. A Kalevala létrejötte ........................................................................ 31

2.2.1. Népköltészeti gyűjtések az 1700-as évek végén, az 1800-as

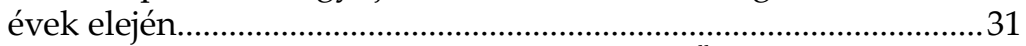

2.2.2. Runógyűjtemény Väinämöinenről. Az Ős-Kalevala ..............33

2.2.3. A Kalevala első kiadása. A Régi Kalevala ................................35

2.2.4. A Kalevala második kiadása. Az Új Kalevala..........................39

2.3. A nemzet fogalmának változása a magyaroknál és a nemzeti

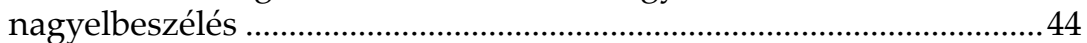

2.3.1. Nemzetfogalmak és irodalomfelfogások .................................4 44

2.3.2. Eposz legyen-e vagy regény? ...................................................... 46

2.3.3. Nemzetfogalmak és a finnugor nyelvrokonsághoz való magyar viszonyulás ..................................................................... 48

2.3.4. A magyarság önképe a 19. század végén és a 20. század elején. 
2.4. A nyelv- és/vagy néprokonságon alapuló magyar-finn

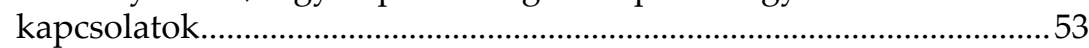

2.4.1. Félhivatalos kapcsolatok: a néprokonsági munka.................53

2.4.2. A magyar-finn kapcsolatok intézményesülése ........................56

2.4.3. A magyar-finn kapcsolatok az 1950-es évektől

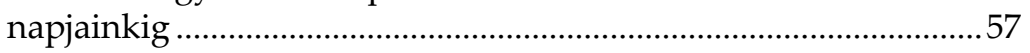

3. Két kísérlet a finnugor háló megteremtésére ………………………….......61

3.1. Első kísérlet - Barna Ferdinánd fordítása ..........................................61

3.1.1. Finnugor mitológiát rekonstruáló törekvések ........................62

3.1.2. Korabeli viszonyulás Barna rekonstruáló

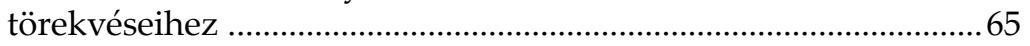

3.1.3. A fordítás rehabilitálása új szempontok

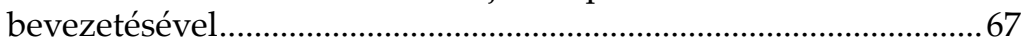

3.2. Második kísérlet - Vikár Béla fordítása ................................................70

3.2.1. Vikár fordítói stratégiája és viszonyulása elődjéhez .............70

3.2.2. Felkészülés a feladatra: az etnográfus Vikár ...........................74

3.2.3. Finnugor háló teremtése - kis segítséggel ...............................75

3.2.4. A működő finnugor háló ........................................................... 82

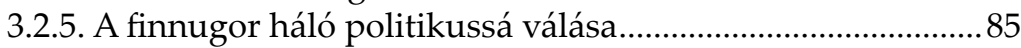

3.2.6. Fogadtatás a finnugor hálón kívül...........................................90

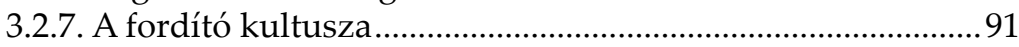

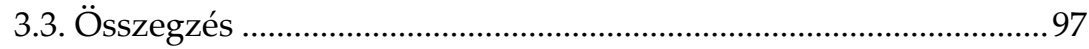

4. Paradigmaváltás a fordításelméletben - új magyar Kalevalák...............101

4.1. A fordításról való gondolkodásról a magyar

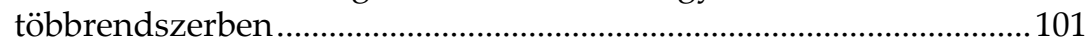

4.1.1. A 19. század közepétől a nyugatosokig...................................101

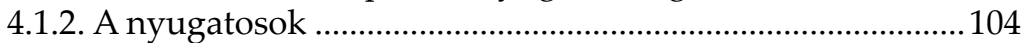

4.1.3. A 20. század 50-es éveitől a 70-es évek végéig .....................105

4.1.4. A 80-as évektől napjainkig .....................................................107

4.2. A köznyelvü, erdélyi Kalevala - Nagy Kálmán fordítása ............109

4.2.1. A formailag hű fordítás ideálja ..............................................109

4.2.2. Erdélyiség a nyelvhasználatban ............................................112

4.2.3. A legjobb magyar Kalevala? - Gáspár Sándor

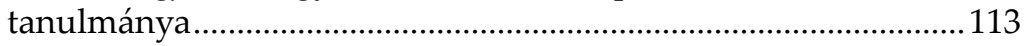

4.2.4. A fordító erdélyisége................................................................114

4.3. A „vikárul beszélő" és a köznyelvű Kalevala között -

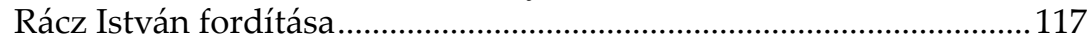

4.3.1. A fordítás költőisége................................................................117

4.3.2. A vikári örökség hozadéka......................................................118

4.3.3. Két kiadás - két koncepció? ……………………………........120

4.4. A honosított Kalevala - Szente Imre fordítása ................................122 
4.4.1. Kiadói politikák - politika a kiadatásban 122

4.4.2. Az újrafordítói szerep és megnyilvánulásai 123

4.4.3. A honosítás módjairól 125

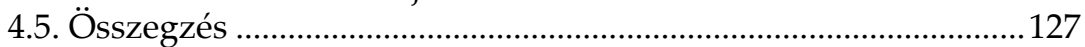

5. A teljes magyar Kalevalák összehasonlító vizsgálata .............................131

5.1. Különbségek és hasonlóságok a célszövegekben ...........................132

5.1.1. A fordítások formai jellemzői ...............................................133

5.1.2. A forrásszöveg személy- és földrajzi nevei

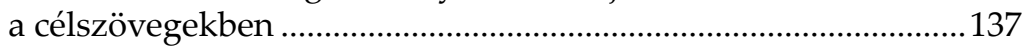

5.2. Tartalmi különbségek a célszövegekben......................................142

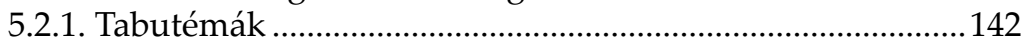

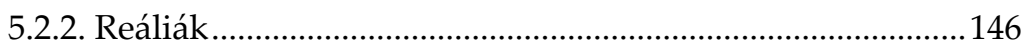

5.2.3. A magyar kultúrkörhöz kötődő vendégszövegek

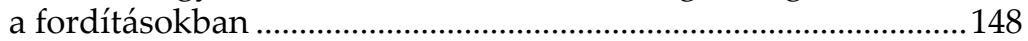

5.3. A forrás- és célnyelvi szövegek összevetése ....................................151

5.3.1. Az elő- és utóhang ................................................................... 152

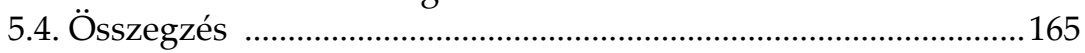

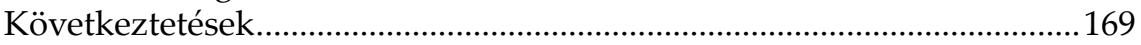

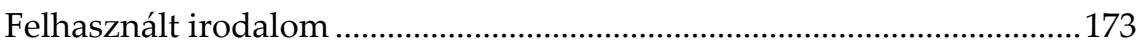

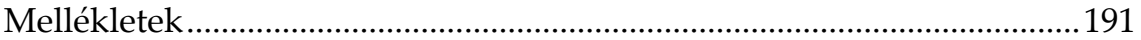

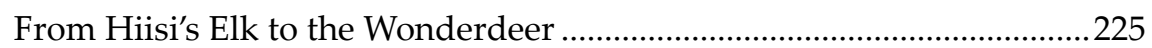

De la cerbul lui Hiisi până la Cerbul Miraculos ...........................................229 



\section{ELŐSZÓ}

Ez a könyv a Kalevala magyar fordításaival foglalkozik. Témaválasztásomat legfőképpen az indokolta, hogy hiányzik a magyar Kalevala-kutatások és Kalevala-irodalom színteréről egy olyan munka, amely a fordításokat helyezné a kutatás fókuszába, és valamilyen fordításelméleti keretbe helyezve vizsgálná azokat és fogadtatásukat. A finn eposznak öt teljes magyar fordítása van, sorrendben a fordítók és az első megjelenés éve szerint: Barna Ferdinánd 1871, Vikár Béla 1909, Nagy Kálmán 1972, Rácz István 1976, Szente Imre 1987. Részleteket fordított még Reguly Antal, Hunfalvy Pál és Fábián István a 19., valamint Képes Géza és Varga Domokos a 20. században. Munkámban kizárólag a teljes fordításokkal foglalkozom.

\section{Elözmények: a magyar Kalevala-kutatásokról}

A Kalevala 1835-ös finnországi megjelenése óta beszélhetünk az eposz iránti magyar érdeklődésről, hiszen a Literaturai Lapok már 1836-ban tudósított a finn eposz megjelenéséről. 1841-ben pedig az éppen Finnországban tartózkodó Reguly Antal fordított is a Régi-Kalevalából. A 20. században a finnugor nyelvészettel, néprajzzal, kultúrával foglalkozó szakemberek közül Korompay Bertalan a Kalevala keletkezésével, Szíj Enikő, A. Molnár Ferenc az eposz magyarországi útjával és az első részfordításokat elkészítő Regulyval, napjainkban Voigt Vilmos többek között a szerkesztő Lönnrotra ható görög mintával foglalkozik.

A Kalevala fogadtatás- és hatástörténetéről is többen írtak. Domokos Péter A finn irodalom fogadtatása Magyarországon címü könyvének első részét kifejezetten a finn eposz magyar fogadtatásának szenteli: kronologikus sorrendben ismerteti a Kalevalával kapcsolatos írásokat. A könyv végén található jegyzetanyag rendkívül adatgazdag, és óriási segítséget jelentett munkám megírásában. Ugyancsak nagy hasznát vettem a Szopori-Varpio szerzőpáros Ismerkedő ismerősök címü könyv függelékének. A szerzők, ahogyan célkitüzésükben is megfogalmazzák, a Kalevalán kívüli 
magyarul megjelenő finn irodalmi művek fogadtatását vizsgálják, a finn eposszal csak utalásszerủen foglalkoznak. A finn irodalom magyarországi recepciójára vonatkozó általános megállapításaikat hasznosnak véltem, és munkámban felhasználtam. Bereczki Gábor egyik 1988-as írásában szintén arra hívja fel a figyelmet, hogy a Kalevala magyar fogadtatását külön kell választani a finn irodalom magyar recepciótörténetétől. A finn eposz ugyanis a magyar kultúrában olyan alapvető szerepet tölt(ött) be, mint a finnen kívül semmilyen más kultúrában. ${ }^{1} \mathrm{Az}$ okok között a magyar irodalomból hiányzó nemzeti eposzt jelöli meg, és azt a tényt, hogy a Vikár Béla fordításában napvilágot látott Kalevala részben ezt a hiányt pótolta. Ezzel a megállapítással én sem vitatkozom. Azonban bennünket az a stratégia érdekel, amellyel ezt Vikár és elődje megvalósítani próbálta.

Fehérvári Győző Dalnak új utat mutattam címü munkája a finn és az észt eposz összehasonlító elemzését tartalmazza, valamint a kettő magyarországi fogadtatását és hatását vizsgálja, külön fejezetben foglalkozik a magyar Kalevala-fordításokkal. Ahogyan a szerző célkitűzésében is megfogalmazza, munkája a két eposz egymáshoz való viszonyára fókuszál leginkább, az összehasonlító irodalomtudomány adta lehetőségeken belül mutatja be a két eposz hasonlóságát és különbözőségét, előzményeiket, keletkezéstörténetüket, érintkezési pontjaikat és a két mű hatását az adott irodalom egészére. ${ }^{2}$

A Kalevala hatástörténetéről Lisztóczky László írt $A$ csodaszarvas a Kalevala erdejében címü munkájában. Könyvemben hatástörténettel nem foglalkozom, ezért az csak érintőlegesen jelenik meg a Vikár-fordítás fogadtatását vizsgáló alfejezetben.

E könyv alapját a 2009-ben megvédett, dr. Kozma Dezső irányításával készült doktori disszertációm képezi, mely nem készült volna el az MTA Domus Hungarica Scientiarum et Artium, a Határon Túli Magyar Tudományosságért Ösztöndíj Program vagy a finnországi CIMO-nak a Helsinki Egyetemen biztosított ösztöndíjai nélkül. Jelen munka disszertációmnak és a témában eddig publikált vagy éppen megjelenés alatt álló tanulmányaimnak ${ }^{3}$ újragondolt változata. Ebben fóként közvetlen kollegáimnak M. Bodrogi Enikőnek és Jankó-Szép Yvette-nek -, valamint doktori dolgozatom opponenseinek - Benő Attilának, Csepregi Mártának és Simoncsics Péternek - megjegyzéseit hasznosítottam.

\footnotetext{
${ }^{1}$ Vö. BERECZKI 1988: 67.

${ }^{2}$ FEHÉRVÁRI $2002 b: 9$.

${ }^{3}$ VARGA P. 2004, 2006, 2007a, 2007b, 2007c, 2008a, 2008b, 2009, 2010a és 2010b
} 


\section{A könyv szerkezeti felépítéséról}

A finn eposz teljes magyar fordításainak vizsgálata tulajdonképpen a Kalevala magyar fogadtatásának története. Ez pedig nemcsak a magyar fordításokhoz kötódik szorosan, hanem kulcsszerepet játszik benne a fordítók és a személyükhöz kapcsolódó viszonyulás is. Ezt szem előtt tartva a fordítók személyéhez kötötten foglalkozom a célnyelvi szövegek recepciójával két fejezetben, a Két kísérlet a finnugor háló megteremtésére és a Paradigmaváltás a fordításelméletben - új magyar Kalevalák címüekben. Az öt teljes magyar fordítás fogadtatását azért vizsgálom két külön fejezetben, mert bár mindegyikben érvényesíthető a korabeli fordításról vallott gondolkodás szempontja, a fordítói intenciók olyannyira különböznek egymástól, hogy elkerülhetetlen volt a két fejezetbe tagolás. Az első két fordító esetében a célnyelvi közösség szem előtt tartása összefonódott egy általam finnugornak nevezett háló megteremtésének szándékával. Az utolsó három fordításban pedig a finnugor háló háttérbe szorulásával, a kanonizált Vikár-fordítással szemben kialakított, fordításelméleti elveken alapuló magatartás éppen a vikári hagyomány újraértelmezésével kapcsolódott össze.

Ezt a két fejezetet előzi meg a finn és a magyar kultúra többrendszereit taglaló, a Nemzeti törekvések: finnek és magyarok címü fejezet, mely kiemelten foglalkozik a finn eposz keletkezésével. Annál is inkább, mivel - véleményem szerint - a magyar fogadtatásban az egyik legmeghatározóbb szempont éppen a finn eposz keletkezésére fókuszál: a műfaji kérdésekre, valamint az eposznak a finn nemzeti identitás megkonstruálásában és megerősítésében játszott szerepére. Ezt követi a magyar, vagyis a célkultúra többrendszerének áttekintése. Ennek vázolásakor a nemzet fogalmának 19. századi értelmezését és a nemzeti nagyelbeszélés müfaji kérdéseit egyaránt érintem. Ugyancsak itt lesz szó a finnugor nyelvrokonság és a finn-magyar kapcsolatok történetéről.

A magyar fordítások összehasonlító vizsgálata első lépésben általánosabb szinten mozog: a formai és tartalmi különbségeket elemzem a teljes szövegekben, ezt követi az átváltási műveletek vizsgálata az elő- és utóhangban. Teszem ezt úgy, hogy a fogadtatással foglalkozó fejezetek végén megfogalmazott előfeltevéseket állandóan szem előtt tartom.

Az Utószóban a szövegszintű vizsgálat eredményeiből kiindulva értelmezem a fordítások helyét és szerepét a magyar irodalomban és válaszolok az alábbi hipotézisekre. 
Hipotézisek:

1. A Kalevala 19. századi lefordításában a finn eposz gyors világirodalmi központba kerülése mellett a két nyelv rokonsága is közrejátszott.

2. Magyarország és Finnország nyelvrokonságon alapuló államközi kapcsolatai a 20. században játszottak meghatározó szerepet a Kalevala magyar fogadtatásában.

3. Barna Ferdinánd és Vikár Béla Kalevala-fordításai a célkultúrában a hiányzó magyar eposz okozta ür betöltését célozták a nyelvrokonságból kiindulva, a finnugor hálón belül.

4. A két első fordítás eltérő fogadtatásában fontosnak bizonyult a fordítók személye is: Vikár fordításának kanonizál(ód)ása több tényező szerencsés együttállásának, valamint Vikár önkultusz-konstruáló stratégiájának is eredménye.

5. A három utolsó átültetés - Nagy Kálmáné, Rácz Istváné és Szente Imréé - többek között a vikári fordítás archaikus nyelvezetével szemben, mintegy arra válaszként született. Ez eltérő viszonyulást eredményezett a forrás- és célkultúrához. Fogadtatásukban nemcsak a Vikár-fordítástól vagy egymás fordításaitól való megkülönböztethetőség, hanem ez a viszonyulás is meghatározó volt.

6. A három utolsó átültetést életre hívó újfajta elvárások, melyeket általában a fordítással - esetünkben a Vikár-szöveggel - szemben támasztottak, azt eredményezték, hogy a vikári kanonizált Kalevala helyét csakis egy teljesen más koncepciójú szöveg vehette át. 


\section{ELMÉLETI ÉS MÓDSZERTANI MEGFONTOLÁSOK}

Munkám célkitűzése: az öt teljes magyar fordítás vizsgálatán keresztül meghatározni a Kalevala helyét és szerepét a magyar irodalomban.

Kutatásaim kezdetén ugyan a jaussi recepcióesztétika kínálta magát elméleti keretként, a kutatás előrehaladtával azonban olyan elméleti munkákkal kezdtem foglalkozni, melyek a fordításra, a fordítás elemzésére nagyobb hangsúlyt fektetnek. Ilyennek bizonyult a többrendszer-elmélet és az ebből mintegy kinövő leíró vagy deskriptív fordítástudomány és ez utóbbihoz szorosan kapcsolódó José Lambert és André Lefevere munkái. A többrendszerüség elmélete Itamar Even-Zohar nevéhez füződik és Izraelből indult, akárcsak Gideon Toury deskriptív fordítástudománya. José Lambert és André Lefevere pedig Belgiumban kezdett el fordításokkal foglalkozni. Hogy miért pont Izraelben és Belgiumban jöttek létre ezek az iskolák? Az egyik ok az adott országok hasonló társadalmi-politikai helyzete. Kis nyelveket beszélő társadalmakról van szó, melyekre más, nagy nyelvű kultúra hatott: a flamandra föként a német, az izraelire pedig a német mellett az orosz.

A vizsgálat tehát egy olyan többrendszer-elméleti keretben történik, mely az irodalmi rendszeren kívüli (társ)rendszereket is bevonja a vizsgálatba. Ezek nélkül a fordítások magyar irodalombeli fogadtatása nem írható le adekvátan. Ennek tulajdonítható, hogy e könyv több területet is átfog: a kapcsolat- és eszmetörténettől az irodalomtörténeten át a fordításelméletig.

Munkámban a következő fogalmakat használom: többrendszer, központ, periféria, finnugor háló, újraírás, forráskultúra - és ehhez kapcsolódóan forrásszöveg, forrásnyelv; célkultúra - célszövegek, célnyelv. Forráskultúrán a finnt, célkultúrán pedig a magyart értem. A többiről bővebben a következőkben lesz szó. 


\subsection{Az elméleti keretről}

\subsubsection{A többrendszerüség elmélete}

A többrendszerüség ${ }^{4}$ fogalmát Even-Zohar vezette be, és a szocio-kulturális rendszerek összességét jelenti, mely rendszerek egymással szoros kapcsolatban vannak. Ezek egyik részrendszere az irodalmi rendszer, mely egyszerre független és függő a többrendszerben közreműködő más részrendszerektől. A többrendszerűség elméletének kidolgozásával annak a megmagyarázásra tett kísérletet, hogyan müködnek az írott szövegek egy adott kultúrában. Többek között azt vizsgálta, hogyan válhatnak a nem kanonizált szövegek kanonizáltakká. Azt, hogy mely művek kerülhetnek be a kánonba, a centrum/központ határozza meg. Természetesen maga a centrum sem egységes, homogén. Azok a csoportok, szereplők, amelyek alkotják - a termelők, kritikusok, kiadók, folyóiratok, klubok, írócsoportok, kormányzati testületek, oktatási intézmények, a tömegtájékoztatás különféle csatornái stb. - különböző elvek mentén vesznek részt a kánonalkotásban. A centrum köré csoportosulnak a perifériák a nem kanonizált műveikkel, melyek a központba kerülésért, a kanonizálttá válásért harcolnak. A fordított irodalmat általában a perifériához tartozónak gondolták el. Ha a forrásszöveg éppen kanonizáltsága miatt került kiválasztásra, a célnyelvü kultúrában immár célnyelven megjelenő szövegre csupán mint az „eredetit” megmutatóra tekintettek. Even-Zohar kimutatta azonban, hogy a fordított szövegek centrális vagy periférikus mivolta ennél bonyolultabb kérdés, hogy a fordítások különbözőképpen müködnek az adott többrendszer életkorától, erősségétől és stabilitásától függően. A nagyobb, régibb többrendszerekben, mint az angolszász vagy francia, a fordítás leginkább periférikus - a krízishelyzeteket kivéve, míg a kisebb, alacsony vagy fiatal $(\mathrm{abb})$ többrendszerek esetében a fordítás központi helyet foglalhat el. Bennünket témánk szempontjából leginkább ez utóbbi érdekel, hiszen mind a finn, mind a magyar irodalmi rendszer az európai makrotöbbrendszer felől nézve periférikusnak tekinthető.

\subsubsection{Mi a fordítás?}

A címben megfogalmazott kérdésre a már korábban leírtak függvényében egyszerűnek tünik válaszolni: a fordítás egy forrásszöveg újrafogalmazását jelenti célszöveggé. Munkámban Even-Zohar értelmezését követem, miszerint csakis az interlingvális átvitel tekinthető fordításnak. Az intralingvális - finn nyelven íródott - átviteleket nem tekintem annak. A

\footnotetext{
${ }^{4}$ Angolul polysystem, magyarra még összetett rendszernek is fordítják.
} 
teljes magyar Kalevala-fordítások lehetnek egymás intralingvális átvitelei is akár, de ezzel a kérdéssel csak az egymáshoz való viszonyulásuk szempontjából foglalkozom. A fordítás (nyelv)filozófiai aspektusait, azaz hogy lehetséges-e egyáltalán fordítás, nem érintem. Azokat a múveket tekintem tehát interlingvális átvitelnek, azaz fordításnak, melyek magyarul Kalevala címmel jelentek meg, és amelyekben Barna Ferdinánd, Vikár Béla, Nagy Kálmán, Rácz István és Szente Imre neve fordítóként szerepel.

Ugyanakkor elfogadom Andre Lefevere megközelítését, aki a fordítást az újraírás egyik fajtájának tekinti a kritika, az antológiába szerkesztés stb. mellett. ${ }^{5}$ Lefevere azt vizsgálta, hogy az újraírás hogyan és milyen mértékben manipulálja - múvészileg és ideologikusan is akár - az irodalmi múveket. Amikor a Kalevala teljes magyar fordításainak fogadtatását tárgyalom, akkor tulajdonképpen abból indulok ki, hogy ezek az átültetések a finn Kalevala újraírásai. Hiszen mindegyik fordító a maga intencióival és fordítási stratégiáival egy többé-kevésbé jól behatárolható közönség számára alakította saját szövegét.

Visszatérve ahhoz a kérdéshez, hogy miért pont a többrendszerüségelméletét választottam a vizsgálat keretéül: a többrendszer és a hagyományos fordításelméletek között fennálló - fordítással szembeni - viszonyulásban tetten érhető különbségnek tulajdonítható. Míg a hagyományos fordításelméletek a fordító szubjektív képességében hittek, mely a fordítási folyamatot irányítja egy, a forrásszöveggel ekvivalens célszöveg létrehozásában, mely célszöveg a célkultúra konvencióira hat, addig a többrendszer elmélete - éppen ellenkezőleg - azt állítja, hogy a befogadó vagy célkultúra sokkal meghatározóbban irányítja a fordító esztétikai előfeltevéseit, ezen keresztül pedig a fordítói stratégiákat és döntéseket, mint azt gondolnánk.

Ez egyike azoknak a megközelítésmódoknak, mely a fordítás kérdését és problematikáját a kultúra kérdéskörén keresztül, azon belül vizsgálja. A fordításokhoz célközpontúan, leíró szempontból közelít, vagyis nem a preskriptivitásra, az eloórásra helyezi a hangsúlyt, hanem a leírásra. Célja nem az adott célszöveg és forrásszöveg összehasonlító vizsgálata, hanem a fordítás elhelyezése a célkultúrában.

\subsubsection{A leíró (deskriptív) fordítástudomány}

A deskriptív megközelítés kidolgozója Gideon Toury. Kutatásait héberre fordított szövegek vizsgálatával kezdte, és arra a következtetésre jutott, hogy a fordítandó művek/szövegek kiválasztása nem feltétlenül esztétikai, hanem sokkal inkább ideológiai indokokkal magyarázható. Toury

${ }^{5}$ Vö. LEFEVERE 1992 
figyelme azok felé a nyelvi, irodalmi, társadalmi stb. tényezők felé fordult, melyek szerinte irányíthatják a fordítás folyamatát.

Ilyen tényező például a fordítási politika, mely azokat az eljárásokat vizsgálja, melyek egy szöveg kiválasztására vonatkoznak egy adott kultúrából, egy adott időpontban. Feltételezésem szerint a Kalevala lefordítását a 19. században egyfelől a rokonnyelviség, másfelől pedig a finn eposz hirtelen központba kerülése is indokolta. Ehhez járult még hozzá az első fordító(k) azon szándéka is, hogy átültetésükkel a hiányzó magyar népeposzt pótolják, a célirodalom rendszerében meglévő űrt fordításaikkal kitöltsék. A fordítási politika kérdéséhez tartozik a közvetítő nyelv használata és az ehhez való viszonyulás is: megengedett-e, bevallja-e, bevallhatja-e a fordító, valamint melyek azok a nyelvek, melyek egy adott kultúrában közvetítő nyelvként elfogadottak. Ugyancsak a fordítást befolyásoló tényezők közé sorolja az elméleti és kritikai megjegyzéseket, mint például az adott korban uralkodó előíró fordításelméleteket, a fordítói előszavakat, múhelytanulmányokat, kiadói, szerkesztői előszavakat. Magát a fordított szöveget pedig a legfontosabb forrásnak tartja ezeknek a tényezőknek a leírásában, hiszen célszövegekből válnak kiolvashatóvá azok a fordítói magatartások, intenciók, melyek a fordítás folyamatában hatottak.

Ami a jó és rossz fordításokat illeti, Toury megfelelő és nem-megfelelő fordításokról beszél, de nem a forrásszöveg viszonylatában. Hiszen a célszöveg nem más, mint a célkultúrában jelen levő, a forrásszöveget helyettesítő kulturális tárgy. Innen szemlélve pedig nincs relevanciája a célszöveg „jó" vagy „rossz" megoldásai vizsgálatának. Első látásra talán meghökkentőnek tünik Toury gondolata, de be kell látnunk, hogy például a magyar Kalevala-fordítások esetében sem attól vált egyik vagy másik Kalevala-átültetés elfogadottá a célkultúrában, mert a fordító esetleg olyan nyelvi megoldásokat alkalmazott, melyek megfeleltek a forrásszöveg támasztotta követelményeknek, hanem mert a célkultúra elvárásainak megfeleltek. Ahhoz azonban, hogy a fordítói stratégiákat adekvátabban leírhassuk, a forrásszöveggel való egybevetés is megkerülhetetlenné válik. Emellett pedig szakolvasóként éppen a forrásnyelv, a finn ismeretéből kifolyólag sem tudunk eltekinteni az összevetéstől. Célunk azonban nem annak megállapítása, hogy jó-rossz fordításokról van-e szó, hiszen a különböző fordítások létrejötte és a kutatás időpontja között eltelt idő olyan változásokat eredményezett a célkultúra többrendszerében, melyek megakadályozzák, hogy a célszövegeket a forrásszöveggel való összevetésükben jónak vagy rossznak minősítsük. A szövegek összevetése releváns részét képezi a célszövegek vizsgálatának munkámban is, de eszközként és nem célként szolgál. A cél- és forrásszöveg nyelvészeti alapú összevetéséből a stratégiákat érintő hipotéziseket állíthatunk fel. Azonban végig 
szem előtt tartjuk, hogy a fordítás nem más, mint a fordítói stratégiák produktuma, és amint már említettem, ezeket mindenekelőtt a célrendszer domináns normái és modelljei határozzák meg.

\subsubsection{A finnugor háló fogalma}

Egyik írásában ${ }^{6}$ Lefevere a Kalevala angol fordításait vizsgálja. A finn eposz lefordításának kiválasztásában az analógia szerepét emeli ki: a görög minta követését a Kalevala létrehozásában. Az angol fordítások vizsgálatán keresztül pedig arra a következtetésre jut, hogy a lönnroti mintakövetést a fordítók igyekeztek kiemelni, sőt, ahol tehették, még rá is erősítettek az általa nyugatinak nevezett hálóhoz való idomításra. Nyugati hálón Lefevere szövegrendszereket ért. Olyanokat, melyek éppen az analógiából kifolyólag elfogadott és elfogadható szövegtípusok, mivel egy már központi és tekintéllyel bíró többrendszer kanonizált típusai. Ilyen pl. a klasszikus eposz mint szövegtípus, mely előírhatja és elő is írja, hogy egy másik nyelven ugyanabban a múfajban írott münek milyennek kell lennie. A szövegrendszerek mellett a hálót egy olyan fogalmi keret fogja össze, mely - ismét a klasszikus eposzok példájából kiindulva - azt írja elő, hogy egy olyan valamit, mint a „hősi kor", amikor egy eposz születhetett, hogyan is kell elképzelni. A Lefevere által használt nyugati háló mintájára bevezetem a finnugor háló fogalmát. A hálóalkotó szövegrendszerben nem a müfaj, hanem az a nyelv a meghatározó, amelyen a szövegek íródtak, a fogalmi keret pedig az egyedítés konstruálásának eszköze. Olyan identifikációs (segéd)eszköz, mely a különbségekre fókuszál, felerősíti azokat a másságokat, melyek a nyugati háló diktálta fogalmi kerettől megkülönböztetik, és azokat a hasonlóságokat, melyek a finnugor háló megteremtéséhez szükségesek lehetnek.

\subsection{A fordítások vizsgálatának módszeréről}

Könyvemben két irodalmi többrendszerrel foglalkozom: a magyarral és a finnel. Mindkét irodalmi rendszer a(z) (nyugat-)európai makrorendszerben periférikus helyet foglal el. Ennek legfőbb oka éppen a két nyelv (nyugat-európai) „,társtalanságából” adódik. Finnugor nyelvekről van szó, és ez a tény - feltételezésem szerint - túlmutat az egyszerü „két rokon nyelv"-sémán, különböző korszakokban éppen a nyelvrokonságon alapuló egymáshoz viszonyulás határozza meg a fordításokkal szembeni kö-

${ }^{6}$ LEFEVERE 1998 
zeledési módot. Hogy a rokonnyelviség mellett még milyen viszonyokat vizsgálok, azt a Jose Lamberttől kölcsönvett táblázattal ${ }^{7}$ illusztrálom:
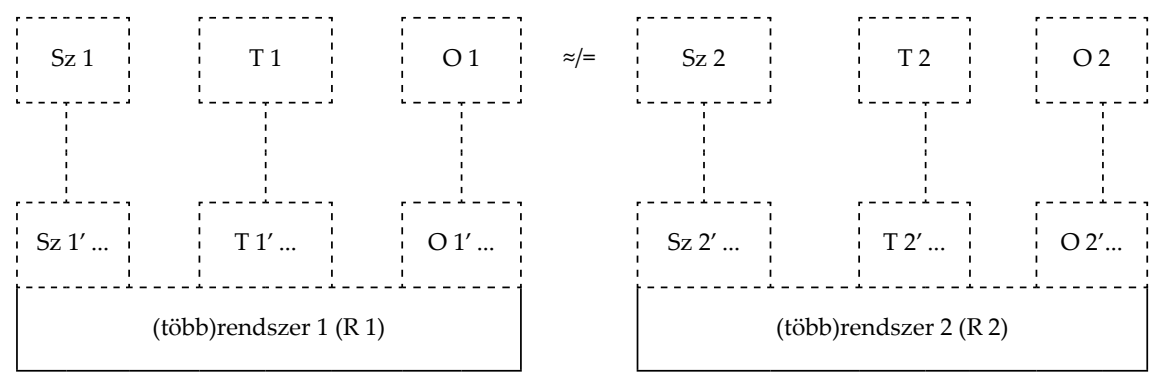

A táblázat magyarázata és alkalmazási módja:

Sz 1: a forrásszöveg szerzője (Lönnrot mint a Kalevala szerkesztője)

Sz 2: a célszöveg szerzője (a teljes fordítások szerzői, a fordítók)

T 1: a forrásszöveg (a Kalevala 1849-es kiadása)

$\mathrm{T}$ 2: a célszöveg (a magyar fordításkiadások)

O 1: a forráskultúra olvasója/befogadója (a finn kritikai fogadtatás)

O 2: a célkultúra olvasója/befogadója (a fordítások magyar kritikai fogadtatása)

Sz 1', T 1', O 1': a forráskultúra szerzőit, szövegeit, olvasóit/befogadóit jelöli (általánosan a finn többrendszerről, a forrásszöveg helyéről a finn irodalmi rendszerben)

Sz 2', T 2', O 2': a célkultúra szerzőit, szövegeit, olvasóit/befogadóit jelöli (általánosan a magyar többrendszerről, a finn irodalomból fordított múvek helyéröl a magyar irodalmi rendszerben)

A szaggatott vonalak a kapcsolatok komplex és dinamikus voltát jelölik. $\approx /=$ : a két rendszer (R 1 és $\mathrm{R} 2$ ) közötti kapcsolat nyílt voltára utal, mely kapcsolat természete függ a fordítói viselkedéstől, a fordító alkalmazta stratégiáktól, s melynek természete a célkultúra normái felől vizsgálható.

A továbbiakban az a feladatunk, hogy kiválasszuk azokat a kapcsolatokat és viszonyokat, melyek a két rendszer egymáshoz való viszonyáról legtöbbet elmondanak. A már említett finnugor nyelvrokonság mellett a magyar-finn kapcsolatok bizonyulnak meghatározónak, és hatással vannak a finn eposz magyar fogadtatására is. Erről fog szólni a második fejezet.

${ }^{7}$ LAMBERT 2006: 38. 
A célszövegeken kívül rendelkezésünkre állnak még a fordítók mühelytanulmányai, a megjelent célszöveg mellett található elö- és utószavak, a megjelenés után született recenziók, tanulmányok, melyek támpontot adtak a vizsgálat során. A különböző korszakokban a fordítással kapcsolatos irányelvek pedig a fordítói stratégiák megállapításában és a fogadtatás főbb vetületeinek megértésében segítenek. Ezen túlmenően pedig nemcsak a fordítás jelenségéhez füződő viszonyulásról árul el sokat, hanem magáról az irodalmi rendszerről is, annak központjáról, kanonizációs stratégiájáról és azokról az ideológiairányította stratégiákról, melyeket a központi intézmény alkalmaz a kanonizálás során. Ezekkel a viszonyokkal és kapcsolatokkal foglalkozik a harmadik és negyedik fejezet, melyek végén - az ötödik fejezet összehasonlító vizsgálata előtt - bizonyos elvárások fogalmazódnak meg. Ezekre válaszol az utolsó fejezet. 



\section{NEMZETI TÖREKVÉSEK: FINNEK ÉS MAGYAROK}

Az utókor főként nemzeti-ideológiai szempontokat érvényesítve tekint a Kalevala létrejöttének, a 19. századnak az irodalmi termésére. Mi is ezt tesszük a következőkben: azt járjuk körül, hogyan is függ össze az irodalmi rendszer a többi - társadalmi, kulturális - rendszerrel, és hogy e rendszerek összjátékaként miként is születhetett meg a Kalevala, az elemzésünk tárgyát képező forrásszöveg és annak magyar fordításai, a célszövegek.

A nemzeti romantika időszaka, a nemzetté válás folyamatának ideje az egyik legérdekesebb szakasza a finn művelődéstörténetnek. A század elején a Finnországot érintő politikai változás - a Svéd Királyság egyik provinciájából az Orosz Birodalom autonóm nagyhercegségévé vált - a finneket saját identitásuk, a finnség fogalmának pontosabb meghatározására késztette.

A Kalevala nemzetiöntudat-formáló szerepéről két tényezőn - a nyelven és a történelmen - keresztül beszélhetünk. Az eposz, amint e munkában is rámutatok, egyrészt a finn nyelvet legitimizálta azáltal, hogy bebizonyította: létre lehet hozni értékes alkotásokat finn nyelven is. Másrészt pedig a korabeli értelmezésében érvényesített történelmi vagy mitológiai szempont a münek a finn nép (ős)történetét létrehozó szerepére mutatott rá. A Kalevala tehát az 1810-es években felvetődött nyelvvel, történelemmel és irodalommal kapcsolatos kérdésekre adott választ. Ahogyan ezt a közelmúltban Hannele Dufva is megfogalmazta: „a Kalevala és a Kanteletár runóival a finnek megértették, hogy a lenézett finn nyelven igenis létezett tekintélyes terjedelmű eredeti költészet. Így teremtődött meg és épült fel a közös múlt, a finn nemzetség történelme." ${ }^{8}$

\footnotetext{
${ }^{8}$ [eredeti szöveg:] „Kalevalan ja Kantelettaren runojen myötä suomalaiset alkoivat ymmärtää, että halveksitulla suomen kielellä olikin olemassa mittava määrä omaperäistä runoutta. Näin luotiin ja rakennettiin yhteistä menneisyyttä, Suomen suvun historiaa." [fordítás tőlem, V. P. I.] LAIHIALA-KANKAINEN - PIETIKÄINEN - DUFVA 2002: 29.
} 
A magyar, vagyis a célkultúra többrendszerének áttekintésekor a nemzeti nagyelbeszélés kérdését járjuk körül. Feltételezésem szerint a Kalevala magyarra fordításának kiválasztásában ennek döntő szerepe volt. A magyar többrendszer e szeletének bemutatását főként a kortárs, 19. századi irodalomtörténettel foglalkozók munkáira támaszkodva teszem. Gondolok itt többek között Dávidházi Péterre, Imre Lászlóra, Szajbély Mihályra és S. Varga Pálra.

Ugyancsak itt lesz szó a magyar és a finn nyelv finnugor nyelvcsaládba tartozásának a nemzeti identitás konstruálásában játszott szerepéról, valamint a 19. század végének és a 20. század első harmadának magyarfinn kapcsolatairól. A finn eposz ugyanis, sokszor éppen a fordításokon keresztül, meghatározó szerepet játszott e kapcsolatok kialakításában és fenntartásában,. Ezek a kapcsolatok ugyanakkor a fordításokra is hatottak: megjelenésüket éppen e kapcsolatok élő mivoltának köszönhetik.

\subsection{Finnország a 19. században}

A finn nemzeti identitás kialakulása és Finnország független állammá válása két szinten történt: először a konkrét cselekvés szintjén, hogy Finnország politikailag és gazdaságilag autonómmá váljék, másodszor pedig a kulturális dialóguson keresztül, ahol körvonalazódott a finnek elgondolása önmagukról, arról, mit is jelent finnek lenni, történelmükről, valamint más nemzetekhez való viszonyukról.

Lássuk először részletesebben Finnország történelmi helyzetét az 1917es függetlenné válásig.

\subsubsection{Történelmi háttér ${ }^{9}$}

Finnország államiságának kialakulásában két kulcsfontosságú időpontról lehet beszélni: 1809-ről és 1917-ről. Független állammá 1917-ben vált, de Matti Klinge véleménye szerint finn államról 1809 óta beszélhetünk. ${ }^{10}$ Ekkor vált ugyanis Finnország a Svéd Királyság egyik provinciá-

\footnotetext{
${ }^{9}$ A történelmi háttér felvázolásához KLINGE 1993 és JUTIKKALA - PIRINEN 1996 könyveket használtam fel.

${ }^{10} \mathrm{Az}$ 1809-es év a finn államiság kialakulásában Klingén kívül több kutató szerint is meghatározó. Päiviö Tommila legfőbb érve például éppen a Haminai békeszerződés szövegén alapul. A Svéd Királyság és az Orosz Cári Birodalom között köttetett békeszerződésben ugyanis a svéd fél nem egy egységes, Suomi nevü területről mond le a cár javára, hanem pontosan megnevezett kisebb egységekről: „Kymenkartanon lääni, Uudenmaan ja Hämeen, Turun ja Porin mukaan lukien Ahvenanmaan saaret, Savon ja Karjalan, Vaasan ja Oulun lääni" http://www.histdoc.net/historia/frhamn.html Letöltve 2008. szeptember 12. Az orosz cári
} 
jából az Orosz Cári Birodalom autonóm nagyhercegségévé. Ez az év nem csupán az I. Sándor cár kijelentése okán - melyben elismerte a finnt mint külön nemzetet ${ }^{11}$ - jelentett fordulópontot. Erre az időszakra tehető Finnország tágabb földrajzi felfogásának a megszilárdulása is. Az ezt megelőző századokban, különösen az 1700-as években, e terület a svéd és orosz terjeszkedési politikán alapuló ellentétek harctere volt. Amit akkor finn földnek (=Suomi) tekintettek, az a mai Finnország délnyugati része (=VarsinaisSuomi - Tulajdonképpeni-Finnország). 1809 után - gyakorlatilag 1812-től, egy meglepő cári döntés folytán - viszont magába foglalta keleti oldalon a mai Orosz-Karjala egy részét és Viipurit, ${ }^{12}$ nyugaton a Botteni-öbölig terjedő területet, délnyugaton pedig az Ahvenanmaa-szigetcsoportot. A határok ily módon való rögzítése jól szemlélteti az Orosz Birodalom védelmi célokat szolgáló terjeszkedési politikáját. Hiszen az említett szigetcsoport mai napig megmaradt svéd nyelvűnek, míg a finn nyelvü Osthrobotniára az Orosz Birodalom nem tartott igényt. Az új értelemben vett "finn föld" területén az évszázados svéd uralom következtében meghatározó volt a svéd nyelvű lakosság száma. Tulajdonképpen ők alkották a finn arisztokráciát és a finn nagypolgárságot is. A többség anyanyelve azonban a finn volt.

Az orosz uralom első évtizedeiben az autonóm státusz saját parlamentet, szenátust, közigazgatást, hadsereget és pénznemet jelentett. Hivatalos nyelvnek azonban megmaradt a svéd. A nagyhercegség élén a cár állt, akit egy főkormányzó képviselt, és akinek joga volt felülbírálni a szenátus minden döntését.

Az 1830-as években épült ki és vált valóságos közigazgatási és szellemi központtá az 1812-ben fővárossá nyilvánított Helsinki. Az addigi központ a földrajzilag Stockholmhoz közel eső Turku volt. Az 1640-től működő turkui egyetemet az 1827-es tüzvész után helyezték át Helsinkibe.

Az új birodalmi résznek biztosított (viszonylagos) autonómiának és II. Sándor cár trónra kerülésének köszönhetően az 1860-as években fejlődésnek indult az addig elmaradott terület. Utakat, vasutakat építettek: Helsinki és Hämeenlinna, valamint Helsinki és Szentpétervár között. A fejlődés II. Sándor cár uralkodása alatt érte el csúcspontját. 1858-ban megnyílt az első finn nyelvű középiskola Jyväskyläben, 1863-ban pedig a cár által öszszehívott rendi országgyülésen elfogadtak egy új nyelvtörvényt, mely a

birodalmon belül azonban ezeknek a kisebb egységeknek az összessége nyeri el az autonóm státuszt. Vö. TOMMILA 1989: 49-65.

${ }^{11}$ I. Sándor cár 1809-es, porvoói országgyűlés előtti beszédéből: „placé desormais au rang des nations" id. LAITINEN 1981b: 117.

${ }^{12}$ Ezek azok a területek, melyeket az Orosz Birodalom a Svéd Királyságtól már korábban elhódított. Ezeknek Finnországhoz, a Finn Nagyhercegséghez való csatolása tulajdonképpen visszacsatolás volt még akkor is, ha a nagyhercegség része volt az Orosz Birodalomnak. 
svéd mellett a finn nyelvet is hivatalossá nyilvánította. A század végére a cár halála és a belső viszályok véget vetettek az orosz reformer politika időszakának. Ez különféle megszorításokat eredményezett a finn közigazgatásban, a gazdasági és kulturális életben egyaránt. Az 1899-es „februári manifesztum" pedig gyakorlatilag az autonóm státusz megszűnését jelentette. Megszűnt a szenátus Finnországot érintő ügyekben hozott döntési joga: a cár, II. Miklós, teljhatalmú uralkodóvá vált. A manifesztum célja a finn nagyhercegségnek az Orosz Birodalomba való teljes beolvasztása volt. Bár a századfordulón a társadalmi osztálykülönbségek miatti elégedetlenség Finnországban is egyre inkább elharapózott, az 1905-ös általános sztrájkban a finnek egy emberként szólaltak fel a manifesztummal eltörölt jogok visszaállítása érdekében.

Az Orosz Birodalmon belüli viszályok, az egyre növekvő elégedetlenség, az I. világháború és a Birodalom szétesése megteremtette a lehetőséget arra, hogy 1917. december 6-án Finnország független állammá váljék.

\subsubsection{Finnesedési törekvések a 19. század első felében: a finn nyelvkérdés}

Az 1809-ben bekövetkezett politikai változás a kulturális életben kezdetben alig éreztette hatását. Ennek több oka is volt. Egyrészt az, hogy a 19. század elején, a Svéd Királyságtól elszakadva a kulturális élet nagyon fejletlen volt, hiányzott az intézményes kerete. Másrészt pedig az, hogy a kulturális központ továbbra is Turku maradt. Az a város, mely már a Svéd Királyságnak is egyik legfontosabb szellemi központja volt. Az egyetem akkor is Turkuban maradt, amikor Helsinki az 1812-es fővárossá nyilvánítás után a nagyhercegség gazdasági, közigazgatási központjává vált. A kulturális életben tulajdonképpen 1827-ben következett be valódi változás, amikor a turkui tüzvész után az egyetemet is Helsinkibe költöztették. Ezzel Turku elvesztette kulturális központ jellegét. A változás ugyanakkor folytonosságot is jelentett: a Turkuban megszúnt egyetem legtöbb tanára Helsinkiben folytatta munkáját, és az az értelmiségi réteg, mely az 1830-as és az azt követő évtizedekben Helsinkiben tevékenykedett, a Turkui Egyetemen tanult vagy ott kezdte tanulmányait. Így azok a finnesedési törekvések, melyek az 1810-es években Turkuból indultak el, az 1830-as években, valamint a század második felében Helsinkiben teljesedtek ki.

Az 1809 és 1827-1828 között Turkuban tevékenykedő, többnyire svéd nyelvű értelmiségiekből álló csoport, amelyet ma "turkui romantikusokként" tartanak számon, három feladatot tüzött ki maga elé: történelmet, nyelvet és irodalmat adni a finn nyelvü többségnek. E gondolat alapjául Herder nemzetfelfogása szolgált. A herderi kultúrnemzet fogalmából ki- 
indulva a turkui romantikusok fő célja egy kulturális szempontból fejlett nemzet kialakítása volt, még akkor is, ha ennek megvalósíthatóságához éppen a finn nyelv helyzete miatt meglehetős kétkedéssel viszonyultak. A turkui romantikusokra Herder mellett leginkább az ugyancsak német Schelling filozófiája hatott, ezen belül pedig a mitológiáról vallott felfogása. Eszerint egy nép legősibb mitológiájában megtalálható a nyelv és a kultúra a maga eredeti tisztaságában, romlatlanságában. Erre alapozva, és arra a hitre, hogy a finnek Skandinávia egyik legrégebbi népcsoportja, a svédországi svéd romantikusok is meglehetős érdeklődéssel fordultak a finn népköltészet felé. A turkui romantikusok sok tekintetben éppen a svédországiak hatására kezdtek érdeklődni a finn népköltészet iránt. Az egyéni sajátosságokat a népköltészetben vélték felfedezni. Az elkezdett népköltészeti gyưjitések kettős feladatot szolgáltak: mivel a gyưjtött anyagok a nép nyelvén szólaltak meg - a finn nyelv fejlesztésének alapját képezték és a népi lelket tükrözték. Ez utóbbi pedig az egyéni sajátosságokra irányította a figyelmet.

A politikai változás a svéd nyelvű értelmiség számára elsősorban nem etnikai, hanem kulturális dilemmát jelentett, és később, majd csak a század második felében politikait: a svéd kultúrától elszakítva hirtelen légüres térben találta magát. Olyasvalaminek kellett tartalmat adnia, amit Finnország autonóm státusza, és az ezáltal felkínált lehetőség nyújtott. Ez pedig az Adolf Ivar Arwidssonnak ${ }^{13}$ tulajdonított kijelentésben fogalmazódott meg talán először: „Már nem vagyunk svédek, oroszokká nem akarunk válni, legyünk hát finnek!"14 Egy 20. századi kutató, Risto Alapuro, a „már nem vagyunk svédek” és az „oroszokká nem akarunk válni” hozzáállásban az 1809-ig hatalmon levő svéd nyelvű elit hatalommegtartó törekvéseit véli felfedezni. ${ }^{15} \mathrm{Az}$ orosz uralom kezdetéig ugyanis a svédek gyakorlatilag azonosak voltak a hatalommal, 1809 után azonban a hatalom megtartása érdekében az államot jelentő autonóm Finn Nagyhercegséggel kellett azonosulniuk, az autonóm egység megtartását kellett szem előtt tartaniuk. Erre pedig az integrálódás útját tartották a legalkalmasabbnak: integrálódást a többségbe, a finn nyelvet beszélők közösségébe. A „legyünk finnek" felszólítás ösztönzést jelentett az értelmiség számára egy új, finn nyelvü kultúra kialakítására, ezen keresztül és ezzel párhuzamosan pedig a finn nyelv hivatalossá tételére. A finn nyelv hivatalossá, a svéddel egyen-

\footnotetext{
${ }^{13}$ Adolf Ivar Arwidsson (1791-1858) a Turkui Egyetem tanára volt 1822-ig, amikor elbocsátották állásából radikális politikai nézetei miatt. Elbocsátása után Svédországba emigrált.

14 "Ruotsalaisia emme enää ole, venäläisiksi emme tahdo tulla, olkaamme siis suomalaisia!" Állítólag Snellman volt az, aki Arwidssonnak tulajdonította ezt a szállóigét, miközben a finn ügyekkel foglalkozó bizottság (Suomen asiain komitea) egyik tagja, G. M. Armfelt (1757-1814) köreiben már korábban szállóigévé vált. Vö. TOMMILA 1989: 54.

${ }^{15}$ Lásd ALAPURO 1987 és 1999.
} 
rangúvá tétele a hatalom megszilárdításának legfontosabb eszközévé vált. Az első, finn nyelvkérdéssel kapcsolatos írások az 1810-es években kezdtek megjelenni. Bár nyelvezetüket a népnemzeti romantika stílusa hatotta át, tartalmilag idealizmustól mentes tényszerúség jellemezte őket. Erről tanúskodnak a J. J. Tengströmnek és J. G. Linsénnek az Aura és Mnemosyne folyóiratokban publikált írásai. ${ }^{16} \mathrm{~A}$ finn nyelv fejlesztését és státuszának hivatalossá válását támogatókat fennománoknak nevezték.

A nyelvkérdés legradikálisabb képviselője éppen A. I. Arwidsson volt. Az 1821-ben indított Åbo Morgonblad hasábjain, majd az ennek betiltása után megjelentetett Oskyldigt ingenting címü lapban állandóan jelen voltak a finn nyelv korabeli és remélt jövőbeni helyzetével foglalkozó írások. Egyik cikkének végén ez áll: „Milyen boldognak éreznénk magunkat, ha prófétai előrelátással megjósolhatnánk a finn nyelv és irodalom gyors fejlődését kultúránkban. Legalább feltételesen megtehetnénk. Ha a nemzet tagjai összefognak, hogy szilárd elhatározással elismerjék a nemzeti nyelvünket megillető természetes jogokat, és ha a forró nemzeti lelkesedés felismeri, melyek az erre legmegfelelöbb eszközök, ha okosan és hathatósan használják ezeket, akkor új korszak kezdődik: a megbecsülésre méltó finn nyelv fiatal finn irodalommá bimbózásának/virágzásának a korszaka, mely a legszentebb gyümölcsöt termi, akárcsak Finnország megművelt földjei." ${ }^{17}$ A finn nyelv alkalmassá tétele a tudományos, múvészi és hétköznapi kommunikációra tudatos fejlesztést igényelt. Ennek előtérbe helyezése azoknak a mélyebb összefüggéseknek a megértésére és átlátására vall, miszerint nyelv nélkül nincs írott kultúra, írott kultúra nélkül pedig nincsen nemzet.

\footnotetext{
${ }^{16}$ Erre a tényszerüségre és tudatosságra mutat rá Pusztay János is a finn nyelv helyzetéről szóló tanulmányában: „Reális helyzetfelismerést tükröz, hogy a század első felében a finn nyelv állapotának és fejlesztési lehetőségeinek kérdésére helyezték [finnországi értelmiségiek] a hangsúlyt, s csak a század közepétől erősödött fel az az igény, hogy a finn nyelv kapjon hivatalos státuszt." PUSZTAY 2001: 58.

${ }^{17}$ [eredeti szöveg:] „Miten onnellisiksi tuntisimmekaan itsemme, jos kykenisimme profeetallisella äänellä ennustamaan suomen kielen ja kirjallisuuden edistyvän kulttuurissamme ripeästi. Ainakin ehdollisesti voimme sen tehdä. Jos kansakunnan jäsenet yhdistyvät lujan päättäväisesti hyväksymään kansalliskielemme jälleen luonnollisiin oikeuksiinsa ja lämmin kansallinen innostus oivaltaa siihen sopivimmat keinot ja käyttää niitä viisasti ja voimaperäisesti, silloin alkaa uusi aikakausi: suomen kunnianarvoisa kieli puhkeaa nuoreksi suomalaiseksi kirjallisuudeksi ja kantaa Suomen viljeltyjen peltojen tavoin mitä siunatuinta hedelmää." [fordítás tőlem, V. P. I.] Idézi VARPIO - HUHTALA 1999: 187.
} 


\subsubsection{A történelem, nyelv és irodalom szerepe a nemzetté válás folyamatában}

A „turkui romantikusok" által kitűzött hármas cél az 1830-as években és az azt követő évtizedekben a "helsinki romantikusok" tevékenysége révén teljesedett ki. Ebbe a körbe tartozott többek között Elias Lönnrot (1802-1884) - a Kalevala alkotója, Johan Vilhelm Snellman (1801-1881) - a svéd és finn nyelven író filozófus és irodalomteoretikus és Johan Ludvig Runeberg (1804-1877) - az első finn nemzeti költő is.

Az egyetem Helsinkibe költöztetése után a Turkuban létrejött rövid életü Selma-Társaság (Selma-liitto) vagy Aurora-kör (Aurora-Seura) Helsinkiben Szombat-Társaságként (Lauantaiseura) szerveződött újra, majd 1831. február 16-án intézményes formát öltött: megalakult a Finn Irodalmi Társaság (Suomalaisen Kirjallisuuden Seura, a továbbiakban FIT). Az alapító tagok - Lönnrot, Gadolin, Gyldén, Ilmoni, Lille, Veterin, Lindfors, Nordström, Rein, Ståhlberg és Ticklén - Carl Niklas Keckmann lakásán gyültek össze. A programjukban meghirdetett célok közül a legfőbb a nemzeti irodalom előmozdítása, a finn nyelv ápolása és fejlesztése volt: „A FIT egyedüli célja, hogy előmozdítsa a hazafias irodalom gazdagítását, a finn nyelv fejlődését, hogy a finnül írt vagy Finnországgal kapcsolatos írásokat összegyüjtse, valamint, hogy a történelmi illetőleg irodalmi szempontból értékes írásokat megjelentesse."18

E célkitűzés összhangban állt Arwidsson nyelv- és nemzetfelfogásával, de korántsem volt annyira radikális. Ugyanis a gyakorlatban, a Kalevala megjelenéséig, alig volt olyan kiadvány, mely finn nyelvü lett volna. Az értelmiség egy része, bár támogatta a finn nyelv fejlesztését, magát a nyelvet nem ismerve, svédül publikált. Ugyanakkor szkeptikusan viszonyult ahhoz, hogy a finn nép valaha is az európai kultúrnépek színvonalára emelkedhet. Az értelmiség másik része pedig éppen ellenkezőleg: csodálta a népet, és hitt a finn nép elhivatottságában. Már a svéd uralom idején elterjedt az a gondolat, hogy a népi kultúrában rejlő gazdagság egy nép fejlettségi fokának a bizonyítéka. A főleg Henrik Gabriel Porthantól ${ }^{19}$ származó gondolatot tovább fejlesztve a romantika értelmisége a népköltészet epikus és lírai dalaiban az ősi finn nyelv kincsesházát vélte felfedezni. Úgy

\footnotetext{
${ }^{18}$ [eredeti szöveg:] „Suomalaisen Kirjallisuuden Seuran ainoana tarkoituksena on edistää isänmaallisen kirjallisuuden vaurastuttamista, Suomen kielen kehittämistä ja suomeksi sepitettyjen tai Suomea koskevien kirjoitusten kokoaminen sekä historiallisesti eli kirjallisesti hyödyllisten kirjoitusten tai kirjojen julkaiseminen." [fordítás tőlem, V. P. I.] HIRVONEN MAKKONEN - NYBONDAS 1981: 50.

${ }^{19}$ H. G. Porthan (1739-1804) a felvilágosodás korának jelentős képviselője Finnországban. A Turkui Egyetem tanára. Ôt tartják a „finn történelem atyjának”.
} 
vélték, ha a nép nyelve történetek elmesélésére és érzelmek kifejezésére alkalmas, akkor megvan az alap, melyre fejlesztését építeni lehet.

A népköltészet-nyelv-nép viszonyáról Lönnrot a Kanteletár előszavában ír. Az előszó arról tanúskodik, hogy Lönnrot sokkal gyakorlatiasabb volt annál, semhogy a népben lakozó isteni lélek ébredésére várt volna, mint kortársai. Felfogásában a népköltészet nem csupán esztétikumával, hanem funkcionalitásával válhat a nemzeti identitás megalapozójává. A népköltészet szerinte egy olyan eszmény, melyet a költőknek mindig szem előtt kell tartaniuk, ugyanakkor olyan alap, melyet át lehet és kell emelni a müköltészetbe.

A finn nyelvkérdésben Lönnrot a mérsékelt álláspontot képviselte. A FIT elnökeként, a Társaság 25. évfordulóján elhangzott svéd nyelvü beszédben, a finn nyelv használatáról a Társaság gyưlésein az 1850-es években a következőképpen nyilatkozott: „Biztos vagyok abban, hogy ha a FIT például a mai nap folyamán hirtelen felbuzdulva elhatározná, hogy ezentúl az összejöveteleken túlnyomó részben a finn nyelvet használja, akkor egy ilyen határozat rögtön érvényét is veszítené. Egy ilyen határozat - véleményem szerint - csak abban az esetben állná meg a helyét, ha ugyanakkor bevezetnők, hogy svédül egy szó sem hangozhat el. Azonban egy ilyen döntés száműzné a FIT-ből mindazokat, akik nem beszélik a finn nyelvet." ${ }^{20}$ A finn nyelv végül 1861-től lett a FIT hivatalos nyelve a svéd mellett.

Az 1800-as évek elejének arwidssoni radikális nyelvpolitikai nézetei Johan Vilhelm Snellman munkáiban kaptak nyilvánosságot. Snellman a Helsinki egyetem filozófiatanára volt, azonban 1840-ben távoznia kellett az egyetemről. Rövid németországi és svédországi tartózkodása után visszatért Finnországba, és a kuopiói iskola igazgatójaként tevékenykedett. Kuopióban három újságot is útnak indított: a svéd nyelvü Saima (1841-1846), a Litteraturblad (1847-1863) és a finn nyelvü Maamiehen ystävä (1844-1855) címü lapokat. A Saima címü újságban sorra jelentek meg cikkei, melyben a nyelv szerepét hangsúlyozta a nemzetté válás folyamatában. A nyelvvel és irodalommal kapcsolatos írásai a Saima című lap beszüntetése után a Litteraturblad című lapban jelentek meg. Snellman felfogásában a nyelv és ezen keresztül a nemzeti irodalom mint a nemzeti identitás megalapozója az egész finn társadalmat érintő szükségkérdéssé vált. A nemzeti iroda-

\footnotetext{
${ }^{20}$ [eredeti szöveg finn fordítása:] „Pidän varmana, että jos seura esim. tänä päivänä äkillisestä innostuksesta johtuisi päättämään käyvänsä keskustelua tästä lähin pääasallisesti suomen kielellä, niin tällainen päätös kumoutuisi heti. Päätös pysyisi luullakseni voimassa vain siinä tapauksessa, jos samalla määrättäisiin, ettei seuran kokouksissa saisi kuulua ruotsin sanaakaan. Mutta sellaisella päätöksellä seura karkottaisi yhteydestään kaikki ne, jotka eivät puhu suomea." [fordítás tőlem, V. P. I.] HIRVONEN - MAKKONEN - NYBONDAS 1981: 76.
} 
lom fogalmát, kritériumait a szellemi művelődés-anyanyelv viszonyából kiindulva is ő határozta meg. Ezt Kai Laitinen a következőképpen foglalja össze: „1. a nemzeti irodalom a nemzet anyanyelvén íródik, 2 . a nemzetre jellemző szellemi fejlődést juttat kifejezésre, 3. a nemzeti tudatot tükrözi, 4. példáival hat a nemzetre és 5. fenntartja a nemzeti szellemet, melyből született; egyben az egész kultúra előfeltétele." ${ }^{21}$ Snellman felfogásában és ezzel csatlakozott a kulturális fennománok ${ }^{22}$ táborához - a nyelv és ezen keresztül a nemzeti irodalom mint a nemzeti identitás megalapozója, az egész társadalmat érintő kérdéssé vált. Egyik 1844-ben megjelent cikkében így ír: „Azt gondolhatnók: egyik nyelv olyan, mint a másik, csupán különböző módon mondják el ugyanazokat a gondolatokat. Csakhogy az ember szavaival nem csupán gondolatait mondhatja el, hanem hisz és érez, tud és akar, gondolatvilága, egész szellemi lénye nyelvében él és mozog. Hogyan fejezhetné hát ki magát a nemzet szellemisége más nyelven, mint sajátján?" 23

Snellman 1856-ban, I. Miklós cár halála és II. Sándor cár trónra kerülése után, ismét az egyetem filozófiaprofesszora lesz, majd 1863-tól szenátor is. A fél évszázados szünet után újra összehívott országgyűlésen szenátorként lépett fel a finn nyelv hivatalossá nyilvánítása érdekében. 1863-ban meg is született a finn nyelvtörvény, mely a finnt a svéddel egyenrangúnak nyilvánította.

\subsubsection{A finn nemzettudat és a nyelvrokonsághoz való finn viszonyulás}

A nemzeti törekvéseknek kitünő táptalaja volt a században egyre elterjedtebbé és nyelvészetileg bizonyítottabbá váló finn-magyar nyelvrokonság gondolata. Az okok közül - éppen a svédtől való elhatárolódásból fakadóan - az európai pánnacionalizmust emelhetjük ki. A finnugor népek összefogásának szükségességét hirdető gondolat (heimoaate) egyfajta válaszként fogalmazódott meg a pángermánizmus skandináv változatának és a pánszlávizmusnak létrejöttére. ${ }^{24}$

\footnotetext{
${ }^{21}$ LAITINEN 1981b: 147.

${ }^{22}$ A fennomán mozgalom kulturálisból fokozatosan vált nacionalista politikai irányzattá a 19. század végére, ahogyan a finn nyelvkérdés is politikaivá. A politikai fennománok vezéralakja Yrjö Sakari Yrjö-Koskinen volt. Vö. Sulkunen 2004. (Erről a mozgalomról és viszonyáról a finnugor nyelvrokonsághoz részletesebben lásd a következő részt.)

${ }^{23}$ Idézi uo. 148.

${ }^{24}$ Lásd bővebben SIHVO 2003; SZÍJ 1991: 72-88.
} 
Az eszme fejlődés- és működéstörténetét tekintve az 1840-1944 közötti időszak két korszakra osztható: 1840-től Finnország függetlenné válásáig és 1920-tól a II. világháború végéig tartó korszakokra. ${ }^{25}$

Az első szakaszban, különösen az 1870-1880 közötti időintervallumban, a fennománok számára vált rendkívüli fontosságúvá a finnugor nyelvrokonság gondolata. Ezt követően a nyelv mellett a történelmi párhuzamok kibontására is nagy hangsúlyt fektettek. A 19. század elejének és közepének kulturális fennomán ideológiáját, melynek képviselői között a korábban már említett A. I. Arwidssont és J. V. Snellmant is ott találjuk, a század végére egy politikainak is nevezhető fennomán ideológia váltotta fel. ${ }^{26}$

Az I. világháború után függetlenné vált Finnországban a területvesztések (többnyire a Szovjetunió javára) okán vált újra aktuálissá a nemzeti identitás kérdése. Az elvesztett területek lakossága a balti-finn népcsoport kisebb népei közül került ki, mint pl. a karjalai, inkeri, lív vagy vót. A finnugor rokonsági eszme mellett az ugyancsak - az I. világháborút lezáró békeszerződések nyomán - területet vesztett Magyarországgal való (kényszerü) sorsközösség ${ }^{27}$ is a magyar-finn kapcsolatok megerősödéséhez vezetett a század 20-as és 30-as éveiben.

\footnotetext{
${ }^{25}$ Lásd SZÍJ 1991.

${ }^{26}$ Ez a paradigmaváltás legfőképpen Yrjö Sakari Yrjö-Koskinen munkásságának tulajdonítható, aki a század utolsó negyedében (1874-1892) volt a FIT elnöke. Vö. SULKUNEN 2004. Ugyanakkor jól tükrözi a szemléletváltást az a tény is, hogy míg a Kalevala első kiadását évekig nem tudták eladni, az 1861-ben megjelent finn Alkotmányt pár nap alatt elkapkodták a boltokból. Egyes kutatók egyenesen eposznak nevezik az Alkotmányt. Vö. ROMMI - POHLS 1989.

${ }^{27}$ Ez pedig a Nagy-Magyarország és Nagy-Finnország (Suur-Suomi) gondolatban manifesztálódott. A finn politikai diskurzusban, ha nem is olyan intenzitással, de megjelent, különösen az AKS (Akatemian Karjala Seura, vagyis az Akadémiai Karjala Társaság) ideológiájában. Érdekes módon azonban a finnországinál nagyobb jelentőségre a Szovjetunióban tett szert. Pedig Kelet-Karjalát leszámítva a „,mindent vissza és egy kicsit ráadásnak!” jelszó csak a legszélsőségesebb csoportoknál fordult elő. Ez utóbbinak a valóságtól való teljes elrugaszkodását jól példázza a következő - állítólag svéd parasztoktól származó - levéltöredék 1881-ből: „csak svéd parasztok [vagyunk], de mégis szentül és boldogan [szerencsésen] szeretnénk csatlakozni a jövőben Nagy-Finnországhoz, amelybe beletartozna Magyarország (sic!), Észtország, Orosz-Karjala, Inkeri és különösen a Volga, az Ural [folyó] és a Káma menti krumpliföldek, valamint más keleti folyók mente." Idézi SZÍJ 1991: 79. Részben e revizionista felhangok miatt e korszak magyar-finn kapcsolatait a II. világháború végétől 1989-ig mély csend övezte, különösen magyar részről. Vö. HEIKKILÄ - KARIG 1984; DOMOKOS 1972. A korszak rehabilitációja 1989 után kezdődik el, de átfogó tanulmány a mai napig nem készült.

A revizionizmus mellett még két oka volt a hallgatásnak: a szovjetellenesség és a fasizmussal való szimpatizálás. A szovjetellenesség miatt 1945 után természetszerúleg vállalhatatlanná váltak az e korszakban született írások. A szovjetellenesség különösen a Szovjetunió területén élő finnugor népek (udmurtok, komik, marik stb.) iránt érzett felelősségérzetből fakadt. A fasizmus vádja Szíj Enikő szerint a korabeli terminológiai zưrzavarnak tulajdonítható: „az ún. nagyközönségnek szánt irodalomban - magyarul, finnül, észtül egyaránt - a rokonság
} 


\subsection{A Kalevala létrejötte}

Amikor ma a Kalevaláról beszélünk, az 1849-ben megjelent Új Kalevalát értjük alatta. Ez az a kiadás, mely ismertté tette az eposzt, és amely napjainkban is a fordítások alapját képezi. Az 1849-es kiadást (50 ének, 22 795 sor) két másik előzte meg: 1833-ban a Runógyüjtemény Väinämöinenről ${ }^{28}$ (16 ének, 5052 sor), melyet Ós-Kalevalaként is említ a szakirodalom, és 1835-ben a Régi Kalevala (32 ének, 12078 sor).

\subsubsection{Népköltészeti gyüjtések az 1700-as évek végén, az 1800-as évek elején ${ }^{29}$}

A népköltészeti anyagok gyűjtése és kiadása az 1700-as évek végén, a kora romantika idején lendült fel Finnországban. A gyüjtések hátterében az a herderi gondolat állt, miszerint a népköltészeti alkotások megismerése és összegyűjtése lehetőséget teremt egy nép számára saját gyökereinek feltárásához. A legfontosabb a gyüjtött anyagok közül H. G. Porthan De poesi fennica (A finn költészetről, 1766-1778) és Christian Ganander Mythologia fennica (Finn mitológia, 1789) címü múve. A két könyvben közölt epikus énekek fő alakja Väinämöinen volt. A későbbi gyűjtésekhez viszonyítva ezekben kevés az epikus ének. A gyüjtött anyag nagy része varázsige és imádság volt. Ganander mitológiájának jelentősége legfőképpen abban áll, hogy a következő - népköltészeti gyűjtéseket végző - generáció számára mintegy kiindulópontként szolgált. Az 1800-as évek elején jelent meg Karl Akseli Gottlund Pieniä Runoja Suomen Pojille Ratoxi (Kis runók Finnország fiai mulatságára I-II., 1818-1821) című népköltési gyűjteménye, melyet Lönnrot a Régi Kalevala szerkesztésekor felhasznált. ${ }^{30}$ A Kalevala szempontjából legnagyobb jelentősége azonban az idősebb Sakari Topelius Suomen Kansan Vanhoja Runoja ynnä myös Nykyisempiä Lauluja (A finn nép régi runói újabb dalokkal egyetemben I-V., 1822-1831) címú gyüjteményének volt. Väinö Kaukonen, 20. századi Kalevala-kutató szerint Topelius gyüjtései nélkül nem jöhetett volna létre a Kalevala, mert ő volt az, aki lejegyezve

tulajdonképpeni mibenléte elsikkadt, finnugor nyelv-, nép-, nemzet-, faj-, fajta-, vér- stb. rokonságról hallva mindenki tudta, mire, kikre gondoljon. Annak ellenére, hogy ezek az összetételek ekkor a nem-finnugor nyelvekben is többé-kevésbé egymás szinonimái voltak, s hogy ez a nem szabatos szóhasználat, terminológiai zürzavar általános, nemzetközi méretü volt, évszázados hagyományokkal rendelkezett a szük szakmai berkeken belül is, és hogy nálunk, ráadásul az egyik leglátványosabb etimológia, a vér szolgáltatta hozzá a bizonyítékot (?), a fajrokonság emlegetése adott módot a fasiszta jelző odaítélésére." SZÍJ 1991: 75.

${ }^{28}$ Lönnrot 1833-ban küldte el a kéziratot a FIT-nek, de csak 1891-ben jelent meg nyomtatásban a Kalevalan esityöt (A Kalevala előmunkálatai) címü kötetben.

${ }^{29}$ KAUKONEN 1979 alapján

${ }^{30}$ Lásd PENTIK ̈̈INEN 1999. 
az orosz-karjalaiaktól az addigi leghosszabb epikus énekeket, Lönnrot figyelmét a finn nagyhercegség határain túlra irányította.

Az 1700-as években keletkezett munkák, köztük Porthané és Gananderé, nem a gyưijtött énekek, varázsigék vagy imádságok mennyisége miatt váltak fontossá, hanem sokkal inkább a hozzájuk füzött megjegyzések, tanulmányok révén. Porthan a könyve végén levő tanulmányban felhívta a figyelmet arra, hogy az összegyüjtött énekek variációi ugyanabból a forrásból származhatnak. Úgy vélte, hogy bizonyos kritikai szabályszerüségeket követve ezek a variációk egységesíthetők. Ennek bizonyítására írta meg a vas születéséról szóló runót a variációi alapján. Porthan célja nem egy nagy, terjedelmes egység kidolgozása vagy valamiféle pogány őstörténet leírása volt. Ezt bizonyítja az a tény is, hogy a keresztény elemeket meghagyta, ami Lönnrot esetében, különösen a Régi Kalevala szerkesztésekor, egyáltalán nem mondhatni jellemzőnek.

Mindenesetre az egységesítés gondolatát mások is átvették Porthantól. K. A. Gottlund 1817-ben a Svensk-Litteratur-Tidning lapba írt Friedrich Rühs 1809-ben Németországban megjelent Finland und seine Bewohner (Finnország és lakói) című könyvéről ${ }^{31}$ kritikát, melyben a finn hősi pogány korról alkotott elméletének felvázolása mellett egy hősi eposz megteremtésének gondolatát is felvetette. ${ }^{32}$ Ebben valószínúleg közrejátszott Friedrich August Wolfnak 1795-ben megjelent Homéroszról és a homéroszi eposzokról írt könyve. Wolf a homéroszi eposzok keletkezését az írásbeliség előttre datálta. Olyan énekek sorozataként írta le őket, melyek szájhagyomány útján terjedtek és i. e. a 6. században Peiszisztratosz idején jegyeztek le. Említett múvében Wolf foglalkozott a népi és a müeposszal is, a kettő közti különbségekkel, összevetve Homérosz és Vergilius eposzait. Már Porthan is erre az elméletre építette a maga énekvariációkat egységesítő gondolatát, és ebből indul ki Gottlund is, amikor egy lehetséges finn eposzról beszélt: „Ha tehát a fiatal, a hazai múvészetet inkább szívükön viselő finn írók (mivel az öregebbekre e tekintetben aligha lehet számítani) megpróbálnák

\footnotetext{
${ }^{31}$ Rühs, könyvének történelmi részében, Väinämöinenről is ír, akit a kantele teremtőjének és nagy énekesnek tart. Ezen túlmenően pedig a finnek legnagyobb isteneként, a tűz szerzőjeként, hajóépítőként és a szellemi kultúra megalapozójaként jelenik meg. Vö. KARKAMA 2001: 246.

${ }^{32}$ Gottlund felfogásában a finneknek, mint az európai népeknek általában, volt hőskoruk. Az 1800-as években Finnországban különösen az Iliász mintája erősítette azt a felfogást, mely szerint a harc és a hősiesség rendkívüli fontossággal bír az eposzokban. Olyannyira elterjedt ez a nézet, hogy a nemzeti eposzokat a hősi eposzokkal azonosították. A nemzeti állam és identitás konstruálói a népek közötti viszony leírásában vélték meghatározónak a harc jelentőségét. A harc ugyanis - úgy vélték - az összetartozás érzését erősíti, az ellenségkép pedig előmozdítja a nemzeti identitás fejlődését. Gottlund ugyancsak itt fejti ki véleményét a finnek monoteizmusáról: egy istenük volt, akit Jumala névvel illettek, Väinämöinen, illetve Kaleva többi fiai csupán hősök, vezérek, de semmiképpen nem istenségek, aminek például Rühs is tekinti őket.
} 
ápolni, gondozni a hazai irodalmat - micsoda tér nyílna kísérletük előtt! Olyan mozzanatokat találnának, amelyet fölöslegesen keresnek a külföldi irodalomban - igen, a bíráló [Gottlund] olyan messze megy, hogy állítani meri: ha össze akarnák gyüjteni a régi népdalokat, s rendezett egészet alkotni belőlük, legyen az eposz, dráma vagy bármi, ebből új Homérosz, Osszián vagy Nibelung-ének keletkezhetnék; s a híressé vált finn nemzet sajátossága ragyogásának és dicsőségének tudatában, glóriával ékesítve felkeltené a kortársak és az utókor csodálatát." ${ }^{\prime 3}$

Azt, hogy Lönnrot ismerte-e vagy sem Gottlund bírálatát, nem tudni. ${ }^{34}$ Mindenesetre nem utalt sem levelezésében, sem a Kalevala megjelenése után, az összeszerkesztésről írott cikkeiben a gottlundi gondolatra.

\subsubsection{Runógyüjtemény Väinämöinenről. Az Ős-Kalevala}

Lönnrot népköltészet iránti érdeklődését valószínűleg tanárának, Reinhold von Beckernek az 1820-as években megjelent írásai keltették fel. Záró vizsgadolgozatát is Becker irányításával Väinämöinenről írta De Väinämöine, priscorum Fennorum numine címmel. Ebben a munkájában Väinämöinen, amint a cím is utal rá, még istenségként jelent meg. Dolgozata jelentősége abban állt, hogy már ebből kitűnt Lönnrot rendkívüli tájékozottsága a korábbi népköltészeti gyűjtésekben, valamint a gyűjtők és ideológusok Agricola, Porthan, Ganander, Rühs - munkáiban. A Lönnrot által ábrázolt Väinämöinen-képben egyaránt jelen volt a különféle mitológiák ábrázolta félistenek és hősök jellemvonása, valamint az 1700-as évek finn elgondolásai. Vagyis Väinämöinen egyszerre Kaleva legtehetségesebb félistene és istene, a világ teremtője, hős. De mindenekelőtt énekes, kultúrhérosz, a harmónia megteremtője. ${ }^{35}$

1827-ben, amikor a turkui tüzvész miatt az egyetemen szünetelt a tanítás, Lönnrot elindult Hämébe, első gyüjtőútjára. A gyüjtött lírai dalokból és siratókból már 1829-ben megjelentett egy kötetre valót Kantele taikka Suomen Kansan Vanhoja sekä Nykyisiä runoja ja lauluja (Kantele, avagy a finn nép régi és új runói és dalai) címmel. Väinö Kaukonen szerint a gyüjtésnek és a gyüjtött anyag kiadatásának kettős oka volt: „,meg akarta menteni a runókat a pusztulástól, mivel egyaránt a múlt megismerésének fontos forrásai, másrészt pedig költői értékük miatt." ${ }^{36} \mathrm{~A}$ lejegyzett anyag megjelentetésétől az eposzig vezető út, valamint az eposz gondolatának a meg-

\footnotetext{
${ }^{33}$ Idézi KAUKONEN 1983: 20.

${ }^{34}$ Karkama valószínűnek tartja, hogy Lönnrot ismerte Gottlund kritikáját. Lásd KARKAMA 2001: 247, 345.

${ }^{35}$ Vö. uo. 248.

${ }^{36}$ KAUKONEN 1983: 41.
} 
fogalmazódása és koncepcionális fejlődése főként Lönnrot levelezéséből követhetô nyomon. ${ }^{37}$

Az 1831-ben és 1832-ben tett - szám szerint - második és harmadik gyűjtőút tapasztalatairól levelekben számolt be Lönnrot. 1833-ban a FIT titkárának, K. N. Keckmannak írott levelében az olvasható, hogy olyan epikus énekeket sikerült feljegyeznie, melyek központi alakja főként Väinämöinen, mellette pedig Ilmarinen és Lemminkäinen az állandó szereplők. Ugyanez év augusztusi levelében már körvonalazódni látszott a lönnroti (össze)szerkesztési elképzelés. Csírájában már ez a levél tartalmazta a későbbi nagy epikai mü megszerkesztésének gondolatát: „Mi lenne, ha a Társaság [FIT] újból kinyomatna minden finn runót, amely erre érdemes, oly módon, hogy sorba szedné őket, aszerint, mi található különböző helyeken Väinämöinenről, Ilmarinenről, Lemminkäinenről, majd egybeolvasztaná vagy füzné őket, és a lectiones variantes [különböző változatokat] valahol lent helyezné el, vagy az utolsó lapokon." ${ }^{38}$

A munkát a Lemminkäinenről szóló epikus részek összeszerkesztésével kezdte. Azonban még mielőtt ez megjelent volna, Lönnrot újabb gyüjtőútra indult: a negyedikre. Ekkor találkozott azokkal az énekesekkel, akiket a mai napig számon tart a szakirodalom: Ontrei Malinennel és Vaassila Kieleväinennel. Tölük jegyezte le többek között a Szampó-ciklust, a Vipunenben-járást vagy a Kantele születését. Ezeknek az énekeknek a központi hőse Väinämöinen, ezért eredeti tervével ellentétben a Väinämöinenről szóló énekek összefüzésébe kezdett. Amikor azonban az Ilmarinenről és Lemminkäinenről szóló részre került a sor, ráébredt, hogy e két személy olyannyira beépült a már elkészült Väinämöinen-ciklusba, hogy nincs elég anyaga ahhoz, hogy minden hősről külön részt állíthasson össze. Tulajdonképpen ez a kényszerhelyzet szülte a Runokokous Väinämöisestä (Runógyüjtemény Väinämöinenről) ciklust. A címadásra - "gyűjtemény" - jellemző Lönnrot akkori felfogása: a lejegyzett anyag egy központi figura köré szerveződő részének (feltételezett) kronológiai sorrendbe állítása. Väinö Kaukonen szerint ez a ciklus tárgyánál és szerkezeténél fogva - az első énekek egyike a világ teremtéséről szól - már eposznak is nevezhető. Bár tele van tárgyi ellentmondásokkal, a szakirodalom egyetért abban, hogy fontos lépést jelentett a nagyobb epikai egység felé. Ezért is tartják Ős-Kalevalaként számon.

\footnotetext{
${ }^{37}$ A továbbiakban Lönnrot levélrészleteit Kaukonen 1983-as könyvéből idézem.

${ }^{38}$ KAUKONEN 1983: 48.
} 


\subsubsection{A Kalevala első kiadása. A Régi Kalevala}

A Kalevalával foglalkozó szakirodalom a runóénekesek közül hat jelentőset tart számon: a már említett Ontrei Malinent és Vaassila Kieleväinent, valamint Mateli Kuivalatart, Larin Parasket, Juhana Kainulainent és Arhippa Perttunent. Ők azok, akiktől a leghosszabb és legösszefüggőbb epikus és lírai énekeket gyüjtötték. A két utóbbival Lönnrot ötödik gyűjtőútján találkozott 1834 áprilisában. A Perttunentől lejegyzett énekváltozatok arra ösztönözték Lönnrotot, hogy az előző évben kiadásra elküldött Runógyüjtemény Väinämöinenről ciklust új változatokkal egészítse ki és leállítsa a már elküldött anyag megjelentetését. A kiegészített változat 1835 . február 28-ra készült el. Címe: Kalevala taikka Vanhoja Karjalan Runoja Suomen kansan muinaisista ajoista (Kalevala, avagy a finn nép hajdani történetéről szóló régi karjalai runók). Amint a címből is kiderül, Lönnrot nem csupán kiegészítette, hanem át is dolgozta az 1833-ban megjelenésre kész anyagot. A címben szereplő Kalevala Kaleva földjét jelenti. A szóválasztás már egy új koncepció születéséről tanúskodik. A Runógyüjtemény Väinämöinenról címében is utalt arra, hogy olyan gyưjteményről van szó, mely egy hős köré építi a történéséket. Ezzel szemben az új változat Kalevalája görög mintára került a címbe. Erről maga Lönnrot írt az 1835-ös kiadás elő́szavában: „A görögök is Iliadának hívták a homéroszi dalok egy részét, bár nem mindig Ilion területén játszódik [a cselekmény]." ${ }^{39}$ Ugyancsak görög mintára a cselekményt Kalevala és Pohjola között zajló harc köré szervezte. A cselekményszervezés módja, a görög mintán kívül Hegel eposzfelfogására - a harc jelenléte az eposzban elengedhetetlen -, valamint Gabriel Rein Väinämöinenről mint történelmi hősről írt cikkére vezethető vissza. Rein szerint Väinämöinen feltehetőleg a finnek egyik vezére volt. A finn honfoglaláskor a finneknek a lappokkal kellett a területekért harcolniuk. Väinämöinen pedig a finn törzs(ek) vezéreinek egyike lehetett. A lappok a finnek elől északra menekültek. E két terület: Finnország déli és északi része lehet tehát a runókban előforduló Kalevala és Pohjola. Rein romantikus történelemszemléletét Lönnrot csak részben vette át. Szerinte a népköltészeti alkotásokból kiolvasható történelem nem feleltethető meg a történelmi valóságnak. A kettő nem áll ellentétben egymással, hanem inkább kiegészítik egymást. Lönnrot például a finn-lapp harcok történelmi valóságosságát nem vetette el, de azzal sem értett egyet, hogy a műben előforduló lapp szó műbeli jelentése megfeleltethető lehetne a szavak 19. századi jelentésének vagy a helységnevek a 19. században is létező helységet jelölnének.

\footnotetext{
${ }^{39}$ Idézi uo. 79.
} 
Az első kiadás recepciójának e kettős történelemfelfogás a kiindulópontja. A mủ népi, illetve múeposzként való meghatározása leginkább a második kiadás recepciójára jellemző. Az első kiadást K. A. Gottlundon kívül mindenki népeposzként kezelte. Gottlund éppen azt kifogásolta, hogy a mű Lönnrot egyéni alkotómunkája, mely a népköltészetből építkezik ugyan, de a gyưjtött anyagon Lönnrot által végzett módosítások „elsilányítják" az eposzt. Erik Alexander Ingman, Jakob Grimm, Henrik Piponius, Matias Aleksanteri Castrén vagy Robert Tengström a Kalevalát hiteles, eredeti őseposznak tartotta. A kritikákban megfigyelhető különbség a bírálók történelemfelfogásából és a 19. századi romantikának az epikus népköltészeti alkotások interpretálásának a különböző módjából adódik: a mitológiai vagy a történelmi szempont érvényesítéséből. E. A. Ingman, J. Grimm a mitológiai, H. Piponius, M. A. Castrén és R. Tengström a történelmi szempontot képviselte.

A német Jakob Grimm érdeklődését a finn folklór iránt a Schröter által németre fordított finn népköltési gyüjtemény keltette fel. A Kalevalával M. A. Castrén 1841-es svéd fordítása révén ismerkedett meg. Germán Mitológiájában, mely 1844-ben jelent meg, utalt is rá. 1845-ben pedig a berlini Tudományos Akadémián tartott előadásában a finn eposzt az ősi görög, német és skandináv mitológiákkal állította párhuzamba. Grimm felfogásában a népköltészet epikus darabjai utalásokat tartalmaznak egy nép írásbeliség elôttti történelmére vonatkozóan. Ám míg a történelem valós történésekre épül, az írásbeliség előtti ősköltészet mitológiai történéseken alapul, és szájhagyomány útján terjed. Grimm mitológiai perspektívájából nézve Väinämöinen, Ilmarinen és Lemminkäinen istenek voltak: „Azon az eleven valóságon át, melyet az eposz nyújt hősei számára, áttetszik a mitikus alap. Emberi gyengeségeiket sehol sem tagadják le, panaszkodnak a sorsukra, sírnak, ki vannak téve a szerencsétlenségeknek, melyeket nem tudnak mindjárt legyőzni; de gyakran és annál erősebben tör elő belőlük máshol az isteni erő és cselekvés. Väinämöinen, Ilmarinen és Lemminkäinen kétségkívül valóságos istenek és figyelemre méltó triászt alkotnak, amely más mitológiákra emlékeztet." ${ }^{40}$

Fabian Collan már 1831-ben úgy írt Väinämöinenről és Ilmarinenről, mint a hajdani finnek legfelsőbb isteneiről, elvetve a történelmi perspektíva létjogosultságát. Egy évvel később álláspontja annyiban változott, hogy elismerte, kellő kritikai hozzáállással a történelmi szempont is érvényesíthetô lehet. Ugyanakkor úgy vélte, hogy a finn-lapp harcok nem lehettek történelmileg eléggé fontosak, nem lehettek egy hőskor harcai, következésképpen nem képezhetik eposz tárgyát.

\footnotetext{
${ }^{40}$ Idézi uo. 139.
} 
E. A. Ingman ugyancsak a mitológiai perspektívát érvényesítette 1836os Några ord om Kalevala (Néhány szó a Kalevaláról) című előadásában. Véleménye szerint az eposz olyan mitikus mü, melyben Kalevala és Pohjola harca a világosság és a sötétség harcát jelképezi.

H. Piponius 1839-es kritikájában a mitikus perspektívával szemben a történelmi mellett foglalt állást. Cikkében magát az eposzt bírálta ellentmondásossága miatt: „,egy távoli kor sajátos kultúrájának, vallásos felfogásának és társadalmi intézményének hézagos visszhangjainak" ${ }^{41}$ tartotta.

Az eposz svédre fordítója, $M$. A. Castrén ugyancsak történelmi szempontból közelítette meg a múvet. Az 1841-es svéd fordítás elé írt bevezetőjében és a Kalevaláról tartott előadásaiban a runók sorrendjét, az egységességet, valamint a mű cselekményében rejlő ellentmondásosságokat kifogásolta. Kritikai megjegyzései tulajdonképpen az eposz szerkezeti felépítésére vonatkoznak. Magát a múvet hiteles népi alkotásnak tartotta, melynek sorai „évszázadok keresztül szólnak éjmély szavakat az ősök hitéről, bölcsességéről és erejéről” és „,az ősi hőskorról mesélő történelmi dokumentum." ${ }^{42}$ A szerkezeti hiányosságokra utalva Castrén főként azt várta el a Kalevalától, hogy az események olyan sorrendben kövessék egymást, ahogyan az ősidőkben valójában tették. A feltételezett őseposz rekonstruálhatóságának hitében gyakorlatilag figyelmen kívül hagyta, hogy bíráló megjegyzései esetleg éppen Lönnrot betoldásait vagy módosításait érintik. Ami a műfaji kérdéseket illeti, két különálló versműnek tekintette a Kalevalát: az egyik a szampó köré, a második pedig a leánykérés köré szerveződik. A cselekmény alapján rögtön adódott is számára a homéroszi analógia: az első az Iliásszal, a második az Odüsszeával rokon.

Piponius és Castrén kritikái után R. Tengström 1845-ben két - Kalevaláról szóló - tanulmányt is megjelentetett, melyek ugyancsak történelmi szempontból vizsgálják az eposzt. Azonban ez a történelemszemlélet jelentősen különbözött a fentebb már idézett szerzők történelemszemléletétől. Tengström hitt ugyan abban, hogy a Kalevalában megjelenő történések kiindulópontja a történelembe ágyazódik, ugyanakkor azt vallotta, hogy művészi jellegüknél fogva meglehetősen eltávolodtak a konkrét történelmi eseményektől és személyektől. Tanulmányában hangsúlyozta, hogy a Kalevalát műalkotásként, egy nép civilizációs fejlődésének és ízlésének termékeként vizsgálja: többrétegü müként, melyben a különböző rétegek a különböző korszakokban megnyilvánuló világhoz való viszonyulást tükrözik. Tengström hegeliánus eposzfelfogása ellentétben áll a romantika schlegeli eposzfelfogásával. Ő ugyanis azt feltételezte, hogy minden nép-

\footnotetext{
${ }^{41}$ Idézi uo. 114. [kiemelés tőlem, V. P. I.]

${ }^{42}$ [eredeti szöveg:] „puhuvat meille läpi vuosisatojen yön syvällisiä sanoja isien uskosta, heidän viisaudestaan ja voimastaan" "muinaisesta sankarikaudesta kertova historiallinen dokumentti" Idézi KARKAMA 2001: 273. [fordítás tőlem, V. P. I.]
} 
nek, így a finnek is, volt hőskora. Az akkor elkezdődött fejlődési folyamat azonban a kereszténység térhódításával megszakadt. Véleménye szerint a Kalevala utolsó runójában olvasható Väinämöinen búcsúja éppen erre a hőskorszak-kereszténység felvétele fordulópontra utal. Väinämöinen az eposz szerint csak akkor tér vissza Kalevalába, amikor szükség lesz rá, amikor a nép ismét szükségét érzi majd a szampó elkészítésének. Ez a pillanat Tengström értelmezésében egy új államforma létrejöttét jelképezi: a nemzeti államét.

Részben Tengströmmel szemben foglalt állást a kor ideológusa, J. V. Snellman. ${ }^{43}$ Snellman tagadta a finn hőskor létét, majd bizonyos fenntartásokkal, de elfogadta meglétének lehetőségét. Szerinte, ha a finneknek volt is hőskoruk, az nem lehetett hasonló az Iliász vagy a Nibelung-ének hőskorához, mint ahogyan Väinämöinen vagy a többi kalevalai hős is különbözik a klasszikus eposzok hőseitől. Grimm előadása nyomán Tengström éppen a Kalevalának a klasszikus eposzokhoz való hasonlóságára mutat rá. A mü csodás részeit is a történelmi szempont érvényesítésével értelmezi. A szampó-ciklus szerinte a kultúra és civilizáció korszakát jelképezi a finn történelemben. Az, hogy Kaleva népe elveszíti a szampót, és egy újat már nem képes létrehozni, a történelemben bekövetkezett stagnálásra utal, amely az 1809-ig tartó svéd uralom időszakának feleltethető meg.

Snellman a Kalevalában az általa olyannyira áhított finn nyelvü müvet látta megszületni, mely reményei szerint letéteményese lehet a finn nyelvű nemzeti irodalomnak. Ezért számára nem a mü értelmezésében érvényesített történelmi vagy mitológiai szempontok relevanciája volt a meghatározó. Az eposz azoknak az irodalommal kapcsolatos - ekkor még csak formálódó - nézeteinek az igazolása volt, melyeket később, az 1840es években fogalmazott meg. Felfogásában olyan finn nyelvű mü lehet a finn nemzeti irodalom része, mely a finn nemzeti tudatot tükrözi és fenntartja azt a nemzeti szellemet, melyből született. ${ }^{44}$ A Kalevala megjelenése után a nemzet és nemzeti irodalom összefüggése olyan dialektikus kijelentésben fogalmazódott meg, miszerint „a finn nemzet, mert van nemzeti irodalma". ${ }^{45}$

Az eposz első kiadása utáni közvetlen reagálásokban tehát legerősebben a történelmi perspektíva érvényesült. Ez a tendencia összefüggésben állt a kor ideológiájával, a történelem és nép közötti összefüggésekről alkotott elképzelésekkel. ${ }^{46}$ Lönnrot Kalevalája az 1809 utáni új politikai egység, Finnország (ős)történetét rajzolta meg, mely a német romantika filozófi-

\footnotetext{
${ }^{43}$ A Tengström - Snellman vita KARKAMA 1989 alapján.

${ }^{44}$ Lásd a 2.2.2. alfejezetet.

${ }^{45}$ [eredeti szöveg:] „Suomi on kansakunta, koska sillä on kansalliskirjallisuutta." [fordítás tőlem, V. P. I.] Idézi LAITINEN 1981a: 186.

${ }^{46}$ Lásd a 2.2.2. alfejezetet.
} 
ájának nyomán a finn nép egységét kívánta hangsúlyozni. Így látta ezt a FIT is, melynek akkori elnöke J. G. Linsén egy 1836-ban tartott gyülésen a következőképpen nyilatkozott: „Az ősi finn dalok kincsesháza, mely nem olyan régen e Társaság kiadásában jelent meg, annyiban rendkívül jelentős, hogy ezen keresztül hazai irodalmunk nem csupán mérhetetlenül gazdagabb lett, hanem európai mércével is mérhetôvé vált. Dicsekvés nélkül mondhatjuk tehát, hogy irodalmunknak ezzel alkalma lett kilépni bölcsőjéből. Finnország ezen epikus dalok birtokában erősödő értéktudattal tanulhatja meg helyesen megérteni majdani szellemi fejlődését. Finnország ezt mondhatja magának: nekem is van történelmem!" ${ }^{47}$

\subsubsection{A Kalevala második kiadása. Az Új Kalevala}

Lönnrot már 1835-ben, a Kalevala első kiadásának megjelenése után, hiányosnak érezte az eposzt. Feltételezte ugyanis, hogy vannak még olyan területek, ahol új anyagot lehetne gyüjteni. Ezért még ugyanabban az évben és az azt követố négy évben négyszer indult gyưjtóútra. Útjaira a FIT segítőtársakat is rendelt. Az 1840-es években a gyűjtést már többnyire mások végezték, és a gyűjtött anyagot elküldték Lönnrotnak. Rá az összeszerkesztés feladata hárult. A szervezett gyüjtés a Kalevala első kiadásának fogadtatása nyomán indult el. A bírálatok és a körülötte kialakult vitáknak tulajdoníthatóan az eposz a figyelem középpontjába került. Ez a tény pedig „olyan eleven, céltudatos és eredményes buzgalmat ébresztett Finnországban a régi, hagyományként megőrződött népi runók gyűjtése iránt, amilyenre korábban nem volt példa az országban és máshol sem. Az új lelkesedést az a korábbinál szilárdabb meggyőződés okozta, hogy a népköltészet nemcsak az egyik legfontosabb forrást és bizonyítékot szolgáltatja a néprajznak és történelemnek hajdani idők életének és körülményeinek a kutatásában, hanem megvilágíthatja a finn nép őstörténetét is." ${ }^{48}$

Az eposz interpretálásában Lönnrot is a történelmi szempontot vélte leginkább relevánsnak. A második kiadás előszavának első soraiban megjegyzi, hogy a mű célja a finn nép őskorának a korábbiaknál teljesebb leírá-

\footnotetext{
${ }^{47}$ [eredeti szöveg:] „Suomalaisten muinaisrunojen aarre, joka on hiljan ilmestynyt painosta tämän Seuran kustannuksella, on sikäli varsin merkityksellinen, että kotimainen kirjallisuutemme ei ole sen kautta ainoastaan äärettömästi rikastunut, vaan on siinä päässyt eurooppalaiselle tasolle. Voidaan siis ylvästelemättä sanoa, että kirjallisuutemme on vasta nyt päässyt kehdostaan. Omistaessaan nämä eeppiset runot Suomi voi voimistuneella omanarvotunnolla oppia oikealla tavalla ymmärtämään vastaista henkistä kehitystään. Suomi voi sanoa itselleen: Myös minulla on historia! (1836. 03. 16. Esimies J. G. Linsénin puhe)" [fordítás tőlem, V. P. I.] HIRVONEN - MAKKONEN - NYBONDAS 1981: 31.

${ }^{48}$ KAUKONEN 1983: 174.
} 
sa: „Ez az őseink létéről, életéről és életmódjáról szóló könyv most sokkal teljesebb formában jelenik meg, mint eddig." ${ }^{49}$

A két kiadás között eltelt tizennégy évben többen is hozzájárultak gyưjtésükkel ahhoz, hogy az új kiadás teljesebb legyen. Lönnrot név szerint felsorolja a gyüjtőket: J. F. Cajan, M. A. Castrén, D. E. D. Europaeus, A. E. Ahlquist, Fr. Polén, Z. Sirelius és H. A. Reinholm. Kiemeli közülük D. E. D. Europaeus munkáját. ${ }^{50}$ Ugyanakkor az énekesek közül senkit sem említ meg, a legfontosabbakat sem..$^{51}$ Elöszavában csupán tájegységekre, falvakra utal, ahol ezekkel az énekesekkel találkozott. Az anonimitást nemcsak az énekesek nevének elhallgatásával hangsúlyozza Lönnrot, hanem az előszóban használt igei formákkal is. Egyes szám első személyű igealakot egyetlen egyszer sem használ. Amikor saját alkotói munkájáról ír, akkor is személytelen igemódban (passzívumban és infinitívuszban) levő igével utal az összeszerkesztésre: „ne tulevat olemaan vanhimpana omituisena jälkimuistona Suomen kansalle ja kielelle, kunnes niitä maailmassa löytyy, on niitä kaikella mahdollisella huolella ja ahkeruudella pyydetty sovitella ja liittää toinen toisiinsa niin hyvästi, kuin van on osattu, ja koota niihin kaikki, mitä runot senaikuisesta elämästä, tavoista ja vaiheista ovat tiedoksi säilyttäneet." 52 Ugyancsak az anonimitást szolgálja, hogy Lönnrot neve egyik kiadás fedőlapján sem szerepel. Gyakorlatilag csak az aláirt és dátumozott előszavak utalnak arra, hogy Lönnrotnak valamilyen szerepe lehetett az eposz létrejöttében. Ezt a magatartást Pertti Anttonen a „nép mögé bújás", a népi énekesekkel való azonosulni akarás szerepjátékának tartja. ${ }^{53}$

Az új kiadás összeszerkesztése idején íródott lönnroti levelek azonban egy tudatos szerkesztő, alkotó képét idézik. Lönnrot tisztában volt azzal, hogy az eposz népköltészeti alapokra épül ugyan, de saját íróasztalán készül: egyéni szerkesztő- és alkotómunkájának az eredménye, mely

\footnotetext{
${ }^{49}$ [eredeti szöveg:] „Tämä kirja esivanhempimme muinaisesta olosta, elämästä ja toimista ilmestyy nyt paljo täydellisempänä, kun minkä entisessä korjuussansa oli." [fordítás tőlem, V. P. I.] LÖNNROT 1995 [1849]: I.

${ }^{50}$ D. E. D. Europaeus gyűjtőútjairól V. Salminen írt részletesen. Salminen úgy véli, hogy D. E. D. Europaeus nagyobb területeket járt be, mint Lönnrot és több epikus éneket sikerült összegyưjtenie, mint Lönnrotnak. Vö. SALMINEN 1906.

${ }^{51} \mathrm{Az}$ ismert énekesek nevét Lönnrot és a többiek mindennapos naplószerű lejegyzéseiből ismerjük.

${ }^{52}$ [magyar fordítása:] „Nem szabad elfelejteni, hogy ezek a finn nép és nyelv legrégibb sajátos emlékei, míg csak élnek; a lehető legnagyobb gonddal és szorgalommal azon voltunk, hogy tehetségünk szerint a lehető legjobban elrendezzük, egymáshoz kapcsoljuk őket, és mindent beléjük sürítsünk, amit a runók az akkori életről, szokásokról és körülményekről megőriztek." [Bereczki Gábor fordítása]. A magyar fordító többes szám első személyben fordítja az igéket, mely - véleményem szerint - visszaadja a lönnroti anonimitásra való törekvést. [kiemelés tőlem $V$. P. I.]
}

${ }^{53}$ ANTTONEN 2002: 44. 
egy másfajta koncepció függvényében lehetne teljesen más is. Erről ír F. Collannak 1848. április 25-én: „,az összegyüjtött runókból most bőven össze lehetne állítani hét Kalevalát is, s ez mind különböző lenne." ${ }^{54}$

Lönnrot tehát egyszerre volt szerkesztője és - az énekeket írásban rögzítőként - alkotója a Kalevalának. Tudatos alkotóként igyekezett figyelembe venni az első kiadást ért bírálatokat. Különösen a Kalevalát svédre fordító M. A. Castrénnak a cselekmény ellentmondásosságára vonatkozó megjegyzéseit. Így nyerte el például a Teremtés-történet végleges, második kiadásbeli alakját. Az első kiadásban ugyanis Väinämöinen világra jövetele érdekében könyörög az égitestekhez, hogy segítsenek neki megszületésében. Majd születése után teremti meg a Napot és a Holdat. Az új változatban az égitestek a búvárkacsa tojásaiból jönnek létre, majd ezek után segédkeznek Väinämöinen születésében. Ugyancsak a cselekmény logikus vonalvezetését szem előtt tartva Lönnrot bizonyos személyeket eggyé olvaszt: Väinämöinen anyját, Ilmatárt és Vízasszonyt; Lemminkäinent, Ahtit és Kaukomielit; Kullervo gazdasszonyát és Ilmarinen pohjolai feleségét. A legtöbb változtatás a keresztény elemek kiiktatásában figyelhető meg. Például a szampó visszaszerzésének történetében a csónakút szereplőinek a megváltoztatása. Az énekesek variációiban Väinämöinen Szűz Máriát vagy valamelyik apostolt kéri fel, hogy evezzen. A Kalevalában Ilmarinent teszi meg evezősnek. Ennek oka Lönnrotnak az eposz cselekményének idejéről vallott felfogása. Szerinte a cselekmény valamikor az őskereszténység előtt játszódhatott, ezért semmiképpen sem illenek a keresztény elemek a pogány kori eposzba. A szájhagyomány útján terjedő népköltészetre jellemző módon a szöveg módosulhat, vagyis a keresztény elemek később kerül(het)tek be az énekekbe. Az utolsó runó keresztény elemei azért maradhattak az eposzban, mert az éppen a finn őstörténetben bekövetkezett korszakváltásra utalnak: a kereszténység felvételére.

A Litteraturblad 1849-es számában Lönnrot önmagát a runóénekesek közé sorolja. Alkotói munkáját az énekesek előadási technikájához hasonlónak véli. Az énekesek, mivel csak emlékezőtehetségükre hagyatkozhatnak a runók előadásakor, az énekek szövegén folyton változtatnak. Tulajdonképpen ezt tette Lönnrot is, amikor a legjobb sorokat választotta ki az énekvariációkból, vagy amikor egy-egy, a „Kalevala szellemében” önmaga költötte sort betoldott. Erre runóénekesi minőségében felhatalmazva érezte magát. Ezen kívül pedig szem előtt tartotta R. Tengström eposzfelfogását is, miszerint: „,a nagy epikus versművek egyidejüleg egy személy alkotása és több összhatás eredménye. Egy egységes, művészi versmű egy

\footnotetext{
${ }^{54}$ Idézi KAUKONEN 1983: 203.
} 
költőt kíván, másrészről viszont a mondák a néplélek termékei gyanánt mindenki ajkán éltek, s nemzedékről nemzedékre öröklődtek." ${ }^{55}$

Lönnrot a Kalevala alkotójaként nem csupán (népi) költői, hanem nyelvészeti munkát is végzett: köznyelvesítette az énekek nyelvjárási vonásait mind lexikai, mind formai szempontból.

A Kalevalának mint tisztán népköltészeti alkotásknak a vizsgálata Lönnrot népköltészetről, eposzról és nyelvről vallott felfogásának a figyelmen kívül hagyását jelenti. A műfaji kérdést: népi vagy műeposz-e a Kalevala, a kutatók, irodalomtörténészek a 19. századtól kezdve napjainkig ellentmondásosan kezelték. A finn irodalom történetéről szóló legfontosabb munkák hol a népi, hol a múeposz jelleget hangsúlyozzák. Julius Krohn 1897-ben arra hívta fel figyelmet, hogy a Kalevala nem válhat a népköltészeti kutatások forrásává, ${ }^{56}$ Unto Kupiainen ugyancsak müeposzként kezeli. ${ }^{57}$ Velük ellentétben Kai Laitinen - bár hangsúlyozza, hogy a Kalevala Lönnrot szerkesztésének eredménye - a népköltészet fejezetben ír az eposzról. ${ }^{58}$

A kutatók sorában Rafael Koskimies egyfelől arra figyelmeztet, hogy a mú esztétikai vizsgálatakor tekintetbe kell venni az eposz népköltészeti alapjait, valamint Lönnrot teremtő (sic! 'luoja') munkáját is. Másfelől úgy véli, hogy a Kalevala eszmei háttere független Lönnrottól, csupán a népköltészeti alap a meghatározó annak vizsgálatában. Mert a nép semmit sem tudhatott Arisztotelészről, Goethéről, Schillerről vagy Hegelről. ${ }^{59}$

Laitinen irodalomtörténetének teljesebb finn változatában a népköltészetről szóló fejezet lektoraként, ahol a Kalevaláról is szó van, Väinö Kaukonen működött közre. ${ }^{60}$ Kaukonen, a mű egyik legalaposabb vizsgálójaként, ${ }^{61}$ mindig is a Kalevala múeposzjellegét hangsúlyozta, de ő sem foglal állást kizárólagosan egyik vagy a másik mellett: „Bár a Kalevala, mint Lönnrot versmüve, az igazi népköltészet-kutatáson, a tárgyi és

\footnotetext{
${ }^{55}$ Idézi uo. 222.

${ }^{56}$ Vö. KROHN 1897. Murteitten taistelun aika címü fejezetben.

${ }^{57}$ Vö. KUPIAINEN 1958.

${ }^{58}$ Vö. LAITINEN 1981b.

${ }^{59}$ Vö. KOSKIMIES 1978: 7-19.

${ }^{60}$ A népköltészet fejezet Satu Apo munkája. Apo Kaukonen felfogását követve műeposznak tartja a Kalevalát, és anakronisztikusnak minősíti például Matti Kuusi Kalevalaista kertomarunoutta (Kalevalai epikus költészet) népköltészeti gyüjteményének címválasztását, mivel a Kalevala szó Lönnrot zseniális „találmánya” volt, és valójában semmi köze nincs a népköltészethez. A Kuusi - Kaukonen vitáról bővebben lásd LAAKSONEN - PIELLA 2002 utolsó tanulmányait.

${ }^{61}$ Kaukonen évtizedeken keresztül vizsgálta a Régi és az Új Kalevala összeszerkesztésének körülményeit, a lönnroti koncepció fejlődését. A ma kézikönyvként használt $A$ Kalevala születése című könyve kutatási eredményeinek rövidített változata.
} 
szellemi néprajz és a történeti nyelvtudomány vizsgálati területén kívül esik, ezeknek a tudományoknak nagy szerepe van az eposz népéleti hátterének a megvilágításában. Mivel a versmü a régi népköltészeti motívumok és metaforák kimeríthetetlenül gazdag kincsestára, az említett tudományoknak mindig lehetőségük van arra, hogy megelevenítsék az archaikus eposz költöi valóságát". ${ }^{62}$

A magyar Kalevala-kutatók közül Korompay Bertalan is Kaukonenhez hasonlóan vélekedik. Ugyanakkor igyekszik arra is választ találni, hogyan és miért kerülhetett a finn eposz a világirodalmi központba. A finn eposz létrejöttének feltételeként azt a "romantikus axiómát” nevezi meg, mely szerint „minden olyan népnek, mely bizonyos szellemi képességeknek már ősidőkben birtokába jutott, volt naiv eposza, illetőleg annak valamely kezdeti formája. (...) amikor az axiómával kapcsolatba került a nemzeti gondolat s amikor szinte megrögzött hitté vált a kisebb, ismeretlenebb népek körében, hogy ha nemzeti eposzt tudnak felmutatni, akkor az irodalom és a nép, amely azt létrehozta, egyszerre közfigyelem tárgya lesz $\mathrm{s}$ előkelő helyet fog elfoglalni a világirodalomban." ${ }^{63}$

A legújabb irodalomtörténet kompromisszumos megoldáshoz folyamodik: Kansaneepos - taide-eepos (Népi eposz - múeposz) cím alatt foglalkozik a Kalevalával. ${ }^{64}$ Ugyancsak ez az irodalomtörténet lehetségesnek tart egy Kalevala előtti és utáni irodalmi korszakolást is. ${ }^{65}$

Összegzésként elmondhatjuk, hogy a Kalevalának mint irodalmi münek a társadalomtörténeti és múvészi értelemben vett hatása elválaszthatatlan egymástól. A finn nemzeti identitás kialakulása és megerősödése a 19. században a svéd - és ezen keresztül a német - kultúrától, nemzettől való elhatárolódás révén ment végbe. A Kalevala éppen azért válhatott a finn identitás hordozójává, mert - a történelmi értelmezés szerint - a törzsi viszonyok között élő ősfinnséget ábrázolta; egy olyan történelmet, mely a svéd történelemtől független. A Kalevala mint az ősfinnség történelmének a megjelentetése az önálló nemzetként való (ön)meghatározás példája. Az eposz majd kétszáz éves finn fogadtatástörténetében a különféle olvasatok legtöbbször a mű nemzetiidentitás-teremtő szerepére kérdeztek rá. Nem csupán az irodalomban, hanem a társmüvészetekben is: a színház, a zene, a festészet területén. A művészek különösen azokban az időszakokban fordultak a Kalevalához, amikor a finnség, a finn államiság szempontjából erre szükség mutatkozott: a 19. és 20. század fordulóján a késői romantika és a realizmus korszakában többek között az író Aleksis Kivi, Juhani Aho

\footnotetext{
${ }^{62}$ KAUKONEN 1983: 232. [kiemelés tőlem V. P. I.]

${ }^{63}$ KOROMPAY 1989 [1935]: 19-21

${ }^{64}$ Vö. VARPIO - HUHTALA 1999: 213.

${ }^{65}$ Vö. uo.
} 
és a költő Eino Leino az irodalomban, Akseli Gallén-Kallella a festészetben vagy Jean Sibelius a zenében, Aulis Sallinen, Kalle Holmberg, Paavo Haavikko, Mauri Kunnas és Kai Nieminen a 20. század végén és napjainkban.

Emellett pedig összekötő kapocsként működött a finn-magyar nyelvrokonságot (vagy éppen néprokonságot) ápolni óhajtók között, sokszor akár állami szinten is.

\subsection{A nemzet fogalmának változása a magyaroknál és a nemzeti nagyelbeszélés}

A finnel összehasonlítva a magyar többrendszerben a nyelvvel és annak a kultúrában játszott szerepével kapcsolatos elméleti fejtegetések és ezek gyakorlatba ültetése majd' fél évszázaddal korábbra tehető. Kazinczyék törekvéseiben a turkui majd helsinki romantikusokéval rokon elemeket és vonásokat fedezhetünk fel. Az eltérések inkább időbeliek, mintsem ideológiaiak.

\subsubsection{Nemzetfogalmak és irodalomfelfogások}

A nemzeti újjászületés eszméje, a két irodalmi rendszer közötti fáziskülönbség miatt, a magyar irodalomban a finnél korábban, már az 1780-90-es években jellemző volt, azonban csak az 1820-30-as években teljesedett ki.

A nemzeti tudat kialakításában legfontosabb szerepe a nemzeti kultúrának volt. Ennek pedig egyik legalapvetőbb pillére a nyelv. A 18. század végén, a nyelvi alapokon nyugvó nemzeteszme mellett a - Finnországban különben ismeretlen - rendi nemzeteszme is általános volt. Ez utóbbi „,történeti jogi természetü, a Mi-tudat határvonalait a joghoz és a hatalomhoz való viszonya rajzolja ki." ${ }^{\prime 6} \mathrm{~S}$. Varga Pál megállapítására hagyatkozom a nemzetfogalmak leírásában, mivel ezeken keresztül ragadható meg legjobban a célkultúra viszonyulása a Kalevala-fordításokhoz, különösen ami a két első teljes magyar átültetést illeti. S. Varga három nemzetfogalomnak a 18. századi egymás mellett éléséről ír, melyek az államközösség, az eredetközösség és a hagyományközösség elvén alapultak. ${ }^{67} \mathrm{E}$ két utóbbi

\footnotetext{
${ }^{66}$ DEBRECZENI 2005b: 276.

${ }^{67}$ „Az államközösségi nemzetfogalom (...) a nemzetben egyazon uralkodó alattvalóinak közösségét látta. (...) A nemzet eredetközösségi felfogásában a történeti - genealógiai - narratíva játszotta a főszerepet, amely Kézai Simon Gesta Hungarorumán alapult (13. sz. vége); a magyar nemzetet eszerint a hunok örököseiként a Kárpát-medencébe visszatérő honfoglaló magyarság leszármazottjai alkotják. Kézai a nemzetet a nemességre korlátozta, melynek tagjai fegyverrel védték a hazát. (...) Az a szemlélet, amely a nemzetet hagyományközösségnek tekinti,
} 
nemzetfogalomhoz sajátos irodalomfogalom is kapcsolódott. Az államközösségihez nem kapcsolható irodalomfogalom, mivel az eredetközösségi elven alapuló nemzeteszme a század végére fokozatosan kiszorította azt, leegyszerüsítve azt is mondhatjuk, hogy éppen a nyelvkérdés működött a két nemzeteszme ellentéteként. ${ }^{68}$

A nemzetfogalmakhoz kapcsolódó irodalomfelfogások - az eredetközösségi nemzetfogalomban érvényre jutó literatúrafogalom ${ }^{69}$ és a hagyományközösségiben a poézisen alapuló irodalomfogalom ${ }^{70}$ - más-más követelményeket támasztottak a nemzeti nagyelbeszéléssel szemben.

A nemzettel kapcsolatos elbeszélés és a róla való gondolkodás 19. századi beszédmódja a 20. században a két világháború között válik újra divatossá: még az 1940-es években is valósággal megkívánja az egyházi, szakrális metaforák használatát. ${ }^{71}$

A leginkább az eredetközösségi irodalomfelfogáshoz kapcsolható nyugati hálóhoz idomulás a különböző műfajok, versformák - a textuális és konceptuális rács - átvételében és alkalmazásában nyilvánul meg. A 19. század közepén szinte mindenki az eposzt tartotta az egyedüli lehetséges múfajnak, mely betöltheti a nemzeti nagyelbeszélés szerepét: egyszerre „múltfeltámasztó" és ,„jövőteremto"”.

abból indul ki, hogy az emberiség egy-egy sajátos kulturális mintázat alapján elkülönülő részekre tagolódik, s ezek a nemzetek. A nemzet fennmaradásának kulcsa e mintázatnak a mindenkori jelenhez alkalmazkodó és idegen hatásokat asszimiláló hagyományozása, az emberiség fennmaradásának kulcsa pedig kulturális sokféleségének megőrzése." S. VARGA 2005a: 241-242. [kiemelés az eredetiben]

${ }^{68}$ Vö. S. VARGA 2005b: 228-231.

${ }^{69}$ „E felfogás szerint az esztétikumot az egyéni alkotóerő hozza létre. A klasszicizmus idején ezt az alkotóerőt az erudíció (kiműveltség) jelentette (...), később, a romantika korában a teremtő képzelet, ez biztosítja a mű eredetiségét. (...) Az irodalom e felfogásban tehát a kései írásos magas kultúrák terméke, és ezért, értelemszerủen, csak a társadalom magas műveltségű rétegeinek hozzáférhető." S. VARGA 2005a: 242. [kiemelés az eredetiben]

${ }^{70}$ "Míg a literatúrában a nyelv csupán eszköze az általánosan érvényes szépség kifejezésének (...), itt az irodalom alapja a nyelv, pontosabban, az egyes nyelvek kezdeti állapota. (...) Mivel minden nyelvben más és más a metaforikus gondolkodás jellege, a költő szépség az egyes nyelvekhez van kötve - ebben áll a költői művek eredetisége -, maga a költészet pedig, lévén a nyelv terméke, nem egyes egyének, hanem - mint a nyelv maga - lényegét tekintve a közösség alkotása, és így elvileg a közösség valamennyi tagja számára hozzáférhető: közköltészet. Ugyanezért a költészet eredetileg egy egész közösség egységes és teljes tudáskészletét hordozza (esztétikai funkciója tehát nem különül el kognitív funkciójától)." Uo. 242-243. [kiemelés az eredetiben]

${ }^{71}$ A nemzeti nagyelbeszélést romantikus törekvésnek tekintik, „,amely a dicsőnek látott mult alapján vázolja föl a jobban remélt jövő freskóit a nemzeti lélek templomának fehér falaira. Vörösmarty és Lönnrot tevékenységének egyik ihletrugója: régmult harci események költői formába öntésével az ősi dicsőség emlékeinek ápolása; a másik: nemzeti mitológia teremtésével a sajátosan nemzeti kultúra, a korszerü szellemi élet alapvetése, majd tömörvonalú katedrálissá való megépítése." VIRÁNYI 1940: 4. [kiemelés tőlem V. P. I.] 


\subsubsection{Eposz legyen-e vagy regény?}

A nemzeti nagyelbeszélést a magyar irodalomban - akárcsak a finnben - a nemzeti tudat kialakulásának, megerősítésének és fenntartásának eszközének tekintették.

Arany János Naiv eposzunk című tanulmányát egy kérdéssel kezdte: „Valahányszor idegen népköltészet egy-egy régi maradványa kerül kezembe, mindig elborultan kérdem magamtól. Volt-e nekünk valaha ősi eredeti eposzunk?" Majd válaszol is a kérdésre, miután a krónikákban fellelhető történeteket közelebbről is megvizsgálja: „Azt hiszem, hogy a felidézett nyomokból is kiviláglik már, hogy volt nálunk naiv eposz, s hogy az, mint általában a népköltemény, költői formában nyilatkozott. (...) Azonban dacára annak, hogy legrégibb történetírásunk, tudós naivságában megvetni, lenézni látszik a naiv költészetet. Az átszivárgott egyes helyek nemcsak ily eposzi nyomokat sejtetnek velünk, hanem egyszersmind a mese idomára is következtetést engednek húzni. A részletesség, mellyel Béla Névtelenje a honfoglalás személyeit s eseményeit, egész egyes adomákig ösmeri, kétségkívül az eposz részletessége; $s$ ha nem is egy magyar Nibelungen óriási izmait (...), de mindenesetre nagyrészt az élőhagyomány és népköltészet maradványait kell sajdítanunk e följegyzésekben”. ${ }^{72} \mathrm{Az}$ „idegen szellemtől" tartózkodás mintegy tanácsként jelenik meg mindenki számára, aki egy ilyen munkára vállalkozna. Ugyanakkor Arany, aki a nemzeti irodalom hagyományközösségi rendszerének volt a kiteljesítője Kölcsey Ferenc és Erdélyi János nyomán, ${ }^{73}$ az élő hagyomány, annak folytonosságát rendkívül fontosnak tartja.

A naiv eposz hiánya honfoglalási hősköltemények írására ösztönözte a magyar szerzőket: Arany hozzákezdett a hun-trilógiához, melyből azonban csak az első, a Buda halála készült el. ${ }^{74} \mathrm{~A}$ korábban már publikált múeposzokból azonban, mint például Vörösmarty Zalán futásából, legföképpen azt hiányolták a kritikusok, hogy a szerző „elmulasztá (...) jellemezni a nemzetet is, mert ősi, régi szokások, főleg a szent dolgokkali bánás teljesen mellőzve, vagy legfölebb csak említve"75 voltak. A fiatal Toldy Ferenc Vörösmarty egyéni mitológiateremtésével értett egyet, és ahogyan Szajbély Mihály megállapítja, Toldynak „minden bizonnyal eszébe sem jutott, hogy az eredeti nemzeti maradványok felkutatását és a hozzájuk való ragaszkodást kérje számon Vörösmartyn." ${ }^{16} \mathrm{~S}$. Varga nemzetfogalmaihoz

\footnotetext{
${ }^{72}$ ARANY 1962a: 264., 272., 270.

${ }^{73}$ Vö. S. VARGA 2005a: 236-259.

${ }^{74}$ Gulyás Pál egyik 1937-ben írt tanulmányában például Arany Toldiját tartja a magyar nemzeti eposznak. Vö. GULYÁS 1937: 66.

${ }^{75}$ ERDÉLYI 1886: 239-240.

${ }^{76}$ SZAJBÉLY 2005: 407.
} 
visszatérve, Toldynak - a nemzeti irodalom eredetközösségi rendszere kifejlesztőjeként ilyesmi nem is juthatott eszébe, hiszen ő Vörösmarty egyéni esztétikai teljesítményét értékelte az eposzban. Virányi Elemér majd száz évvel később egy - a Kalevaláról szóló - írásában a finn eposzt éppen Vörösmarty mưvével hasonlítja össze, és ő is a sajátos mitológiateremtést, az egyedítést tartja a mü legfőbb értékének. Azonban arra is felhívja a figyelmet, hogy a nyugati hálótól eltérő megvalósítások, ha azok mögött nincs a hagyományozás folytonossága, nem elég a nemzeti nagyelbeszélés feladatának betöltéséhez: „Vörösmarty rendkívül merész kézzel nyúlt a Zalán futásának megírásához: teljesen szakított a görög-latin vagy az újkori keresztény eposzok (Tasso, Zrínyi) hitvilágával. Végtelenül jellemző módon, a Mátra és a Bükk ormait választotta a magyar Olimposz színteréül s megteremtette a pogány magyar mitológiát. (...) Az önmaga erejére utalt Vörösmarty is bátran elmondhatta: A semmiből egy új világot teremték!"77 A Kalevala esetében is éppen ezt a közös kulturális emlékezetre alapozást emeli ki Vörösmarty munkájával szemben. ${ }^{78}$ Ezzel a gondolattal Virányi egyértelműen a hagyományközösségi irodalmi részrendszerhez kapcsolódik.

Arany a Széptani jegyzetekben az eposszal szemben támasztott formai és tartalmi követelményeket fogalmazza meg. A példák felsorolásánál ott találjuk a Kalevalát is. ${ }^{79}$

$\mathrm{Az}$ eposz cselekményszervezésében az ősi életforma bemutatása mellett a csoda megjelenése is fontos volt. Gyulai Pál is egyértelműen a mítosz és a történet kettőssége mellett foglal állást. „mythosz és történet összefolyt ködében csodás világításban emelkedtek ki előtte [a nép előtt, aki megteremti az eposzt] az istenek és hősök alakjai." ${ }^{80}$ A 1850-es évekre azonban annyiban változtatott álláspontján, hogy többekkel együtt a nemzeti nagyelbeszélést nem az eposzban, hanem a történelmi regényben vélte megvalósíthatónak. A Széptani jegyzetekben Arany is úgy ír a regényről, mint amit „,a költői előadás legkorlátlanabb formájának" tart, s melyet az "újjkor eposzának szoktak mondani" ${ }^{81} \mathrm{~A}$ finn irodalmi rendszerben éppen a Kalevala megjelentetése tette fölöslegessé a hagyományteremtésnek a romantikus történelmi regénnyel való biztosítását. ${ }^{82}$

\footnotetext{
${ }^{77}$ VIRÁNYI 1940: 4.

${ }^{78}$ Legalábbis a Lönnrottal való összehasonlításból ez olvasható ki. Lönnrotot szerencsésebbnek tartja, mivel a hagyomány „szervesebben összefüggő és költői szépségekben eredeti módon gazdag szövedékére bukkant, mind a régi írásokban, mind pedig a nép ajkán élő dalokban." Uo.

79 „A velünk újabb időben rokonságba hozott finnek is birnak ily eposszal, melynek címe: Kalevala." ARANY 1962b: 549.

${ }^{80}$ Idézi Gyulait DÁVIDHÁZI 1998: 67.

${ }^{81}$ Uo. 554.

${ }^{82}$ Vö. IMRE 2002: 95-99.
} 
A magyar nemzeti nagyelbeszélésként funkcionáló müvel vagy müfajjal szemben a 19. század végére olyan „,szigorú, régi és új” követelményeket támasztottak, melyek „közül az elavuló eposz jóformán csak a régieknek tudott volna eleget tenni, a történelmi regény pedig legföljebb az újak némelyikének. Olyan müfajra volt szükség, amely egyszerre transzcendens és világi, fenséges és okadatolható, eredetmonda és fejlődéstörténet." ${ }^{183}$ Dávidházi Péter úgy látja, hogy ezt a nemzeti eposz hiányából fakadó űrt és annak bizonyos funkcióit a 19. század végére „egy tudományos elbeszélés, az irodalomtörténeti fejlődésrajz veszi át (...) a transzcendens igazolású közösségi eredetmonda funkcióját a szépirodalom prózai elbeszélésfajtáinak nem kellett átvenniük az anakronisztikussá vált eposztól. Megtette azt helyettük a nemzeti tudomány, főként az irodalomtörténet-írás." ${ }^{84} \mathrm{~A}$ magyar regénynek - sajátos típusaival és altípusaival -, ha nemzeti nagyelbeszélésként nem is, de a „hazai eszmei, erkölcsi, nemzeti feladatokat” sikerült ellátnia. ${ }^{85}$

\subsubsection{Nemzetfogalmak és a finnugor nyelvrokonsághoz való magyar viszonyulás}

A rendi nemzeteszme egyik sajátosságaként tartották számon annak a finnugor nyelvrokonítással szembeni fellépését. Margócsy István azonban éppen arra hívja fel a figyelmet egyik tanulmányában, hogy a rendi nemzeteszme nemesi történetszemléletének leredukálása a magyar-finn (-lapp) nyelvrokonítással való radikális szembeállításra egyfelől sokkal bonyolultabb probléma, másfelől pedig nem is felel meg a valóságnak. A nyelvrokonságot elvetők, mint például Bessenyei, legfőképpen a nemzetkarakterológiai jegyek alapjáról kiindulva tiltakoztak. Margócsy úgy látja, hogy ez a szemlélet a 19. század végi ugor-török háború viszonyainak a történetietlen visszavetítése anyagában, módszerében és szemléletében egyaránt. Hiszen, amint megállapítja, már a 18. században igen nagy elterjedtségnek örvendett a finnugor rokonság téziseinek elfogadása. ${ }^{86}$

${ }^{83}$ DÁVIDHÁZI 1998: 67.

${ }^{84}$ Uo. 74-75.

${ }^{85}$ IMRE 1996: 206.

${ }^{86}$ „,....a korabeli értelmiség Sajnovics könyvét és felfogását, úgy tetszik, a Bessenyei-Orczy kör nyomtatásban csak későn megjelent tiltakozása mellett, elsősorban dicsérőleg és javallólag vette tudomásul, s a nyelvrokonítás körének kibővítését egyáltalán nem vetette el. A társ jezsuiták, Faludi Ferenc, Molnár János örvendezése mellett ide sorolható pl. a történész Pray Györgynek, Palma Károly Ferencnek, az irodalomtörténész Horányi Eleknek, Wallaszky Pálnak, az orvos Kibédi Mátyus Istvánnak, a nyelvész Benkö Józsefnek, Sándor Istvánnak, Verseghy Ferencnek, később Gyarmathi Sámuelnek és Révai Miklósnak egyetértése, vagy különös súllyal a hun-avar rokonság egykori nagy hívének, Kalmár Györgynek elfogadó nyilatkozata; a mai értelemben vett szépírók közül Virág Benedeknek dicshimnusza vagy 
Az eredetközösségi elven alapuló nemzetfogalom, mivel az államközösségivel éppen a nyelvkérdés állította szembe, a magyar nyelvet központi nemzetmeghatározó jegyként kezelte. Ebbe a nyelvhez való viszonyulásba pedig a magyar finnugor nyelvcsaládba tartozása is beletartozott.

A hagyományközösségi elven alapuló nemzetfogalom képviselőinek viszonyulása a finnugor nyelvrokonsághoz láthatatlan, megfoghatatlan volt. Nem kérdőjelezték meg, de nem is foglaltak állást mellette. Többnyire tényként kezelték. ${ }^{87}$

A nyelvrokonság elfogadásának és elterjedésének egyik módja a hunmagyar és avar vagy éppen a héber nyelvrokonsággal való összeegyeztetés volt. Ugyanez a kiterjesztő módszer jellemző a 19. század végére vagy a 20. század elejére és a két világháború közötti időszakra. Gyakorlatilag csak a kiterjesztés tere változik: az 1800-as évek végén az urál-altáji, az 1900-as években pedig a turáni nyelvekre. A finnugor nyelvészet is az egyetem keretein belül az Altaji összehasonlító nyelvtudomány tanszéke néven kezdte meg működését 1872-ben Budenz József professzor irányításával.

A turáni megnevezés Max Müller angol nyelvésztől ered, aki 1861-ben ezen a néven foglalta össze Európának és Ázsiának minden olyan agglutináló nyelvét, amely nem indoeurópai és nem sémi. Müller két nagy csoportra vélte feloszthatónak a nyelveket: a letelepült és nomád népekére. Ez utóbbit nevezte turáninak. Ebbe a meglehetősen tág kategóriába egyaránt belefértek a finnugorok, a török-tatár, a szamojéd népek vagy éppen a japánok, tibetiek ${ }^{88} \mathrm{~A}$ magyarokkal együtt az észtek sem idegenkedtek a finnugor rokonság körének tágításától, finn részről az altáji és turáni fogalmak implikálta török-tatár és mongol rokonságot meglehetős ellenérzéssel fogadták. ${ }^{89}$

A turanizmust Magyarországon különféle - profiljukat tekintve leginkább kulturális - társaságok népszerüsítették. Természetesen a kulturális vagy később gazdasági kapcsolatok célterületei nyelvészeti alapon kerültek kiválasztásra. A turániság eszméjét képviselőket azonban nem lehet és

Dugonics Andrásnak sok éven át folyó, felbecsülhetetlenül nagyhatású regénypropagandája, a 90-es évek röpirat-irodalmából Báróczy Sándornak és kivált Decsy Sámulnek javallása..." MARGÓCSY 1998: 133.

${ }^{87}$ Lásd pl. Arany már idézett sorait: „A velünk újabb időben rokonságba hozott finnek is birnak ily eposszal, melynek címe: Kalevala." ARANY 1962b: 549. [kiemelés tőlem, V. P. I.]

${ }^{88}$ Vö. KINCSES NAGY 1991: 44-49. és EGEY 2002.

${ }^{89}$ Észtországban a szűkebb - finnugor - rokonság eszméje nemcsak gondolati síkon éreztette hatását, hanem a gyakorlatban is: az I. világháború után függetlenné vált országban például a Tartui egyetem betöltetlen tanári állásaiba többnyire finn professzorokat hívtak meg, és emellett magyarokat is: Csekey Istvánt, Haltenberger Mihályt és Jakó Gézát. A nyári mezőgazdasági idényben pedig finnugor származású vendégmunkásokkal igyekeztek megoldani a munkaerő pótlását. (Vö. EGEY 2002: 41., 64.) A finnugor nyelvrokonsághoz való magyar viszonyulásról lásd bővebben a következő fejezetet. 
szabad egységesként kezelni. Az egyre-másra alakuló társaságok között voltak mérsékeltebb és radikálisabb elveket vallók is..$^{90}$

1910-ben alakult meg a Turáni Társaság (alcímében Magyar Ázsiai Társaság), melynek programjában a Társaság elnöke, Paikert Lajos a kulturális és tudományos kapcsolatok fejlesztésére helyezte a hangsúlyt: „Célunk (...) az ázsiai és velünk rokon népek, európai népek tudományát, művészetét és közgazdaságát tanulmányozni, ismertetni, fejleszteni és a magyar érdekekkel összhangba hozni... A Társaság altruisztikus irányú működéséből kizárja a politikát." ${ }^{\prime 91}$ Az 1910-es indulást követően a világháborúhoz közeledve azonban a kulturális és tudományos kapcsolatok helyett egyre inkább a gazdasági kapcsolatok kezdtek dominálni. Az 1910-ben megfogalmazott célokhoz az I. világháború alatt tapasztalható csupán visszatérés, immár a Magyar Keleti Társaság - alcímében Turáni Társaság - égisze alatt. A fordulópontot az 1920-as év jelenti, amikor két új szervezet is a turániság eszméjének továbbvivőjeként határozza meg önmagát: a Kőrösi Csoma Társaság ${ }^{92}$ és a Magyarországi Turáni Szövetség. ${ }^{93}$ Ez utóbbinak már induló programjában is a kulturális és tudományos kapcsolatok mellett hangsúlyosan szerepel a gazdasági kapcsolatok kialakítása és ápolása: „fajiságunk tudatának kifejlesztésével a magyarság erkölcsi és anyagi alapjának megerősítése, a rokon turáni népekkel a művelődés és gazdaság terén kapcsolat megteremtése." ${ }^{94}$

A 20-as években újra fellendülő kulturális és tudományos alapokon nyugvó turániság-eszme, főként a Magyarországi Turáni Szövetség tevékenysége révén, egyre inkább a politikai jobboldal, majd a szélsőjobb eszméiben talál visszhangra. ${ }^{95}$ Ennek következtében a 30-as évekre már nem a nyelv vagy a kultúra rokon vonásai kerülnek előtérbe a turáni népek kapcsán, hanem a fajiság, a vérrokonsági kapcsolat.

Bár a finnek következetesen elzárkóztak a turániság eszméjétől, a finnugor rokonság propagálásában a 20. század első felében Finnországban is - amint azt már az előző fejezetben is láttuk - a fajiság, vérrokonság és a törzsi gondolat nyert egyre inkább teret.

\footnotetext{
${ }^{90}$ A turanizmust képviselő társaságokról bővebben lásd még SZENDREI 2008.

${ }^{91}$ Idézi Paikert KINCSES NAGY 1991: 45.

${ }^{92}$ A Turáni Társaságon belül létrejött független tudományos társaságról van szó, melynek elnöke Teleki Pál, alelnöke a finnugrista Szinnyei József, titkára pedig Hóman Bálint, a majdani oktatásügyi miniszter. A Társaság folyóirata a Körösi Csoma Archívum, mely a Turán folyóirat folytatásának tekinti magát.

${ }^{93}$ A szövetség élén Cholnoky Jenő nagyvezér és Baráthosi Balogh Benedek szövetségnagy áll. A szövetség folyóirata a Kelet címü lap.

${ }^{94}$ Idézi KINCSES NAGY 1991: 47.

${ }^{95}$ Főként a Magyar Turáni Társaság tagjai közül többen is kötődtek a szélsőjobbhoz. Vö. SZENDREI 2008: 124 .
} 


\subsubsection{A magyarság önképe a 19. század végén és a 20. század elején}

A magyarság önképe mint harcos, lovas nép ${ }^{96}$ nemcsak a 18. században, hanem később is él. A régi dicsőség ösztönző hatására az 1848-1849-es szabadságharc leverése után is „,szinte kizárólag a katonai siker, a szabadságharc büvöletében él" ${ }^{97}$ A trianoni békeszerződés után, az 1920-30-as években a néprokonsági munka felvirágzása idején, a rokon észtek vagy finnek ezen az alapon tartják ezt a magyarok meghatározó jegyének, és nevezik a magyarokat „,a szabadság lánglelkű lovagjainak”.

Az 1930-as évek második felében két kötet is foglalkozik a Mi a magyar? kérdéssel: a Szép Szó 1937-es különszáma, mely a finnugor rokonságot nem érinti, és a Szekfü Gyula szerkesztésében megjelent kötet. ${ }^{98}$ Különösen ez utóbbi váltott ki nagyobb visszhangot. A kötet célja az volt, hogy objektív, "lírai magyarságvízióktól" mentes képet nyújtson a „magyarság lényegé-

96 „1. vitéz nemzet, 2. felemelkedett fejü, büszke, 3. nem tsüggedő, fel nem fúvalkodó, 4. ámbár bárdolatlan, goromba, mégis magában egyenes és jó szívü, 5. magának való, idegennek nem baráttya, 6. hogy kegyetlen, ez nem tagadható, de ez az akkori háborús időknek geniusának köszönhető"” Teleki Lászlót idézi MARGÓCSY 1998: 138.

${ }^{97}$ IMRE 2005: 233.

${ }^{98}$ Mi a magyar most? - 1937 (újranyomva: Cserépfalvi - Gondolat - Tevan. Budapest. 1990). A kötet szerzői: József Attila, Ignotus Pál, Gáspár Zoltán, hevesi András, Fejtő Ferenc, Németh Andor, Bóka László, Nagy Lajos, Horváth Béla, Simándy Pál, Kemény György, Adorján János, Takács József, Ákos László, Szvatkó Pál, Reményik Zsigmond; Mi a magyar? Szerk. Szekfü Gyula, Magyar Szemle Társaság. Budapest. 1939. (repr. 1992). A kötet szerzői: Babits Mihály, Bartucz Lajos, Echardt Sándor, Farkas Gyula, Gerevich Tibor, Kerecsényi Dezső, Keresztury Dezső, Kodály Zoltán, Ravasz László, Szekfü Gyula, Viski Károly, Zolnai Béla, Zsirai Miklós. Mi a magyar? címmel 2005-ben is napvilágot látott egy kötet Romsics Ignác és Szegedy-Maszák Mihály szerkesztésében (Habsburg Történeti Intézet. H. n.). az előszót jegyző Gerő András a kérdésfeltevést egyrészt az 1939-es kötettel való szembenállással indokolja: „Nem azért tettük, hogy a folytathatatlant folytassuk. Nem azért tettük, mert bármifajta szellemtörténeti reinkarnációban gondolkodnánk. Nem azért tettük, mert az ott közölt szerzők gondolatainak feltétlenül mai érvényességet tulajdonítanánk. Nem azért tettük, mert zsinórmértéknek tartanánk az akkori kötetet." Gerő már az előszóban leszögezi, hogy „a magyar mint fogalom, nem egyszerüen állami, állampolgári, hanem kulturális közösség". (GERỎ 2005: 8-9.) A kötet szerzői (Andrásfalvy Bertalan, Bálint Csanád, Esterházy Péter, Fejtő Ferenc, Grendel Lajos, Kányádi Sándor, Kornai János, Korniss Péter, Marosi Ernő, Ormos Mária, Romsics Ignác, Somfai László, Szegedy-Maszák Mihály, Végel László) éppen ezért a „honi és a kisebbségi magyar lét spektrumát" is reprezentálják. 2008-ban pedig Stockholmban jelent meg Dávid Gyula és Veress Zoltán szerkesztésében egy hasonló tematikájú kötet, mely a Kik vagyunk és miért címet viseli. Alcíme pedig: Irások az identitásról. A szerkesztő Veress Zoltán így ír a kötet célkitüzéseiről: „Nem titkoltuk, sőt amikor és ahol lehetett szóba hoztuk, hogy (...) magyar sorskérdésekkel akarunk foglalkozni (...). A magyar identitás kérdését ilyen sorskérdésnek érezzük." (DÁVID - VERESS 2008. 9.) A kötetben olvashatunk Kárpátalján, Erdélyben, Svédországban élő magyarokról, Magyarországon élő zsidókról, erdélyi szászokról. Ugyanakkor helyet kap a kötetben egy, a finnugor szolidaritásról szóló tanulmány is. Lásd SZÍj 2008: 299-322. 
ről”, ezen túlmenően pedig irányadónak szánta a történész szerkesztő: „Valami normafélének szántuk ezt a könyvet, hogy öntudatossá tegye az emberekben magyarságukat és megóvja őket a tévelygésektől, az illúzióktól, az ingoványba süllyedéstől." ${ }^{\prime 9} \mathrm{Nem}$ a mi-ők dichotómiában próbálták megfogalmazni azt, hogy mi a magyar, hanem a különböző tudományterületek vizsgálatából kirajzolódó nemzeti jellemvonásokból véltek egy egységesebb képet kialakítani arra nézve, amivel „a nemzeti életben is számolni lehet". A kötetben található nyelvészeti indíttatású tanulmány szerzője a finnugor nyelvészettel foglalkozó Zsirai Miklós, aki 1939-ben a Finnugor Tanszék vezetője volt. Magától értetődő elvárás tehát, hogy a szerző a magyar-finn nyelvrokonságot is érintse, amikor a nyelven keresztül keresi a választ a mi a magyar? kérdésre. Azonban nem ez történik! Aligalig utal a nyelvrokonság tényére. ${ }^{100} \mathrm{~A}$ zárómondatok pedig a nyelv sajátos szerepét hangsúlyozzák a nemzeti identitás konstruálásában: „Bástyánk, lélekgyepünk, védelmi rendszerünk, hódító hadseregünk; szent kapunk, amely kizár és befogad, menedéket nyujt és otthonunkat jelzi. Nincs nemzeti vallásunk; múvészetünk, tudományunk és jogrendünk éppúgy Európáé, mint a mienk, egyedül a nyelvünk a mi külön sajátunk és senki másé. Ezt beszélni és mívelni: az igazi Ars Hungarica."101

Zsirai Miklós hozzáállása annál is meglepőbb, mivel - amellett hogy finnugor nyelvészettel foglalkozik - az 1930-as években, a kötet megjelenése idején a finn-magyar kapcsolatok, a nyelvrokonság gondolata a közgondolkodás része volt, széles tömegeket foglalkoztatott. Sem azelőtt, sem pedig azt követően nem volt akkora bázisa a nyelvrokonság gondolatának, mint éppen akkor.

${ }^{99}$ SZEKFÚ 1992 [1939]: 8.

${ }^{100}$ Ami van, az is inkább egyedítő, a magyar-finn nyelvrokonságot lényegtelenítő: „,...a palato-veláris elkülönülés tán a finnugor alapnyelvből szállt reánk örökségül, esetleg csak különéletünk kezdő szakaszában fejlesztettük ki. Ezúttal ez másodrendű kérdés." ZSIRAI 1992 [1939]: 199.

${ }^{101}$ Uo. 216. 


\subsection{A nyelv- és/vagy néprokonságon alapuló magyar-finn kapcsolatok}

A magyar-finn kapcsolatok három csoportba sorolhatóak:

- hivatalos, államközi egyezményekkel szentesített

- félhivatalos, különböző kulturális, néprokonsági eszmét felkaroló társaságok közötti

- nem-hivatalos, személyes barátságokon vagy szakmai érdeklődésen alapuló

A személyes kapcsolatok már a 19. században Reguly Antal finnországi útjával elkezdődtek. A felsorolt három csoport között sok az átfedés és a párhuzamosság, valamint a kezdeti személyes kapcsolatok fokozatosan alakultak át félhivatalos, majd hivatalos kapcsolatokká.

Amint a hipotézisekben is már volt szó róla, feltételezésem szerint a két kulturális rendszer viszonyában a finnugor nyelvrokonságon vagy éppen néprokonságon alapuló magyar-finn kapcsolatok meghatározónak bizonyulnak, és hatással vannak a finn eposz magyar fogadtatására is. Különösen a két világháború közötti és a II. világháború alatti időszakról feltételezhető ez, hiszen az 1930-as években Vikár Béla fordítása négyszer is megjelent gyors egymásutánban.

A következőkben ennek az időszaknak a hivatalos és félhivatalos, majd az 1950-es évektől napjainkig tartó időszak hivatalos kapcsolatait tekintem át.

\subsubsection{Félhivatalos kapcsolatok: a néprokonsági munka}

A 19. század egyéni kapcsolattartásai után valamiféle intézményesülésről már az 1910-es évtől kezdődően beszélhetünk, gondoljunk a Turáni Társaság megalapítására. Az 1921-es év egyfelől az első magyarországi magyar-finn-észt társaság, a rövid életű Magyar-Észt-Finn Ifjúsági Egyesület magyar osztálya megalakulásának az éve, másfelől pedig a Helsinkiben rendezett első finnugor kultúrkongresszus éve, melyet az 1924-es tallinni és az 1928-as budapesti követett. A finnországi kultúrkongresszus megszervezésében az 1906-ban alapított Suomalaisuuden Liitto (Finn Nemzeti Szövetség) nevü szervezet vállalt oroszlánrészt. A szervezet tevékenységi körébe ezenkívül magyarországi egyetemi hallgatók és tudósok finnországi útjának támogatása is beletartozott, ${ }^{102}$ vagy olyan magyar nyelvü,

102 Támogatta többek között Teleki Pál majdani miniszterelnök finnországi útját, az egyesület által szervezett előadásokon pedig olyan személyiségek adtak elő politikáról, a trianoni békeszerződésről vagy nyelvészetről, mint a Kalevala-fordító Vikár Béla, a helsinki egyetem magyar lektora Weöres Gyula vagy a nyelvész Zolnai Gyula. Vö. TAKALO 1986: 185-186 
Finnország ${ }^{103}$ címü folyóirat indítása, melynek segítségével a finn kultúrát szándékoztak Magyarországon bemutatni. A két világháború között és a II. világháború alatt olyan háromnyelvü - magyar, finn és észt - folyóiratokat, évkönyveket is kiadtak, mint a Fenno-Ugria, ${ }^{104}$ Heimokansa $^{105}$ vagy Heimotyö, ${ }^{106}$ melyek Finnországban jelentek ugyan meg, de Magyarországra és Észtországba is eljutottak. A folyóiratok cikkeiben a háború közeledtével egyre inkább a nyelvrokonságon alapuló közösségvállalás szükségessége és a veszélyérzetből fakadó szovjetellenesség volt tetten érhető. A Fenno-Ugria 1925-ös első számában a programadó cikk (három nyelven) így írt erről: „Miután az erőviszonyok világháború okozta eltolódása következtében Finn- és Észtország fölszabadult és az Osztrák-Magyar Monarchia felbomlása révén Magyarország - tragikus földarabolásától eltekintve - zavaró hatásoktól mentes állami életét megkezdette, a rokonsági eszme mind egymás, mind más finn-ugor népek iránt hatalmas erővel lobbant a szívekből elő mindhárom független finn-ugor ország területén. Így történt akkor is, amidőn e népek mindegyike súlyos nehézségei és fenyegető ellenségei közepette jóbarátok szerzésének szükségességét és kilátásait fontolgatva saját rokonságát is szóba hozta. De így történt azért is, mert önálló életet élve a vérségi kötelék természetes jogaikhoz és lehetőségeikhez az utat könnyebben megtalálták. (...) A Fenno-Ugria látja nagy és fölötte nehéz teendőit és hivatása szerint megkísérli, hogy a finn-ugor népek szellemi horizontját sajnálatosan szétszóródott egész finn-ugor fajunkra kiterjessze, lelküket közös távlatok befogadására képesítse és fölemelje őket kulturális tényezőkké a harcvonal legélére, ahová a történelem vezényszava rendelte őket. Erre törekszünk: amit megtehetünk, meg fogjuk tenni."107 Ezt a finnugor népek kulturális egységéról írott cikk követte, melyben egyértelmúen az ellenséggel (jelen esetben a szovjet bolsevizmussal) való együttes szembenállás szükségességét emeli ki a szerző: „,nekünk, finn-ugor népeknek, két közös tulajdonunk van: az egyik aggodalommal tölt, a másik reményekre jogosít bennünket a jövendőt illetőleg. Az egyik az égető közös veszély, a másik a finn-ugor ősök magasztos lelkülete. (...) Az állami és kulturális orientálódás egymással való szoros összefüggése azonban nyil-

\footnotetext{
${ }^{103}$ Az 1942 és 1943-ban megjelenő Finnország a Suomalaisuuden Liitto magyar nyelvű folyóirata. Három száma jelent meg. Főszerkesztője V. A. Heiskanen.

${ }^{104}$ A Fenno-Ugria első száma 1925-ben jelent meg Helsinkiben a Suomalaisuuden Liitto néprokonsági osztályának kiadásában. Három nyelvű - finn, magyar, észt - lap. A szerkesztőbizottság magyar tagja Faragó József. Negyedévenként megjelenő folyóiratnak szánták, mely 32 oldal terjedelemben, lehetôség szerint illusztrálva jelenik meg.

${ }^{105}$ A Heimokansa - Testvérnép 1941-1944 között jelent meg. Szerkesztője: Frans Akseli Heporauta és Túróczy Zoltán. A cikkek mellett magyar és észt nyelvleckéket is tartalmazott.

${ }^{106}$ A Heimotyö a finnugor bizottság finn osztályának évkönyve.

${ }^{107}$ A szerkesztők az olvasóhoz Fenno-Ugria 1925/1 4., 6. [kiemelés tőlem, V. P. I. - A finn nyelvű szövegben ez nem szerepel.]
} 
vánvaló jelen esetben már csak azért is, mert a finn-ugor népek egyesítése végett feltétlenül szükséges a közös kulturális kötelékek megszilárdítása, hogy megkovácsolhassuk azon acélpatkót, amelybe ősi ellenségünket be kell szorítanunk, ha fajunk élni akar." ${ }^{108}$ A „,keleti szörnyeteg” elleni közös harc igézetében a magyarok és finnek egymáshoz való viszonyulására az idealizált és sztereotipizált jellemvonások egymás mellé sorakoztatása volt jellemző. A finnek a magyarokban a „hazaszeretet lánglelkủ lovagjait” és a "daliás rokont" látják. ${ }^{109}$ Magyarországon különösen a finneknek a szovjetek ellen folytatott Téli-háborúja alatt kapott föszerepet a finnek iránti csodálat hangja. A rokonság szellemében a finnek hősies helytállását magyar nemzetiségü önkéntes katonák is segítették. ${ }^{110}$

\footnotetext{
${ }^{108}$ PESONEN 1925: 15-21.

${ }^{109} \mathrm{Az}$ elragadtatott nyelvhasználat és a csodálat hangja, valamint a magyarokkal való együttérzés általános ezekben a folyóiratokban. Ilyen a Fenno-Ugria 1925/2-es számában közölt, a második finnugor kongresszuson, Tallinnban elhangzott Gustav Ollik beszéde: „Üdvözöllek benneteket, Magyarország fiai és leányai! Büszkék lehettek ezeréves múltatokra! Büszkék lehettek arra, hogy ezer éven keresztül védelmeztétek Európa kultúráját. Ti vagytok a hazaszeretet lánglelkü lovagjai. Isten hozott benneteket daliás rokonaink! A sors szép hazát adott számotokra, de a szenvedésekből is kikaptátok a részeteket. A támadásra készülő sebesült oroszlán Magyarország tartalmas szimbóluma. Bízunk Vörösmarty szavaiban: „Még jőni kell, még jőni fog egy jobb kor, mely után buzgó imádság epedez százezrek ajakán." Ha a testvéri kézszorítás balzsam, mely a fájdalmat megenyhíti érzelmeinket küldjük Golgotán szenvedő testvéreink felé. Hiszünk szilárdan Magyarország föltámadásában. Hisszük, hogy jobb jövő várja azt a népet, amelynek nagy államférfiai, tudósai és múvészei és a testvéri szeretet orvosság, mely a sebeket behegeszti, akkor kitárjuk mindkét karunkat ölelőre és legszebb magas teljesítményekkel gazdagították az emberiség kultúráját." (104.) vagy a Heimotyö második számában (1938-39) Väinö Musikka írásában: [eredeti szöveg:],,suomalaiset, eestiläiset, magyarit, koko suomalais-ugrilainen suuri heimoyhteys! On ihanata ajatella, että olemme yksilöitä tästä monivivahteisesta kansojen erikoisryhmästä. Suomalaisten kestävyys ja sisu, eestiläisten sitkeys ja herkkyys, unkarilaisten tulisen luja tahto - ne kaikki ovat ominaisuuksia, jotka vievät eteenpäin itsekutakin näistä kansoistamme ja samalla myöskin koko ihmiskunnan pyrkimyksiä. ... »Me uskomme kansalliseen ylösnousemukseen«, tämä unkarilaisten tulevaisuudenvala on ollut aikojen kuluessa näille kaikille kansoille yhteinen. Tervehdimme teitä kaikkia, tätä heimolaisuutemme kolmiyhteyttä uskoen ja luottaen suureen tulevaisuuteemme.” [magyarul:] „finnek, észtek, magyarok, nagy finnugor törzsközösség! Csodálatos dolog arra gondolni, hogy egyediek vagyunk a népeknek ebben a színes csoportjában. A finnek kitartása és szívóssága, az észtek keménysége és érzékenysége, a magyarok lángolóan szilárd akarása - ezek mind olyan tulajdonságok, melyek előre viszik nemcsak népeinket, hanem ugyanakkor az egész emberiség törekvéseit. »Hiszünk a nemzeti feltámadásban«, ez a magyarok jövőre vonatkozó fogadalma az idők folyamán minden népnek közös fogadalmává vált. Üdvözlünk hát titeket, hiszünk a törzsi szentháromságban és bízunk a fényes jövőnkben." [fordítás tőlem, V. P. I.] MUSIKKA 1939: 73-74.

${ }^{110}$ A magyar nyelven megjelenő Finnország címú folyóirat programadó cikke sem feledkezik meg erről, de sokkal inkább kulturális és gazdasági téren képzeli el a további együttmúködést: „A magyar-finn kultúrkapcsolatok szorosak. Azokat rokoni és vérközösségi kötelékek erősítik. Ideális alapon eddig is számosan dolgoztak rokonságunk népszerüsítéséért és fognak dolgozni a jövőben is. De most itt az ideje annak, hogy a finn-magyar rokonsági gondolat szerepet követeljen magának nemcsak eszmei, de gyakorlati téren is. Hogy az ed-
} 


\subsubsection{A magyar-finn kapcsolatok intézményesülése}

1937. október 22-én írták alá a két állam képviselői az első magyar-finn államközi kulturális egyezményt, mely a kapcsolatok elmélyítését és intézményessé tételét fogalmazta meg célként. ${ }^{111} \mathrm{Az}$ egyezmény 16 cikkelyéből négy - a legrészletesebben kidolgozottak - a rokonsági eszmén és nyelvrokonságon alapuló együttműködéssel foglalkozott. Az egyezmény aláírásakor Uuno Hannula miniszter az államközi kapcsolat szükségességét éppen a nyelvrokonsággal (néprokonság?) motiválta: „Azok a kapcsok, melyek bennünket összekötnek, a messzi múltig nyúlnak vissza. A magyar nyelv vér és a finn nyelv veri szava bizonyítja, hogy vérségi kapocsról van szó, melyet az eltelt évezredek sem tudtak szétszakítani. Ezeket a szent kapcsokat óhajtjuk a jövő generáció számára is megőrizni." ${ }^{112}$ Ugyancsak 1937-ben, az államközi szerződés aláírása előtt röviddel alakult meg a Magyar-Finn Társaság, ${ }^{113}$ melynek fő célkitüzése a finn kultúra magyarországi megismertetése volt.

digi előkészítő korszak lezárult és a finn-magyar rokonsági munka új fázisába lépett, azt az 1939-40-es orosz veszély ránk zúdulásakor Finnországnak küldött segítség bizonyítja, melylyel Magyarország hitet tett a népeinket egybefüző sorsközösségről és együvé tartozásról. A folytatólagos és eredményeket hozó munkának azonban előfeltétele, hogy egymás életkörülményeit, viszonyait, a párt- és napi politika célzatosságaitól mentesen, a valóságnak megfelelően megismerjük. Az országainkat elválasztó földrajzi távolságot legegyszerűbben ismertető szak- és szépirodalom terjesztésével csökkenthetjük. Evégből szükségünk van jó magyar szépirodalomra, magyar zenére, különös tekintettel a folklórkutatás eredményeire, útleírásokra, gazdasági szakkönyvekre stb. Idegen forrásokból eredő és turisztikai érdekek terjesztette puszta, csárdás, korcsma, csikós, cigányprímás, izzó tokajerek, operettek s más hasonló kellékek romantikussá minősített Magyarországa helyett meg akarjuk ismerni végre is az igazi magyar arcot, a munkás, a dolgozó Magyarországét, annak iparát, földmívelését, bányászatát, tudományos és művészi életét stb." [kiemelés az eredetiben] Finnország 1942/1. 3.

${ }^{111}$ Egey Emese, aki doktori disszertációjában a magyar-finn diplomáciai kapcsolatokat vizsgálta a két világháború között, megállapítja, hogy a külügyminisztériumi iratok is arra utalnak, hogy Magyarország több okból is kívánatosnak és kiemelten fontosnak tartotta a kapcsolatfelvételt Finnországgal: „egyrészt Magyarország ügyének, a revíziónak támogatókat igyekeztek szerezni külföldön, másrészt közelről kívánták szemmel tartani a Szovjetunió szándékainak és erőviszonyainak alakulását." EGEY 2002: 58.

${ }^{112}$ [eredeti szöveg:] „Ne siteet, jotka meitä yhdistävät, ulottuvat kaukaiseen menneisyyteen. Unkarin kielen vér ja suomen kielen veri-sanat todistavat, että kysymys on veren siteistä, joita vuosituhansien ajatkaan eivät ole voineet katkaista. Nämä pyhät siteet tahdomme säilyttää myöskin tuleville sukupolville." Heimotyö 1938-1939: 65. [fordítás tőlem, V. P. I.]

${ }^{113}$ A Társaság elnöke, Nagy Emil volt igazságügy-miniszter, ügyvezető alelnöke Virányi Elemér, aki korábban Tartuban volt magyar lektor, főtitkára Gaskó Dezső orvos. A Turán Társasággal közösen (is) több kulturális estet és összejövetelt szervezett, önálló kiadói tevékenységet folytatott. 1941-ben négy, Finnországban müködő néprokonsági szervezettel is együttmúködési egyezményt írt alá. A négy szervezet: Helsingin Akateeminen Heimoklubi (Helsinki Akadémiai Néprokonsági Klub), Suomen Heimotyöseura (Finn Néprokonsági Társaság), Suomalaisuuden Liitto (Finnségi Szövetség), Akateeminen Karjala Seura (Akadémiai Karjala Társaság). Vö. EGEY 2002: 44-53. 
Az 1937-es év azonban korántsem jelentette a kapcsolatok kezdetét. A kapcsolatok félhivatalos és egyre hivatalosabbá váló, állami szinten is megjelenő jellegét erősítette a Klebelsberg Kunó kultuszminiszteri tevékenysége alatt, 1929-ben létrehozott ösztöndíjrendszer is, valamint az a tény, hogy a magyarországi iskolákban bevezették a rokon népek napjának - október utolsó hétvégéje - megünneplését is. Klebelsberg 1930-ban az északi államokat érintő körútján járt Finnországban és Észtországban is. Hazatérése után megalakította a Finnugor Kutatás Magyar Nemzeti Bizottságát, és ezzel az országos kultúrpolitika szintjére emelte a finnugor rokonság támogatását. ${ }^{114}$

\subsubsection{A magyar-finn kapcsolatok az 1950-es évektől napjainkig}

A második világháborút követő közvetlen időszakban a magyarországi politikai rendszer megváltozása miatt a polgári Finnországgal kialakult kapcsolatok ismét személyes vagy félhivatalos szinten müködtek. A hivatalossá válásukban direkt és indirekt módon a Kalevalának is jutott szerep.

A Kalevala jegyében történt például a kulturális kapcsolatok újrafelvétele: 1949-ben, az Új Kalevala megjelenésének 100. évfordulóján érkezett az első delegáció Magyarországról Finnországba, majd ezt követően jó néhány tudós és múvész tett látogatást a Kalevalával vagy Lönnrottal kapcsolatos jeles ünnepeken. Ugyanígy a háború után elsőként Magyarországra hívott finn tudós is a Kalevala keletkezéséről tartott előadást. ${ }^{115}$

A kapcsolatok hivatalosabbá válása 1950-ben a Finn-Magyar Társaság alapításával kezdődött. Bár a kezdetekkor politikai, gazdasági és kulturális arculattal is rendelkezett a társaság, 1957-től csak kulturális téren kívánta folytatni tevékenységét. ${ }^{116}$

Újabb kultúregyezményt a két ország 1959. június 10-én írt alá Budapesten. A finn küldöttséget Heikki Hosia oktatási miniszter, a magyar küldöttséget pedig Benke Valéria kulturális miniszter vezette. ${ }^{117}$

Az új okirat nagyon sokban hasonlított az 1937-ben megkötött egyezményhez. Ebben is hangsúlyos szerepet kapott a magyar-finn nyelvrokonságon alapuló kulturális csere. ${ }^{118}$

\footnotetext{
${ }^{114}$ A bizottság vezetői Gombocz Zoltán, majd Zsirai Miklós - a finnugor összehasonlító nyelvészettel is foglalkozó nyelvészek - voltak, szellemi központja pedig az Eötvös Kollégium. Vö. EGEY 2002: 42-44.

${ }^{115}$ Lásd KAUKONEN 1982: 21.

${ }^{116}$ Lásd bővebben VILKUNA 1967: 78-82.

${ }^{117}$ Vö. NUMMINEN 1984: 9-15.

${ }^{118}$ Vö. HUOTARI - KAUKONEN 1984: 231-239.
} 
A két ország közötti kapcsolatok hivatalossá válásával újraindult az ötévenként megrendezésre kerülő finnugor kongresszusok sorozata is. Ezek szervezésében a két ország mellett a Szovjetunió is részt $\mathrm{tt}$, lévén a harmadik olyan ország, ahol jelentős számú finnugor népesség élt, hiszen Észtország is a szovjet tagköztársaságok egyike volt.

A finnországi Finn-Magyar Társaság mintájára Magyarországon jóval később, 1989. február 28-án, a Kalevala napján alakult újra meg a MagyarFinn Társaság. ${ }^{119}$ Ekkor határozták el ugyanis a Magyarországon müködő és bejegyzett Magyar-Finn baráti körök és szervezetek, hogy egy országos szervezetben egyesülnek.

Ami a Finn-Magyar Társaságot illeti, különösen a megalapítását követő első két évtizedben, legfőképpen az akkori Magyarország propagandacéljait szolgálta. Ezt támasztja alá az a tény is, hogy a társaság elnöki tisztségének betöltésének kérdésében a magyar államnak döntési joga volt. ${ }^{120}$

Az 1959-es kultúregyezmény aláírásával az 1946-1958 közötti hallgatás időszaka után az irodalmi életben is újraindult a finn szerzők magyarországi megjelentetése. Lényegi változás azonban - Szopori Nagy szerint - leginkább a 70-es évek elején volt érzékelhető. Addig tartott ugyanis a „tapogatózás és az újrakezdés korszaka". ${ }^{121}$ A változás a finn irodalomhoz való közeledésben szemléletmódbeli változást is jelentett: egyre kevesebb utalás történt a nyelvrokonságra és a két világháború között oly sokszor hangoztatott finn-magyar párhuzam is eltünt a közbeszédbőll. ${ }^{122}$

Az 1989-es rendszerváltást követő időszak legfontosabb eseménye a magyar-finn hivatalos kapcsolatokat illetően a Finnagora 2004-es budapesti megnyitása. A Finnagora kulturális, tudományos és gazdasági központként határozta meg önmagát: „tevékenysége komoly helyismeretre és a kulturális exporttal kapcsolatos tudásra épül. A Finnagora szakmai együttmüködést és valódi kölcsönhatásokat teremt Finnország és Magyarország között. Célja Finnország, a finn kultúra és művészet, oktatás, kutatás és gazdaság ismertségének növelése Magyarországon." ${ }^{123}$

\footnotetext{
${ }^{119}$ A Társaság alapszabálya a következőképpen kezdődik: „AA magyarországi magyar-finn baráti körök a magyar-finn baráti kapcsolatok ápolása, erősítése és fejlesztése céljából, a két nép közös örökségére, hagyományos barátságára, az 1937-ben alapított Magyar-Finn Társaság céljaira is alapozva 1989. február 28-án, a Kalevala napján elhatározták, hogy a baráti körök szövetségeként létrehozzák a Magyar-Finn Társaságot." http://www.magyarfinntarsasag.hu/index.php Letöltve 2008. október 12.

${ }^{120}$ Erről lásd bővebben OIKARI 2001.

${ }^{121}$ SZOPORI NAGY - VARPIO 1990: 105.

${ }^{122}$ Lásd uo. 110.

${ }^{123} \mathrm{http}$ ///www.finnagora.hu/frameset.php Letöltve 2007. november 19.
} 
Összegzésként elmondhatjuk, hogy a két ország mindennemű kapcsolatában a nyelvrokonság meghatározó szerepet játszott. A félhivatalos vagy hivatalos kapcsolatokon keresztül közvetített kép az irodalmi művekkel szembeni elvárásokban is éreztette hatását. A finnekben a magyarokról kialakult kép, Gerevich Kopteff Éva meglátása szerint, a magyar irodalom finnországi fogadtatására is rányomta bélyegét: a magyar művekben a forradalmi gondolatot keresték. Emellett pedig úgy véli, hogy a két irodalom közötti kapcsolatra a beskatulyázás a jellemző: a finn irodalmat a magyarok a Kalevala-skatulyába helyezték, a finnek a magyarokét pedig a Petôfibe. ${ }^{124}$ Szopori Nagy ezt legfőképpen annak tulajdonítja, hogy például a nyugatosokkal alig-alig ismertették meg a finn olvasóközönséget. A leglényegesebb különbség a finn irodalom magyarországi és a magyar irodalom finnországi fogadtatása között az, hogy: „, a magyarok szívesen tekintik a finn irodalmat a finnugor népek irodalma egyikének, Finnországban viszont a magyar irodalom mint a közép-európai irodalmak képviselöje van jelen, s a finnugor népekével alig hozzák kapcsolatba". ${ }^{125}$ Ez a magyar oldalon tapasztalható - Szopori szavaival élve - „másként kezelés” rányomja bélyegét a finn irodalom magyarországi fogadtatására.

Az, hogy a Kalevala esetében is müködött-e a "másként kezelés”, vagy a finn eposz ettől eltérő, netalán kitüntetett szerepet játszott és játszik-e a két rendszer kapcsolatában, arra a következő, a magyar fordítások kritikai fogadtatását vizsgáló fejezetekben keressük a választ.

\footnotetext{
${ }^{124} \mathrm{http}$ //ethesis.helsinki.fi/julkaisut/hum/suoma/vk/gerevich-kopteff/madachaz.pdf

Letöltve 2007. március 16.

${ }^{125}$ SZOPORI NAGY - VARPIO 1990: 150-151.
} 



\section{KÉT KÍSÉRLET A FINNUGOR HÁLÓ MEGTEREMTÉSÉRE}

Azzal a megállapítással, hogy a finn eposz magyar fordításai a magyar irodalomból hiányzó nemzeti nagyelbeszélést hivatottak pótolni, én sem vitatkozom. A következőkben is ezt fogom igazolni, éppen azokat a stratégiákat vizsgálva, melyekkel ezt Barna Ferdinánd és Vikár Béla megvalósítani próbálta: a finnugor háló megteremtésével.

A finnugor háló fogalmát az első fejezetben a következőképpen határoztuk meg: olyan szövegrendszer, melyben nem a műfaj, hanem az a nyelv a meghatározó, amelyen a szövegek íródtak. A szövegrendszert pedig olyan fogalmi keret tartja össze, mely az egyedítés konstruálásának eszköze, identifikációs (segéd)eszköz, mely a különbségekre fókuszál, felerősíti azokat a másságokat, melyek a nyugati háló diktálta fogalmi kerettől megkülönböztetik és azokat a hasonlóságokat, melyek a finnugor háló megteremtéséhez szükségesek lehetnek.

\subsection{Első kísérlet - Barna Ferdinánd fordítása}

Az Új Kalevala finnországi megjelenése után Hunfalvy Pál ${ }^{126}$ és Fábián István ${ }^{127}$ is fordított részleteket magyarra az eposzból. A teljes szöveg magyarul először Barna Ferdinánd fordításában jelent meg 1871-ben, az Akadémia kiadásában.

${ }^{126}$ Hunfalvy Pál (1810-1891) nyelvész, etnográfus, történetíró. Ő kezdte el megszervezni és kiépíteni a komplex szemléletü magyar uralisztika bázisát és szervezeti kereteit. Főként a vogul és az osztják népek irodalmának népszerüsítőjeként fejtett ki aktív munkásságot.

${ }^{127}$ Fábián István - Philofennus (1809-1871) plébános, nyelvész. Az elsők között volt, aki a finn nyelvről nyelvkönyvet, az irodalomból pedig fordításokat és tanulmányokat közölt. A FIT az elsők között választotta meg külföldi tagjának. 


\subsubsection{Finnugor mitológiát rekonstruáló törekvések}

Az 1871-ben megjelent Kalevala-kötet a fordított szöveg mellett tartalmazta a fordító előszavát és jegyzeteit is. A következőkben ezeket vizsgálom a finnugor háló jellemzőire összpontosítva.

A fordításhoz írt előszó szerkezeti felépítése jól átgondolt: Barna először az eposznak a nemzeti irodalmakban betöltött szerepéről és fontosságáról ír, majd fokozatosan tér rá a magyar, finn és vogul irodalmi párhuzamokra. Az első mondatokban jó érzékkel a példaértékű és a magyar kultúrára nagy hatással levő német nemzeti irodalomra hivatkozik. A nemzeti eposzról írottak arról tanúskodnak, hogy Barna igen tájékozott a herderi és a hegeli filozófiában is. Az eposznak kettős feladatot szán: megmutatni a külvilágnak az illető nép őskorának egy szeletét, az ún. „történelem előtti” időt - „az idegenre nézve becsesek azért, mert az ős népek multjába egy-egy mély pillantást engednek vetni", ${ }^{128}$ valamint erősíteni a nemzeti tudatot: , az azon nemzetbelire nézve azonban sokkalta fontosabbak, minthogy lehetetlen képzelni is egy nemzetét szerető, emelkedett szellemü és gondolkozófőt, aki ne vágynék őseinek hitét, szokásait, erkölcseit ismerni, mintegy tükörben látni maga előtt, s hogy ugymondjam, nehány percre mintegy egészen átalakulni azzá, amik ősei voltak, ugy érezni amint azok éreztek, egy szóval támaszpontot szerezni magának azok gondolkozása biztos megitélésére." ${ }^{129}$ Éppen e kettős szerep fontossága miatt foglalkoztatja Barnát a magyar irodalomból hiányzó eposz. A hiány okai között a török hódítás, az „idegen ajkú népek” bevándorlása egyaránt szerepelnek. Következtetésében, miszerint „ma már nem is valószinü, hogy ilyesmit a nép ajkáról sikerül összegyüjtenünk", egy - korának a naiv eposzról vallott felfogásában - jól tájékozott és racionálisan gondolkodó tudós-kutató szól az olvasóhoz. A benne is munkáló vágyat, hogy a hiányzó magyar eposzt valamilyen formában pótolhassa, leginkább egy finnugor nyelven íródott, hasonló műfajú szöveg lefordításában látta kivitelezhetőnek: „ha már magunknak sem nyelvemlékeink, sem ilyen történelem előtti időre visszavezethető összegyüjtött ősköltészeti maradványaink nincsenek, önként következik, hogy a velünk rokon népek ilyennemű gyűjteményei leginkább kínálkoznak buvárlat és összehasonlítás tételére mindannyiszor, valahányszor bennünket az imént jellemeztem nemesebb vágy meglep, melyet a honfoglalást tárgyazó régi ének így fejez ki: emlékezzünk régiekről." ${ }^{130}$ Mivel Barna a nemzeti nagyelbeszélést csak az eposz műfajában vélte megvalósíthatónak, ugyanakkor felismerte a hagyomány folyto-

\footnotetext{
${ }^{128}$ BARNA 1871: IV.

${ }^{129}$ Uo. IV.

${ }^{130}$ Uo. V.
} 
nosságának fontosságát, gyakorlatilag két feladatot kellett végrehajtania: kiválasztani a lefordítandó művet és megteremteni a folytonosságot. A Kalevalát európai sikere, müfaja, megjelenésének előzményei és körülményei tették alkalmassá az egyik feladatra. A másikat pedig a rokonságon alapuló kontinuitásra hivatkozás biztosította. Alapként a finnugor nyelvrokonságnak kívánta megnyerni az olvasókat, kiemelve a finneket a finnugor nyelveket beszélők közül, és a németek mellé helyezéssel példaként állította az olvasók elé. ${ }^{131}$ Részletekbe menően írt a finn és az észt gyüjtésekről, a Kalevala és a Kalevipoeg megjelentetésének körülményeiről. A két eposz világirodalmi fogadtatásából jó érzékkel a legjelentősebbeket válogatta ki. Olyan elismert szaktekintélyekre hivatkozott, amikor a Kalevalát a klaszszikus eposzok sorába helyezte, akik egész Európában ismertek voltak és a kulturális főáram hangadóinak számítottak: „Grimm Jakabra, Steinthalra, Uhlandra, Carriére M.-ra, Schott V.-ra" ${ }^{132}$ Grimm egyike volt azoknak, amint az előző fejezetben is láttuk, akik a Kalevalát Homérosz eposzaival vagy éppen a Nibelung-énekkel helyezték egy sorba. Steinthal pedig még tovább ment, s az eposz nevet teljesen megérdemlő hőskölteménynek csak négyet ismert el: az említettek mellett a Roland-éneket és a Kalevalát.

Barna úgy próbálja a célnyelvi olvasóhoz közelebb hozni a finn Kalevalát, hogy egyfelől feltárja annak általa feltételezett magyar vonatkozásait, másfelől pedig a közös gyökerekből fakadó hasonló lelkületet vizionál. A fogalmi keret felvázolásakor - vagyis annak leírásakor, milyennek is kellene lennie a közös, finnugor (h)ősi kornak és hitnek - a finn eposz nem epikai részéből merít: Barna meglátásában Bornemisza Péter Ördögi kísértetekról című munkájában található félpogány, félkeresztény ráolvasások szövegei szóról szóra megegyeznek a Kalevala ráolvasásainak passzusaival. ${ }^{133}$ Ebből kiindulva szögezi le rögtön az előszó elején, hogy a magyarok pogány kori őshite alapjában teljesen megegyezik a finnekével.

131 „A Kalevala énekei ily valóban hangya szorgalommal történt gyűjtéséből láthatjuk először azt, hogy e gyüjtések nálok előbb megindultak, mint Európa legműveltebb népeinél, nem véve ki innen a németet sem; másodszor, hogy mennyire jóra való népnek kell egy olyannak lenni, amely egy ilyen ügyet oly jókor felkarolt, és azt azóta a legirtózatosb megpróbáltatások között sem ejtette el, megpróbáltatások közt, amelyről lehettek igen is fogalmaik őseinknek a 30 éves háborúban, melyből nekik is bőven kijutott a maguk részük és ezzel egyidejü török uralom alatt, melyhez az oroszok közvetlen szomszédsága egészen hasonló ínséget és irtó háborúkat eredményezett számokra, - de már minekünk utódaiknak alig lehet, s következőleg mennyire érdemes e derék kis rokon-nép teljes becsülésünkre s végre hogy continuitásra nemcsak a közjog terén van szükség, hanem a tudomány birodalmában is, ha sikert akarunk elérni, ennek a finnekéhez egészen hasonló szívós és szakadatlan kitartás egyetlen eszköze." Uo. XIII. [kiemelés tőlem - V. P. I.]

${ }^{132}$ Uo. IV.

${ }^{133}$ Barna Ferdinánd 1872-ben A finn költészetről, tekintettel a magyar ősköltészetre címmel erről bővebben is előadást tartott az Akadémián. 
Az előszóban és a kötet végén található jegyzetekben rendkívül hangsúlyos az ösi finn és magyar hitélet és költészet hasonlóságainak, analógiájának bemutatása. A jegyzetekben még tovább erősíti a finnugor háló megteremtésének szükségességét és létjogosultságát. A magyar-finn párhuzamok mellett a rokon népek - pl. a vogul - népköltészetéből is merít. Akár úgy is fogalmazhatunk, hogy Barna a történeti objektivitást szem előtt tartva, a jegyzetekben megjelenő etimologizálások révén egy finnugor - és ezen keresztül - magyar nemzeti mitológia megteremtésére tett kísérletet. ${ }^{134}$

A német irodalmi párhuzammal és a finn eposzról mint a nyugat-európai irodalmi életben elfogadott és csodált müről szóló beszédmóddal a nyugati hálóra reflektált, és az így ábrázolt finnekben a magyarok elé állított követendő példát. Az előszóról és a jegyzetekről összefoglalásként

\footnotetext{
${ }^{134}$ A kötet végén található jegyzetek főként egy-egy sorhoz vagy kalevalai hőshöz füződő magyarázatok. A legtöbb finn-magyar analógián alapul, célja a finnugor mitológia rekonstruálása. Ezekből a legjellemzőbbek: „1:110. az eredetiben: Ilmatár annyi mint légleány; én légtündérének fordítám, mivel ez a magyar nép felfogásának jobban megfelele; lmás (sic!) neve: víz-anya (143-164).; 1:169. Ukko, a finn nemzet fő istenségének tulajdon neve; maga a szó öreget, aggot jelent, - ma már a Hegyaljáról az Akadémiába beküldött szőlő-eladási okiratokból tudva van, hogy őseink is így hívták a magyar pogány vallás fő istenét, - kit öreg embernek képzeltek, - s a tiszteletére inni szokott áldomásoknak is Ukkon-pohara volt a neve.; 1:233-234. Az eredetiben maa-emä, magyarul szórúl szóra: föld-anya; ezen istenséget őseink szintén e néven ismerték, ami a Bornemisza Péter: »Ördögi kísértetek « című müvében fenn tartott 8 félpogány félkeresztény ráolvasás (imák) egyikében fordul elő. - A földanya a föld alatt lakónak gondoltatott; más neve föld üke (Mannun eukko) jóságos isteni lény volt.; 1:321-322. Büvölés közben a névtelen (nimetön) vagyis a negyedik ujjnak igen nagy szerepe volt, valamint a magyar népnél is némely vidékeken babonázás közben mind a mai napig. V.ö. XV. 271. s XLIII. 260.; 2:7. Sárrét, finül saari, - amint hívták őseink is a szigetet (sári); én a sárrét szót e fogalom kifejezésére Paleocapa P a Tisza-szabályozásról 1847-ben írott művéből vettem, amelyhez csatolt térképen a vízöntötte térségek így neveztetnek p. o. Sebes Körös sárrétje, és Berettyó sárrétje; amilyenek ezek a sárrétek, olyanok a finn országi szigetek.; 2:247-248. kaleva és Oszmo: egyértelmüek a főistennel, Ukkóval. A finn hitregészetnek a vogul hitregészeti maradványokkal való egybehasonlításából azonban az látszik valószínűnek, hogy kaleva a finnek nemzeti istene lett volna, akitől az egész nemzet származik, - s ez esetben ennek a »magyarok istene « fogalom felelne meg, mint saját nemzeti istenségünk, aki tehát, Ukkonnal a főistennel nem egyazon személy.; 3:131. örök fája a dallásnak: szabad fordítása a finn laulaja iän-ikuinennek. Jogosítva éreztem rá magam annál inkább, mert először: ország szerte mesefának hívják az oly embereket, akik sok mesét tudnak regélni, - másodszor mert ez a fogalom a finnben is meglehetősen honos.; 4:135-136. A nap és a holdtündére, - a magyar mesék is ismerik a napurfit, - így a finn hitregéset egyaránt a nap fiát, és a nap lányát, (tündérét). Ezek igen szorgalmas isteni lények voltak, kik a nap és hold arany és ezüst sugaraiból szöveteket szőni képzeltettek, neveik finnül: Kuutar: Holdleány, és Päivätär: Napleány. A magyar »tündér" szó értelme nem egészen bizonyos; érdekes tudni, hogy tytär finnül annyi mint leány, összetételekben azonban rövidítve, s mintegy képzöül használva tar-tär.; 6:37. Híz, egy ellenséges s kártékony hatalmas istenség. Mint Hunfalvy Pál úrtól értém, a magyar népnél is élne még egy ilyen átkozódás »vigyen el az Iz«, mely a finn Híz-nek felelne meg.; 7:173. Mana, Alvilág, a halál birodalma, a magyar Manó.; 17:310 Csuma, Erdélyben az ártalmas kórok és járványok képzelt szellemének neve, finnül, kuuma." BARNA 1871: 324-334.
} 
elmondhatjuk, hogy az etimologizálásokkal és az előszóban rendkívül hangsúlyos finnes utalásokkal a fordító a finnugor háló megalapozásának igényével a hagyomány folytonosságának az érzékeltetésére törekedett.

\subsubsection{Korabeli viszonyulás Barna rekonstruáló törekvéseihez}

Barna Ferdinánd átültetése a teljes Új-Kalevala fordítások sorában a világon a negyedik. Azt gondolhatnók, hogy a több mint 22000 sor magyarítását (legalább) a finnugor rokonság hívei érdeklődéssel és örömmel fogadták. Hiszen ezt megelőzően csak részfordítások jelentek meg: Hunfalvy Pálé és Fábián Istváné, és bár ezek nem tartoztak a legsikerültebb átültetések közé, mégis úgy tekintettek rájuk, mint egy teljes fordítás előhírnökeire. Ennek fényében legalábbis meglepő az a - többnyire negatív viszonyulás, mely Barna Ferdinánd fordítását a megjelenéstől szinte napjainkig végigkísérte.

A megjelenés évében Magyarországon két híradás tudósított a teljes, magyarra átültetett finn eposzról. Az egyik teljes egészében elítélő: „A Kalevala a finnek hires nemzeti éposza pár nap előtt jelent meg az akademia kiadásában. Barna Ferdinánd muzeumi könyvtárőr és az akademia levelező tagja forditotta, ki lehet nagyon alapos ismerője a finn nyelvnek és irodalomnak, de forditásában nem tudta kellóleg visszaadni a hires éposz költői szépségeit. A könyvet az Athenaeum irodalmi társaság nyomdája igen díszesen állitotta ki", 135 a másik, ezt követően még jó pár évig egyedüliként, elismerő hangnemben: „A naív ősköltészet, mely közvetlenül termett ki eredeti talajából, mint paradicsom-kert, mint az ősi Flóra egész rengeteg gazdagsága az illetlen, termőerejének egész feszülő teljében eredő humusból, idegen földbe való átültetésekor teremtő erejű költőt kíván, hogy sokat ne veszítsen részegítő illatából. Mindent az idegen nem kívánhat, sőt ily nagy föladatra termett erőkkel is csak ritkán rendelkezhet. Így alig marad több hátra, mint óriási szorgalommal, a szakértelem és tárgyszeretetének lelkiismeretével, szóval azzal, a mi a hatalmunkban van, pótolni azt, a mi nem magunktól függ. Barna Ferdinánd úr, a Kalevala magyar fordítója, ez utóbbi szempontból nagy föladatának magaslatán áll. Őt a mellett áthathatta a költészet melege is s olvashatunk a Kalevalában nem egy helyet, hol a korrektség - mert Barna mindenütt korrekt - a költőiséggel karöltve jár" ${ }^{136}$ Egy dologban ellentmond egymásnak a két híradás, mégpedig Barna költői megvalósításának tekintetében. Az elsőként idézett ismertetés nem is mond ennél többet. A második a „megkívánt költőiséget” a fordításra került mú természetéből, múfaji sajátosságából vezeti le. A finn Ka-

\footnotetext{
${ }^{135}$ Figyelő 1871/20: 240. [kiemelés tőlem - V. P. I.]

${ }^{136}$ Reform 1871. július 28.
} 
levala nem más, mint naiv ősköltészet, ebből következően pedig a nyelv, amelyen/amely által megszólal, metaforikus - költői. Az utóbbi még mond valami nagyon fontosat, mégpedig azt, hogy megértette a fordító előszavát és jegyzeteit, megértette a fordítói intenciót, és meglátásában Barna sikeresen vitte véghez mindazt, amit célként kitüzött maga elé.

A magyar fordítás megjelenésének híre Finnországba is eljutott. A Kirjallinen Kuukauslehti havi lap egyik 1872-ben megjelent számában ír a magyar kiadásról, és nagyon pozitívan nyilatkozik Barna fordításáról. Külön kiemeli a fordító előszavát és jegyzeteit, a kötet díszes borítóját, melyet a finn „luxuskiadással” tart egyenrangúnak. Magáról a szövegről is jó a véleménye, úgy véli, hogy a célnyelvi olvasónak a forrásnyelvihez hasonló élményben lehet része: „A versmérték a finnhez hasonlónak mutatkozik, azzal a különbséggel, hogy a szókezdő betürímek helyett általában végrímet használ. Magyarázatokat a kötet végéhez illesztve találunk. De figyelmet részünkről leginkább a fordító előszava érdemel, ahol az ősi finn és magyar költészet hasonlóságairól ír."137

Ugyanebben az évben a fordító munkájának elismeréseként, Otto Donner ${ }^{138}$ ajánlására a FIT levelező tagjainak sorába veszi fel Barnát, majd 1884ben a Finnugor Társaság (Suomalais-Ugrilainen Seura) hívja meg külső tagjai közé. A hatástörténet legfontosabb állomása az 1897-ben megjelent Magyar Mythologia, melyben a szerző Kandra Kabos explicite is erre a fordításra támaszkodik, különösen a jegyzetekre. Úgy tűnik, hogy Barna Ferdinánd folytonosságteremtő törekvéseit a korábban említett recenzensen kívül csak Kandra értette meg. Mitológiája előszavában így nyilatkozik: „Mythologiánk alapvető szent-írásául a finn Kalevalát fogadtam el, mint amely a néphagyomány-töredékeinkkel egykorú s e mellett tisztább is, vegyưletlenebb is. Azt hiszem, hogy még egyszer mythologiát írva, Ipolyi [Arnold] sem tenne másként; avagy ha ezt tette volna, nem annyi sok kifogásolni valóra talált volna benne a kritika." ${ }^{139}$ Kandra mitológiája azonban a magyar többrendszer perifériájához tartozott, ellentétben a hivatkozott Ipolyi Arnold által 1854-ben publikált mitológiával.

\footnotetext{
${ }^{137}$ [eredeti szöveg:] „Tämä teos, kilpailee muhkeasta ulkomuodosta sen suomenkielisen painoksen kanssa, jota tavallisesti 'loistopainokseksi' nimitetään. - Värssymitta näkyy olevan sama kuin Suomen runoissa, sillä ainoalla erotuksella, että alkusoinnun sijasta usein loppusointua eli riimiä käytetty. Selityksiä on joku määrä teoksen loppuun liitetty. Mutta enintä tarkastusta meidän puolelta ansaitsee kääntäjän esipuhe, jossa esiin vedetään muutamia vertauskohtia Suomen muinaisrunojen ja Magyarien vanhimpain muinaisrunojen välillä." Kirjallinen Kuukauslehti 1872: 30-33. Idézi WEÖRES 1962: 146-147. [fordítás tőlem - V. P. I.]

${ }^{138}$ Otto Donner (1835-1909) nyelvész, a Helsinki Egyetem tanára, a Finnugor Társaság (Suomalais-Ugrilainen Seura) alapító tagja

${ }^{139}$ KANDRA 1897: XIII.
} 
Ha Barna fordítói módszereit vizsgálva megpróbáljuk a fordítást elhelyezni az eredetközösségi vagy hagyományközösségi elven alapuló irodalmi részrendszer egyikében, azt látjuk, hogy az első magyar teljes Kalevala leginkább az utóbbihoz közelít. Etimologizálásaiban vagy az előszóban a rendkívül hangsúlyos finnugor hálóra utalásokban a hagyomány folytonosságának az érzékeltetése működött. A nyugati hálóra reflektálással pedig az eredetközösségi irodalmi felfogáshoz próbált meg utat keresni: a nyugat-európai irodalmi életben elfogadott és csodált finn eposzt mintaként állította a magyar közönség elé.

\subsubsection{A fordítás rehabilitálása új szempontok bevezetésével}

A Barna-féle fordítással szembeni, Finnországban tapasztalt pozitív hozzáállás nem tartott túl sokáig. 1909-ben, az újabb, Vikár nevéhez köthető fordítás megjelenésének évében Eemil Nestor Setälä ${ }^{10}$ már nem tartja „élvezhetőnek" Barna munkáját. Két ok miatt sem: a szerinte roszszul megválasztott fordítói módszer miatt - a finn mondatszerkezetek magyarosításával - és amiatt, hogy Barna nem volt költő. ${ }^{141}$ Ugyancsak Setälä írásában bukkan fel, immár finnül is, a Barnevalás Budenz-anekdota. ${ }^{142} \mathrm{~A}$ budenzi viszonyulás azonban ellentmond ennek. Ugyan nem publikálta a fordításról szóló tanulmányát, de a később megtalált kézirat ${ }^{143}$ nem utal arra, hogy Budenz ennyire elítélő lett volna Barna átültetésével szemben. Éppen ellenkezőleg! Barna fordítását a kettős hűség - tartalmi és formai - viszonylatában is meggyőzőnek tartja, és a sikerültebb részeket a finn eredetitől „alig különbözőnek”. A fordításelméleti szempontok bevonása mellett Budenz a finnugor mitológia rekonstruálásának lehetőségével is egyetért. Kandra Kaboshoz hasonlóan a Barna Ferdinánd-i intenciót megértette, és - írásának tanúsága szerint - teljes mértékben támogatta is.

Hogy miért pont az elítélő hangnemben írt híradás nyomta rá bélyegét a Barna-fordítás fogadtatására, arra a későbbiekben többen is keresték a választ. Domokos Péter az 1990-es években megjelent Barna Ferdinándról írott monográfiájában ${ }^{144}$ több olyan kérdést is megfogalmaz, melyre dokumentálható választ nem talál: Miért csak 1871-ben jelent meg a fordí-

\footnotetext{
${ }^{140}$ Eemil Nestor Setälä (1864-1935) nyelvész, népköltészet-kutató, a Helsinki Egyetem tanára, aki kitünően tudott magyarul is.

${ }^{141}$ Idézi Setälät (Valvoja 1909: 282.) WEÖRES 1962: 147.

${ }^{142} \mathrm{Az}$ anekdota szerint Barna Ferdinánd Kalevala-fordítása nem is igazi Kalevala, hanem csupán holmi Barnevala. Az anekdota valódiságát Hajdú Péter vizsgálta, és arra a következtetésre jut, hogy az anekdota Vikár kitalációja lehet. Vö. HAJDÚ 1985. és 1994.

${ }^{143}$ A kézirat eredeti német nyelvű változata és magyar fordítása kísérő tanulmánnyal 1994ben jelent meg. Lásd HAJDÚ - RUMOHR-NORIO - TERVONEN 1994.

${ }^{144}$ DOMOKOS 1991.
} 
tás, ha az már 1867-ben készen volt? Miért nem hivatkozik Hunfalvy Pál, aki Barnának barátja volt egyetlen írásában sem a megjelent fordításra? Miért vált Budenz kelletlenné, elutasítóvá Barnával szemben? Miért nem volt a korabeli kritikai életben, a tudományos lapokban, a publicisztikában úgyszólván semmiféle visszhangja Barna munkájának? Domokossal összhangban Hajdú Péter is úgy véli, hogy a fordítás sikertelenségének és visszhangtalanságának fő oka az, hogy fordításával Barna nem tudta megnyerni Arany Jánost a finnugor ügynek. ${ }^{145}$ Ugyanakkor Hajdú arra is felhívja a figyelmet, hogy a köztudatban élő budenzi kelletlenség a neki tulajdonított anekdotára alapoz, abból vezethető le. Budenz József egyáltalán nem volt elutasító Barna fordításával szemben, amint korábban is láttuk.

Barna fordításának rehabilitációjára majd száz évet kellett várni, a fordító-utód Nagy Kálmán tanulmányáig. ${ }^{146} \mathrm{~A}$ Vikár-fordítás fogadtatásában, ha utalnak is az első teljes magyar fordításra, Budenz József szellemes, de rosszindulatú anekdotájának két fő szempontját veszik át kritikátlanul: a fordító cél- és forrásnyelvi kompetenciáját kérdőjelezik meg. Pedig ami a fordító cél- és forrásnyelvi kompetenciáját illeti, egyet kell értenünk Nagy Kálmánnal: Barna Ferdinánd szépen tud magyarul, és hozzá kell tennünk: jól tud finnül is. ${ }^{147} \mathrm{~A}$ célnyelvi szöveg összevetve a forrásnyelvivel - néhány félrefordítást leszámítva - pontos. Barnát a magyar szöveg németes

${ }^{145}$ DOMOKOS 1991. és HAJDÚ 1985.

${ }^{146}$ NAGY 1971.

${ }^{147}$ Ezt mintegy bizonyítandó Barna Ferdinándnak a FIThez írt (1871. március 1-én) finn nyelvű köszönő levelét idézem, mely igazolhatja a Barnát ért vádak igaztalan voltát - legalábbis a finnül tudók számára. A szövegnek legfeljebb a mai fül számára idegen stílus róható fel: „,Korkeasti kunnioitettava Suomalaisen Kirjallisuuden Seura! Kunniasta, jonka Suomalaisen Kirjallisuuden Seura on osoittanut minulle, kutsumalla minua Tiedustusjäseneksensä, vastaan ottakoon Kunnioitettava Kirjallisuuden Seura nyörimmiä ja hartahimmia kiitoksiani; johon minä sydämeni syvimmästä pohjasta lähtevän vakuutukseni liitän, että niinkuin minä siihen astikin aina olen ollut Suomalaisen heimolais kansan ja sen kieltä ja kansallista sivistystä suurella visaudella ja toimeliailla käsillä edistevän Suomalaisen Kirjallisuuden Seuran suuri kunnioittaja, ylistejä ja rakastelija: niin nytpä,kun sen Tiedustus-jäseneksensä tultuani tähän minulla ei ainoaan syytä, vaan Kunnioitettavaa Kirjallisuuden Seuraa vasten jo velvollisuuttakin, - sepä sangen rakas velvollisuus on; semmoisena aina tahdon pysyä ja Kirjallisuuden Seuran minua kohden todistetun suosionsa Sen mielialansa noudattamalla voimastakaan ansaita, katsoen koko elinajani rakkaaksi tehtäväksensä: sen hengellisen sillan rakentamisen, jonka perustus, ei ilman haittoja, nyt jo on onnellisesti ja järkähtämättömästi tehtynä ja jonka tarkoituksena on oltava unkarilaisen ja suomalaisen heimolais kansojen keskenellä tieteellisen kaikki-yhetisyyden (solidaritas) toimeen saattamisella Budapestin ja Helsingin kaupunkin, ja tämän kanssa itseät molemmat kansatkin toisen toiselle lähemmäksi tuoda, sen vähäisen taidon ja voiman mukaan, joka minulla on, apua antamisella edistä, ja puolustaa; että molemmat kansat sen päälle astuen saattavat toinen toisen kanssa tutustella, itseään arvossa pitää ja veli-kättä antaa, aina ollen tässäkin kohdassa totta Kalevalan kaunis lause: Yksin elo on ikävä, / Kahen, kolmen kaunoisampi. Vastaan ottakoon Korkeasti kunnioitettava Suomalaisen Kirjallisuuden Seura vakuutuksen minun syvimmästä kunnioituksesta- 
hangzása, németes szerkezetek használata miatt is bírálták. Az tény, hogy munkája során felhasználta Schiefner német Kalevala-fordítását. A 19. század második felében a közvetítő nyelv - különösen, ha az a nyelv éppen a német - használata megengedett volt. Vagyis a kor fordításról alkotott gondolkodásának tükrében ez egyáltalán nem kellett, hogy problémát jelentsen. A francia vagy angol Kalevala-fordítások alapját is a német vagy a svéd fordítások képezték.

A már korábban is idézett, Finnországban megjelent Weöres Gyula-írás is egyfajta rehabilitációnak tekinthető. Bár ő is meglehetősen ellentmondásosan kezeli Barna fordítását. ${ }^{148}$ Az 1962-es írásában Vikár Béla fordítására mint a „jobb fordításra" utal, de emellett igyekszik Barnának is elégtételt szolgáltatni azzal, hogy a két fordításból mintegy hatsornyi rész összevetésével bizonyítja, hogy Barna pontosabban fogalmaz, mint Vikár. Ezek után állapítja meg, hogy bár Barna munkája nem volt túl költói, megjelenése idején betöltötte a tőle elvárható szerepet: a Kalevala iránt érdeklődők számára anyanyelven nyújtotta a megismerkedés lehetőségét, valamint a finnekre és irodalmukra is felhívta a figyelmet.

Az 1970-es évekbeli rehabilitációja arra enged következtetni, hogy Barna munkájának újrafelfedezéséhez a fordításelméletben bekövetkezett horizontváltásra volt szükség. A cáfolatok azonban így is megkésve érkeztek. Napjainkra ugyanis, minden erénye ellenére, Barna Ferdinánd átültetésének nyelvezete elavult, valóban csak fordítástörténeti adalékká vált.

A megválaszolhatatlan kérdések sora még folytatódhatna. Az okok vagy a lehetséges válaszok közül kettőt tartok a többinél hangsúlyosabbnak, ami a részleges visszhangtalanságot vagy éppen a negatív fogadtatást magyarázhatja. Egyfelől az, hogy Barna Ferdinánd nem merte kellő határozottsággal és következetességgel felvállalni saját fordítói elveit, ami a formai megoldásokat illeti: „,fordításomat rímes versekben eszközöltnek nem kívánom tekinteni, ha még is közel jár hozzá, ez is csak azért van, mert hazai közönségünk ízlését is szem előtt kellett tartanom." ${ }^{149} \mathrm{Ez}$ a folyamatos engedménytevés az olvasók felé csak részben sikerült: a végrímes megoldások felvállalásában azonban nem volt következetes. A másik ok pedig, hogy a finnugor háló megteremtésére tett kísérlete nem talált támogatókra a magyar többrendszer központjában.

ni, jolla olen Korkeasti kunnioitettavan Suomalaisen Kirjallisuuden Seuran nöyrin palvelias Ferdinand Barna." HIRVONEN - MAKKONEN - NYBONDAS 1981: 110-111.

${ }^{148}$ Weöres egy 1958-ban megjelent, Vikárról szóló írásának bevezető részében Barna fordításával is foglalkozik. Ezekben a sorokban, mint előtte már annyiszor, Barna költői tehetségét, valamint a népköltészetben való jártasságát hiányolja. Vö. WEÖRES 1958: 266

${ }^{149}$ BARNA 1871: XIV. 


\subsection{Második kísérlet - Vikár Béla fordítása}

A következőkben lássuk a Vikár Béla fordította Kalevala fogadtatását. Előfeltevésem az, hogy az 1920-30-as évektől kezdődően a finn eposzhoz és a Kalevala-fordító Vikár Bélához való viszonyulásban a kultikus szempont dominál. Bár a kultikus szempontokat csak a Vikár személyéhez kapcsolt alfejezetben tárgyalom, a fordítás fogadtatásában felmerülő kultikus nyelvhasználatra végig utalni fogok. Különösen ami az 1935-ös, a Vikárfordítás második kiadásának fogadtatását illeti. A Régi-Kalevala jubileuma, majd az azt követő majd' tíz év a finn eposz magyar fogadtatásában a legtermékenyebb évtized. Ennek a ténynek tulajdonítható, hogy az ezzel az időszakkal foglalkozó rész a többinél terjedelmesebb.

A jubilumi Kalevala-kiadásban publikált Kosztolányi Dezső által jegyzett esszével külön foglakozom, mivel - Kosztolányi személyén keresztül - olyan támogatást biztosított a magyar többrendszer központjából és az esszén keresztül - olyan fogalmi keretet nyújtott, mely lehetővé tette a finnugor háló megteremtését.

\subsubsection{Vikár fordítói stratégiája és viszonyulása elődjéhez}

Vikár Béla teljes Kalevala-fordítása 1909-ben jelent meg először az Akadémia kiadásában. De már 1909 előtt is jelentetett meg a fordító részleteket a készülő fordításból: 1890-ben a Budapesti Szemlében, 1901-ben A Kalevalából. A Lemminkäjnen-runók és 1908-ban Kullervo énekei címmel külön kötetben.

Az 1890-ben publikált részletek elé írt bevezetőben a fordító vall az újrafordítás miértjeiről: „,kell-e a Kalevalát újra lefordítani. Meggyőződésem erre a kérdésre igennel válaszol. S így fog válaszolni a Kalevalának minden ismerője, a ki elött egyszersmind nem titok az a viszony, melyben tisztelt elódöm müve az eredetihez áll. Korántsem akarom kisebbíteni Barna Ferdinánd érdemeit. Nála nélkül talán máig sem volna magyar Kalevalánk. De kétségtelen, hogy kísérlete - még pedig önmagában rejlő okoknál fogva - meddő maradt. Magán a fordítón és ifj. Szinnyei Józsefen kívül, a ki a finn irodalommal és nyelvészettel leginkább foglalkozik nálunk, jobbára csak a finn nyelvet tanuló ifjúság kenyere a magyar Kalevala, mint - elismerem - igen használható segédkönyv. Irodalmi kelete nincsen. Aesthetikusaink figyelmét nem foglalkoztatja." ${ }^{150} \mathrm{~A}$ fordítás okainak taglalása mögött felfedezhető egyfajta kultikus viszonyulás ${ }^{151}$ az eposzhoz és az előző Kalevala-fordítóval

\footnotetext{
${ }^{150}$ VIKÁR 1890: 161. [kiemelés tőlem, V. P. I.]

${ }^{151}$ Vikár Béla önkultusz-konstruáló stratégiájáról lásd bővebben az ezzel foglalkozó alfejezetet.
} 
oppozícióba helyezett önmagához is. Az vitathatatlan, hogy Vikár (ön)tudatosabb fordító Barnánál. Az előbbiek mellett a fordítói stratégia taglalása is erre enged következtetni: „Még a tárgyi hűség dolgában van néhány megjegyeznivalóm. Előttem, mint Barna Ferdinánd előtt, szintén fődolog volt a tartalmilag hü fordítás. Erre teljes erőmből törekedtem is, de nem szolgailag. S a mennyiben fordításom egy-egy lényegesebb pontra nézve is eltér Barnáétól, bátran mondhatom, csak annyival közelebb áll az eredetihez."152 Vikár tudatában van az olvasói elvárásoknak, és ennek függvényében alakította ki fordítói koncepcióját, mely a formai megoldásokat illetően a célnyelvi befogadót tartotta szem előtt: „A helyes elv tehát csak az lehet, hogy a fordítás a maga nyelvén jó legyen, s eredeti gyanánt hasson. (...) másfelől jobban vélek megfelelhetni czélomnak azzal, hogy a fordítást rímekben eszközlöm, míg Barna Ferdinánd csak korlátozva él a rímmel. Szerintem azonban az alaki hüség kívánalma egyenesen rímes fordításra utal." ${ }^{153} \mathrm{~A}$ fordításában használt nyelvi regiszter megválasztását a forrás- és célnyelvi befogadó ekvivalenciájával motiválta: mivel a Kalevala nyelve - legalábbis Vikár szerint - a „legtisztább és legszebb finn nyelv”, ezért indokolt a különféle magyar dialektusokból meríteni az eposz fordításakor. Ugyanezzel a biztonsággal magyarázta a végrímek és a felező nyolcas sorok használatát is. A forrás- és célszöveg közti formai különbségeket pedig a közös eredetből kiindulva, a finnugor háló valamikori létezését feltételezve, a szétfejlődéssel indokolta: „valószínűnek tartom, hogy az ősi magyar - s általában a finn-ugor - elbeszélő versalak teljesen azonos volt a Kalevaláéval és belőle alakúlt nálunk olyanná, milyennek ma legrégibb költői maradványaink- s a székely balladákból ismerjük." 154

Vikárnak a Barna Ferdninándhoz füződő fentebb vázolt viszonya élete végéig nem változott. Gyakorlatilag nemcsak Magyarországon ",folytatott hadjáratot" elődje ellen, hanem finnországi felszólalásaiban is folyamatosan rontotta elődjének és munkájának hitelét. Egy 1929-ben megjelent finn nyelvü írásában ${ }^{155}$ például ő maga idézte a Budenz-anekdotát: „,az én

\footnotetext{
${ }^{152}$ VIKÁR 1890: 182. [kiemelés tőlem, V. P. I.]; Vikár ugyanitt három példával is szemlélteti,
} hogy fordítóelődje félreértette a forrásszöveget: a havukka szót (3:316) Barna nyirvesszőnek fordítja, miközben az héját vagy sólymot jelent, vagy a lumme (3:321), amit virágnak fordít, az tavirózsa, tündérrózsa és legvégül a Már a lábam folyó hordja (3:455) sor inkább Lábom már a folyó fogja. (uo. 183.) Ugyancsak kifogásokkal él a Barna által használt szenvedő igealakokat illetóen, pl. Jöttél talán megsüttetned/ Karikaszem megfózetned? (uo. 163.) Ez utóbbi főként azért érdekes, mivel - amint azt az utolsó fejezetben látni fogjuk - maga Vikár is használ ilyen típusú szenvedő igealakokat.

${ }^{153}$ Uo. $162-163$.

${ }^{154}$ Uo. 171.

${ }^{155} \mathrm{Az}$ írás a Helsinkiben, 1928-ban elhangzott Kalevala-napi ünnepi beszéd írott változata. Az ünnepségre Vikár Béla a Kalevala Társaság díszvendégeként érkezett. A hallgatóságban ott volt a Helsinki Egyetem magyar lektora Weöres Gyula és egy Dedinszky Gyula nevezetü evangélikus lelkész, aki egyéves ösztöndíjjal tartózkodott Finnországban. Őt idézem: „Feb- 
Kalevalám nem Barnevala, ahogyan játékosan Barna fordítását nevezték, hanem maga a magyar Kalevala" ${ }^{156}$ Bármennyire is anekdotázó volt a történetmesélés stílusa, ebből is, valamint az elmesélt történet ${ }^{157}$ apropóján is egy tudatos, (ön)kultusz-konstruáló stratégiának lehetünk tanúi.

Az első fordításrészletek megjelentetésekor, a hozzájuk kapcsolódó írásában Vikár a Barnáéhoz nagyon is hasonló fordítói stratégiát vázol. Felbukkan a finnugor háló megteremtésének gondolata is, mely majd csak az 1930-as években tér újra vissza. Barna Ferdinándhoz hasonlóan, ő is úgy véli, hogy Väinämöinen bűvigéi és a magyar ráolvasások „egyazon ősi néphitnek közös elemei", ebből kiindulva pedig amellett foglal állást, hogy a Kalevalának magyar „nemzeti közkinccsé” kell válnia.

Az 1909-es kiadás egy tizenegy oldalas Elóljáróban című előszóval indít és egy rövid névmagyarázatokat tartalmazó Szótárral zár.

Az előszó szerkezetét tekintve sokban különbözik Barna Ferdinánd előszavától vagy Vikár már említett, 1890-es írásától. Ha Barnánál a nyelvrokonságra, a finnugor hálóra hivatkozásnak lehetünk tanúi, Vikár erre csak az előszó végén utal. Hangsúlyosabb benne Finnország történelmi helyzetének felvázolása, a Kalevala keletkezésére, összeszerkesztésére vonatkozó adatok felsorakoztatása. Ezek után ír a finn eposz európai sikeréről és magyarországi korabeli fogadtatásáról: „A Kalevalát ebben a végső szerkezetében az előbbinél még nagyobb elismeréssel fogadták Európa szerte. Fordításai sorra jelentek meg minden művelt ország nyelvén,

ruár 28. Kalevala nap, nemzeti ünnep Finnországban. Ebben az évben azért volt különleges, mert részt vett rajta Vikár Béla, a Kalevala magyar fordítója. Előadást tartott az esti ünnepségen az egyetem dísztermében, ahol a köztársasági elnök is jelen volt. Én is ott voltam, Weöres Gyula lektor mellett ültem, és előre örültem, hogy az ünnepi szónok magyar. De végül nem voltam annyira elégedett híres honfitársammal. A jó megjelenésű, ősz hajú és szakállú Vikár Béla hatalmas munkát végzett a Kalevala lefordításával, de az előadása nem tetszett nekünk, magyaroknak. Nem beszélt a Kalevaláról, sem a fordítói munkájáról, hanem csak magáról és azokról az elismerésekről, melyeket kapott. A jelenlévő kollégái is hasonlóképpen érezhettek, mint én, mert tapintatosan azt mondták: ha a vendég előadása nem lett volna olyan élvezetes, még azt gondolhatta volna az ember, hogy önmagát dicséri. De ezt a finnek megbocsátották, főként azért, mert finnül beszélt." Dedinszky 1991: 60-61. (Csepregi Márta fordítása, az észrevételért is őt illeti köszönet.)

${ }^{156}$ [eredeti szöveg:] „Minun Kalevalani ei ole Barnevala, niin kuin tohtori Barnan käännöstä leikillisesti nimitettiin, vaan että se on unkarilainen Kalevala." [fordítás tőlem, V. P. I.] VIKÁR 1929: 222. Vikár szövegeiben a Budenz-anekdotára utalás később is felbukkan: [Budenz József reagálása Barna fordítására] „Barna Ferdinánd kedves barátom művének két hibája van. Az első az, hogy ő nem tud elég jól finnül. De ez csak a kisebbik hiba. Sokkal nagyobb az, hogy magyarul sem tud olyan jól, mint a Kalevala fordítójának tudnia kellene. Ó nem elég költó ehhez. Azért fordítása nem is igazi Kalevala, hanem csak holmi Barnevala." VIKÁR 1936: 68. [kiemelés tölem, V. P. I.]

${ }^{157} \mathrm{Az}$ anekdota a teljes fordítás megjelenésének körülményeiről szóló történetbe ágyazva hangzik el. A történet arról szól, hogy Vikár a kiadótól 80 koronát kért 16 oldalanként. A kiadó ezt túlzásnak tartotta, és arra hivatkozott, hogy Arany Jánosnak sem fizetett 40 koronánál többet az Arisztophanesz-fordításért. 
s körüle egész irodalom keletkezett. Nálunk sem maradt észrevétlenül. Kiváló tudósaink és íróink lettek rá figyelmessé. Hunfalvy Pál, az akkori nyelvészgárda feje, a Kalevalát roppant nagyra tartotta s finn olvasókönyvébe is fölvette; sőt az elnyomás szomorú napjaiban nem egyszer fordúlt a Kalevala szavaihoz vigasztalásért és reményért" ${ }^{158} \mathrm{Az}$ idézet utolsó részéből kiolvasható finn-magyar analógia ezt követően még egyszer megjelenik az előszóban, amikor a fordító a Finnországban és Magyarországon tett gyűjitóútjairól számol be. A két országban tett gyüjtőutak, valamint a gyüjtött anyaggal való „tüzetes foglalkozást” tartja a jó Kalevala-fordítás kulcsának. A korabeli magyar irodalmi köztudatban élő eposzfelfogáshoz és a Kalevala műfaji problémáihoz való viszonyuláshoz igazodva, többékevésbé egyetért a finn eposz müfaja ellen felhozott kifogásokkal, a nem epikai elemek túlzott jelenlétével. Azonban ezen túl is lép, a finn ősköltészet legeredetibb és legközvetlenebb részének tartva a „pompás lírai részleteket” és a „csodálatosnál csodálatosabb ráolvasásokat".

Ami a fordítóelődjéhez füződő kapcsolatát illeti, itt nyilatkozik legvisszafogottabban róla, amikor nem annak hibáival indokolja az újrafordítás szükségességét, hanem az újabb Kalevala-kutatások eredményeire hivatkozik: „A Kalevala nyelvünkön már 1871 óta megvan Barna Ferdinánd akadémiai tag fordításában. $\mathrm{E}$ mű azonban rég elfogyott, $\mathrm{s}$ újabb fordítással való pótlása ezért is, de többi közt a Kalevalára vonatkozó terjedelmes irodalom eredményeinek fölhasználása végett is kívánatosnak mutatkozott." 159 Sőt, forrásként is megjelöli, amit az énekek előtt levő tartalmi összefoglalókban ${ }^{160}$ Barnától felhasznált. Igaz, más kölcsönzéseit ennyire expliciten nem vállalja fel

Öntudatos szerzőre vall az a mód is, ahogyan és amikor az olvasóhoz szól: a legproblémásabb helyeken - a müfaji kérdések vázolásakor - állításként fogalmazza meg, hogy ",az olvasó egyet fog érteni velünk”, vagy a tekintélyelv alapján hivatkozik Gyulai Pálra és gróf Kuun Gézára, kinek emlékére a fordítást ajánlja, mint akik „legélénkebben” érdeklődtek a fordítás iránt vagy éppen nem tudtak „,betelni a költemény dicséretével”.

Vikár Béla tehát bármennyire is Barna Ferdinánddal szemben pozicionálta önmagát és fordítását, kettőjük célkitüzéseiben meglehetősen sok a közös pont, főleg ami a finnugor háló megteremtésének tervét illeti.

\footnotetext{
${ }^{158}$ VIKÁR 1909: X.

${ }^{159}$ Uo. XII

${ }^{160}$ A tartalmi összefoglalókat az 1935-ös kiadásban saját verseivel helyettesítette. Egyedül az 1985-ös kiadás tér vissza ezekhez a tartalmi összegzésekhez. Barna Ferdinándon és Vikár Bélán kívül egyik fordítónál sem találjuk ezeket az összefoglalásokat. Voigt Vilmos egyik írásában még Vikártól is elvitatja a közlés tényét. Állítása szerint Barna fordítása óta „nem közölték magyarul e szövegeket." Vö. VOIGT 2001: 24.
} 


\subsubsection{Felkészülés a feladatra: az etnográfus Vikár}

Vikár megjelent részfordításairól két néprajzkutató, Herrman Antal ${ }^{161}$ és Sebestyén Gyula ${ }^{162}$ ír. Mindketten Vikár múfordítói eljárásait vizsgálják. Írásaikban tetten érhető az a fajta tisztelet, mely a fordítót igyekszik felmenteni minden olyan vád alól, mely esetleg a fordítás módszereivel kapcsolatban felmerülhet. Írásaik középpontjában a fordítás nyelvezete áll. A sikeres Kalevala-fordítás kulcsának az etnográfus Vikárt tartják. Ez a kiindulópont összhangban áll a kor irodalmi gondolkodásával, hiszen a finn eposz népi vagy műeposz jellegéről folyó műfaji viták nyomán ekkor a mű népeposz jellegét tartották mérvadónak. Ebben az időszakban pedig a fordításról való gondolkodásban a cél- és forrásnyelvi szöveg közti ekvivalencia, a fordítás sikere a célnyelvi kultúrához idomításon, a célnyelvi kultúra befogadókészségén állt vagy bukott. Természetesnek tűnik tehát Sebestyén megállapítása, melyben a fordítónak a forrás- és célnyelvi szöveg közti ekvivalenciára törekvését emeli ki: „hogy a finn naiv éposz népies jellegét csakis megfelelő magyar népies vonásokkal lehet híven tolmácsolni". ${ }^{163}$ Ugyanez a véleménye Herrmannak is, aki a magyar népnyelv alkalmazásával véli elérhetőnek a finn eposz és magyar fordításának ekvivalens hatásmechanizmusát. Szerinte is Vikár fordítása az, amely „a leghívebben visszatükrözi az eredetinek minden nyelvi és költői sajátságát és előidézi annak minden hatását. Mégpedig teljesen genuin, tősgyökeres, tőrőlmetszett, erős, zamatos magyar népnyelven. És halljuk az igazi, tiszta, magyar ritmus lüktetését, zenéjét."164 Vikár nyelvezete, Herrman szerint, a korabeli magyar népköltés nyelvének ideálja, és emellett olyan münek tartotta, mely magyar nemzeti müköltésként is megállja a helyét. Az etnográfus mellett a költő Vikár képe bontakozik ki ebből a tanulmányból és Sebestyén ismertetéséből is. A magyar szöveg költőiségét a formai hűséggel

\footnotetext{
${ }^{161}$ Herrman Antal tanulmánya azért is figyelemre méltó, mert a Kalevala-fordítások fogadtatásához kapcsolódó tanulmányok között még csak a Gáspár Sándoré (1977!) vázol fel fordítástörténeti hátteret. Herrman a jó fordítással szemben többnyire a Radó Antal által is leírt követelményeket támasztja. A fordításnak be kell illeszkednie a célnyelvi hagyományba, és formailag ekvivalensnek kell lennie a fordított művel: „Először úgy kell hatnia, mintha eredeti volna. Azaz mintha azon a nyelven termett volna, a melyre fordították. Másodszor úgy kell hatnia, mint a hogy hat az eredeti az illető anyanyelvi olvasóra, jobban mondva hallgatóra (...) S harmadszor lehetőleg ugyanazon eszközökkel, faktorokkal kell hatnia, mint az eredeti hat; mert általán csak kölcsönösen azonos componensekből eredhet identikus resultans". HERRMAN 1905: 244.

${ }^{162}$ Sebestyén Gyula (1864-1946) folklorista, irodalomtörténész. Elméleti munkásságának középpontjában a magyar őstörténet ált. Ennek kapcsán jutott el az összehasonlító (ural-altáji) vizsgálatok szükségességének felismeréséhez. 1913-as északi tanulmányútja során személyes kapcsolatot épített ki Kaarle Krohnnal és Antti Aarnéval is.

163 SEBESTYÉN 1901: 381-383.

${ }^{164}$ HERRMAN 1905: 246.
} 
hozzák összefüggésbe. A költőiség Sebestyén meglátásában egyet jelent a sorvégi rímekből fakadó dallamossággal, melyek ugyanakkor a finn eposzban előforduló alliterációk hiányát hivatottak kompenzálni és a trochaikus sorok egyhangúságát teszik elevenebbé. A fordító formai megoldásaival kapcsolatban Herrman óvatosabban fogalmaz: nem ért egyet a vikári magyarázattal, hogy a sorvégi rímekre és a ritmus megváltoztatására miért is van szükség, de azt ő is elismeri, hogy éppen ezek a formai megoldás tették igazán költőivé az átültetést: „,a gyakorlatban, az alkotásban teljesen bevált a fordító ritmus-érzéke". ${ }^{165}$

A teljes fordítás 1909-es megjelenése utáni írásokból Bán Aladárét emelem ki, mivel - ő maga is fordító lévén - jól ismerte a finn népköltészetet. 1910-es írására a Barna-Vikár szembeállítás jellemző. Barna az, aki „,nem tudta visszaadni a finn vers szépségeit: sem gondolat-rhytmusát, sem alliterátióit, sem a vers rhytmusát" ${ }^{166}$ Erthetetlen, hogy Barna fordítására vonatkozó bírálatát nem támasztja alá idézetekkel, ugyanakkor az legalább dicséretes, hogy a Barna-recepció túlzásait nem veszi át elődeitől és kortársaitól. Vikár fordítását a fentebb idézett Barna-bírálatból kiindulva vizsgálja, és arra a következtetésre jut, hogy az új fordítás alliterációk tekintetében „bámulatos gazdagságot mutat” és a ritmust is "híven követi" ${ }^{167}$ A formai megoldások vizsgálata után, kora fordítással kapcsolatos elveit követve jelenti ki, hogy „a fordítás hüsége ellen sem tehetünk kifogást. A mennyire csak lehet, szó szerint adja vissza az eredetit." ${ }^{168} \mathrm{~A}$ folytatásban - „de természetesen neki is élnie kell a múfordítót megillető költői szabadságokkal"169 - ugyanakkor az alkotó fordító képe jelenik meg, mintegy mentségként az esetleg előforduló pontatlanságokra nézve.

\subsubsection{Finnugor háló teremtése - kis segítséggel}

Az 1935-1945 közötti időszakban az előző évekhez, évtizedekhez képest, a Kalevala mellett jelentősen megnőtt a finn irodalmi művek kiadása is. A kiadók közül élen jár a Franklin Társulat és az Athenaeum, de olyan kiadókat is találunk, mint a Magyar Élet vagy a Turul. Az okok között Szopori Nagy szerint egyaránt szerepel az 1937-es államközi egyezmény, a Kalevala-jubileum, a háború alatti szövetség, valamint a sorsközösségérzet, mely a két ország hasonló politikai helyzetéből fakadt.

\footnotetext{
${ }^{165}$ Uo. 247.

${ }^{166}$ BÁN 1910: 124.

${ }^{167}$ Uo.

${ }^{168}$ Uo. 125.

${ }^{169}$ Uo.
} 
Szopori Nagy Lajos a finn irodalom magyarországi fogadtatásáról írott könyvében az áttörés éveként az 1935-ös évet nevezi meg. Ekkor ugyanis nemcsak Magyarországon, hanem egész Európában a Régi-Kalevala megjelenésének százéves jubileumát ünnepelték. Ez az az év, amikor a Kalevala iránti, 1920-as évekbeli lanyhuló érdeklődés ismét felélénkül. Vikár Kalevala-fordítását a La Fontaine Társaság - melynek Vikár Béla alapító tagja majd titkára is volt - 1935-ben és 1940-ben is kiadta: egy díszesebb változatban és egy olcsóbb, háromkötetesben.

Pár évvel később, 1943-ban és 1944-ben pedig újra megjelenhetett a teljes szöveg a Magyar Élet kiadó gondozásában.

\subsubsection{A Kalevala 1935-ös, jubileumi magyar kiadása}

A díszkiadás két kötetben jelent meg, a fordításszöveg mellé csatolták a Magyarázatok a Kalevalához címü kötetet is. A fordítást tartalmazó kötet piros-fekete-fehér színü. Egyszerre magyaros és finnes: színeiben magyaros, motívumában finnes - összekapcsolódó ujjak, mely a runóéneklésre készülőket szimbolizálja és a finn Kalevala Társaság jelvényében is megtalálható. A kötet Akseli Gallén-Kallela készítette illusztrációit jogdíffizetés kötelezettsége nélkül a művész fia, Jorma bocsátotta a magyar kiadó rendelkezésére, a papír pedig a finn állam ajándéka volt.

Az 1935-ös szöveg különbözik az 1909-es kiadásétól. A szövegváltozat módosításait maga a fordító végezte.

A jubileumi kiadás tehát egyszerre próbál meg finnes és magyaros is lenni, miközben maga a szöveg, a Vikár-féle magyar asszociációkkal teli summázó versikéken keresztül a finn nevek kiejtés szerinti írásáig inkább magyaros, honosító, az idegenségérzetet megszüntetni akaró változat. Az utolsó fejezetben vizsgálandó tartalmi különbségek arra utalnak, hogy a fordító igencsak szem előtt tartotta olvasóközönsége elvárásait. A tabutémák megjelenítésének fokozatossága is ezt sugallja. ${ }^{170}$

A Magyarázatok a Kalevalához kötet borítóján Vikár Béla neve szerepel. Ő írta ugyanis a kötet magyarázatok részét: a Kalevala-hősök, a finn nevek magyarázatát és a magyar szövegben megjelenő tájnyelvi szavak meghatározásait. Emellett a kötetben megtalálható Kosztolányi Dezső Kalevalaesszéje, Balassa Imre utószava és Zempléni Árpádnak a fordítóhoz írt egyik levele.

${ }^{170}$ Lásd az utolsó fejezetet. 


\subsubsection{Kosztolányi Dezső Kalevala-esszéje}

Kosztolányi Dezső, aki maga is a La Fontaine Társaság tagja és 1933-tól társelnöke is volt, Vikár Béla felkérésére írta meg Kalevala-esszéjét, mely először a Pesti Hírlapban jelent meg ugyanazon évben, folytatásokban.

$\mathrm{Az}$ alábbiakban témakörök szerint csoportosítva vizsgálom meg az esszét.

\section{Lönnrotés a Kalevala}

A Lönnrotot bemutató sorokban az eposzszerkesztő mesebeli vándorként tünik fel, aki szegényen, veszedelmekkel dacolva, de kitartással halad kijelölt célja felé: „Ez a szegény kerületi orvos - egy szabó fia - hátán batyu, kezében vándorbot, gyakran mezitláb rótta az elhagyott tájakat, a sötét erdőket, a veszedelmes zsombékokat, hogy megközelítsen egy kunyhót s összeismerkedjék lakóival. (...) A szellemi kincsek nemcsak könyvtárakban vannak polcokra fölsorakoztatva. Benn a lélekben is akadnak szellemi kincsek, nem láthatók és meg nem foghatók. Ezeket kereste a vándor. Igazi öröme abban telt, ha sikerült meglesnie két aggastyánt, amint ősi szokás szerint egymással szemben ülnek egy lócára s kezüket fogva, fejüket, törzsüket ingatva hosszú, elnyújtott kántálással adják elő azokat az istenekről, szellemekről szóló csodálatosan-rozsdás verseket..."171 Ugyanezzel az elfogultsággal beszél a finn eposzról is: a Mahabharata, az Iliász és a Nibelung-ének mellé helyezi, hatalmas alkotásként aposztrofálja, olyan műként, mely valósággal megrázta a világot úgy, "mintha a pogány istenek személyesen jelentek volna meg". ${ }^{172}$

Kosztolányi úgy hangsúlyozza a finn eposz egyediségét és másságát, hogy közben a Kalevala hőseit a görög és római mitológia hőseivel hasonlítja össze: Väinämöinen „, a finn Apollo vagy Orpheus”, Ilmarinen „,afféle Herkules vagy Hephaistos" vagy Tuonela ", finn Styxen”. Ezzel tulajdonképpen egy olyan eposzi sorba emeli a Kalevalát, amelybe addig a magyar irodalmi rendszer központja nem volt hajlandó behelyezni. Gondoljunk csak Szász Károlynak a világirodalom eposzairól szóló művére, ahol a Kalevala a Kalevipoeggel együtt a toldalékban szerepel. ${ }^{173}$

De rögtön kitér azokra a sajátosságokra is, melyek a finn eposzt a görög és római eposzoktól megkülönböztetik: „Nem hősköltemény abban az értelemben, mint az indusok, görögök vagy latinok értették ezt. Talán inkább így nevezhetnők: ősköltemény. Nem lehetne azokkal a szavakkal kezdeni,

\footnotetext{
${ }^{171}$ KOSZTOLÁNYI 1935: 3.

${ }_{172}^{170 .} 4$.

${ }^{173}$ Vö. SZÁSZ 1929.
} 
mint az Aeneist: Arma virumque cano. A fegyverek itt nem katonai célokra valók, idegen népek leigázására, hanem többre és nagyobbra, a természet meghódítására. (...) Szerkezete sem olyan, mint Homeros vagy Vergilius hőskölteményeié. Ágbogas, összeszőtt-font mellékcselekmények, lírai betoldások gazdag halmaza ez, tele gyermeteg ellentmondással, lángeszü szeszéllyel, egymásra hányt kincsek tékozló, keleti bősége."174

A különbségek mellett talál magyar-finn párhuzamokat is. Így lesz például a kereszténység felvétele után Kaleva földjéről távozó Väinämöinenből „dalos Koppány".

Az analógiák sora tovább folytatódik, Kosztolányi nyelvi bizonyítékokat is talál: „A halottak névtelenül és titokzatosan aludtak kissé lecsökkent élettel (...) a birodalomban, melyet a finn hitrege tárgyiasan Manala-nak nevez, mely - mint a szó rokon idoma is mutatja - nem jelent egyebet, mint Föld alatt, vagy Tuonelá-nak, mely nyelvünkön is csak ennyi: túlnan."175

\section{A magyar fordítás és fordítója}

A magyar-finn párhuzamok a magyar fordítás és fordítója, valamint a finn eposz és összeszerkesztője egymás mellé állításával is működtethetővé válnak. Vikár Béla Lönnrothoz hasonlóan mesebeli alakként jelenik meg a szövegben. A fordító a finn eposz magyarra ültetésének sikeréért önként vállalta a vándoréletet, a vidéki életet: „Ő [Vikár Béla] teljes két évtizedig búvárkodott és dolgozott, belehatolt a Kalevalába, ebbe a mérhetetlenül gazdag őserdőbe, finn földön is élt, vidéken e nép közt, aztán az elkészült verseket itthon fölolvasta kenesei parasztoknak, betanultatta velük $s$ az önkéntelen változtatásokat, melyeket az ütemeken és a szavakon tettek, értő kézzel belemunkálta a szövegébe ${ }^{1176}$ A néptől való tanulás az etnográfus Vikárhoz, ezen túl pedig a Kalevala népi eredetéhez visz közelebb. Kosztolányi tulajdonképpen azt a felfogást erősíti meg, amely az 1909 utáni korszakot is meghatározta: csak így, kitűnő néprajzosként és a Lönnrotéhoz hasonló elhatározással és lelkülettel lehet a finn eposzt magyarra ültetni. ${ }^{177}$

Kosztolányi, akárcsak Sebestyén Gyula vagy Herrman Antal, felmenti Vikárt minden olyan vád alól, mely fordításának nyelvezetére vonatkozik. Az öt évvel korábban, 1930-ban megjelent Zolnai Gyula-tanulmány ${ }^{178}$

\footnotetext{
174 KOSZTOLÁNYI 1935: 6.

${ }^{175}$ Uo. 7. [kiemelés az eredetiben] E dolgozat szempontjából lényegtelen, hogy az etimologizálások - Manala $=$ maan alla $=$ a föld alatt - megállják-e vagy sem a helyüket.

${ }^{176}$ Uo. 5.

${ }^{177}$ A Lönnrot-Vikár-párhuzam többször is felbukkan a későbbiekben is. Pl. Vikár Somogyban és Erdélyben gyalog járva gyüjtött, akárcsak Lönnrot. Vö. VOLLY 1959.

${ }^{178}$ ZOLNAI 1930: 118-125.
} 
kimondottan a Vikár-fordítás nyelvének vizsgálatát és elemzését tűzte ki célul. Lényegében Zolnai az első, aki a fordító által használt nyelvváltozatot bírálva magát az etnográfus Vikárt bírálta a túlzott népnyelvi és tájszavak használata miatt. Úgy vélte, hogy ezek ismertek lehetnek ugyan egy képzett néprajzos számára, azonban az olvasó előtt ismeretlenek. Véleményét példákkal is alátámasztotta, és felhívta a figyelmet arra, hogy mindezeket elkerülhette volna a fordító, hiszen poétikai szempontból sem lett volna problémás a köznyelvi(bb) szavak használata. Zolnai a fordításban előforduló újszerű szavakat is kifogásolta, mivel azok idegenek a müfajtól, nem illenek egy őseposzba. Ezzel szemben Kosztolányi szerint a fordító: „megtartotta a mai pallérozott szó- és szólamkincset, de inkább ízelitőül, sohasem az érthetőség rovására, hanem jellemzésül és színfoltul tájszavakkal tarkázta a szöveget, az ország minden részéből, háromszéki és göcseji szavakkal éppúgy, mint felsőtiszai és csallóközi szavakkal, ezenkívül fölelevenítette néhány kihalt és régi szavunkat kódexeinkből s merész, talpraesett ötlettel - elvonások útján - új szókat is formált." ${ }^{179}$ „Mesterien-mesterkélt” és „nemlétező” nyelvnek láttatja a Vikár által használt nyelvet, mely éppen egyszeri volta miatt felel meg tökéletesen egy olyan alkotásnak, mint a Kalevala: „mesterien-mesterkélt, mégis természetesen folyó varázsos nyelvvel pedig elérte, hogy a Kalevala mintegy gyüjtőmedencéje, olvasztótégelye lett egész szókincsünknek. (...) Nemlétező nyelv ez, de izig-vérig magyar..."180

Azzal, hogy Arany János Hamlet- és Bérczy Károly Anyegin-fordítása mellé helyezi a Vikár-féle Kalevalát, a kanonizáció útján indítja el a művet. Az egymás mellé állításban Arany neve és a már a kanonizálódott Bérczy-fordítás hatása válik működtethetővé. Ugyanezzel a szándékkal kerülhetett bele Kosztolányi szövegébe a később is sokat idézett Paasonenkijelentés: ${ }^{181}$ "A finnek ma is állítják, hogy Vikár Béla fordítása mindegyik között a legkülönb. Paasonen Henrik szerint belőle vissza lehetne állítani a finn szöveget, ha történetesen elvesznék."182

\section{A Kalevala mint magyar ôseposz}

Kosztolányinak a fordítás nyelvezetéről vallott felfogásában már benne foglaltatik a Kalevala mint magyar óseposz gondolat csírája. A nemlétező nyelv nem csupán konstruált, hanem egyben rekonstruált is: „homályos

\footnotetext{
${ }^{179}$ KOSZTOLÁNYI 1935: 5.

${ }^{180}$ Uo.

${ }^{181}$ A Paasonen-kijelentést Finnországban is többen idézik. Egyik, még 1928-ban elhangzott beszédében a festő, Akseli Gallén-Kallela (vö. 1929: 210.), vagy A. O. Väisänen A Vikár Béláról szóló megemlékező írásában (vö. 1945: 280.).

${ }^{182}$ KOSZTOLÁNYI 1935: 6.
} 
ősiségét érezteti nyelvünk ismeretlen multjának, azt a káprázatot keltve, hogy csak így költhették volna a mi Kalevalánkat, ha az el nem pusztul valahol Ázsia fönnsíkjain."183 A magyar királyi koronázást idéző mondat egyfajta szertartásra utal, a Kalevala magyarrá „koronázására”, emellett pedig végképp meggyőzheti a kételkedőket vagy a Vikár-nyelvezetet bírálókat a nyelvjárási szavak használatának helyességéről: „mintha ötvenkét régi vármegyénk mindegyikéből egy marok földet vett volna, hogy belőle jelképes halmot emeljen". A magyarrá tevés a rekonstrukción alapul, annak a visszaadásán „amit a kereszténység tűzzel-vassal kiirtott, ázsiai hagyományainkat, hitregéinket, a regősénekek és a virágénekek egész lelkiségét."184

Az analógiák sora még nem ér azonban véget. Kosztolányi a magyar népi hiedelmekből idéz fel párat annak bizonyítására, hogy a célrendszerben is fellelhetőek a sámánizmus, a finnugor ősi hit maradványai. ${ }^{185}$ Ezek után jut arra a következtetésre, hogy a valamikor létezett finnugor háló olyan közös tudást múködtet, mely biztosítja a hagyomány folytonosságát, és ebből kifolyólag az immár magyarrá vált Kalevala „titka még most is itt lüktet bennünk. Ezer esztendő csekély idő ahhoz, hogy a vérben lakozó ösztönöket végkép eltüntesse".

Amint arra a finn-magyar kapcsolatok felvázolásában is rámutattam, az 1930-as évekre oly jellemző módon a nyelv és néprokonság együttesen jelenik meg. Kosztolányi nemcsak az esszé végén hangsúlyozza a vér szerinti kapcsolatot, hanem az esszé elején is. A Kosztolányi-szöveg első alcíme: (A monda évezredes vándorútján. - Francia vélemény a finn-magyar atyafiságról). Már itt felülvizsgálja a 19. század sokszor ellentmondásos

\footnotetext{
${ }^{183}$ Uo. 5.

${ }^{184}$ Uo. 4.
}

185 „Parasztjaink, minekelőtte innának, az ország nem egy vidékén még ma is a földre locscsantják az ital első kortyait, hogy ezzel öntudatlanul is áldozatot mutassanak be a föld szellemének. Orvosaink hiába küzdenek a babonák, a szemverésben és rontásban való mélyen gyökerező hit ellen. Legtöbb szitkunk és káromkodásunk átkozódásból áll, mely a betegséget másra akarja áthárítani. A halott csecsemő koporsójába anyatejjel sütött kalácsot tesznek, hogy a kisded vissza ne jöjöön, mint hazajáró lélek. Körmét, haját a nép fogyó holdnál nyirja, hogy nőjjön, a jégeső közeledtére fejszét vág a földbe, hogy a rontó szellemeket elijessze s az öregasszonyok faluhelyeken, tanyákon még ma is tudnak olyan ráolvasó versikéket, melyekben föllelhetjük a pogány elemeket. Sok helyütt sellőnek, vízitündérnek hívják a folyó örvényeit. Azok a regősök Szent István szolgái, akik karácsonykor beköszöntenek a pitvarokba, még mindig nyírfakéreg-ruhájukról és nyírfabocskorukról énekelnek. Egy helyütt sámándobjukat is meglelték. Nem is régen törvényszéki jegyzőkönyvben olvastunk táltosokról és gyermekkorunkban sokat hallottunk a garabonciás diákról, aki a viharban bő köpenyegben a felhők fölött lovagol és hajtja maga előtt a szelet. Büvös számunk a 3, a 7 és a 9, akár a finneké." Uo. 12-13. 
viszonyulását a nyelvrokonsághoz, majd leszögezi, hogy „nyelvben, vérben, lélekben egytestvér velünk Suomi népe". ${ }^{186}$

A vikári célkitüzést, hogy a Kalevalával pótolja a hiányzó magyar eposzt, Kosztolányi is támogatja, amikor a finn eposz magyarországi intézményessé tételének fontosságára szólítja fel a magyar többrendszer központját: „népkönyvvé kellene tennünk, szellemiségünk és irodalmi műveltségünk gerincévé, az iskolákban kellene olvastatnunk és fejből tanultatnunk verseit." 187

\subsubsection{Balassa Imre utószava}

Balassa, a La Fontaine Társaság alelnökeként ismerhette, és már a kötet nyomdába kerülése előtt olvashatta is Kosztolányi esszéjét. Az Utószó - bár az esszénél rövidebb - szerkezetét és gondolatmenetét tekintve a Kosztolányi-szöveghez hasonlóan építkezik. Balassa is Lönnrotnak, az eposzszerkesztőnek a bemutatásával indít, aki egy „zimankós februári napon” a Kalevala-kéziratot a Finn Irodalmi Társaság asztalára tette, miután „földhözragadt szegény orvosként" minden akadállyal dacolva összegyüjtötte a kihalófélben levő népi - epikus és lírai - énekeket. Ezt követi a fordító Vikár bemutatása, aki Lönnrothoz hasonlóan „,batyuval a hátán, puskával (sic!) a vállán vágott neki az ismeretlen tájaknak, amelyeken át még gyalogút sem vezetett". ${ }^{188}$ A Lönnrot-Vikár-analógia éppen azt sugallja, hogy a magyar fordítónak is hasonló nehézségekkel kellett megküzdenie a mű létrehozása érdekében, mint annak idején a finn Lönnrotnak.

Ugyancsak elmaradhatatlan az utószóból a népköltészet által igazolt közös eredet. A magyar és finn népköltészet formai hasonlóságát és Vikár fordítói zsenialitását egy történet beiktatásával igazolja Balassa: „Mikor harminc évvel ezelőtt Vikár Béla Erdélyt járta, egy falusi kocsma udvarán székely regősöket danoltatott, hogy följegyezze a szót és a dallamot. Azután hálából - és talán kísérletképpen - elmondott nekik egy részletet a Kalevalából. És akkor egy székely dalos így szólt hozzá:

- Instálom, nincs szöbb ennél a mü székel költésünknél...

A székely nótás ember magyar dalnak hallotta a Lemminkejnen-rúnókat..."189

\footnotetext{
${ }^{186}$ Uo. 4.

${ }^{187}$ Uo. 13.

${ }^{188}$ BALASSA 1935: 114.

${ }^{189}$ Uo. 115
} 
Balassának a fordítás nyelvezetéről írott soraiban ugyancsak Kosztolányi kifejezései visszhangzanak: „A finn ősvilág szólal meg e betűkben, de a magyarság ősi nyelvén. Ez a nyelv a nép és a népköltés ős-zamatú, igazi, mesterkéletlen és mégis müvészi nyelve." ${ }^{190}$

Meglepő módon a Paasonen-kijelentés, miszerint a Vikár-fordításból visszállítható lenne a finn eredeti, csupán rejtetten fordul elő, amikor „a világirodalom legszebb és leghívebb Kalevala-fordításának" nevezi a második magyar fordítást.

Az utószó zárómondataiban Balassa arról tudósítja olvasóit, hogy a magyar kormány minden közkönyvtárnak jutatott az 1935-ös magyar Kalevala-kiadásból. Ebben a gesztusban, szerinte, egyszerre ott van a politikai akarat és a vérségi kötelék bizonyítéka. Ezzel összecseng a Kosztolányi-esszében megjelenő népkönyvvé tevés gondolat.

Utószavát Balassa egy magyar-finn analógiával zárja. A Kalevala nem más, mint „,szellemi világunk, népi lelkünk, ősi mitoszunk testvérvoltának tanuja és jelképe."191

A Magyarázatok a Kalevalához kötet tanúsága szerint Vikár Béla fordítása kettős célt szolgál: fenntartja, újra felfedezteti az elveszett (elveszettnek hitt) hagyományt és erősíti a (vér)rokonsági kapcsolatokat.

Kosztolányi a finn eposz elemzésében abból indult ki, hogy a Kalevala az egész finnugorság őseposza, és az egykori közös életmódból, a rokon nyelviségből fakadóan az eposz a maga teljes természetességében szólalhat meg magyarul. Vikár etnográfusi képzettsége pedig a finnugor ősiségre asszociáló és a magyar nyelvjárások olvasztótégelyeként aposztrofált nyelv megteremtésében segítette a fordítót. Az esszé egyedítő törekvései pedig megteremtették a finnugor hálóhoz szükséges fogalmi keretet.

\subsubsection{A müködő finnugor háló}

A Vikár-fordításról szóló ismertetések - gyakorlatilag az 1970-es évekig, a Nagy Kálmán-fordítás megjelenéséig - fenntartások nélkül vették át Kosztolányi esszéjéből a Kalevaláról és magyar fordításáról való elragadtatott beszédmódot, valamint a fordítás nyelvére és a finnugor őseposzra vonatkozó kijelentéseket. A következőkben a már elemzett kötet és Kosztolányi-szöveg hatását vizsgálom a Vikár-fordította Kalevala magyar fogadtatásában.

\footnotetext{
${ }^{190}$ Uo. 115.

${ }^{191}$ Uo. 116.
} 


\subsubsection{A fordítás nyelvezete}

A magyar Kalevala nyelvezetére vonatkozó Kosztolányi-szövegrész a legtöbbet idézett passzusok közé tartozik. Kosztolányi felfogása a Vikárfordítás nyelvérôl csak részleteiben lehetne cáfolható, a maga összességében nem. Az ízig-vérig magyar, de nemlétező nyelv képzete még a részletekbe menő Zolnai-bírálatot is felülírja. E fogalom bevezetésével ugyanis teljesen a fordító hatáskörébe utalta a fordítás szövegének bírálhatóságát. Nemlétező nyelvre csakis Vikár egyéni szabályai lehetnek vonatkoztathatóak, a magyar köznyelv (normatív) szabályai nem.

Korompay Bertalan egyik finn nyelvü tanulmányában idézi a költőt. ${ }^{192}$ Gombos László is, aki az 1940-es Kalevala-kiadást rendezte sajtó alá, teljes egészében átveszi Kosztolányi nyelvről vallott felfogását. Bár megfordítja az ok-okozati összefüggést: „maga termtett (sic!) sajátos magyar nyelvet, melyhez hasonlóan soha sehol senki nem beszélte ezt a nyelvet, de amely szintézise a magyar nyelv egész történetének és összegezése a magyar nyelv valamennyi tájszólásának. Ez a nyelv a magyar nyelv költői eredője. Nyelv, amelyen sokat lehetne elmondani. Vikár itt egy új világot tárt fel, szellemben és formában egyaránt", ${ }^{193}$ mintha Vikár Béla szándékosan és öncélúan egy sajátos magyar nyelv megteremtését tűzte volna célul maga elé. Kosztolányinál a sajátos nyelvezet csupán eszköze a mű megteremtésének.

Ugyancsak a vikári nyelvhez kapcsolódóan írja Csekey István: ${ }^{194}$ „Vikár a Kalevalába beleköltötte nyelvünknek egész bủbáját. Ebben a varázslatos nyelvben benne van a magyar költészet egész szókincse." ${ }^{195}$ Kosztolányi szövegének hatása nyilvánvaló.

Ami a finnugor őseposzt illeti, Bán Aladár az egyedüli, aki 1935-ös recenziójában a finnugor őseposz-Kalevala azonosításának gondolatát támadja. Azonban Kosztolányinak ezt a "tévedését” Comparetti számlájára írja.

A Biblia, a már idézett Gombos László egyik korábbi írásában, Kandra Kabos mitológiájához hasonlóan, összehasonlítás alapját képezi: „Nyiltan kimondhatjuk, hogy mint ahogy van finn-ugor nyelvészet, így kell lenni finn-ugor folklornak is és ennek a tudománynak a Bibliája maga a

\footnotetext{
${ }^{192}$ Lásd KOROMPAY 1956: 328.

${ }^{193}$ GOMBOS 1946: 5-8.

${ }^{194}$ Csekey István jogász, tudománytörténész. A kecskeméti jogakadémia tanáraként kap meghívást a húszas években a tartui egyetemre. Részt vesz a tartui Magyar Intézet munkájának irányításában, valamint az egyetem finnugor tanszékén meghirdetett magyar nyelvi és irodalmi kurzusok megtartásában is. Rendszeresen publikál a finnugrisztika tárgyköréből.

${ }^{195}$ CSEKEY 1936: 19.
} 
Kalevala."196 A Biblia alapkönyv, az isteni kijelentés összefoglalása. Minden, amit Isten közölni akart, megtalálható benne. Aki a Bibliát írta vagy fordította, annak kezét maga Isten vezette. Ha a Kalevala a finnugorság Bibliája, akkor a fordítás által Vikár Béla prófétává vagy apostollá, az isteni kijelentés hordozójává, közvetítőjévé válik. Nyelvezetével kapcsolatban pedig nem a keresztény valláshoz kötődő istenfiú vagy hasonló fogalmakkal operáló nyelvhasználatot találjuk, hanem - a finnugor hálóval összhangban - az ősiséghez kötődő igric, sámán fogalmakat: „Vikár azonban jóval több, mint nyelvész. Ő költő, még pedig a javából. Az ősi kobzosok, regősök, igricek, sőt folklorisztikai tudásánál fogva a sámánok utódja."197 A kobzos és igric mint történetmesélő a nyelv birtokosa, a saját, egyéni szabályokkal múködő nyelvé, mely a transzcendenssel való kapcsolatteremtést szolgálja. Mindez egyetlen személyben ötvöződik: a Vikár Béláéban.

\subsubsection{A Paasonen-kijelentés}

A Paasonen-kijelentés átvételekor az évek során fokozatosan lényegtelenné válik annak forrása. A feltétel nélküli hit az, ami megnyilvánul ezekben a kölcsönzésekben. A hit, mely egyszerre szól a Kalevalának, Vikár Bélának és nem utolsósorban Kosztolányinak. 1959-ben még egyes írásokban felmerül Paasonen neve: „Paasonen Henrik finn egyetemi tanár azt mondotta egyszer, hogy ha elveszne az eredeti Kalevala, Vikáréból vissza lehetne fordítani finnre, annyira tökéletes munka." ${ }^{198}$ Ugyanebből az évből azonban már találunk olyan írást is, ahol semmiféle utalás nincs Paasonenre vagy Kosztolányira: „Leghübb és legművészibb fordítását adta a münek, oly tökéletes formában, ha az eredeti elvesznék, az övéből lehetne az eredetit rekonstruálni." 199 A 150 éves Kalevala-évforduló felé közeledve még inkább háttérbe szorul a kijelentés Paasonent érintő része, 1970-ben pedig már csak egy finn tudós jelenik meg: „Olyan remekül sikerült ez a fordítás, hogy egyik finn tudós szerint, ha az eredeti finn Kalevala elveszne, Vikár Béla múfordításából rekonstruálni lehetne az egész művet"200, 1985re pedig teljesen általánosítva a finnek véleményeként: „A fordítás olyan kitűnően sikerül, hogy a finnek ma is azt állítják: ha az eredeti finn szöveg elveszne, a magyarból tökéletesen visszaállíthatnák." ${ }^{201}$ A finnek ma is azt állítják tagmondatban már nem csupán egy személy megnyilatkozását találjuk, hanem egy egész nemzetét. E kijelentés nem más, mint a forrás- és

\footnotetext{
${ }^{196}$ GOMBOS 1942: 788.

${ }^{197}$ CSEKEY 1936: 19.

${ }^{198}$ VOLLY 1959. [kiemelés tőlem, V. P. I.]

${ }^{199}$ HORVÁTH 1959: 77-82.

${ }^{200}$ MOLNÁR 1970: 372-374. [kiemelés tőlem, V. P.I.]

${ }^{201}$ SIPOS 1984: 120-122. [kiemelés tőlem, V. P. I.]
} 
célnyelvi szöveg teljes ekvivalenciájának az elismerése. Vagyis a két nemzetnek van egy közös tulajdona: a Kalevala. Egyaránt jelképezi a nyelv- és vérrokonságot. Ezzel pedig túlmutat a finn eposz kizárólag irodalmi múként vizsgálható voltán. Egyszerre irodalom és a finnugor identitás szimbóluma.

\subsubsection{A finnugor háló politikussá válása}

\subsubsection{A Kalevala mint a népek ifjúságának eposza}

Gulyás Pál két szövegét vizsgálom meg a következőkben: 1937-es tanulmányát és az 1943-as Kalevala-kiadás utószavát, mely a finn és a magyar történelmi analógiára utalással vezeti be a finn eposz magyar fogadtatástörténetébe a politikum szempontját.

A két szöveg között többnyire szerkezeti különbségek vannak, tartalmi különbségek alig találhatóak. A tanulmányban rendkívül erőteljes a nyugati hálóra hivatkozás: Gulyás meglátásában a homéroszi eposzokkal és Dante Isteni színjátékával egyaránt rokon a finn eposz. Amiben mégis más, az éppen a nyugati hálótól való különbözősége - ahogyan a „Természet lélegzetét" követi, a „Természet Hádeszéből” nő ki. Gulyás egyértelműen a Kalevala népieposz-jellege mellett foglal állást, és látszólag kapcsolódva a hagyományközösségi elven alapuló irodalomfelfogáshoz, az eposzt a népköltészetben gyökerező poézis megtestesítőjének tartja. Ugyanakkor a dantei párhuzammal a minta fontosságát emeli ki, a nyugati hálóhoz kapcsolódást. Arany János Kalevala iránti érdektelenségét annak tulajdonítja, hogy a népiség a magyar irodalomban népi-klasszikust jelentett. A Vikár-fordítás első, 1909-es megjelenésének visszhangtalanságát is erre vezeti vissza, valamint arra, hogy az Akadémia kiadásában jelent meg, mely akkoriban a „legnépszerütlenebb testület" volt. A fordítás nyelvét is kritikával illeti: archaisztikusságában és folklorisztikusságában túlságosan modorosnak tartja, ugyanakkor úgy látja, hogy Vikár fordításával éppen az Arany János-i örökséget folytatta, sőt, meg is haladta azt. Ami Gulyást mégis megkülönbözteti a Barna-, Vikár- és Kosztolányi-felfogástól, az a módszerében keresendő. Gulyásnál a finn-magyar analógiák és párhuzamok nem a finnugor őseposz rekonstruálásának szándékával kerültek előtérbe, hanem egyszerüen a rokonság hangsúlyozásának és a modellként való felmutatás szándékával. Ô a Kalevalában a magyar kultúra homéroszi lehetőségét látta: „Voltak, akik azt kiáltották: új görögséget! Én ezt kiáltom: új finnséget! De hiszen a kettő nem zárja ki egymást, sőt feltételezi." ${ }^{202}$

${ }^{202}$ GULYÁS 1985[1937]: 84. 
Ez pedig a finn eposzban válhat „eleven erővé”, természetesen a finnugor hálón keresztül.

Az 1943-as kötet utószava három szerkezeti egységben vizsgálja a finn eposzt és annak Vikár-féle fordítását: 1. Kalevaláról, 2. Bolyongás a Kalevala birodalmában és 3. Néhány Kalevala-jelenet címek alatt. Az első részben Gulyás a Kalevala finn identitásformáló szerepéről és jelentőségéről ír, hogy a svéd és az orosz uralom alatt is a finnek a Kalevalának köszönhetóen őrizték, sőt teremtették meg a finn nyelvü nemzeti irodalmat, kultúrát. A gyưjtések helyéről észrevétlenül tér rá kora politikai helyzetére: „,egy kincs fénye sugárzott át egész Finnországon, bár a kincs még aludt, lappangott messze kelet felé... A karjalai erdőségekben... Ott, ahol most az oroszok támadják a finneket... Ennek a kincsnek mágikus hatalma tartotta ébren a finn lelkeket." ${ }^{203}$ Gulyás az eposz értelmezésében az irodalmi és esztétikai szempontok mellett a Kalevala társadalmi és politikai vetületét hangsúlyozza. A hagyomány átöröklése a jövő generációjára szerinte a kis népek fennmaradásának egyedüli záloga. Az átöröklés révén válhat a Kalevala a népek ifjúságának eposzává.

Az utószóban úgy ír a finnek II. világháborús részvételéről, hogy közben a magyarok elé állít példát. A kis nyelvek és nemzetek túlélési esélyeit a kultúrán alapuló identitásmegőrzésben látja. A finn eposz a 19. században a finn nemzet létét volt hivatott bizonyítani. A szovjetek ellen folytatott háború alatt pedig a nemzeti és - tágabb értelemben - a finnugor összetartozás jelképévé vált: „,(...) a Kalevala - holott nem is ez volt a szándéka, de éppen azért, mert nem erőltette a szándékát, - a sors jutalmából s annak, aki tud olvasni belőle, -: a kis Suomi nagy magyarázata." ${ }^{204}$

\subsubsection{Politikum a világháború alatt született írásokban}

Nem csupán Gulyás Pál tanulmányáról, hanem a fordítás recepciótörténetének 1935-1944 közötti írásairól is elmondható, hogy a politikum szempontja jellemző rájuk. A háttérben - amint már említettem - a területeit vesztett Finnország és Magyarország hasonló politikai helyzete, valamint a szovjetellenesség áll. Erre az analógiára alapoznak a következő megfogalmazások: „De mi magyar testvérek is tartunk egy kis jusst a Kalevalához. (...) Karjala tudvalevöleg a finnek Székelyföldje. (...) a mi külön csodánk is megérdemelne egy kis külön érdeklődést. Legalább tőlünk - nem árjáktól" 205 „A finneknek Karjala (Karélia) a Trianonjuk. Hátsó-Karjalát a szovjet még mindig hatalmában tartja. (...) Az orosz bolseviki módszer azon-

\footnotetext{
${ }^{203}$ GULYÁS 1943: 293.

${ }^{204} \mathrm{Uo}$.

${ }^{205}$ PÁLFFI 1935: 503. [kiemelés tőlem, V. P. I.]
} 
ban lassankint úgy oldja meg a karjalai kérdést, hogy elhurcolja e derék finn nép utolsó hírmondóját is Szibériába és helyükbe oroszokat telepít"; 206 „A Kalevala egymaga képes volt örökre kiemelni a kicsi finnséget a világtörténelem homályos zugából"; 207 "A költészet nemzeti jelentőségét saját tapasztalataiból látta az anyaországi és elszakított területek magyarsága és igazat adhat Kalevala egyik dán ismertetőjének: Az idők folyamán mindig azon fordul meg a dolog, hogy az egyszer megszerzett kultúra sértetlenül maradjon." 208

Az analógián túlmenően egyes Kalevala-ismertetésekben egyfajta cselekvésre buzdításnak is tanúi lehetünk a finn eposz hősein keresztül: „A kis finn (és magyar) nép nagy lehet, ha hallgat Väinämöinenre, a Kalevala hősére, az Igézőre, akinek lantja csodákat müvel: megmozdítja a köveket, összebékíti az erdők vadjait, dallal legyőz népeket és országokat"; 209 "Ma csak annak van értelme, aminek funkciója van; mai életünk nem gyüjtő́medence, hanem sebes rohanású folyó, halálra van ítélve minden, ami nem sodor, hanem stagnál". ${ }^{210}$

Azok a folyóiratok, melyekben ezek az írások megjelentek többnyire jobboldali, a nemzeti és keresztény értékek ápolását tűzték ki célul: Turán, Protestáns Tanügyi Szemle, Új Élet, Napkelet vagy Magyar Lélek, Magyar Út, Sorsunk, Erdélyi Fiatalok.

A politikum jelenlétével a Kalevala magyar fogadtatástörténetében már Domokos Péter is foglalkozott 1972-es munkájában. Tette ezt a marxista szemléletű irodalomtörténet felől nézve: „A két világháború között éli virágkorát a turanista mozgalom is, amely számos dilettánst tömörített magában. Koncepciójába a finnugor rokonság is beleillik, s ennek következményeként a Kalevala sem mentesülhet a fajbiológiai kutatásoktól. A két ország párhuzamos és erőteljes fasizálódása idején a turanisták válnak a finn-magyar kapcsolatok szószólóivá, s különösen a szovjet-finn háború éveiben árasztják el tendenciózus írásaikkal a sajtót, s irredenta művek fordításaival a könyvpiacot". ${ }^{211}$

Domokos megállapítását túlságosan merevnek érzem ugyan, azonban a két világháború közötti időszak fellendülő kulturális és államközi kapcsolatainak vizsgálata a finn eposz magyarországi fogadtatásában nem hagyható figyelmen kívül. Az irodalmon kívüli szempontok bevonása azért is megkerülhetetlen, mert a két világháború közötti időszakhoz ha-

\footnotetext{
${ }^{206}$ CSEKEY 1936: 12.

${ }^{207}$ DL 1935: 64.

${ }^{208}$ GOMBOS 1942: 788. [kiemelés az eredetiben]

${ }^{209}$ Protestáns Tanügyi Szemle 1944/2 45.

210 SZENDE 1944: 6.

${ }^{211}$ DOMOKOS 1972: 156.
} 
sonlóan a II. világháború után, ha teljesen más politikai paradigmában is, de a politikum szempontja tovább él.

\subsubsection{Politikum a második világháború utáni írásokban}

Az 1944 utáni években a magyarországi politikai berendezkedés megváltozása az irodalomban és a fordításelméletben is paradigmaváltáshoz vezetett. A II. világháború utáni évtized a finn irodalom magyarországi megjelentetését illetően a kiadáspolitika „fagyos korszakának" tekinthető. Ez a Kalevala-kiadásokban is szembetűnő, hiszen az 1945-öt megelőző évtizedben négyszer is megjelenhetett a teljes Vikár-fordítás, az utána következő évtized első felében egyáltalán nem, utána egy szemelvényes, az 50-es és 60-as években pedig összesen kétszer jelent meg a teljes szöveg. A magyar kiadáspolitikában egyértelmű változást Finnország és a Szovjetunió politikai és gazdasági kapcsolatainak a változása hozott, aminek köszönhetően a magyar, kommunista ideológia irányította kiadáspolitika bátran felvállalhatta a különben „polgári” Finnország irodalmi termékeinek megjelentetését. Ez hatással volt a Kalevala fogadtatására is. Szopori Nagy Lajos szerint a Kalevala esetében pozitív tényezőként hatott az a tény is, hogy (az eposzszerkesztő) Lönnrot többnyire Szovjet-Karjala területén gyüjtötte anyagát. (Ez pedig újra a népeposz-múeposz, valamint Lönnrot szerzőségének kérdését vetett fel a fogadtatásban.) Ugyanez persze fordítva is igaz: a gyưjtések helye kitünő okot szolgáltatott arra, hogy a Kalevalának az új paradigmában is helye lehessen. A münek és fordításának vizsgálata úgy szolgálta ki a korabeli elvárásokat, hogy a finn eposz keletkezési helyére fókuszált és marxista-leninista elveket érvényesített a Kalevala elemzésekor, valamint a Vikár-fordítás hatását vizsgálta a kor kanonizált költőinek - József Attila és a népies költők - műveiben.

Az 1950-es kiadás Otto Kuusinennek, Szovjet-Karjala köztársasági elnökének finn nyelvű Kalevala-kiadása alapján készült. Kuusinen megbontja a finn eposz lönnroti szerkesztésmódját: témakörök és müfajok köré szervezi az eposzt. A magyar kiadás Vikár fordítása alapján készült, de a megváltoztatott szerkezet miatt kénytelenek voltak újabb sorokat betoldani. Ezeket Kormos István fordította - ahogyan később az 1959-es kiadás előszavának szerzője utal rá - Vikár Béla stílusához hűen. Az előszó szintén Kuusinen munkája, mely később, az 1950-es és 1960-as években megjelent Kalevala-tanulmányok alapjául szolgált. ${ }^{212}$

${ }^{212}$ Lásd STOLL 1950., KOVÁCS 1958., RADÓ 1967. és VAJDA 1968. 
Radó György ${ }^{213}$ tanulmányában a finn eposz és az ipari társadalom közötti analógiákra mutat rá. Igy lesz Ilmarinen kizsákmányoló, ugyanakkor műszaki értelmiségi, vagy Väinämöinen az a pogány értelmiségi, aki sértődötten utasítja el a „kereszténység-alapító Kisded” megkeresztelését, pedig „érti a dolgát”, és tudatában van annak, hogy „az autochtón értelmiségre az új társadalomnak is, mint minden társadalomnak, szüksége lesz" még akkor is, ha az eposz utolsó éneke szerint el kell hagynia Kalevalát. ${ }^{214}$ Vajda László tanulmányában Väinämöinen, a finn táltos, a vallás és a mágia - az alávetettség és a szembeszegülés képviselője egyszerre. Az utolsó énekben kifejtett väinämöineni remény a visszatérésre pedig a szembeszegülés győzelmét hirdeti a kereszténység, a vallás, az alávetettség fölött: „Egykor a mágia és a vallás közt dúlt a harc. Ma változott alakjukban küzdenek, mint tudomány meg metafizika. Amily mértékben hódítja meg a tudomány az ismeretlent, oly mértékben csökken a metafizika jelentősége $-\mathrm{s}$ oly mértékben lesz úrrá az ember magán a földön. A modern ember számára ez a Kalevala mondanivalója." 215 Stoll Béla közvetlenül is utal Kuusinen előszavára, mely szerinte hiteles magyarázata az eposznak. Kuusinen szereplőjellemzéseit alapul véve fejti ki a Kalevala mondanivalóját korának olvasói, a „,szocializmus embere” számára: „, [Kullervo például] mindenekelőtt példát mutat arra, hogyan kell érvényesíteni az igazi bolsevik pártosságot: a haladás ügyéért folytatott harcot egy évszázadokkal ezelőtt keletkezett költői alkotás elemzésében."216

1959-ben, Vikár születésének századik évfordulóján újra megjelenhetett a teljes szöveg. Az előszót jegyző - obi-ugor nyelvészettel foglalkozó Cs. Faludi Ágota finom kritikával illeti az 1950-es kiadás szerkesztésmódját: „[az 1950-es kiadás alapján] mindenesetre világosabb, hogy milyen elemekből tevődött össze a Kalevala, de valahogy elsikkad a Lönnrot-szerkesztette eposz egészének bájából valami". ${ }^{217} \mathrm{Az}$ eposz összetevő elemeire való utalás a Kalevala népeposz-műeposz jellegét megvilágító vitájával áll kapcsolatban. Amikor megkérdőjelezi a finn álláspontot, miszerint a Kalevala Lönnrot alkotása lenne, Kuusinen szövegére utal vissza és ért egyet azzal, hogy „a szkeptikus polgár" vélheti úgy, hogy a nép nem alkothatott ilyen tökéletes múvet. ${ }^{218}$

\footnotetext{
${ }^{213}$ Radó György (1912-1994) író, bibliográfus, fordító. A szovjet irodalom első népszerűsítői közé tartozik. A kisebb finnugor népek irodalmából is fordít.

${ }^{214}$ RADÓ 1967: 51.

${ }^{215}$ VAJDA 1968: 1480.

${ }^{216}$ STOLL 1950: 128.

${ }^{217}$ Vö: CS. FALUDI 1959: V.

${ }^{218}$ Uo. XXIV. [kiemelés tőlem, V. P. I.]
} 


\subsubsection{Fogadtatás a finnugor hálón kívül}

Az 1959-es kiadást követően Vikár fordítását háromszor adták ki szemelvényes formában, 1970, 1972 és 1980-ban a Diákkönyvtár sorozatban az 1950-es kiadást alapul véve. 1962-ben és 1985-ben a teljes szöveg is megjelenhetett. Az utóbbi a Helikon kiadó gondozásában látott napvilágot. Ekkor volt ugyanis a Régi-Kalevala 150. évfordulója. Bár ekkorra már két újabb fordítás is megszületett: a Nagy Kálmáné és a Rácz Istváné, valamint készen állt a Szente Imréé is, az ünnepi kiadás azonban Vikár Béla átültetése. Az utószóban Hajdú Péter vall a választás okairól: „egyetlen szempont vezérelt. Az nevezetesen, hogy a mai ízléshez bizonyosan közelebb álló újabb s talán kevésbé díszes, ám természetesebben hangzó fordításokról le kell mondani, mert Nagy Kálmán és Rácz István múveivel a hazai piac telítve van, míg Vikárnak a Kalevalát nálunk klasszikussá tevő fordítása beszerezhetetlen. Ez az indoka az archaizáló, népies-romantikus, helyenként szinte már édeskésnek ható Vikár-fordítás újraközlésének." ${ }^{219}$ A Vikár-fordítás újramegjelentetésének indoklását tehát piaci érvek bevonása jellemzi, ugyanakkor el is marasztalja a fordítást, mégpedig a nyelvezete miatt. Ez, amint arra a Nagy Kálmán- és a Rácz István-fordításokkal foglalkozó alfejezetekben is rámutatok, az 1970-es években jelentkezik erőteljesebben, miután az újabb fordítások Budapesten is megjelentek.

Akárcsak az 1935-ös jubileumi kiadás, ez is - ünnepi kiadás lévén már külső megjelenésével is különbözik a többi teljes szövegkiadástól.

A kötet borítója piros-fehér színü, vászonkötés szövetborítással, magyaros keresztszemesre emlékeztető varrásmintával. A kötet védőborítóban jelent meg: fehér alapon piros rombusz, benne a belső borítón levő mintával. Az 1985-ös kiadás magyaros borítója a finnesebb írásmóddal írt nevekkel - ä-vel jelöli a nyílt $e$ hangot, az idegenségérzetet megőrizni próbáló szövegváltozattal képez kontrasztot.

Az 1985-ös kiadás a rendelkezésre álló két fő szövegvariáns közül az 1909-es alapján készült, közli az első kiadásban megjelent fordítói előszót is. A két kiadás - az 1909-es és 1935-ös - között a legnagyobb különbség a nevek írását és az énekek előtt álló tartalmi összefoglalókat érinti. Az 1935-ös kiadásba Vikár saját költésű verseket illesztett. A szövegvariáns kiválasztásában többek között ez is szerepet játszott: „,helyesebbnek láttuk azokat a Vikártól költött sommázó és olykor bizony gyermeteg versikéknek a mellőzését, amelyet Vikár az egyes énekek elé állított."220 Az 1985-ös és az 1909-es kiadások pedig a helyesírásukban különböznek egymástól: az újabb a normatív változatot követi. Pl. a c hangot c-vel, és nem cz-vel

\footnotetext{
${ }^{219}$ HAJDÚ 1985: 332.

${ }^{220}$ HAJDÚ 1985: 332.
} 
jelöli stb. Ugyanakkor pár zavaró nyomdahiba(?) is maradt az 1985-ös szövegben. pl. „Erdőt adtát esdekelve” (1985, 14:44), valamint olyan változtatások, melyek éppen szembemennek a helyesírási normákkal. Pl. „Külömbekhez te magadnál”(1985, 11:70), „De mint bánja Lemminkäjnen”(1985, 11:103). Ezek azonban elhanyagolható különbségek, munkám szempontjából nem relevánsak.

Vikár szövegéből újabb válogatás legutóbb 2007-ben jelent meg, a Diákkönyvtár sorozatban. A válogatást is végző Voigt Vilmos utószót is írt a kötethez, amelyben a Kalevala keletkezésével, múfajával, müfaji összetettségével, versformájával, a finn kultúrában betöltött szerepével, a magyar fordításokkal és hatástörténetükkel is foglalkozik. A válogatás végzőjeként különféle változtatásokat is eszközölt a szövegen: a már alig érthető nyelvjárási szavakat köznyelviekre cserélte, a Vikár által sokszor röviden jelölt hosszú magánhangzókat hosszúakra, a nevek írásában pedig a magyar fonetikát és helyesírást követte. A szövegválasztást, hogy éppen a Vikárét használta, annak klasszikussá vált mivoltával magyarázta és azzal, hogy „talán mindmáig a legközelebb áll az eredetihez." 221 Az eredetihez való tartalmi hűség összekapcsolódva a formai hüség kérdésével, leginkább majd az újabb Kalevala-fordítások megjelenése után vált központi problémává.

\subsubsection{A fordító kultusza}

Vikár Béla szövegének fogadtatása, amint láttuk, különösen a két világháború között, más szempontok bevonását is igényelte. A többrendszer-elméleti megközelítés azt is megengedi, hogy a recepció dokumentumaihoz kultikus szempontok figyelembe vételével is lehessen közelíteni.

A következőkben tehát a Vikárhoz kapcsolódó hozzáállásban megnyilvánuló kultikus elemeket vizsgálom a már érintett, a fordító önkultusz-konstruáló stratégiájához kapcsolódva.

Dávidházi Péter irodalmi kultuszt érintő kutatásaiból indulok ki, ahol a kultusz megnyilvánulási formáit három csoportra osztja: a kultusz mint beállítódás, szokásrend és nyelvhasználat. ${ }^{222} \mathrm{~A}$ Vikárhoz való viszonyulásban tetten érhető kultikus vonásokat az első két csoport mentén vizsgálom. A kultuszról mint nyelvhasználatról a fogadtatás vizsgálatában már volt szó, mint ahogyan részben a beállítódásról is. Éppen ezért ez utóbbival csak a fordító személyéhez kötötten fogok foglalkozni.

${ }^{221}$ VOIGT 2007: 187.

${ }^{222}$ Vö. DÁVIDHÁZI 1989. 


\section{A Vikár-kultusz mint beállítódás}

Ez a fajta rajongó tisztelet különösen az etnográfus és fordító Vikár személyének szól. Bár etnográfusként, népdalgyüjtőként manapság már sokkal inkább csak Bartók és Kodály elődjeként emlegetik, ebben a hozzáállásban is felfedezhető a szerény és önzetlen Vikár iránti mindenek fölötti tisztelet. Ezt a képet maga Vikár is erősítette. Önmagát szerény tudósként láttatta, aki mentora, támogatója volt - szellemileg és anyagilag is - a fiatal pályakezdő tehetségeknek. József Attila egyike a kiemelt fiataloknak, akik tisztelettel, csodálattal, szeretettel és ragaszkodással tekintettek Vikárra, és akik megélhetési nehézségeik idején is Vikártól kaptak támogatást. ${ }^{223}$ Kodály Zoltán és Bartók Béla a másik két kiemelt, akik a Vikár megkezdte gyưjitéseket folytatták. Az átöröklés momentumát Volly István magát Vikárt idézve a következőképpen meséli el: „Odakölcsönöztem neki a fonográfot, Petőfi szellemében: mit én nem egészen dicstelenül kezdék, / folytasd Te, barátom, teljes dicsőséggel! A két ifjú zenetitán akkor 22-23 éves volt, Vikár pedig 45. Nem volt féltékeny a fiatalokra." ${ }^{224}$

Kalevala-fordításának megjelenésekor - amint láttuk - szerencsésen ötvözhetővé vált az etnográfus és a fordító Vikár képe. Még életében, hetvenedik születésnapjára olyan köszöntő cikkek jelentek meg, melyekben Vikár „,a magyar kultúra viharcibált, de tisztes épületének sok szépen faragott, hatalmas írásos kövét"225 lerakó mestereként jelent meg. Széles spektrumú munkásságából a népköltészeti gyưjtéseit és fordításait emelték ki. A halála után megjelent nekrológban Gombos László a „prófétafőre” emlékezik, akinek elvesztése miatt „egy egész nemzet a kárvallott”. Ugyanitt azt is kifejti, hogy bármennyire is úttörő munkát végzett Vikár, mégis elhagyatottan kellett meghalnia: „Vikár Béla útja behálózta az egész országot, kivezetett a közeli és távoli Európa, sőt az európaiság felé, de nem torkollott az elismerés mauzóleumába. Elmondhatjuk róla, hogy hamar felejtették el, sőt még azt is, hogy észre sem vették, mikor elköltözött. Belekaparták a közönynek útszéli árkába, holott ő maga út volt, melyen többek között Bartók jutott tovább, a megérdemelt világhír felé. És Bartóknak egy világ hódolt, de senki sem őszintébben, nagyobb hozzáértéssel, tudatosabban, mint Vikár Béla. Vikár Béla sohasem irigyelte mások dicsőségét és ha egyáltalában fájhatott neki valami, akkor az csak az volt, hogy életútjának nem minden mellékösvényén akadt elég és érdemes utas." 226 Vikár 1945. szeptember 22-én halt meg Dunavecsén, pár évvel később, 1948. október 23-án temették újra Budapesten.

\footnotetext{
${ }^{223}$ SCHELKEN 1969b: 55-58.

${ }^{224}$ VOLLY 1959: 56.

${ }^{225}$ VARRÓ 1929: 229.

${ }^{226}$ GOMBOS 1946: 5-6.
} 
A Kalevala mellett La Fontaine meséiből is fordított, a grúz Rusztaveli munkájának magyarra ültetése pedig jó okot adott arra, hogy polihisztorként, nyelvzseniként jelenhessen meg. A sok idegen nyelvet beszélő Vikárról legendák születtek: pl. amint egy haldokló katonához annak anyanyelvén, mingrél nyelven szól. ${ }^{227} \mathrm{Ez}$ a történet folklorizálódik tovább a Vikár Bélát eltemető református lelkész, Molnár Lajos két emlékező írásában. ${ }^{228}$ A kettő közti legszámottevőbb különbség az, hogy a későbbiben a forrást is megjelöli. Ugyanakkor meglehetősen le is rövidíti, és a katona utolsó mondatait az írást publikáló lap - a Theologiai Szemle - profiljához igazítja: „Te angyal vagy, akit Isten elküldött, hogy halálom előtt az én nyelvemen halljam az örömüzenetet."229

A Rusztaveli-fordítás késztette Zempléni Árpádot ${ }^{230}$ is levélírásra. A levél később az 1935-ös Kalevala-kiadás Magyarázatok a Kalevalához című kötetében jelent meg többek között Kosztolányi Dezső esszéje mellett. Csakis Vikárnak tulajdonítható, hogy e levél bekerülhetett a kötetbe, hiszen a kötet borítóján az ő neve szerepel, és egy hozzá intézett levélről van szó. A levél annál is érdekesebb, mivel 1917-ben íródott, és a grúz Rusztaveli művének fordítása kapcsán kapta Zemplénitől a fordító. Azonban

${ }^{227}$ „A mingrél fogoly. Egy jóarcú, szerény, kedves orosz fogoly került Budapest környékén egyik fogolytáborunkba. Beteg volt már elfogatásakor szegény. Tüdőlövés érte és fogyott, sorvadt arcára kirajzolta már a halál az ő sárga-piros rózsáit. Nagyon szenvedett a fiú. Nem tudta senki megvígasztalni. Egy szót sem értett oroszul, de az orosz katonák közül sem tudott vele beszélni senki. Az oroszok nem tudták megfejteni, hogy milyen fajtájú, nyelvű az idegen ezredből egyedül közéjük pottyant beteg katona.

Már haldoklott. Látszott rajta, hogy beszélni akar valakivel. Egy rövid kis üzenetet haza, isten tudja hová. Kértek kirgizt, osztjákot, cserkeszt, csecsencet s tudja Isten kit még, a nagyobb orosz fogolytábortól. De senki nem tudott vele beszélni. Végre egyik kitűnő tudósunkhoz, Vikár Bélához fordultak a mi gyémántlelkủ ápolónőink, hátha ő tudna beszélni a haldokló orosszal?

Vikár ki is ment hozzá. Szólt hozzá finnül, osztjákul, sorban egy csomó nyelven. Az orosz nem értette. Végre is, amikor már reménytelennek látta a dolgot, megszólította mingrélül. A fogoly szeme felvidúlt, zokogni kezdett, mint a gyermek, csókolta a tudós kezét... Mingrél volt, a Kaukázus e kis, alig ismert hercegségéből, ahova a colchisi aranygyapjú keresésének legendája füződik...

... Beszélt, beszélt. Kiöntötte a lelkét. Hat hónapja nem beszélt már... A tudós vígasztalta: - Jobban leszel, fiam. Meggyógyulsz...

A mingrél megsimogatta erre a Vikár kezét és szólt:

- Tudom én: ki vagy. Te vagy az angyal. Én már meghaltam s akkor jöttél le te, az angyal, hogy megvígasztaljál, hogy beszélj velem anyámnak nyelvén. És én boldog vagyok, hogy ha halálom után is -, de mégis még egyszer beszélhettem és hallhattam őseim nyelvét..." (Új Idők 1916. április 9. 16. szám, 393. Pillanatfelvételek rovatban.) [kiemelés tőlem, V. P. I.]

${ }^{228}$ Lásd MOLNÁR 1962. és 1970.

${ }^{229}$ MOLNÁR 1970: 374.

${ }^{230}$ Zempléni Árpád (1865-1919) költő, műfordító. A kisebb rokon népek költészetének felfedezője és első sikeres tolmácsolója a magyar irodalomban. A turanista mozgalom egyik kezdeményezőjeként tartják számon. 
nem véletlenül éppen ez a levél került publikálásra. A fordító Vikárhoz és Vikáról szól, középpontjában a nyelv áll: „Fordításod nyelve, verselésed múvésziessége még engemet is meglepett, aki pedig a Kalevala révén már régóta legjobb nyelv-müvészeink között tisztellek. (...) valóságos üdülés, nyelvfürdő könyved olvasása. Ily szépnek a magyar nyelvet sokan nem is hiszik. (...) Fogadd érte hódolatomat. Isten éltessen! Ölel Zempléni Árpád (1917. június 3. Bp.)". ${ }^{231}$

Nem túlzás tehát kijelenteni, hogy a fordító saját és - közvetve - a Kalevala kultuszát kívánta szolgálni a levél megjelentetésével.

Vikár vezetéknevéhez két történet is kötődik. Az egyiket Korompay Bertalan idézi, amely szerint Vikár a FIT centenáriumára írt köszönő levelét „The Vicar of Kalevala”-sorral zárta, melyet Korompay teljesen jogosnak is vél, hiszen - amint írja - Vikár egész munkássága a Kalevala-fordítás szolgálatába állítódott.

A másik, a Molnár Lajos által kétszer is idézett történet sokkal inkább a néppel való egységét, a nép nyelvén beszélni tudó fordítót állítja a középpontba. ${ }^{232}$

A néphez való tartozás rendkívüli fontossággal bír a Vikár-kép megrajzolásakor. Hiszen a „népköltés buzgó apostola” csak olyan személy lehet, aki a népből jön, „,a legmagyarabb nép öléből támad” és akinek „,apró kis korától a magyar nép lelkének legszebb hajtásait keresi szíve." ${ }^{233}$

${ }^{231}$ ZEMPLÉNI 1935: 119-120. [kiemelés az eredetiben]

${ }^{232}$ „Az első világháború idején vöröskeresztes megbízott volt Vikár. Ebben a minőségében vidéki ellenörző körútra is kiküldték. Egy ilyen alkalommal sürgönyileg jelezte $X$ nagyközségnek: Déli vonattal érkezem. Vikár. Mikor aztán kiszállt a vonatból, az állomáson nagy tömeget látott. Nem tudta mire vélni a dolgot, mert rajta kívül nadrágos ember senki sem szállott ki a vonatból. A virágos, zöldágas kapunál, fehérruhás kislányok csapata előtt látta a plébánost a község vezetőségével együtt. Érdeklődésére azután megtudta, hogy a nagy felvonulás az apostoli vikáriusnak szólt, akit Vikár sürgönye alapján várt a község népe. Látva a csalódott arcokat és a hazafelé cihelődő ünneplőket, Vikár odament a község egyik vezető emberéhez és bemutatkozott neki ilyenformán: Kérem én Vikár Béla vöröskeresztes megbízott vagyok. Tudom, a sürgöny alapján nem engem vártak, hanem az apostoli vikár urat. De nincsen semmi baj, hiszen én is Vikár vagyok. És mivel éppen az apósomtól jövök, én vagyok az apóstóli Vikár. Majd az ünnepi ebédet is elfogyasztjuk jó egészségben. (Dr. Pap Sándor országgyülési gyorsirodai fönök közlése) [Mit volt mit tenni? Az arcok felderültek és az ünnepi ebéden részt vevő Vikár Bélát annyira megszerették, hogy máskor is szívesen látták. Akkor is, ha nem éppen apóstóli Vikár volt.]" MOLNÁR 1962: 3. és 1970: 374. Forrásközlés csak a második írásban, a zárójeles rész pedig csak az elsőben szerepel. [kiemelés az eredetiben]

${ }^{233}$ VARRÓ 1929: 229. 


\section{A Vikár-kultusz mint szokásrend}

A születésének és halálának évfordulóin rendezett ünnepségek, zarándoklatok a polihisztor Vikárt idézik. A szervezett ünnepségekre meghívott magas rangú vendégekkel - például akadémiai tagokkal - Vikár teljes munkásságát próbálják lefedni. A müsorszámok is ehhez idomulnak. Kitüntetett helyen azonban a Kalevala áll.

Az 50-es évektől a 80-es évekig születésének és halálának évfordulóján emléküléseket, emlékünnepélyeket szerveztek, majd ezeknek a kultikus fesztiváloknak az anyagát a Somogy Megyei Tanács kötetben jelentette meg. A kötetek a köszöntőbeszédeket és a vendégek névsorát is tartalmazzák. Ez utóbbi azért érdekes számunkra, mert a Kalevala-fordítás okán a finn díszvendégek között volt például Väinö Kaukonen Kalevala-kutató is.

Születésének 100. évfordulóján jelent meg a tervezett Vikár-életrajz rövid változata. ${ }^{234}$ Ebben az emlékünnepségekről is olvashatunk: „,nemcsak Magyarországon, de külföldön is ünnepelték őt, így Finnországban és a Szovjetunióban [a Rusztaveli fordítás okán - V. P. I.]. Az ünnepi megemlékezések sorát a Somogy megyei Hetes falu nyitotta meg 1955. november 26-án, mintegy félezer hetesi földmüves jelenlétében, a kaposvári óvónőképző énekkara és Pöttendi Lidi néni, Vikár hetesi népdalénekese szereplésével. Leleplezték a Vikár-emléktáblát, emlékbeszédet Takáts Gyula író és Volly István mondott." ${ }^{235}$ A rendkívül gazdag program egyaránt kívánt emléket állítani az etnográfus, a fordító, a gyorsíró és az irodalomszervező Vikár Bélának. ${ }^{236} \mathrm{~A}$ néprajz és zenekutató Volly István felkereste azokat a

${ }^{234}$ VOLLY 1959. A Schelken Pálmával közösen írt életrajz végül nem jelent meg. Ma a kb. 600 oldalas kézirat a budapesti Hagyományok Házában található Ideje volna énekelni cím alatt. Schelken Pálma egyik levelében, melyet a helsinki egyetem magyar lektorához, Weöres Gyulához írt 1962-ben, még reménykedett, hogy az Akadémiához beadott kézirat megjelenik. Az Akadémia levéltárában végzett kutatásaim nem vezettek eredményre. Annak, hogy egyáltalán felvették volna az életrajzot a kiadandó művek listájára, nem találtam nyomát. Valószínủleg Schelken nem fogalmazott elég világosan, és a kézirat nem az Akadémiához, hanem az Akadémiai Kiadóhoz került. Mindenesetre Ortutay Gyula az 1969-es ünnepség záróbeszédében így nyilatkozott: „Vannak szerzők, akik túlírják műveiket és nincs szívük egyetlen betűt sem törölni. A két szerző gondos, alapos munkával minden morzsalékot összegyưjtött hőséről." BÉRES - HEISZ - KLUJBER 1970: 108.

${ }^{235}$ VOLLY 1959: 62.

${ }^{236}$ A programról bővebben: „Somogy megyében a centenárium alkalmával sorozattá nőttek a Vikár-emlékezések. Ismét a szülőfalu nyitotta meg a sort. 1958. április 13-án a centenáriumi előkészítés alkalmával - a Kadarkúti Földművelésszövetkezeti Vegyeskar, az ünnepi alkalomra alakult Hetesi Férfikar, a Vikár Béla úttörőcsapat, Pettendi Lidi néni és Korcz Józsi bácsi, Vikár egykori népdalénekesei szerepeltek. 1959. április 1-én - a centenárium napján - a Balatonboglári Járási Múvelődés Ház - mely a balaton-táj legszebb háza - Vikár Béla nevét vette fel. Homlokzatát Vikár-relieffel díszítették. A vendégszereplő Csepeli Vasmű Menyecskekórusa ajkán felcsendültek Vikár Somogy megyei népdalai. Április 5-én Budapesten, a Farkasréti temetőben megkoszorúzták Vikár Béla síremlékét. A MTA nevében Ortutay 
falvakat, ahol az 1800-as évek végén és 1900-as évek elején Vikár is gyüjtött, és a még élő énekesekkel interjút készített, melyet szintén a Somogy Megyei Tanács jelentetett meg.

1969-ben, születésének 110. évfordulójára, a 100. évfordulót is túlszárnyaló ünnepségeket szerveztek Kaposváron és Hetesen, Vikár szülőfalujában is. Az MTA, a Néprajzi Intézet és az ELTE munkatársai mellett két finn vendége is volt az ünnepségeknek: Väinö Kaukonen Kalevala-kutató és Erkki Ala-Könni, népzenekutató. A finn zarándokok kiemelt helyet foglaltak el a vendégek sorában. Ezt támasztja alá az a tény is, hogy az ünnepség záró részében Ortutay Gyula mellett egyedül ők szólalhattak fel. Koszorúzásukról pedig az egyik szervező, Kanyar József így ír: „Megható volt a két tudós zarándok arcát célhoz érten látni a hetesi ünnepségen, amikor ünnepélyes áhitattal helyezték el babérkoszorúikat a szülőfalu emléktábláján."237

Érdemes azt is megfigyelni, milyen széles spektrumot fognak át azok a folyóiratok, amelyek Vikárról megemlékeznek: Muzsika, Magyar Nyelvör, Köznevelés, Jelenkor, Reformátusok Lapja, Theologiai Szemle, Nyelvtudományi Közlemények, Századunk, Etnographia, Napjaink, Somogyi Honismereti Híradó, Irodalomtörténet.

Szülőfalujában, a Somogy megyei Hetesen, bár szülőháza már nem áll, a Polgármesteri Hivatalon található tábla őrzi Vikár Béla emlékét. Az úttörő mozgalom idején Kaposvár környékén a legtöbb úttörőcsapat Vikár Béla nevét viselte, napjainkban pedig a vegyeskar őrzi emlékét. 2009-ben, Vikár születésének 150. évfordulóján, gyưjtést indítottak egy emlékház megnyitására, melynek egyik szobáját Vikár emlékének szentelik. ${ }^{238}$ Halá-

Gyula akadémikus, továbbá a néprajzi Társaság, a Magyar Gyorsírók Szövetsége, Dunavecse küldöttei, a Finn Követség és Somogy megye helyezett koszorút. Emlékbeszédet mondott Pap Sándor parlamenti gyorsíró, Vikár Béla hivatali utóda. - április 26-án ismét Hetes népe ünnepelte nagy fiát: s szabadtéri dalos-táncos ünnepélyen jelen volt az egész falu, ünnepi beszédet Ortutay Gyula mondott. A Somogy megyei Népi Együttes Vikár által gyüjtött népdalcsokrot adott elő Kanyar József összeállításában. Május 2-án a Marcali Művelődési Ház tartott Vikár emlékestet, amelyen Vikár somogyi balladái, Kalevala-fordítása hangzott el és Gergely Pál emlékezett meg tudós tanítójáról. Közremüködött a Csepel Művek Központ Énekkara és Jancsó Adrienne előadóművésznő. Május 4-én Kaposvárott a Somogy megyei Népi Együttes a tízéves jubileumi hangversenyén is megemlékezett Vikár Béláról. Május 11-én a Somogy megyei Vikár Béla Centenáriumi Emlékbizottság rendezésében a Kaposvári Csiky Gergely színházban a megyeszékhely ünnepelte Vikár Bélát. Az ünnepi beszédet Csákvári János, a Somogy megyei Irócsoport titkára mondta. Vikár Béla finn, grúz, francia műfordításaiból, a Kalevalából, a grúz eposzból, La Fontaine meséiből Jancsó Adrienne, Lóránd Hanna, Bodor Tibor, Somogyvári Pál, Horvát Sándor színművészek adtak elő. Közreműködtek a kaposvári Liszt Ferenc kamarakórus, a Liszt Ferenc szövetkezeti leánykórus és a zeneiskola tanárai, B. Itzés Irma, Jaczkó Gyula, Tátrai Irma, Kósa Sándor, Nagymiklósi József és Nyakas József. A műsort összeállította és az összekötő szövegeket Schelken Pálma írta." Uo. 62-63

${ }^{237}$ BÉRES - HEISZ - KLUJBER 1970: 12.

${ }^{238} \mathrm{http}: / /$ www.hetes.hu/index.php?mode=4 Letöltve 2010. augusztus 10. 
lának színhelyén, Dunavecsén utcát neveztek el róla, valamint Vikár nevét viseli a Városi Könyvtár és a Művelődési Ház is. ${ }^{239}$ Ugyancsak itt emlékeznek meg minden évben Vikárról február 28-án, a Kalevala-nap apropóján. Az ünnepi müsorban minden évben szerepel olyan személy, aki valamiféleképpen kötődik a finn kultúrához vagy Finnországhoz. ${ }^{240}$

Vikár születésének 125. évfordulójára, 1984-ben jelent meg Laczkó András szerkesztésében a Vikár Béla nyomában címủ kötet. A korábban megjelent kötetektől a nyelvhasználata és a Vikár Bélához való viszonyulása különbözteti meg. Ami a nyelvhasználatot illeti, kevésbé jellemző rá a metaforikusság vagy az elragadtatottság. Egyedül az életrajzíró Schelken Pálma képez ez alól kivételt. A szerkesztó Laczkó András a Vikár és a La Fontaine Társaság kapcsolatát, Vikárnak a Társaságban végzett munkáját vizsgáló tanulmányában arra mutat rá, hogy sem az Akadémia nem választotta rendes tagjává, és hogy a Petőfi és Kisfaludy Társaság sem méltányolta kellőképpen Vikár munkásságát.

Születésének 150. évfordulóján a Magyar Tudományos Akadémián Vikár-emlékülést tartottak. Az előadások ismét igyekeztek az etnográfus, a fordító, a gyorsíró és az irodalomszervező Vikár Bélának is emléket állítani. ${ }^{241}$

\section{3. Összegzés}

Összefoglalásképpen lássuk, mi jellemző általánosságban és a fordítókhoz/fordításokhoz kötötten a Kalevala magyar fogadtatására.

Ami a fordításokról szóló írásokat és múfajukat illeti, általánosságban elmondható, hogy legtöbbjük ismertetés és recenzió. Meglehetősen kevés a tanulmány. Az írások szerzői, kevés kivételtől eltekintve, a finnugor/uráli nyelvészettel és irodalommal, kultúrával vagy néprajzzal foglalkozók közül kerültek ki. Megfigyelhető egyfajta diakrón hullámzás, mely tetőpontját a két világháború között és a II. világháború alatt érte el. A finn irodalom magyarországi fogadtatásával összevetve azonban a többi finn irodalmi múhöz képest a Kalevala mindenképpen kiemeltebb helyet foglal el. Amint Szopori Nagy Lajos is rámutatott, nemcsak időbeni hullám-

\footnotetext{
${ }^{239} \mathrm{http}: / /$ www.dunavecse.hu/rovatok/intezmenyek/kult/ Letöltve 2009. január 18.

${ }^{240}$ Jaakko Kaurinkoski, Finnország nagykövete (1998); Rigina Turunen, a Szegedi Egyetem finn lektora (1999); Teemu Kokko, főiskolai tanár (2003); Csepregi Márta, az ELTE Finnugor Tanszékének docense (2006); Szíj Enikő, az ELTE Finnugor Tanszékének docense (2007); Koppányi Miklós, a Magyar-Finn társaság alelnöke (2008), Hernádi Réka, a Kalevala Baráti Kör titkára (2009). Aranyi Ágota, a dunavecsei Vikár Béla Művelődési Ház és Könyvtár vezetőjének szíves közlése.

${ }^{241} \mathrm{http}: / / \mathrm{mta} . h u /$ cikkek/vikar-bela-emlekules-121481 Letöltve 2010. augusztus 10.
} 
zás figyelhető meg a finn irodalom magyarországi fogadtatásában, hanem szinkrón is. A Kalevalán kívüli finn múvekhez való viszonyulásban érdektelenség, oda nem figyelés vagy éppen elnéző udvariasság figyelhető meg szakmai (irodalmi) és egyes társadalmi körökben is. ${ }^{242}$

Barna Ferdinánd fordításával egy finnugor háló letéteményese kívánt lenni. A célkultúra egyik részrendszerében ez sikerült is. Azonban ez a részrendszer nem tartozott az irodalmi központ rendszereihez. Barna elöszavában és a jegyzetekben háttérbe szorult a nyugati hálóra hivatkozás, azoknak a hasonlóságoknak a kiemelése, melyek a Kalevala múfajiságát előtérbe helyezve a homéroszi eposzokkal helyezik egy sorba a finn müvet. Ezzel szemben a fordító a finnugor hálóra helyezte a hangsúlyt. A Barna Ferdinánd kínálta saját idegen volt, maradt, mivel a finnugor háló megteremtésére tett kísérlet a hagyomány folytonossága híján nem lehetett sikeres. A csak rokonsági alapú kontinuitás, a jegyzetekben különféle etimologizálásokra támaszkodva, nem volt elégséges a folytonosság érzékeltetésére. Úgy is fogalmazhatunk, hogy a finnugor háló megteremtésére tett kísérlet a túlságosan is egyedítő törekvésen bukott el: a felmutatott finn-magyar analógiák ugyanis a fordító egyéni alkotásainak hatottak és csak keveseket győztek meg. A müködtethető párhuzamok, analógiák és kapcsolódási pontok a müfajt illetően adtak mintát.

Az 1970-es évekbeli rehabilitációja arra enged következtetni, hogy Barna munkájának újrafelfedezéséhez a fordításelméletben bekövetkezett horizontváltásra volt szükség. Azonban nyelvezete ekkorra már elavulttá vált.

Vikár célkitűzéseiben Barnához hasonló elveket fogalmaz meg. A finn eposz magyar átültetésekor az első két fordítót, Barna Ferdinándot és Vikár Bélát, a fordítások előszavai szerint is, a hiányzó magyar eposz pótlása vezérelte. Ugyanez a gondolat - és óhaj is egyben -, hogy a Kalevala esetleg funkcionálhatna a nyelvrokonság okán magyarként, a fordításokról írt ismertetésekben, recenziókban és esszékben többször is felbukkan. Ezzel hozható összefüggésbe a Vikár-fordítás népkönyvvé tételének szándéka is.

Az a tény, hogy Kosztolányi Dezső írta a bevezető esszét a Kalevala jubileumi kiadásához, Vikár jó irodalompolitikai érzékéról tanúskodik. A második fordító Kosztolányi személyén keresztül próbálta a Kalevalát a magyar irodalmi középpontba juttatni.

A két fordító közötti legnagyobb különbség Vikár tudatosságában keresendő. Tudatos fordítóként a végrímes és a felező nyolcas sorokban való fordítást tartotta egyedül lehetséges megoldásnak, ami tökéletesen beleillett korának poétikai felfogásába. Honosító fordítását a fogadtatásban a

${ }^{242}$ Vö. SZOPORI NAGY 2002. 
poézisen alapuló irodalomfogalomhoz kapcsolták, annak kiteljesítőjeként tekintettek szövegére. Bár Vikár sem tartozott az elismert költők közé, önmagát nem a kevésbé sikeres költő, hanem a tudatos népzene- és népköltészet-kutató szemszögéből láttatta. Ezzel magyarázta a fordításában előforduló népnyelvi és archaikus szavak jelenlétét is. Formai megoldásaival és szókincsválasztásával is a hagyomány folytonosságát hangsúlyozta.

Barna Ferdinánd és Vikár Béla is arra próbált(ak) rámutatni, hogyan is lehetne a finnugor rokonság jegyében a finn eposzból kölcsönvett eszközökkel létrehozni a magyar nemzeti nagyelbeszélést. Hogy ez egyiküknek sem sikerült, az a nemzeti nagyelbeszélés müfaját érintő 19. század végi változásoknak is tulajdonítható. Ekkor ugyanis a magyar kulturális centrum már nem az eposz müfajában látta annak megvalósíthatóságát. Vikár és fordításának sikere az (ön)kultusz-konstruáló stratégiák mellett a finnugor háló sikeres megteremtésének tulajdonítható: egyfelől a fellendülő kétoldalú (magyar-finn) kapcsolatok kedvező helyzetet teremtettek, ami a Kalevalát vagy éppen a finn irodalom magyarországi fogadtatását illeti, másfelől pedig a kontinuitás múködtetése mellett a kulturális és politikai párhuzamokra hangsúlyt fektető értelmezések/írások hatottak a fordítás kanonizálttá válásának folyamatában.

Az előbbiek figyelembe vételével az öt teljes fordítás összehasonlító vizsgálata előtt a következő elvárások fogalmazódnak meg:

- Barna Ferdinánd célkitűzéseiben a finnugor háló - ezen belül pedig - egy finnugor és magyar mitológia letéteményese kíván lenni. A fordításkiadás etimologizálásai és magyar vonatkozású jegyzetei a szövegben is érvényre jutnak.

- A forráskultúrára utaló elemeket csak akkor tartja meg, ha valamilyen módon a magyar kultúrához kapcsolhatóak.

- Vikár Béla, elődjéhez hasonlóan, a finnugor háló megteremtését tüzte ki célul. A szóhasználat terén, a magyar népköltészetből és dialektusokból is merítő célszöveg ezt szolgálja.

- A célnyelvi befogadóhoz úgy hozza közelebb a szöveget, hogy a legtöbb idegenséget hordozó, a finn kultúrához köthető elemeket a magyar kultúrához igazítja. Ez a stratégia érvényesül a formai megvalósításban is: a felező nyolcas sorok és a végrímes formai megoldás választásában. 



\section{PARADIGMAVÁLTÁS A FORDÍTÁS- ELMÉLETBEN - ÚJ MAGYAR KALEVALÁK}

1970 után három új Kalevala-fordítás is megjelent gyors egymásutánban: Nagy Kálmáné 1972-ben, Rácz Istváné 1976-ban és Szente Imréé 1987-ben. Adódik tehát kérdés, mi hívhatta életre ezeket az átültetéseket? Legkézenfekvőbb magyarázatként az eltelt évtizedekben a magyar közés irodalmi nyelvben, valamint a fordításról való gondolkodásban bekövetkezett változásokat említhetjük, melyek újfajta elvárásokat állítottak a fordításokkal szemben, így a kanonizált Vikár-fordítással szemben is. A következőkben azt vizsgálom, milyen tényezők működtek még közre az új fordítások létrejöttében, valamint azt, hogy az újabb fordítások valóban a Vikárétól teljesen eltérő stratégiának az eredményei-e.

\subsection{A fordításról való gondolkodásról a magyar többrendszerben}

Lássuk tehát először, hogyan is gondolkodtak a magyar többrendszerben a fordításról, milyen változások következtek be a fordítással szemben támasztott (szak)olvasói elvárásokban. Mivel az első teljes Kalevala-fordítás 1871-ben jelent meg, a 19. század közepétől tekintem át vázlatosan a magyar fordításról való gondolkodás főbb irányait. Az áttekintés szubjektív, néhol a túlságosan is radikális elveket emeltem ki, mivel igyekeztem azokat a fontosabb csomópontokat megtalálni, melyek leginkább hatottak az újabb fordítások fogadtatásában.

\subsubsection{A 19. század közepétől a nyugatosokig}

A 19. század végének és a 20. század elejének fordításról való gondolkodására a célnyelvi kultúra és a célnyelvi befogadó középpontba helyezése a jellemző úgy, hogy valamiféle ekvivalenciát feltételez a forrás- és 
célrendszer elemei között. Ahogyan Cserney József 1902-es munkájában megfogalmazza: „az eredeti és a fordítás ugyanazon gyönyört költsön az olvasóban". ${ }^{243}$ A műfordítás-történet kérdését vizsgálva a magyar irodalomban négy fontosabb mozzanatot különít el: a Magyar Museum, Kazinczy Ferenc (és a vele szemben álló Döbrentei), Toldy Ferenc és Szász Károly köré szerveződőkét. Utóbbi a formai hűséget hangsúlyozta. A formai hűség szempontja azért vált fontossá, mert - Szász meglátásában a magyar nyelv „megerősödött, gazdagodott, jeles költőink hajlékonnyá, fordulatossá tették; nem oly merev többé, hogy az idegen formákba bele kelljen törni, könnyen azokhoz simul". ${ }^{244}$ Hogy ez a felfogás mennyire nem volt általános, azt bizonyítja a formai hűség kérdésében ellenkező állásponton levő Radó Antal, aki az 1909-ben megjelent $A$ fordítás müvészete címü müvében szempontokat adott a fordítások kritikai vizsgálatához. Radó könyvében a fordítás és a müfordítás terminusok meghatározása után a múvészi fordítás vagy műfordítás (folyamat és produktum) jellemzőit négy pontban foglalta össze:

- az idegen munka megértése és átérzése

- az anyagi hüség

- az alaki hüség

- általános észrevételek ${ }^{245}$

A megértés és átérzés közötti (fokozati) különbségtevéssel Radó tulajdonképpen a fordítás és műfordítás közötti különbséget írta le: „,az eredeti megértése kétségtelenül legelső kelléke a müfordítói tevékenységnek, de ha ez a tevékenység költői munkára irányul, akkor a puszta megértés nem elég; az átérzésnek is hozzá kell járulnia." ${ }^{246}$ Ebből kiindulva vélte úgy, hogy ,jó müfordító csak igazi költő lehet". ${ }^{247}$ Hogy ez az elv milyen mértékben befolyásolta a 19. század végének irodalmi gondolkodását, azt Barna Ferdinánd Kalevala-fordításának fogadtatása jól példázta. Akárcsak Radónak egy másik megállapítása, mely a nyelv (forrás- és célnyelv) és fordító viszonyára vonatkozik: „A jó müfordítónak nem az a dicsősége, hogy idegen nyelvet ért, hanem hogy ura a magáénak." ${ }^{248}$ Az első Kalevala-fordítás korabeli fogadtatásában éppen e két elvet kérték számon a fordítón. ${ }^{249}$

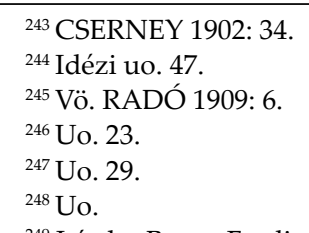

${ }^{249}$ Lásd a Barna Ferdinánd fordításának fogadtatásával foglalkozó részt, abban is a Vikár idézte Budenz-reagálást Barna fordítására: „Barna Ferdinánd kedves barátom művének két hibája van. Az első az, hogy ő nem tud elég jól finnül. De ez csak a kisebbik hiba. Sokkal nagyobb az, hogy magyarul sem tud olyan jól, mint a Kalevala fordítójának tudnia kellene. Ő nem 
A tartalmi és formai hűség leírásakor Radó a fordítástól olyasfajta egyensúly megteremtését várta, amely a célnyelvi befogadót tartja szem előtt úgy, hogy annak a forrásnyelvi befogadóval teljesen ekvivalens szerepet szán. Véleménye szerint formailag a fordítás akkor hủ az eredeti műhöz, ha „a fordítás alakja ugyanazt a hatást teszi a fordítás olvasójára, melyet az eredeti alakja tesz az eredeti olvasójára." ${ }^{250}$ Ezzel a felfogásával ahhoz az elgondoláshoz kapcsolódik, melyet egyfelöl Toldy (akkor még Schedel) Ferenc még az 1843-ban megjelent $A$ múfordítás elveiról251 címü munkájában vagy később, 1861-ben Arany János ${ }^{252}$ vetett fel.

A tartalmi hüség dolgában is a formai követelményekhez hasonlóan kell eljárnia a fordítónak. Meg kell tartania mindent, ami a forrásnyelvi szerző stílusára jellemző, ugyanakkor a forrásnyelvi jellegzetességeket, a forrásnyelvi kultúra jellemzőit el kell hagynia, és célnyelvi sajátosságokkal visszaadnia: „,a fordításnál oly szavakat kell használnunk, melyekből a mi olvasónk ugyanazt fogja kiérteni, a mit az eredetiből kiért az eredetinek az olvasója." 253

A Kalevala-fordítások szempontjából a legfontosabb Radó formahüségről vallott felfogása, különösen az antik versformák magyarra ültetéséről. A 19. század végi fordítók a versforma magyarítását tartották optimális megoldásnak. Az Arany által is javasolt honosító fordítói módszert Radó Antal a forrás- és célnyelvi olvasó befogadás-ekvivalenciájának oldaláról közelítette meg: „a klasszikus versmértékek, kivált az utóbbi időben, egészen kikopván a használatból, a nagyközönségnek, kivált a klasszikus iskolázottság nélküli olvasónak, fölötte idegenszerűek, tehát nehezen férkőznek a lelkéhez. Ha így azok számára akarjuk hozzáférhetővé tenni az eredetit, a kik azt latinul vagy görögül nem élvezhetik, a kiknek a klasszikus ritmusok, hogy úgy mondjam, nem mentek át a vérükbe, sokkal könynyebben fogunk czélt érni modern versmértékkel."254 Barna Ferdinánd és Vikár Béla Kalevala-fordításait a 20. század második felében éppen formai megoldásaik (többek között a rímes felező nyolcas sorok) miatt bírálták. Pedig a két fordító - különösen Vikár - nem tett mást, mint honosította a finn versformát, amikor felező nyolcasokban fordította a finn eposz nyolc szótagos sorait.

elég költő ehhez. Azért fordítása nem is igazi Kalevala, hanem csak holmi Barnevala." VIKÁR 1936: 68. [kiemelés tőlem, V. P. I.]

${ }^{250}$ RADÓ 1909: 79.

${ }^{251}$ Vö. SCHEDEL 1843.

252 "Ama régi formák, bármily alkalmas is zengő nyelvünk a görög-római mérték visszaadására, nem képesek a magyar lélekben azt a zenei viszhangot költeni, melyet egykor az illető nép keblében költötték." ARANY 1962c: 163.

${ }^{253}$ SCHEDEL 1843: 38.

${ }^{254}$ RADÓ 1909: 92. 
Radó fordítással szembeni elvárásrendszere mindentudó fordítót igényel. Olyat, aki az eredeti művet formailag és tartalmilag is kitűnően ismeri, az eredeti szerzojéhez hasonló habitussal rendelkezik, és így a fordítás folyamatában a forrásszöveg szerzőjének intencióit figyelembe veszi, sőt, saját intencióit is ehhez igazítja; az adódó különbségek pedig a forrás- és célnyelv közötti különbségekből származnak. ${ }^{255}$

\subsubsection{A nyugatosok}

Radó könyvéről 1910-ben Ignotus írt recenziót. Az ő felfogásában a műfordítás kritériumait, jellemzőit meghatározni, pontokba szedni lehetetlenség, mert a "művészet titkai megtanulhatatlanok." 256 Ignotus abból indult ki, hogy a forrás- és a célnyelvi szöveg közötti viszony mellérendelö, és a célnyelvi szöveget éppúgy a célnyelvi kultúra részének tekintette, mint bármely más, eleve azon a nyelven született szöveget. Meglátásában a fordítás éppolyan mértékben alkotás, produktum, mint amennyire annak tekinthető egy vers vagy prózai mü. A jó fordítás egyenlő egy jó (új) múvészi szöveggel: mindkettőben az alkotó tehetsége mutatkozik meg: „Fordítás tehát nincs, csak költő van és lehet, akinek egyszer ez a megcsinálni valója, egyszer más; egyszer az, hogy megírja, mennyire szerelmes, másszor az, hogy megírjon a maga nyelvén egy verset, amit más nyelven olvasott. (...) A fordításban, akár akarja, akár nem, a fordító egyénisége fejeződik ki, nem pedig azé, akit lefordít." ${ }^{257}$

A Nyugat első nemzedékének fordításról vallott felfogása fordítói elöszókban, valamint Babits és Kosztolányi műhelytanulmányaiban és esszéiben követhetôn nyomon. Kazinczy elve, miszerint a fordítás célja az irodalmi ízlés csiszolása és fejlettebb tudatformák kialakítása, Babits és Kosztolányi írásaiban bukkant fel újra. Mindketten újító szerepet szántak a fordításnak: „csiszoltuk a nyelvünket idegen verseken, hogy saját bonyolult érzéseink kifejezésére gazdag és könnyed, tartalmas és nemes nyelvet kapjunk". ${ }^{258}$ Vagy: „A múfordítás új csatornákba kényszeríti egy nép gondolkodását, mely eddig csak nyelvének megszokott folyosóin tudott haladni, mást alig sejthetett." ${ }^{259}$ A nyugatosok fordításról vallott felfogásának a 18. század végéhez való kötődését Hatvany Lajos konkrétan is megfogalmazta, amikor arról írt, hogy az új irodalmi modelleket más többrendszerekben kell keresniük: „otthon semmi keresni való, át kell néznünk a szomszédba."260

\footnotetext{
${ }^{255}$ Vö. JÓZAN 2003: 414.

${ }^{256}$ IGNOTUS 1910: 471.

${ }^{257}$ Uo. 472.

${ }^{258}$ KOSZTOLÁNYI 1914: 5.

${ }^{259}$ BABITS 1912: 663.

${ }^{260}$ HATVANY 1908: 569.
} 
Ezzel és Ignotus Radó-bírálatával részben a 19. század végének müfordítói felfogásával szemben foglaltak állást. A két elv közötti különbség abban a hangsúlyeltolódásban keresendő, mely a forrásnyelvi és célnyelvi olvasó befogadás-ekvivalenciájától a célnyelvi olvasó felé tolódik. Például Kosztolányi felfogásában. Az ő „ambíciója” az volt, hogy „szép magyar verset” adjon. Babits és Kosztolányi között elég nagy volt a felfogásbeli különbség. Szegedy-Maszák Mihály ezt a különbséget a fordítás mibenlétéről alkotott kétféle előfeltevésükben látja. Babits előfeltevésében a kultúrák nagyvonalakban hasonlítanak egymáshoz. Ô a forrásnyelvből kiindulva értelmezte a célnyelvi szöveget: „,mennél hívebbek maradunk a szöveghez formailag, annál több kilátásunk van arra, hogy tartalmilag is hívek maradhatunk, legalább ahhoz, ami a tartalomban lényeg." ${ }^{261} \mathrm{~A}$ „Milyen lenne magyarul egy ilyen vers?" babitsi kérdésfelvetésben, ahol az ilyen az idegen nyelvü mü magyarul megszólaló szövegére vonatkozik, ugyancsak ez az elgondolás érhető tetten. Kosztolányi figyelme ezzel szemben a két kultúra viszonyára, párbeszédére irányult.. ${ }^{262}$ Fordításról vallott felfogása előremutat a 20. század végi, a fordítást kulturális transzferként kezelő megközelítésre.

A Nyugat későbbi nemzedéke részben hű maradt Babits és Kosztolányi felfogásához, ugyanakkor visszanyúlt a Radó által megfogalmazott elvekhez is. Szabó Lőrinc fordításköteteinek előszavában egyfelől a fordítás alkotó jellegét emelte ki: „müfordítók csak költők lehetnek, munkájukhoz ihlet és teremtő képzelet és különleges nyelvi erő kell", ${ }^{263}$ másfelől a forrás- és célnyelvi szöveg ekvivalenciáját hangsúlyozta: „A kitűnő müfordítás előfeltétele tehát kitűnő költészet, $\mathrm{s}$ a benne megoldott nyelvi feladatok egyenértéküek (...) az eredeti alkotás hasonló eredményeivel."264

\subsubsection{A 20. század 50-es éveitől a 70-es évek végéig}

Az 50-es években olyan fordítói elv körvonalazódott, mely explicite is a nyugatosokkal szemben tételezte önmagát. Kardos László „fordítói realizmusnak"265 nevezi azt a törekvést, mely célul a történelmi-tartalmiszellemi interpretációhűség megvalósítását tűzte ki, mely cél a marxizmus történelemszemléletének, valamint a tartalom és forma dialektikus egységét hangsúlyozó esztétikájának alapelveiből következett. ${ }^{266} \mathrm{E}$ fordítói elv szélsőséges megnyilvánulása olvasható ki a fiatal Kardos László 1958-ban

\footnotetext{
${ }^{261}$ BABITS 1978: 278.

${ }^{262}$ Lásd SZEGEDY-MASZÁK 1998: 66-92.

263 SZABÓ 1941: 5.

${ }^{264}$ Uő 1950: 14. [kiemelés tőlem, V. P. I.]

${ }^{265}$ vö.: KARDOS 1973: 70-124.

${ }^{266}$ Vö. FALUS 1962: 209.
} 
megjelent cikkéből. ${ }^{267}$ A 70 -es években mérsékeltebben ugyan, de a nyugatosokkal való szembenállás továbbra is megjelent a fordítással foglalkozó tanulmányokban, cikkekben. Mindez úgy, hogy a fordításról vallott felfogás történetiségét - különösen a tartalmi és formai hüség kérdését - fejlödési folyamatként írta le: „A müfordítás elméletének egyik sokat vitatott pontja a formahűség kérdése. A tartalmi hűség kérdésében az elmélet sohasem adta fel igényeit, az alaki hűség dolgában sűrűn ingadozik. A magyar gyakorlat az eredeti formának mentül teljesebb átmentése felé fejlödött és fejlödik..." 268

Kardos Lászlóhoz hasonlóan az ugyancsak pályakezdő Kenyeres Zoltán is fejlődési folyamatként láttatta a fordításról való gondolkodás alakulását a magyar irodalomban. A Nyugat nemzedékét előkészítőnek tartja, olyan generációnak, amely "megteremtette” az alapot, jelen esetben egy magas szintü irodalmi nyelvet mint eszközt: „A modern fordításirodalom (...) első hullámának az volt a jellegzetessége, hogy a költő elsősorban önmagának fordított; arra törekedett, hogy költészetének látóhatárát növelje, eszközeit csiszolja, és az egyéniségét fejlessze a világlíra áramába kapcsolva. A nemzeti művelődés azáltal gazdagodott, hogy e fordító-költők korszerűbbé tették a nemzeti költészet nyelvét, s magukhoz - vagyis tulajdonképp a nemzeti művelődés igényeihez - hasonították a világirodalom

${ }^{267}$ „A magyar múfordítók a század első évtizedében jól megtanulták a jelzőkben való pazar duslakodást, de az új feladatok ilyesmit nem igényeltek. Az új versek nem sok jelzőt kívántak, hanem inkább azt az egyetlent, amelyet az eredeti vers költője használt, azt az egyetlent - de azt mentül hívebben. Múfordítóink jól megtanulták a művészi homály gyöngéd effektusait, de az új költészet nem homályt, hanem világosságot kért tőlük. Megtanulták a szöveg neuraszténiásan érzékeny remegését, a tónus vibráló és foszforeszkáló nyugtalanságát, de az új vers egészen más kvalitásokat igényelt: higgadt erőt, biztos hangvételt, tiszta vonalvezetést. Megtanulták a melankólia gyöngéd borulatait, az enervált, fáradt ritmusokat, a lemondás fájó és puha dallamait, de most sokkal inkább a szenvedély, a bizalom, a férfias elszánás zenéjére volt szükség. Megtanulták a gazdag művészi komplikációkat, de a történelem most egyszerüséget kért tőlük. Megtanulták, hogyan lehet az eredeti szöveget a fordító egyéniségével átitatni, a fordítást szubjektivizálni, de az új költészet mindezt kevéssé tűrte. Két technika, két stílus, két szemlélet állott itt egymással szemben." (KARDOS 1958: 1239.) vagy „1945 után, a magyar történelemnek szinte száznyolcvan fokos fordulata után a szocializmus építése új feladatokat hozott szellemi életünkben is. (...) A szocializmus építéséhez, a nép szocialista átneveléséhez nélkülözhetetlen volt a müfordítók munkája - tolmácsolniuk kellett, tolmácsolni kívánták a szocialista szellemű idegen költőket. (...) Az új költészet, amely tolmácsolásra várt, alapjában különbözött attól, amely műfordítóinknak mintegy nevelőiskolája volt s amely meghatározta technikai eszközeiket, csiszolta művészi szerszámaikat. Rá kellett jönni, hogy az új költészet merőben új technikai finomságokat, újfajta művészi szerszámokat követel. (...) A müfordító, aki megtanulta, hogy adekvát módon tolmácsolja a ködös érzések bizonytalanságát, a rejtélyesen alakuló és illanó hangulatokat, kissé zavartan állott az olyan költemények elött, amelyekben nem volt semmi ködös, semmi sem volt rejtelmes, hanem ellenkezőleg: minden szabatosnak és szilárdnak tetszett, mindent átvilágított a tiszta Értelem napja." (KARDOS 1959: 279-280)

${ }^{268}$ Uő 1973: 87. [kiemelés tőlem, V. P. I.] 
őket vonzó műveit." ${ }^{269}$ A fordítói realizmus gyakorlatilag a megmutatást tekintette célnak, a fordítás pedig eszköz volt ebben. A megmutatás pedig a tökéletes fordítás ideálja, a kettős hűség - formai és tartalmi - jegyében történt.

\subsubsection{A 80-as évektől napjainkig}

Ennek a szemléletnek konkrét felülvizsgálatára az 1980-as években került sor egy - a fordítás elméletével és gyakorlatával foglalkozó - tanulmánykötetben. ${ }^{270}$ A kötet új megvilágításba helyezte a tartalmi és formai hűség kérdését. Ferenczi Zoltán dogmatikusnak nevezte azt az eszmét, hogy „magyarra minden hűségesen lefordítható”. ${ }^{271}$ A tanulmánykötetből kiindulva a 70-es évek második felére és a 80-as évekre több nézőpont egymás mellett élése volt a jellemző. Az előző két évtized kizárólagossága, dogmatikussága helyett, amikor a fordítást egyenes vonalú fejlődésként képzelték el, ebben az időszakban megkérdőjeleződik a formai hüség, valamint a fordított művek „minőségi javulásának” kérdése. Somlyó György tanulmányában a műfordítás (gyakorlat) megközelítési módjának a hagyományát a magyar irodalomban a strukturalista szövegfelfogásból kiindulva vizsgálta, és arra a következtetésre jutott, hogy a formai és tartalmi hüség szempontja, a többé-kevésbé pontosan körvonalazott ",hüség” helytelen irányba terelheti a fordítókat. ${ }^{272}$ Bart István pedig úgy lépett túl a tartalmi és formai hűség kérdésén, hogy a „mércének" új meghatározását adta. Értelmezésében a hüség vagy a mérce kérdésében nem a két szöveg - forrás- és célnyelvi - ekvivalenciája a döntő, hanem az azonosságé. Azonosság a célnyelvi irodalom szemszögéből nézve: „a fordításnak - ennek az anyagilag, tehát nyelvileg, vagyis irodalomról lévén szó, lényegileg is új múnek - nem az eredetivel kell azonosnak lennie; ez az azonosság vagy egyenértékűség mindig is csalóka ködkép volt csupán, akárcsak a kiszabásához fabrikált »objektív « mércék. A fordításnak végzete, mi több, létének egyetlen értelme, hogy helyébe lép az eredetinek, azt képviseli a befogadó irodalom képzeteinek és tradícióinak megfelelő módon - önmagával kell tehát »azonosnak« lennie." ${ }^{273}$

\footnotetext{
${ }^{269}$ KENYERES 1974: 328.

${ }^{270}$ A kötet 1981-ben jelent meg A müfordítás ma címmel. A szerkesztők (Bart István és Rákos Sándor) már az előszóban megjegyzik, hogy a kötet anyagát képező tanulmányok évek óta vártak a megjelenésre. Ebből kiindulva az 1970-es évek második felétől datálhatjuk a szemléletváltást.

${ }^{271}$ FERENCZI 1981: 44.

272 Példaként a francia impair sorfajta trocheussal és a pair sorfajta jambussal történő fordítását említi. Vö. SOMLYÓ 1981: 102-146.

${ }^{273}$ BART 1981: 269.
} 
Bár a tanulmánykötetet nem lehet egy szálra felfüzött vagy egyetlen irodalom- és fordításelméleti elvet követő tanulmányok sorozataként leírni, szinte mindegyik tanulmányírót foglalkoztatta a fordított a müveknek és a befogadó vagy célirodalomnak a viszonya. Vagy úgy, ahogyan Bart Istvánt, amint a fentebbi idézetből is kitünik, vagy úgy, ahogyan Göncz Árpádot. Mindkettejük írásában a célirodalmi, a célnyelvi kultúrába illeszkedés az, ami a jó fordítás ismérve lehet. Ugyanakkor formai és tartalmi szempontból is meg kell felelnie a forrásnyelvi szövegnek. Egy másik többrendszer megmutatása mellett ismét feltünik az a gondolat, hogy a fordítás tulajdonképpen a célirodalom megújító törekvéseit alapozza meg: „a mű - a fordítás - (...) [feladata] végső soron nem más, mint a magyar irodalom, a nyitott és egyre változó magyar irodalom szolgálata." ${ }^{274}$ Olyasfajta szintézis ez a tanulmánykötet, mely egyaránt reflektál az elődök gondolkodásmódjára, ugyanakkor előremutat a 90-es évekre is.

Ugyanez a gondolat visszhangzik a 90-es évek fordítással foglalkozó tanulmánykötetében, a fordítás sikerét nem a forrásszöveghez való hüség határozza meg, hanem az, hogy képes-e beilleszkedni a magyar irodalmi hagyományba. ${ }^{275} \mathrm{~A}$ tanulmánykötet a korabeli magyar irodalomtudomány néhány iskolájának a fordítás kérdéséhez való közelítését vizsgálja. A hangsúlyt a fordítás folyamatában jelentkező forrás- és a célkultúra közti dialógusra helyezik, mely majd a kész szöveg és a célnyelvi olvasó közti befogadási folyamat dialógusában folytatódik.

Két - a fordításelméletekben újnak számító - fogalommal is találkozunk: a szövegközöttiség és az idézés fogalmával. Ezek bevezetése a két szöveg (forrás- és célnyelvi) viszonyának a rétegzettebb vizsgálatára készteti a fordítással foglalkozókat. Bár Józan Ildikó megjegyzi, hogy az intertextualitás meghatározásai vagy fogalomtörténeti előzményei alapján nehéz a müfordítás és az intertextualitás között valamiféle viszonyt feltételezni, a rifaterre-i intertextualitás-meghatározás közelebb hozhatja e két fogalmat egymáshoz. ${ }^{276}$ Rifaterre értelmezésében az intertextuális viszony a befogadás függvénye, a szövegközöttiség az a jelenség, amelyben az olvasó különböző művek között fennálló összefüggéseket észleli. Az ötödik Kalevala-fordító, Szente Imre éppen erre az olvasási módra hagyatkozott, amikor fordításába a magyar kultúrkörből ismert vendégszövegeket illesztett. Tette mindezt a két kultúrában meglevő analógiák alapján. A kultúrák közti dialógus gondolata és egyáltalán a „kulturalista” fordítás a nemzetközi és a magyar irányzatokra is hatást gyakorolt. A fordítások vizsgálatában még a 20. század közepén központi helyet elfoglaló nyel-

\footnotetext{
${ }^{274}$ GÖNCZ 1981: 60.

${ }^{275}$ SZEGEDY-MASZÁK 1998: 70.

${ }^{276}$ Lásd JÓZAN 1998: 133-145.
} 
vészeti megközelítés egyre inkább eszközzé vált a kultúrák fordításának vizsgálatában.

\subsection{A köznyelvứ, erdélyi Kalevala - Nagy Kálmán fordítása}

Nagy Kálmán először 1966-ban publikált részleteket készülő fordításából. Ezt követte az 1969-ben, a Téka sorozatban megjelent 6 ének Kalevala földjén címmel. A teljes szöveg először 1972-ben, Bukarestben, majd 1975ben Budapesten jelent meg Baász Imre illusztrációival.

Fordításának kritikai fogadtatását legtalálóbban a köznyelvú és az erdélyi szóval lehetne jellemezni. A következőkben azt vizsgálom, hogyan jelenik meg e kettő a fordításról szóló, arról beszámoló vagy azt elemző írásokban.

\subsubsection{A formailag hű fordítás ideálja}

Nagy Kálmán már az első fordításrészletek publikálásakor írt az újrafordítás okairól. Az újabb átültetést csakis az előzőnek „tagadhatatlan erényei figyelembevételével" vélte megvalósíthatónak. Nagy Kálmán elismerően szólt elődje munkájáról, annak értékeit nem vitatta. Újrateremtésként láttatta a Vikár-átültetést, amely „több mint fordítás”. Nagy ugyanis egy fordításban a megmutatás gesztusát tekintette elsődleges célnak. Saját szövegét nyíltan is Vikár "elavult szóhasználatával” szemben pozicionálta: „[az újrafordítást] szükségessé teszi egyrészt az, hogy a Vikár használta versformánál az eredetit jobban megközelítő, a magyartól mégsem idegen versforma használata lehetséges. Másrészt: szóhasználata, olykor nyelvi szerkesztése is bizonyos fokig elavult... azt szeretném, hogy a mai olvasó könnyebben megértse, átérezze, jobban mélyére tudjon hatolni a Kalevalának." ${ }^{277}$ A Kalevala nyelvezetét és a versformáját érintő megállapításai fordítói intencióiról árulkodnak: egy mindenki számára érthető nyelven megírt, formailag a forrásszöveghez idomuló átültetést kívánt az olvasó kezébe adni. Az újrafordítás szükségességét tehát voltaképpen a fordításról való gondolkodásban bekövetkezett változással magyarázta: a kettős hüség - formai és tartalmi - eszméjét követte, ahol a kettő nemcsak kéz a kézben jár, hanem feltételezi is egymást.

Az 1972-es teljes szöveg megjelenése előtti reagálásokból Szilágyi Domokos írását emelem ki, mivel később a magyarországi ismertetésekben és tanulmányokban is hivatkoznak rá. ${ }^{278} \mathrm{Az}$ ő írása vezette be a Korunkban

${ }^{277}$ NAGY 1971: 571.

${ }^{278}$ SZILÁGYI 1967., akik hivatkoznak rá: JÁVORSZKY 1973., VARGA 1973. 
megjelent Nagy-fordítás részleteit. Írásában arra kereste a választ, hogy miért van szükség a kanonizált, „,vikárul beszélő” Kalevala után egy újabb fordításra. Az új fordítás szükségességét ő is a fordításelméletben bekövetkezett változással magyarázta, az 1960-as években oly fontossá vált formai hűség hangsúlyozásával. Szilágyi a forrás- és célszöveg közötti ekvivalencia-elvárásból indult ki, amikor a Kalevala négyes trocheusainak formahű célnyelvi megvalósításáról írt, majd ugyanígy járt el az alliterációk tekintetében is. Ami ez utóbbit illeti, úgy vélte, hogy a célkultúra valósággal felkínálja a fordítónak az ilyesfajta megvalósítást, mivel a magyar irodalomban is van ennek hagyománya. Ezzel párhuzamosan a sorvégi rímek miatt is elmarasztalja Vikárt. Szilágyival ellenkező állásponton van Jávorszky Béla ${ }^{279}$, aki elsőként reagált az 1969-ben megjelent kötetre. Ő az egyedüli külföldi recenzens a teljes szöveg megjelenése előtti időszakban. Írását nem a híradásra vagy beszámolóra jellemző semleges, hanem bíráló hangvétel jellemzi. A Nagy-fordításon éppen a sorvégi rímek hiányát kérte számon. Véleménye szerint ugyanis ezt csak részben kompenzálhatják a jól sikerült alliterációk. A rímnélküliség a szöveg „túlszegényítését" eredményezi a Vikár-szöveggel és a finn szöveggel összehasonlítva egyaránt. Igaz, ezt a vikári „túldíszítettséggel” állította szembe.

A bukaresti megjelenés utáni első ismertetést ismét Szilágyi Domokos írta. Kitűnő érzékkel választotta ki Vikár Béla és Nagy Kálmán fordításaiból azt a részt, mely leginkább tükrözi a két fordító közötti felfogásbeli különbségeket: az archaizáló Vikár és a köznyelvűséget, érthetőséget szem előtt tartó Nagy képe bontakozik ki. Szilágyi, a tőle megszokott iróniával, miután a cikk bevezető részében ismét tételesen felsorolta Vikár fordításának támadható pontjait, az általa választott Kalevala-részletek után így foglalta össze mondanivalóját: „Akinek van szeme a látásra, lássa." ${ }^{280}$

A teljes fordítás bukaresti és budapesti megjelenése között eltelt három évben tizenegy írás, a budapesti megjelenés után pedig két ismertetés született Nagy Kálmán fordításáról. ${ }^{281} \mathrm{Az}$ ismertetések és tanulmányok szempontjából a két periódus közötti legszembetűnőbb különbség az, hogy a teljes fordítás megjelenését követően magyarországiak, finnugor irodalommal és nyelvészettel foglalkozók írtak az új fordításról.

\footnotetext{
${ }^{279}$ Jávorszky Béla költő, műfordító. Finn és észt irodalomból fordít. A Magyarországon megjelenő Suomi címú folyóirat szerkesztője volt a 80-as években.

${ }^{280}$ SZILÁGYI 1973. 2.

${ }^{281}$ A Nagy-fordításról írók: Domokos Péter az uráli népek irodalmának kutatója; Dugántsy Mária a 70-es évektől a svédországi uppsalai egyetem finnugor tanszékének oktatója; E. Fehér Pál kritikus; Nyirkos István nyelvész; Pusztay János finnugor nyelvész; Varga Domokos (1922-2002) író, müfordító, a Kalevalából is fordított részleteket; Ruffy Péter (1914-1993) riporter és közíró, Szily Ernő (1919-1980) műfordító.
} 
Jávorszky Béla a bukaresti megjelenés után is foglalkozott Nagy Kálmán fordításával. Két írása alapján megállapíthatjuk, hogy meglehetősen megváltozott a szerző müfordításról és a finn eposz poétikájáról vallott felfogása. 1970-ben még elmarasztalta Nagy Kálmánt a sorvégi rímszegénység miatt, 1973-as írásában az elmarasztaló megjegyzést egy mellékmondatba sürítette, elismerve, hogy az eredeti rímek csak véletlen összecsengések, a gondolatritmus játékai. Amellett azonban továbbra is kitartott, hogy ezeknek a véletlen összecsengéseknek a hiánya eszköztelenebbé, puritánabbá, szegényebbé is tette Nagy szövegét. Az alliterációk és ritmus tekintetében Nagy elismerten felül is múlta Vikárt, sőt, a forrásszöveghez igazítás, Jávorszky szóhasználatával élve, visszatérést jelentett, és Vikár rímgazdagságával állt szemben.

Az 1975-ös magyarországi megjelenés a Románia és Magyarország közötti könyvkiadási megállapodásnak az eredménye. A budapesti kötet elö- és utószó nélkül jelent meg, a végén a fordító özvegyének jegyzeteivel. A kötetben található egy szerző nélküli Néhány szó a fordítóról szöveg, mely biografikus adatokat tartalmaz a fordítóról: mikor és hol született, hol élt, röviden vázolja munkásságát. Az utolsó mondata akár a kötet ajánlása is lehetne: „Kalevala-fordítása minden tekintetben méltó a nagy elődök - Barna Ferdinánd és Vikár Béla - munkájához. Szövege azonban modernebb, hajlékonyabb és közelebb áll a huszadik századik emberéhez." Az azonban kötőszó kissé megzavarja az olvasót. Ha csak Barna Ferdinánd neve szerepelne, akkor ironikusnak is vélhetnénk, hiszen láttuk, hogy Barnához meglehetősen negatívan viszonyultak. Ha ezzel állítódik szembe Nagy Kálmán, akkor az egyértelműen elismerést jelent. Viszont megjelenik Vikár neve is, amivel így aztán végképp nem tudunk mit kezdeni, hiszen ha az ő pozitív fogadtatásával szemben definiálódik a Nagy Kálmáné, akkor az egyértelmúen negatív lesz.

A budapesti megjelenést követő írások fele ismertető jellegü, napilapok vagy irodalmi lapok könyvszemle és könyvújdonság rovatában jelent meg. Ezek többnyire nem is az új fordításra, hanem a Kalevalára mint finn nemzeti eposzra fektetik a hangsúlyt, megemlítve a teljes magyar fordításokat is. A recenzensek nyelvhasználata azt sugallja, hogy az 1970-es évek elején Vikár fordítása még érinthetetlen, sérthetetlen. Nagy szövegére úgy reagálnak pozitívan, hogy rögtön Vikárnak is elégtételt szolgáltatnak. Lássunk pár példát az írások nyelvhasználatára: „A ritmusban persze többnyire Vikár is pontos. (...) a kényszermegoldások csökkentése, élőbb, modernebb kifejezések alkalmazása az, amely Vikárrral szemben Nagy mellett szól, anélkül, hogy Vikár érdemeit csökkentené", 282 "Tízéves lankadatlan munka eredményeképpen új, s a nagyszerü elödhöz nem méltatlan alko-

${ }^{282}$ Uo. [kiemelés tőlem, V. P. I.] 
tás született”,283 „Nagy Kálmán fordítása nem teszi feleslegessé, árnyékba se borítja elődjének munkáját",; 284 „költőiségben Nagy Kálmán nem éri el ugyan Vikár fordításának szintjét, mégis modern, a széles olvasóközönség igényeivel számoló, természetes nyelven megszólaló, az eredetihez formailag jobban igazodó költói fordítás az övé", 285 "Nagy Kálmán az eredeti szöveghez szellemében, formájában közelebb álló múvet teremtett Vikár bravúrjánál". ${ }^{286} \mathrm{Az}$ idézetek alapján úgy tünhet, hogy ha visszafogottan is, de a Nagy-fordítást elismerő jelzők és mondatszerkezetek legalábbis rákérdeznek az előző fordítás kanonizált helyére. Ugyanakkor az is kitünik, hogy az új fordításnak a forrásszöveghez való szellemi és formai hüsége az 1970-es évek végén már nem elégíti ki a szakolvasók elvárásait.

Amiben a recenzensek is egyetértenek, az az, hogy szükség volt új átültetésre a pontosabb formai húséggel bíró és a köznyelvű magyar Kalevala hiánya miatt.

\subsubsection{Erdélyiség a nyelvhasználatban}

A Vikár-fordítással való összevetés jellemző a Nagy-fordítás egész fogadtatására. A két szöveg megszületése között majd hetven év telt el. Ez alatt az idő alatt pedig a múfordításról való gondolkodás nagyon sokat változott. A Nagy-fordításról szóló írások problematikussága nem is ebből az érzékelt változásból és elvárásokból fakad, hanem a szerzők által használt fogalmak tisztázatlanságából, valamint a fogalmak következetlen használatából. Ilyen például az erdélyiség és a modernség fogalma.

A Vikár-fordítás bírált népiessége a Nagy-fordításnak tulajdonított (erdélyi) népies nyelvhasználattal állítható párhuzamba. Bár szinte mindegyik ismertetésben és tanulmányban hivatkoztak Nagy Kálmán erdélyi nyelvhasználatára, nem támasztották alá idézetekkel álláspontjukat, hanem a fordító erdélyi származásával már bizonyítottnak vélték azt. Ugyanakkor mindannyian kiemelendőnek és a korabeli fordítói gyakorlatnak megfelelőnek tartották a fordítás köznyelvűségét. Jávorszky például a "túlszegényítést" hozta összefüggésbe a fordítás modernségével, mások pedig magát a köznyelvűséget azonosították az általuk modernnek nevezett nyelvhasználattal. Ez pedig oda vezetett, hogy éppen a nyelvhasználat vizsgálatakor értelmetlen túlzásokba és önellentmondásba keveredtek akkor, amikor az erdélyit és a modernt próbálták egymás mellé állítani és egymással összebékíteni. Lássunk erre is pár példát: „„[Nagy Kálmán] nem

${ }^{283}$ PUSZTAY 1973: 5. [kiemelés tőlem, V. P. I.]

${ }^{284}$ LAKATOS 1974: 10. [kiemelés tőlem, V. P. I.]

${ }^{285}$ NYIRKOS 1973: 75. [kiemelés tőlem, V. P. I.]

${ }^{286}$ DOMOKOS 1973: 1093. [kiemelés tőlem, V. P. I.] 
alkalmaz - Vikárral ellentétben - maga által kitalált szavakat, kevés benne a nyelvjárási szó is, tehát minden nehézség nélkül érthető. Mindemellett gyönyörü, hátborzongatóan nemes csengésü magyar nyelven szólal meg a Kalevala, úgy, ahogy csak székelyek tudnak magyarul szólni”287; „Vikár 2300 (sic!) során át cseng és bong (vagy mondjuk: muzsikál), az erdélyi költő a nyelv barbárabb, mélyebb rétegeit tárja fel." ${ }^{288}$

A két fordítás közötti különbségek hangsúlyozása mellett a hasonlóság is fel-felbukkan egyes írásokban. Az egyik legjellemzőbb, a Kosztolányi-esszéből oly sokszor idézett Paasonen-kijelentés kiterjesztése az újabb átültetésre - a 70-es és 80-as évekre oly jellemző módon - anélkül, hogy a kijelentés forrására utalás történne: „Ha Vikár fordításásáról azt mondták, hogy az alapján rekonstruálni lehetne a Kalevalát, ez a megállapítás legalább ilyen érvénnyel áll Nagy Kálmán fordítására is. Nagy Kálmán szövege szinte szó szerint megegyezik az eredetivel." 289

Egyetlen olyan tanulmány született, melyben a Nagy-szöveggel szembeni elfogultsággal találkozhatunk, mégpedig Gáspár Sándor tollából.

\subsubsection{A legjobb magyar Kalevala? - Gáspár Sándor tanulmánya}

Gáspár Sándor tanulmánya a Korunk Szemle rovatában jelent meg 1977-ben. ${ }^{290}$ Ebben a rovatban többnyire recenziók láttak napvilágot, de Gáspár szövege tanulmánynak is nevezhető. A múfaji besorolás azért bizonytalan kissé, mert befejező mondatai az esszé felé viszik el a szöveget: „De a kecske és a káposzta meséjéből faragnak elvet azok, akik felvetik és elodázzák (vagy elhallgatják) a rangsorolást. Igenis tudnunk kell, hogy melyik fordítás felel meg leginkább igényeinknek" ${ }^{291}$ Annál is meglepőbb ez a befejezés, mivel a tanulmányban végig rendkívül logikusan, szakszerűen járja körül általában a fordítás, majd konkrétan a Kalevala-fordítások felvetette problémákat. Mielőtt azonban ezekre rátérnénk, meg kell jegyeznünk, hogy a romániai Gáspár Sándor nem Kalevala-kutató, nem finnugrista, a fordításelméletben is ismeretlen a neve. Azonban azt Fehérvári Győző is elismeri a Kalevaláról és Kalevipoegről írott munkájában, hogy Gáspár tanulmánya kiemelkedik a Kalevala-fordításokat összehasonlító tanulmányok közül. Kifogásokat ő is az utolsó mondattal szemben talál, csak éppen más megfontolásból: azzal nem ért egyet, hogy el kellene dönteni, melyik fordítás a legsikerültebb. Részben egyet tudunk

\footnotetext{
${ }^{287}$ PUSZTAY 1973: 5.

${ }^{288}$ LAKATOS 1974: 10.

${ }^{289}$ PUSZTAY 1973: 5.

${ }^{290}$ Ugyanebben a számban a Mai finn líra is bemutatkozik Jávorszky Béla bevezetőjével és fordításában: Kari Aronpuro, Pentti Saarikoski, Tuomas Anhava és Paavo Haavikko versei.

${ }^{291}$ GÁSPÁR 1977: 658.
} 
érteni Fehérvárival, de ha alaposabban megvizsgáljuk a tanulmányt és a benne vázolt fordításelméleti elveket, (rész)következtetéseinek jellegét és az egyes fordításokról írt véleményét, nyilvánvalóvá válik, hogy Gáspár azt az 1950-1970-es évek közötti paradigmát képviselte, melyet a preskriptivitás és az „,analitikus fordítás"292 eszménye jellemzett.

A tanulmány szóhasználata sokszor arra enged következtetni, hogy a szerző - amint már említettük - elfogultsággal közeledett Nagy Kálmán fordítása felé. A Vikár-teremtette nyelvet erőltetettnek nevezte és a forrásszövegtől a Nagyénál távolabb állónak. Ezzel állította szembe Nagy puritánabb, egyszerú nyelvezetét, amelyek a tartalmi hüség megkívánta követelményeknek is eleget tesznek: „[Nagy Kálmán szavai] pontosak, mintha a súlyos fenyoók országában faragták volna óket évszázadokon át." ${ }^{293}$ A két fordítás szembeállítása itt egyértelműen Nagy Kálmán javára dől el. A bevezető részben Gáspár is mindenekelőtt a Vikár-fordítást övező tekintélytisztelet jogosságát kérdőjelezte meg és azt, hogy a Kalevala-fordításokról írók akaratlanul is rangsorolnak. A Kalevala-átültetésekhez az irodalmi gondolkodásban bekövetkezett változás felől közelített, a finn eposz különböző tolmácsolásait irodalmi korszakok és szemléletbeli különbségekre vezette vissza. A forrás- és célnyelvi szövegekből különböző szempontok figyelembe vételével válogatott, igyekezett megtalálni a szempontjának legmegfelelőbb részeket. Formai és tartalmi vonatkozásokat is vizsgált, majd levonta következtetéseit, mely szerint az első két Kalevala-fordító külső eszközökkel próbálták áthidalni azt a távolságot, amely a művet az olvasótól elválasztja. Mindkettejüket azért bírálta, mert a megmutatást, az idegennel való megismertetést, az eposz verstani sajátosságait a magyar olvasó ízléséhez igazították. Ezzel szembeállítva, a megmutatást középpontba helyező Nagy Kálmán valóban „kalevalai” szöveget hozott létre. $\mathrm{S}$ bár elismerte, hogy Nagy átültetése sem tökéletes, két dolgot kiemelten jobbnak tartott a többi fordító megoldásánál: a nép szó használatát és a formahűségre törekvést, mely egyszerre bravúros és forráskultúra-specifikus.

\subsubsection{A fordító erdélyisége}

A budapesti kiadás Néhány szó a fordítóról ajánló szövege úgy tünik, arra predesztinálta a fordítás megjelenésére reagáló ismertetések és recenziók szerzőit, hogy magával a fordító személyével a megszokottnál is többet foglalkozzanak.

\footnotetext{
${ }^{292}$ Kenyeres Zoltán kifejezése.

${ }^{293}$ Uo. [kiemelés tőlem, V. P. I.]
} 
A már említett 1970-es Jávorszky-ismertetés befejező két kérdő mondata is közvetlen utalás a fordító személyére: „a könyv olvastán támad az embernek két gondolata. Az egyik: ki ismeri közülünk (az olvasók közül) Nagy Kálmánt? Azt hiszem, itthon, személyes ismerősein, barátain kívül, senki. A másik: melyik hazai kiadónk merné valamely fiatal fordító újraköltésében közrebocsátani a Kalevalát?"294 E kérdések jogossága két ok miatt is megkérdőjelezhető. Kissé erőltetett az utalás a fordító-olvasó viszonyára, különösen, ha arra gondolunk, hogy egy átlagolvasó egy fordított müvet tudatosan sohasem olvas fordításként. A fordító személye legtöbbször háttérben marad. A másik ok az „itthon” és a „hazai kiadó” által implikált máshol differenciáltsága, mely negatív töltetet kap. Vagyis a fogadtatásban az erdélyiség nemcsak mint a nyelvhasználat jellemzője jelenik meg, hanem konkrét földrajzi értelemben is: nem magyarországi.

Pusztay János és Ruffy Péter írása már nem is a fordításról szól, hanem - az erdélyi származást hangsúlyozva - a fordítóról. Ebben valószínűleg közrejátszott a fordító halála és Románia aktuális politikai helyzete is. Erre utaltak is a szerzők, amikor Nagy Kálmán életpályáját mutatták be. Ruffy az életrajzi adatok felsorolása után az utolsó mondatokban a fordítót tragikus kalevalai hősként állította az olvasók elé, akit a (politikai) körülmények halálba kényszerítettek. Olyan Nagy-képet tárt az olvasó elé, mely maga is kalevalai: a fiatal erdélyi magyartanárról írt, akinek élete értelme a Kalevala lefordítása volt, és akinek halálát egy "gonosz Louhi” okozta, elrejtve előle, ahogyan az eposzban is kalevala népe elől, a napot. ${ }^{295}$

Ami az ilyen típusú könyvismertetések reklámértékét illeti, az olvasók érdeklődését minden bizonnyal felkeltették. Különösen az utóbbi szöveg, mely metaforákra és szimbólumokra épít. Louhi, a Kalevala gonosza behelyettesíthető volt a kommunista rendszerrel és a román politikai elit magyar kisebbséget elnyomó törekvéseivel egyaránt.

A fordító személye azonban nemcsak Magyarországon, hanem Romániában is szorosan kötődött az új fordítás fogadtatásához, azzal a különbséggel, hogy az erdélyi származás nem vált hangsúlyossá. ${ }^{296} \mathrm{~A}$ fordító halálának második évfordulóján az Igaz Szó egyik 1973-as száma egy öszszeállítással emlékezett meg a fordításról és szerzőjéről Új magyar Kalevala címmel. Varga Domokos tanulmánya mellett, melyet ugyanakkor a magyarországi Kortárs folyóirat is publikált, Nagy Kálmán egykori tanára Nagy Pál és barátja, írótársa - Pusztai János emlékezett a fordítóra. Nagy Pál megpróbált valamiféle folytonosságot keresni a diák és a fordító Nagy

\footnotetext{
${ }^{294}$ JÁVORSZKY 1970: 932.

${ }^{295}$ RUFFY 1975.

${ }^{296}$ Az egyetlen kivétel Dánielisz Endre, aki írása címében A mi Kalevalánk közvetlenül utal a fordító származására, a fordítás létrejöttének helyére. A mi úgy is értelmezhető, mint a romániai/erdélyi magyar közösség.
} 
Kálmán között. Pusztai Jánosnak Gálfalvi Györgyhöz, a folyóirat szerkesztőjéhez címzett levele sokkal személyesebb és - talán mondhatjuk azt is - politikusabb Nagy Pál írásánál. Konkrétan ugyan nem mondta ki, de sejtette, hogy a fordító halálának fó oka az aktuális politikai helyzet tarthatatlansága volt. ${ }^{297}$

A fordító halálának harmincadik évfordulóján, 2001-ben egy finn kutató emlékezett meg a romániai Helikon hasábjain Nagy Kálmánról és Kalevala-fordításáról. ${ }^{298} \mathrm{~N}$. Sebestyén Irén és Irmeli Kniivilä levelei, valamint a fordított szöveg Vikár-fordításával való összevetése alapján Viljo Tervonen arra a következtetésre jutott, amire már az 1970-es években is a fordítást vizsgálók, hogy Nagy fordítása nem olyan díszes nyelvezetű, mint Vikáré, hanem puritánabb, ezzel azonban sikerült a forrásnyelvi szöveghez és a kortárs olvasó nyelvezetéhez is közelebb álló átültetést létrehoznia. A forrás- és célolvasó közötti ekvivalenciát úgy éri el a fordító, hogy stratégiájában nem abszolutizálja sem az alliterációkat, sem pedig a rímeket. A befejezésben pedig a többi fordítás pozitívumára hívta fel a figyelmet. Tervonen véleménye szerint az egymástól különböző magyar Kalevalák formai megoldásaikkal a forrásszövegnek is nagy szolgálatot tesznek, hiszen folyamatosan gazdagítják a magyar olvasó Kalevaláról alkotott képét.

Nagy Kálmán fordításának budapesti kiadását nem követte újabb sem Romániában, sem Magyarországon. Romániában, az alternatív magyar irodalom tankönyvek megjelenéséig a VIII. osztály számára készült tankönyvben találkozhattunk ezzel a fordítással. 2009-ben pedig az Erdélyi Híradó gondozásában jelent meg Kolozsváron A csodaszampó címmel egy válogatás a fordításból. ${ }^{299}$

A fordító neve a két legújabb fordítás fogadtatásában merült fel, immár az öt teljes magyar Kalevala között keresik Nagy Kálmán átültetésének helyét.

297, ,...) halála óta szakadatlanul rágondolok, szakadatlanul előttem van, látom az utcán, látom közeledni, vaskapunkon befordulni, hallom kopogtatni, beszélni, látom ugrani a feneketlen mélységbe, himbálózni a levegőben, hallom ordítani, ordítani utoljára a visszaszerezhetetlen biztonságért, hallom belepuffanását a semmibe, és mindez, mint szakadozott, vakítóan fehér függöny, eltakarja előlem őt, a tudós-művészt, a szerénységével, szótlanságával, a dolgok iránti (most már tudom, látszólagos) közönyével engem számtalanszor borzoló, szikár, magas, enyhén fekete alakot; ki kell mondanom, sokszor dühös voltam rá, nem tudtam, hogy távozóban, »szökésben« van." PUSZTAI 1973: 367.

298 TERVONEN 2001: 16-17.

${ }^{299}$ A kiadvány a romániai Jóbarát című folyóiratban 1972-ben megjelent, prózában fordított szövegeit gyűjtötte össze. A kötetet Szervátiusz Tibor illusztrálta. Az illusztrációkat a jövőben érdemes lenne a finnugor háló szempontja felől megvizsgálni. 


\subsection{A „vikárul beszélő" és a köznyelvű Kalevala között - Rácz István fordítása}

Rácz István fordítása negyedik a magyar Kalevalák sorában, Barna Ferdinánd, Vikár Béla és Nagy Kálmán fordítását követi. Hogy a címben mégis a között szerepel, az arra utal, hogy a Rácz-fordítás fogadtatásában a két közvetlen fordítóelőd - Vikár és Nagy - átültetésének recepciójában megnyilvánuló hatások ötvöződtek. Gondolok itt két szempontra: a költőiségre és a köznyelvűségre.

A teljes fordítás először 1976-ban Helsinkiben jelent meg 200 példányban a fordító saját költségén, majd 1980-ban az Európa kiadó gondozásában. Rácz a finn irodalom fordítójaként ${ }^{300}$ már ismert volt, természetes volt Kalevala-fordításának gyors magyarországi kiadatása.

\subsubsection{A fordítás költőisége}

Rácz István, akárcsak Vikár Béla, a Kullervo-epizód magyarra ültetésével kezdett a Kalevala lefordításába. A teljes fordítás helsinki megjelenése után a földrajzi távolság ellenére a megjelenés híre és néhány példány Magyarországra is eljutott a kiadásból. Ennek nyomán több ismertetés ${ }^{301}$ napvilágot látott. Szinte mindegyikre jellemző, hogy sürgetik a magyarországi megjelentetést és a legújabb fordítást az azt megelőző két magyar Kalevalával vetik össze. Rácz István magyarítását a két előző fordítás szintéziseként fogják fel: formai megoldásai, nyelvezete révén az azt megelőző két fordítás között helyezkedik el. Formai és tartalmi hűség tekintetében Nagy munkájához áll közel, s mindezt úgy valósítja meg, hogy Vikár átültetésével költőiségben is felveszi a versenyt. A költőiség hangsúlyozásával a Vikár-fordításhoz kerül közelebb Rácz István szövege. Hiszen - amint azt a Nagy-fordítás fogadtatását vizsgáló fejezetben is láttuk - Nagy szövegét éppen költőiségében marasztalták el. A negyedik Kalevala-fordító bevallottan az alliterációkra helyezi a hangsúlyt, még akkor is, ha ez a fordításában a tartalmi hüség rovására is történik. Meglátásában ez azt jelentette, hogy a szó szerinti és a költői hűség között kellett választania. Ez utóbbit választotta, feláldozva egy jelzőt vagy igét, főnevet, ha az biztosította az alliteráló megoldást. ${ }^{302}$

\footnotetext{
${ }^{300}$ 1955-ben jelent meg Aleksis Kivi: A hét testvér című regényének fordítása, valamint a Kanteletárból is fordított.

${ }^{301}$ GOMBÁR 1977., JÁVORSZKY 1977., KOCZOGH 1977., SZOPORI NAGY 1978., TÜSKÉS 1977.

${ }^{302}$ RÁCZ 1976: 405.
} 
A recenzensek közül nem mindenki értett egyet Rácz István stratégiájával. Fordításának legfőbb bírálója Jávorszky Béla, aki úgy vélte, ez már „végletes értelmezése" az alliterációk fontosságának és egyáltalán nem szerencsés a szöveg egészére nézve, mivel az alliterációgazdagság a finn eposz többi formai sajátosságait szorítja háttérbe, a gondolatritmust és a sorvégek primitív összecsengését, melyet ragrímeknek nevez. Jávorszky már a Nagy-fordításból is hiányolta a végrímeket. Éppen emiatt kapta az a fordítás a "túlszegényített" jelzőt, szemben Vikár "túldíszített" Kalevalájával. Rácz eposzfordítása, Jávorszky meglátásában, költőiségben meg sem közelíti a Vikárét, sőt, ha sorrendbe kellene tenni őket, akkor Nagy átültetése mögé kerül. ${ }^{303}$

Vele szemben a többi ismertetés éppen a fordítás alliterációgazdagságát emelte ki. Úgy vélték, hogy éppen ettől lesz ez a fordítás a Nagy Kálmánénál „költőibb”. Ugyanakkor a tartalmi hűtlenség is ezzel kompenzálható: „,a tartalmi hüség ellen nem vét: csupán annyit enged meg magának, hogy szükség esetén az alliterálás kedvéért egy-egy növény- vagy állatnevet megváltoztasson, illetve egy kicsit szabadabban válogasson a szinonimák között. Vagyis a költői pontosság érdekében enged az etnográfusi pontosságból”. ${ }^{304}$ Vagy "híven követi az alliterációkat, s bár így a fordítás szabadabbnak tünik, jobban megközelíti a lényeget." ${ }^{305}$

\subsubsection{A vikári örökség hozadéka}

A fordítás budapesti megjelenése után született ismertetések nem hoztak új szempontot az előző periódushoz viszonyítva. Amiben mégis más a fogadtatásnak ez a periódusa, hogy a főszerep sokkal inkább a négy teljes magyar Kalevalát összehasonlító tanulmányoké, ${ }^{306}$ melyek a költőiség mellett a szöveg népies vonásaira is felhívták a figyelmet. Költőiség és népiség kulcsszavak már a Vikár-fogadtatásban is meghatározóak voltak. A finnugor irodalommal és nyelvészettel foglalkozó tanulmányírók ezenkívül a teljes fordítások pozitívumaira és hiányosságaira hívták fel a figyelmet. A Nagy-fordítás fogadtatásában tapasztalt - a Vikár-fordítás bírálatától tartózkodó - magatartást felváltotta egy nyitottabb és objektívebb hozzáállás. Továbbra is Vikár Béla fordítása volt az összevetések alapja. Értékeit egyik tanulmányíró sem vitatta. Ugyanakkor mindannyian kiemelték azokat a hiányosságokat, melyek az újrafordítást szükségessé tették. Írják mindezt

\footnotetext{
${ }^{303}$ JÁVORSZKY 1977.

${ }^{304}$ SZOPORI NAGY 1977: 446 [kiemelés az eredetiben] - Érdekes, hogy éppen az etnográfusi hűséget állítja szembe a költői hüséggel. Ezzel a szóhasználattal a Vikár-fordítás fogadtatástörténetének kulcsszavaira utal vissza.

${ }^{305}$ KOCZOGH 1977: 8.

${ }^{306}$ PUSZTAY 1982., DOMOKOS 1983. és 1985., PÉLI 1985., VAJDA 1985.
} 
a fordítások keletkezési idejének fordítási elveivel összhangban: a Vikárszöveg nyelvileg és a fordítói ízlés tekintetében is némileg archaikussá vált, ezért volt szükség új magyar Kalevalára. ${ }^{307} \mathrm{Az}$ írások összevetéseinek kiindulópontja - nem meglepó módon - az átültetések formai sajátosságainak a vizsgálata volt. Az újabb Kalevalák helyét a Vikár-fordításhoz viszonyítva keresték. Az „erdélyi” Kalevala megjelenésével elindult folyamat az 1970-es évek végére érte el tetőpontját: az objektívebb hozzáállás mellett végkövetkeztetéseikben a tanulmányírók közvetlenül vagy közvetetten rangsorolnak. A rangsorolás alapján pedig úgy tünik, hogy Rácz István fordítása az, amely átveheti a kanonizált, klasszikussá vált Vikár-fordítás helyét a magyar irodalmi gondolkodásban. Pusztay János és Domokos Péter is „egyre hübb fordításokban megszólaló eposz"-ra ${ }^{308}$ való utalással Rácz átültetése mellett foglal állást.

Az ismertetések közül Péli Árpádét emelem még ki. Ő ugyanis abból indult ki, hogy bár a fordításról való gondolkodásban és a szakolvasói elvárásokban történtek változások, az olvasói igények vajmi keveset változtak fél évszázad során, különösen a rímes verselés tekintetében. Ezt továbbgondolva vélte úgy, hogy Rácz István fordításának sikere éppen ezeknek az igényeknek való megfelelésben gyökerezik. Rácz ugyanis egyszerre tudott költői és a Vikárénál köznyelvibb (a Nagy Kálmánét megközelítő) eposzt teremteni. ${ }^{309}$ Bár ő is rangsorolt, az ő véleménye tükrözte leginkább az 1980-as években a magyar irodalmi gondolkodásban egymás mellett élő fordításelméleti paradigmák elveit: a célkultúra elvárásaihoz és hagyományához igazodó átültetés helytállóságát.

A Nagy-szöveg fogadtatásában már utaltunk Gáspár Sándor tanulmányára. Az ő rangsorolásában a Nagy-fordítás került az első helyre. A legtöbb kritikát a tanulmányban Rácz István kapta, de jól sikerült megoldásaira is felhívta a figyelmet. Gáspár a preskriptív elvekhez hűen, a tanulmány folyamán többször is rámutatott egy-egy melléknév vagy költői kép oda nem illőségére. A Rácz-fordítás legnagyobb hibájának ő is az alliteráló kényszert tartotta: „a szókincs, a mondatszerkezet, a képek, mindez a betürímek nyersanyaga csupán". ${ }^{310}$ Ugyanakkor kiemelte a szöveg népies vonásait. A fordítás sikerét is abban látta, hogy Rácz megvalósította a népies jelleg visszaadását.

\footnotetext{
${ }^{307}$ PUSZTAY 1982: 29.

${ }^{308}$ DOMOKOS 1983: 258.

${ }^{309}$ PÉLI 1985: 5.

${ }^{310}$ GÁSPÁR 1977: 658.
} 


\subsubsection{Két kiadás - két koncepció?}

Az előbbiekben már láttuk hogyan kapcsolódik össze Vikár Béla és Rácz István fordítása a fogadtatásban. A Nagy Kálmán-i szöveghez a köznyelvűség szempontján keresztül kapcsolható a negyedik magyar Kalevala. Úgy vélem azonban, hogy nem ez az egyedüli kapcsolódási pont a két szöveg között. A budapesti, 1980-ban megjelent kiadás koncepciója ugyanis eltér az első, helsinki kiadástól. Vizsgáljuk meg tehát a két kiadást és a felvállalt fordítói stratégiákat.

Az újrafordítás oka közvetve az addigiakkal való elégedetlenség volt. Rácz a megkülönböztethetőség érdekében a közvetlen fordító-elődhöz viszonyult kritikusan: „megjelent Nagy Kálmán Kalevalája is, amit igen szépnek találtam, de valahogyan mégsem kielégítónek". ${ }^{311}$ Emellett pedig a fordítóban ott munkált az anyanyelvi kompetenciájában való kételkedésen keresztül a bizonyítási vágy, hogy tud még magyarul: majd két évtizedes külföldi tartózkodás után így lesz a fordítás az anyanyelv próbája. Finnországi tartózkodását ugyanakkor úgy láttatta pozitívumként, hogy saját forrásnyelvi kompetenciáját helyezte előtérbe. Öntudatos fordítóként a budapesti kiadás Eligazítójában arról nyilatkozott, hogy ismeri a finn irodalmi és köznapi nyelv ezer árnyalatát. A Finnországban élő Ráczot fotósként foglalkoztatta többek között a Finn Nemzeti Múzeum. Több albumot is összeállított a finnek régi művészetéről és népművészetéről. Ez pedig még inkább feljogosítja arra, hogy a finn népi eposzt magyarra átültesse.

Mindkét kiadás utószava az Eligazító címet viseli, a budapesti kiadásban található utószó tulajdonképpen az előzőnek a bővített változata.

Akár csodálkozásra adhat okot az első kiadás Eligazítójának felütése, amikor a Kalevaláról mint idegen, ismeretlen világról beszélt, majd röviden vázolta az eposz tartalmát, bemutatta a szereplőket. Tette mindezt a helyesebb, pontosabb megértés érdekében. Valószínúleg inkább retorikai fordulatként illesztette utószavába, mintegy előkészítve az olvasót az ezt követô szó- és névmagyarázatokra. A budapesti kiadásban ezt még megelőzte egy rövid beszámoló, melyet a Kalevala keletkezéséről és Lönnrot szerkesztői szerepéről írt. Ugyanez a kiadás valamivel több név- és szómagyarázatot tartalmazott.

A két kiadás közti legfőbb különbség a fordító által végzett szövegjavításokon kívül az illusztrációkban rejlik. Rácz István fotómúvészként nemcsak Finnországban volt ismert, hanem Magyarországon is. Ezt kamatoztatva, az Európa kiadó a fordító saját maga készítette, a „kalevalai” kor

\footnotetext{
${ }^{311}$ Rácz István beszámolója a vele készült interjúban. 1985: 55.
} 
művészi alkotásairól készült felvételekkel illusztrálta a kötetet. ${ }^{312}$ Rácz István nem szerénykedik, amikor a kiadás egyedülállóságáról a következőképpen ír: „a Kalevala Finnországban s külföldön is többnyire gazdagon illusztrálva jelent meg, de ezek az illusztrációk mindeddig korunk múvészeinek, grafikusainak a munkái voltak. Eleddig senkinek sem jutott eszébe, hogy a runók elbűvölő mesevilágát a hajdani »kalevalai« kor művészi alkotásinak kíséretében mutassa be. Ebből a szempontból tekintve az a »kincses Kalevala«, amelyet most kap kezébe a magyar olvasó, első és mindmáig egyetlen a maga nemében". ${ }^{313} \mathrm{Az}$ idézet azt hangsúlyozza, hogy a képek csupán az előző fordításoktól való megkülönböztethetőséget szolgálják. Azt gondolom azonban, hogy nemcsak egy illusztrált kiadásról van szó, hanem a képek egy - az elóző kiadástól eltérő - koncepcióról árulkodnak. Ha az Eligazítóban rácsodálkoztunk az idegen és ismeretlen világ említésére, a képek felől olvasva már azt is láthatjuk, hogy az illusztrációknak csak ezzel a megjegyzéssel van relevanciájuk. A fotók pár kivétellel a feltételezett kalevalai kor használati- és dísztárgyait ábrázolják, ezeket Rácz a Kalevala kovácsa, „Ilmarinen remekműveinek” nevezi. A képek a szöveghez így és

\footnotetext{
${ }^{312}$ A képek jegyzéke: kantele Korpiselkäből, kendő Impilahtiból; fa és madár egy Saarijärviből való faliszőnyegen; madárforma bronzcsüngő Vesilahtiból; ezüst nyakláncok a kuusamói kincsleletből, az ékszer lapján az életfa képe; ezüst nyaklánc Käkisalmiból; faragott rokkalap, rajta életfán ülő madarakkal Teerijärviből; vadászíj Sotkamóból; ezüstdíszes kard Eurából, csatabárd Maskuból, lándzsahegy Rapolából; ezüst női ékszerek Sakkolából; aranyozott csat és bronz szerszámcsüngő Tytärsaariból; ezüstlemez csüngők a janakkalai kincsleletből; szarvasfejjel díszített kőbuzogány töredéke Säkkijärviből; ezüst nyakkarikák a kuusamói kincsleletből; ezüst kereszt Maaria-Taskulából, bronzkereszt Ristimäkiből; két kés csonthüvellyel a Lappföldről; bronz ékszerek Kinnulából; ünnepi ivóedény Ruskóból, mellette kis csanak; madárformájú bronzékszer Vesilahtiból; díszes sajtformák Nyugat-Finnországból; madárformájú edények - ivócsanak és halas tálka - Tammelából, Uurainenből és Ylitornióból; férjes asszony főkötője Rautu-Sakkolából; négy faedény Orimattilából, Tuusulából, Mäntsäläből és Kemi vidékéről; három lappföldi csontkanál; guzsaly, szösz és orsó Ilomantsiból; két sarló Rautjärviből, illetve Nilsiäből; faragott rokkalap Raippaluotóból; főkötő hímzett homlokrésze Karjalából; mesebeli szörny egy kardmarkolat gombján Vesilahti-Kirmukarmuból; kígyóformájú bronzcsatok Eurából, Kangasalából és Isokyröből; három viking kori kard Ylöjärviből, illetve Kalvolából; útravaló ételt tartalmazó fa- és háncsedények Pusulából, Sipooból és Pälkänéből; színes gyöngyökből füzött nyakláncok Vyöriből; két favágó fejsze Kymiből, illetve Vihantiból; szarvból készített kürtök Lehtimäkiből; ezüst nyaklánc a halikkói kincsleletből; ezüst karperecek, nyakkarika és csatok a kuusamói kincsleletből; viking kori kard Tyrväntőből; ló alakú bronzékszer ikaalinenből; három kardmarkolat Vesilahtiból, illetve Maariából; bronz ékszerek: madár-, illetve kígyócsüngő Kuhmoinenből és Papinsaariból; doboz tetejének töredéke, viking kori díszítéssel Pudasjärviből; három nyírfakürt Viljakkalából; az állatok istennőjét jelképező hímzés ilomantsiból; kerek, nap formájú ezüstfüggő, rajta az életfa jelével, Hiitolából; bronz nyaklánc Nastolából; női övkarikák késsel, tütartóval a Lappföldről; viking kori bronz ékszerek Laitilából, Kokemäkiből és Hattulából; ezüstkereszt Krisztus képmásával a halikkói kincsleletből.

${ }^{313}$ RÁCZ 1980: 408. [kiemelés tőlem V. P. I.]
} 
azokon a pár soros Kalevala-idézeteken keresztül kapcsolódnak, melyeket a fordító választott melléjük. ${ }^{314}$

Az új koncepció tehát, amiben Nagy Kálmánt követi ugyan, de más módszerekkel, a forráskultúrát központba helyező megmutatás gesztusa.

\subsection{A honosított Kalevala - Szente Imre fordítása}

Szente Imre fordítása fogadtatásának kulcsszava a honosítás. A magyarrá tevés több szinten is működik: a formai mellett a magyar kultúrához köthető és a magyar irodalmi vendégszövegeken keresztül tartalmi szinten is. A fogadtatásban a fordításra reagálók és maga a fordító is - előés utószókban, műhelytanulmányában, a vele készült interjúban - innen közeledve keresik a teljes fordítások sorában és a magyar többrendszerben az ötödik magyar Kalevala helyét.

\subsubsection{Kiadói politikák - politika a kiadatásban}

A fordító saját bevallása szerint már 1984-ben készen állt a szöveggel, azonban a magyarországi kiadók nem vállalták a megjelentetést. ${ }^{315} \mathrm{Az}$ 1980-as évek Magyarországának politikai légkörében Szente Imre nem tartozott a kiadható szerzők/fordítók sorába. Ennek több oka is volt. Szentének 1956-ban kellett menekülnie Magyarországról. Hároméves ausztriai tartózkodás után Svédországban telepedett le. Időközben tizenhárom évig Finnországban élt, amikor a Jyväskyläi Egyetemen tanított a magyar nyelv lektoraként. A Kalevala-átültetés kiadásának elutasításában valószínúleg közrejátszott az is, hogy Szente fordította Szolzsenyicin Gulágját magyarra. ${ }^{316}$

A Kalevala-fordítás végül 1987-ben jelent meg először Münchenben, a Nemzedékek és Nemzetőr közös kiadásában, ${ }^{317}$ kis példányszámban.

\footnotetext{
${ }^{314}$ „Hogy a régi leletek és a kalevalai runók egybecsengését hatásosabban érzékeltessem, két-három verssort is írtam a képek mellé, utalva így az eposz megfelelő helyére. Felvételeim többnyire tárgyias példái az énekben említett eszköznek vagy ékszernek." Uo. 408.

${ }^{315}$ Szente arról írt, hogy 1984-ben Weöres Sándor támogatta a fordítás megjelenését. Weöres az Európa Kiadó elnökéhez, Illés Endréhez írt ajánlást a fordításról, ebből idéz Szente: „Olvasgatom Szente Imre remek Kalevala-fordítását, csupa jóhangzás és pontosság, ajánlhatom-e kiadásra?" SZENTE 2000: 95.

${ }^{316}$ A Gulág két kötetben 1975-1976-ban jelent meg Münchenben a Danubia-Nemzetőr közös kiadásában.

${ }^{317}$ A Tollas Tibor alapította és szerkesztette Nemzetőr emigráns irodalmi lap és Nemzedékek kiadó, mely az emigrációban élő magyar alkotók műveit, fordításait publikálta.
} 
Magyarországon csak a politikai rendszerváltást közvetlenül megelőző időszakban, 1988-ban és 1989-ben született ismertetések foglalkoztak nyíltan a fordító életpályájával éppen Kalevala-fordítása apropóján. ${ }^{318}$ Azonban a megjelentetés még váratott magára. Csak jóval később, a 2000es években jelenhetett meg, akkor azonban gyors egymásutánban kétszer is. Az első, a 2001-es szombathelyi megjelenés hiánypótlónak számít: a Berzsenyi Dániel Tanítóképző Főiskola Uralisztika Tanszékének Minoritates Mundi sorozatában jelenhetett meg. Nem véletlenül éppen Szombathelyen, Vas megyében. A fordító ugyanis Vas megyében, Celldömölkön született. A fordítás kiadásának felvállalását bevallottan is a fordító származása indokolta.

A 2002-es kiadás a Bárczi Géza Kiejtési Alapítvány gondozásában jelent meg. Az alapítvány, melynek tiszteletbeli elnöke maga a fordító, célja a zárt $e$ hang megőrzése a magyar nyelvben, ennek érdekében pedig olyan szövegek publikálása, melyek jelölik is ezt a hangot. ${ }^{319}$ A Szente-féle szövegről tudnunk kell, hogy a fordító jelöli a zárt $e$ hangot: $\ddot{e}$-vel. Ezzel pedig kitűnően illeszkedett az alapítvány kiadási politikájába.

\subsubsection{Az újrafordítói szerep és megnyilvánulásai}

Szente a célszövegeket a magyar többrendszer részének tekintette. Arról, hogyan is lehet megvalósítani a célkultúrába ágyazást, Szente az említett kiadások fordítói elö- és utószóiban, a vele készített interjúban és fordítói mühelytanulmányában vall.

Egy olyan személy nyilatkozott meg a fordításon és a mühelytanulmányon keresztül, aki 30 évnyi Magyarországtól való távollét után, emigrációban élő magyarként, az anyanyelv próbájaként élte meg a fordítás folyamatát. A forrásnyelv ismerete csak egy eszköz, mely a fordításon keresztül alkalmat teremt az anyanyelvvel való találkozásra, melyet a „szerelmi egyesüléshez" hasonlít.

Szente úgy látta, hogy a három új Kalevala-fordításban éppen az a közös, hogy mindannyian az anyaország határain kívül élő fordítókként egyszerre vizsgáztak a fordítói szerepből és anyanyelvi kompetenciából.

De miért tartotta fontosnak újra lefordítani a teljes Kalevalát? Egy szöveg újrafordítói munkájukat nyelvi és/vagy poétikai szempontokkal legitimálják, többnyire az előző fordításokkal szemben. Szente az első kiadás

\footnotetext{
${ }^{318}$ Vö. JÁVORSZKY 1988., LISZTÓCZKY 1988. és DOMOKOS 1989.

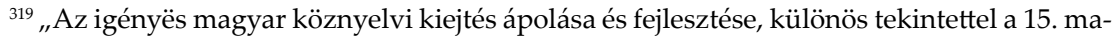
gánhangzó (az úgynevezëtt zárt e = ë hang) mëgőrzésére a társalgás, a fëlolvasás és a különféle előadások hangzó nyelvében. Ennek érdëkében kiejtésjelöléssel ellátott könyvek kiadása, pályázatok kiírása, vers- és prózamondó, kiejtési, fëlolvasási versënyëkën különdíjak adományozása, illetve ilyenëk szërvezése." http://barczi.uw.hu/ Letöltve 2008. szeptember 17.
} 
előszavában elhatárolódott a korábbi fordításokhoz való kritikai hozzáállástól, amikor hangsúlyozta, hogy az új átültetés nem az addigiakkal való elégedetlenségből született. ${ }^{320}$ Saját fordítását a magyar Kalevalák sorába nyelvi szempontok alapján sorolta be: „középúton jár Vikár erősen archaizáló s tájszavakban is bővelkedő nyelve, valamint az újabb fordítások közérthetősége, s a köznyelv határain belül maradó nyelvhasználat között, mintegy szintézise a két végletnek." ${ }^{321}$ Mühelytanulmányában azonban már rámutatott azokra a megoldásokra, melyek megkülönböztetik fordítását elődei szövegeitől. Saját szövegét a Nagy Kálmánénál szöveghűbbnek tartotta, a Rácz István által használt väinämöineni állandó jelzőt - a "vénséges vén” szemben az általa használt „vének vénje” - a ritmikai pontatlanság és a nem megfelelő jelentéstartalom miatt bírálta, Vikár Bélát pedig Lemminkäinen másik megnevezése, a Kaukomieli pontatlan fordítása miatt: a Messzivágyó Szente szerint „holmi ábrándos széplélekre” utalt, ellentétben az ő megoldásával, a Kalandoskedvűvel, mely jobban illett a szereplő természetéhez. ${ }^{322}$

Szentének a magyar Kalevala nyelvéről is határozott elképzelése volt. Ebben Vikár nyomdokait követte: a költőiség és a népi vonások - pl. nyelvjárási szavakon és kifejezéseken keresztül - megjelentetését tartotta igazán fontosnak. Fordítói célkitüzésként nála is megjelent, amint az az 1930-as években is jellemző volt, hogy a Kalevalát népkönyvvé kell tenni Magyarországon. A népkönyvvé válás gondolata tükröződik a fordítás tipográfiájának magyarázatában is. Az első ránézésre formabontó, hagyománytörő tipográfia prózaszerúségével lep meg. Barna, Vikár és Nagy nyolc szótagos, Rácz tizenhat szótagos verssorai után ez a Kalevala azért csak prózaszerü, mert - Szente saját bevallása, recenzensei és kritikusai szerint is - a folyamatos szövegben igyekezett megtartani az időmértékes kalevalai ritmust. Formailag a közvetlen fordító-elődök gyakorlatát követte: Vikár felező nyolcasai helyett a trochaikus lejtést alkalmazta, mint Nagy Kálmán, és Rácz Istvánhoz hasonlóan az alliterációk minél nagyobb számú visszaadását kísérelte meg. ${ }^{323} \mathrm{~A}$ fordítás formai hüségéről mindenki elis-

\footnotetext{
${ }^{320}$ SZENTE 1987: 6.

${ }^{321}$ Uo. 9.

322 SZENTE 2003: 113-118.

${ }^{323}$ Lisztóczky László kimutatása alapján betűrímekben nem csupán az előző fordításokat, hanem magát a finn eposzt is túlszárnyalja: „ha összehasonlítjuk a finn eredeti és az öt teljes magyar fordítás (sorrendben: Barna Ferdinánd, Vikár Béla, Nagy Kálmán, Rácz István és Szente Imre) alliterációinak adatait, a következő eredményt kapjuk: a második ének első száz sorában 80, 21, 56, 56, 100, 194, a negyedik ének második száz sorában 83, 19, 43, 51, 99, 137, a kilencedik ének első száz sorában 80, 23, 54, 67, 100, 174 betürímes szót találunk." LISZTÓCZKY 1998: 109.
} 
merően nyilatkozott. ${ }^{324}$ Csepregi Márta szerint ebben élen járt az öt magyar Kalevala-fordító között.

A különös tipográfia a magyarországi megjelenés előtt bizonyult központi problémának a Budapesten született ismertetésekben. Müfajában így lett az ötödik teljes magyar fordítás versregény és regényes vers, vagy éppen mese és regény eposzi ötvözete. Szente éppen ezzel a műfaji sokszínűséggel akarta a Kalevalát népivé tenni, és „leszállítani arról az eposzi magaslatról, ahová Lönnrot igyekezete és hosszú évek csodáló tisztelete emelte." 325

A formai jellegzetességekkel nem foglalkozom bővebben, mert bár az 1849-es finn kiadáshoz képest jelentős újításokat tartalmaz, a Kalevala finnországi hatástörténetében az újabb kiadások éppen formai újításaikkal keltettek nagy érdeklődést. Gondoljunk csak Rácz István okfejtésére, amivel fordításának tördelési módját magyarázta. ${ }^{326}$

Szente stratégiáját tehát a célkultúra-központúság jellemzi, mely a honosítás különféle módjaiban ölt testet.

\subsubsection{A honosítás módjairól}

A honosítás egyik módja a kifejezetten a magyar kultúrkörhöz kapcsolódó fogalmak használata, a másik pedig a magyar irodalmi vendégszövegek beemelése a célszövegbe. A fogalmi keret azonban, melyben mindez történik, nem a Barna Ferdinánd-i és Vikár Béla-i stratégiákkal karöltve, hanem éppen azokkal szemben tételeződik.

\subsubsection{A célkultúra előtérbe helyezése}

Legyen az műköltészet, népköltészet, nyelvjárási szó, a köznapi tevékenységekhez kötődő fogalom és nem utolsósorban a keresztény katolikus vallásra való konkrét utalás vagy éppen magyar irodalmi és a korábbi fordításokból vett vendégszöveg, Szente célja ezekkel a „hazafelé célozgatásokkal" az volt, hogy a magyar olvasóban egyfelől magyar asszociációkat ébresztgessen, másfelől, hogy az olvasó „,az édes honi ízekkel-zamatokkal vegyítve az idegenben a sajátjára ismerve gyönyörködhessen." 327

A szövegben egyaránt találkozunk a magyar totemállatokkal: a turulmadárral és a csodszarvassal, Kisboldogasszonnyal és Nagyboldogaszszonnyal. A népmesék Óperenciás tengere mellett ungon-berken kergeti

\footnotetext{
${ }^{324}$ CSEPREGI 1993b. 1465., FEHÉRVÁRI 2002a: 88., VARGA 1990: 131.

${ }^{325}$ SZENTE 1987: 9.

${ }^{326}$ RÁCZ 1976: 400-405.

${ }^{327}$ SZENTE 2000: 91.
} 
Lemminkäinen a szarvast, ugyanakkor a népdalok egy-egy sorára is ráismerhetünk Zrínyi Miklós, Vörösmarty Mihály, Arany János, Ady Endre és mások műveiből vagy éppen az Ómagyar Mária-siralomból, Kőműves Kelemenből kölcsönzött szövegek mellett. ${ }^{328}$ A népi jelleget a vendégszövegek mellett a köznyelvben már nem használatos szavak felélesztésével, a különösen vasi nyelvjárási szavakkal és köznyelvben már úgyszintén nem használatos elbeszélő múltú és félmúltú igealakok szövegbe illesztésével óhajtotta visszaadni a fordító. ${ }^{329}$

Szente honosító módszereiről megoszlott a fordításról tanulmányt vagy recenziót írók véleménye. Csepregi Márta a magyar kultúrkörhöz tartozó fogalmak fordításbeli jelenlétéről a fordítói szabadság és a fordítói realizmushoz kapcsolható „mindenben hű fordítás” ideáljának szempontját felvetve írt elfogadóan. ${ }^{330}$ Domokos Péter és Fehérvári Győző más-más elméleti alapokról kiindulva kritikusan viszonyult a szentei honosításhoz. Domokos korábbi írásaihoz képest is meglepő módon egy "filológiailag egészen pontos átültetés" igényét fogalmazta meg. A magyar klasszikafilológia berkeiben divatos filológiai pontosság jegyében nem a nagy olvasóközönségnek szánta, hanem a szakemberek és műfordítók szűkebb köre számára. Fehérvári viszonyulásában a forrás- és célkultúra-központúság egyaránt tetten érhető volt. Bizonyos megoldásokat a forráskultúrával való össze nem egyeztethetőség szempontjából tart kifogásolhatónak, másokat pedig a célkultúrának való megfeleltethetőség miatt jónak. A magyar irodalmi vendégszövegeket, a magyar népmesei motívumok beillesztését és a magyar népi imádságokból jól ismert Nagyboldogasszony-Kisboldogasszony kifejezés alkalmazását elfogadhatónak tartja, de az Óperenciás-tenger és a turul használatát már túl magyarosnak érzi. ${ }^{331}$

\footnotetext{
${ }^{328}$ Csak a legjellemzőbbek Szente műhelytanulmányából: „amikor Lemminkäinen különféle varázsolásokkal szédíti a lányokat, terükre tavat varázsol, tó vizére kék kacsákat: kék a háta, zöld a szárnya, sárgaréz a sarkantyúja. Világos, hogy itt is magyar népdalra utalok: Zöld erdóben, zöld mezóben sétál egy madár, kék a háta, zöld a szárnya, jaj be gyöngyen jár. (...) Az Ómagyar Mária-siralomra utal a világ virága; maga teremtette mókusfiát szólítja így a tündérasszony: Dombok éke, drága móka, aranyom, világ virága! Joukahainen, a pórul járt incifinci lapp legényke így könyörög irgalomért Väinämöinenhez: nyavalyámbul nyújts ki mostan! (a forrás ugyanaz). Nosza sírni kezd, zokogni - írtam Ágnes asszonyra gondolva; csüggenek szaván - a Családi körre; Fegyvert, férfit hol kerítek - Zrínyire; (...) mikor Istennek ideje, eljö Úrnak érkezése - utalás Ady versére." SZENTE 2003: 119-122.

${ }^{329}$ A nyelvjárási szavakra néhány példa: csiggat, sülülü, vella, grábla, vonyogó, kalán, terü, himpér, fölöstök, kakastéj, izink, mony, pipe, pipécske, lile, zsiba, csuri, fészekfentő, kódis, habókos, dilinós, eceboca, bugyuta, mazna, toszonkos, csökött, hupikék, tulpiros, csicsás, ajja-fajja, retyerutyája, pereputtya, babirkál, csácsog, picsog, kornyikál, kujtorog, csupál, hangicsál, zöngicsél, bándigál, bucsálódik, pocskolódik, viribül, leszotyorodik, megiperedik, neszüdik, kípesint, piripofa-vaskemence, gyak, gyakint, alít. Uo. 117-119.

${ }^{330}$ CSEPREGI 1993b: 1467.

${ }^{331}$ FEHÉRVÁRI 2002a: 89.
} 


\subsubsection{A finugor háló elvetése}

A honosítás, amint azt Barna Ferdinánd és Vikár Béla fordításának fogadtatásában is láttuk, történhet a finnugor hálón belül. Ennek legfőbb vonása olyan fogalmi keret megteremtése, mely az egyedítést szolgálja azoknak a másságoknak a felerősítésével, melyek megkülönböztetik a nyugati hálótól. Szente célkultúra-központú fordítása, honosítási módszerei akár ilyen egyedítő törekvéseknek is tekinthetőek.

A fordításkiadások elő- és utószóiban vagy a mühelytanulmányban erre nem találunk utalást. Egyedüli kiindulópont a Szentével készült interjú, amelynek mintegy kétharmada foglalkozik a Kalevalával. A fordítónak feltett kérdések a finnugor hálóhoz kapcsolódnak, mégpedig a Barna Ferdinánd-i finnugor - és ezen keresztül magyar - mitológiát rekonstruáló törekvésekhez és a magyar-finn néprokonság bizonyításának lehetőségére. Szente stratégiái és az újrafordítás okai mögött az első Kalevala-fordítók célkitűzését: az elveszett magyar ősepika pótlását keresi a kérdésfeltevő. A fordítást a magyar ősvallás rekonstruálásának egyik eszközeként olvassa, a célkulturális elemeket pedig ,, a töredékeire hullt pogány magyar hagyomány kakukktojásainak a rokonnak érzett fészekbe" becsempészéseként. A fordító válaszaiban igyekszik elhatárolódni elődei törekvéseitől, és a néprajztudomány, valamint az összehasonlító nyelvészet eredményeire utalva elutasítani a magyar mitológiának a finnugor mitológián keresztüli rekonstruálhatóságát vagy a néprokonság lehetőségét. Szente elveti annak a lehetőségét, hogy ő ezen a hálón belül müködtetné az általa használt egyedítő eszközöket. Meglátásában a magyarrá tevés, a célkultúrába ágyazás nem a finnugor hálón belül működtetett hagyomány átöröklése révén, hanem az élő hagyomány, az írott kultúra elemeinek a fordításba emelése által valósítható meg.

\section{5. Összegzés}

Az 1950-es években a magyar irodalmi gondolkodásban bekövetkezett változás új fordítások szükségességét indokolta. Több mint fél évszázaddal Vikár Béla fordításának megjelenése után az újrafordítást felvető legfőbb okok egyike fordítása nyelvének és formai megoldásainak az elavulása volt. Az újabb Kalevalákról szóló írásokról elmondható, hogy többnyire recenziók, majd a 70-es évektől olyan tanulmányok, mely az öt teljes magyar fordítást helyezték a vizsgálat fókuszába. Nagy Kálmán fordítása, a klasszikussá vált Vikár-szöveg érinthetetlensége folytán, nem ingatta meg annak központi helyzetét. Erre csak az 1970-es évek végén került sor, mi- 
után Rácz István átültetése is megjelent. Bár a teljes Rácz-szöveg nem jelent meg 1980 óta, a Diákkönyvtár szemelvényes Kalevalái - a 2007-es kiadást kivéve, mely Vikár szövegét tartalmazza - ezen a fordításon alapulnak.

A három utolsó Kalevala-fordító az eposz egy-egy formai sajátosságát emelte ki: a paralelizmust, az alliterációt és a trochaikus lejtést.

Nagy Kálmán fordításában a paralelizmusok lettek igazán fontosak. Amit mások monotóniának véltek, abban ő a változatosságot, a belső ritmust kereste. Nagy köznyelven megszólaló Kalevalája az 50-es és 60-as években már-már dogmatikussá vált formai hűségét igyekezett megvalósítani. Ezt sikerrel meg is oldotta, hiszen a harmadik Kalevala-fordítás legfőbb erényének a köznyelvúség mellett a pontosságot tartották.

A Nagy-szövegre vonatkozó negatív kritikákban a meglepettség és a csalódás egyszerre jelen volt: a Vikár-fordításhoz objektívebben viszonyuló, az újrafordítás kérdését felvető hangok már az 1960-as években jelentkeztek, csak éppen Képes Gézától várták a „megüresedő hely” betöltését. ${ }^{332}$ Nagy Kálmán egyfelől túlságosan idegen és ismeretlen volt, hogy az elődje által elfoglalt helyet betölthesse, másfelől pedig a 70-es években még élt a remény, hogy Képes befejezi elkezdett fordítását. Amikor a 70-es évek második felében Rácz István publikálta Kalevala-átültetését, az kielégítette a Képessel szemben támasztott elvárásokat (is), valamint a Vikár nyomdokain haladó, a költőiséget szolgáló fordítási megoldásokkal nem hozott annyira radikálisan újat, mint a Nagy-szöveg, amit többek között éppen a vikári népies és archaikus szóhasználattal szembeni köznyelvüség-igény hívott életre.

Rácz István az alliterációt tartotta a Kalevala kulcsának. Fordításának fogadtatásában a két közvetlen fordítóelőd - Vikár Béla és Nagy Kálmán - átültetésének fogadtatásában megnyilvánuló hatások ötvöződtek, különösen két szempont: a költőiség és a köznyelvűség. A költőiség megvalósításának eszköze - az alliterációk használata - megosztotta ugyan kritikusokat, de a rangsorolásra vállalkozók éppen ebben látták a költőisége zálogát és emiatt tartották érdemesnek arra, hogy a Vikár-fordítás helyét a magyar irodalmi köztudatban fokozatosan átvegye. Amint arra Péli Árpád is rámutatott, Rácz Kalevala-fordításának központba kerülése ugyanazoknak a szempontoknak mentén történt, mint korábban Vikár fordítása esetében: a népies jelleg és a költőiség múködött hívó szóként a vikári szöveg fogadtatásában. Nagy Kálmán fordításához pedig két ponton is kapcsolódik: a köznyelvűség és a megmutatás stratégiájának felvállalásában. Kétféle ol-

${ }^{332}$ 1969-ben mutatta be a budapesti Körszínház Kalevala-előadását Kazimir Károly rendezésében. Az előadás szövegének alapját az ismert fordító, Képes Géza átültetése képezte. 
vasói elvárásnak is meg akart felelni Rácz átültetése: népies köznyelven és költőien szólni az olvasóhoz.

Szente Imre az alliterációk mellett a trochaikus lejtés megtartását tartotta fontosnak. Prózaszerű fordításába olyan célkulturális elemeket és fogalmakat illesztett, melyekkel honosítani, magyarrá tenni igyekezett szövegét.

Rácz és Szente a magyar kultúrkörtől földrajzilag távol él(t) és alkot(ott): Helsinkiben és Stockholmban. Számukra az eposz újrafordítása személyes kihívás volt, bizonyítási vágy: hogy Magyarországtól távol élve még mindig tudnak magyarul. A célnyelv és -kultúra előtérbe helyezése az első két fordító célkitűzéseihez közelíti az utolsó két fordítást.

Az előbbiek figyelembe vételével a célszövegek összehasonlító vizsgálata előtt a következő elvárások fogalmazódnak meg:

- Nagy Kálmán analitikus fordítása a formailag is lehető legpontosabb átültetés létrehozását tekinti célnak. A formai hűség és a megmutatás gesztusa a forráskultúrához köthető elemek megtartását jelenti, legyen szó az eposzban előforduló reáliákról, földrajzi és személynevekről, a magyar helyesírástól idegen alakokról.

- Az (erdélyi) köznyelvü és archaizmusoktól mentes magyar szöveg forráskultúra-központú, és a Vikár Béláétól teljességgel eltérő koncepcióról árulkodik. Ha a fordítás megjelenési helye és a fordító személye egyaránt illethető az erdélyi jelzővel, a fordított szöveg nyelvhasználata alátámasztja ezt, ahogyan erre a fogadtatásban is utaltak.

- Rácz István szövegében a költőiséget szolgáló alliteráció és a népies jelleg a meghatározó.

- A budapesti kiadásban publikált illusztrációk mellett a megmutatás más, a finn kultúrához köthető elemekben is megnyilvánul.

- Szente Imre a kifejezetten magyar kultúrkörhöz kötődő fogalmak beiktatásával olyan célkultúra-központú szöveget teremt, melyben nincs helye a megmutatásnak, a forráskultúra elemei beillesztésének.

- A fordítás a magyar írott kultúra hagyományába a vendégszövegeken keresztül illeszkedik. 



\section{A TELJES MAGYAR KALEVALÁK ÖSSZEHASONLÍTÓ VIZSGÁLATA}

A forrás- és célszövegek konkrét összevetése elengedhetetlen része a rendszerelvü, leíró fordítástudományi elemzésnek. Azonban ismételten hangsúlyoznom kell, hogy ez fordításvizsgálatomnak nem célja. Ez egy eszköz az előfeltevések megerősítésére vagy éppen cáfolására, valamint az öt teljes magyar Kalevala egymáshoz való viszonyának és a célrendszerben betöltött szerepének a meghatározására.

A magyar fordítások összehasonlító vizsgálata és a finn szöveggel való összevetése első lépésben általánosabb szinten mozog: a formai és tartalmi különbségeket és hasonlóságokat elemzem az eposz egészében, ezt követi az átváltási műveletek vizsgálata az eló- és utóhangban. Teszem mindezt úgy, hogy a fogadtatásban felmerült szempontokat, a fordítások megjelenése idejének fordításról való gondolkodását és az előző fejezetek végén megfogalmazott elvárásokat szem előtt tartom.

A célszövegeknek a forrásszöveggel való nyelvészeti összevetésében a grammatikai és lexikai átváltási műveletek vizsgálatakor - Klaudy Kinga osztályozását követem. Klaudy a fordítás folyamatában a következő múveleteket különbözteti meg: konkretizálás és generalizálás, felbontás és összevonás, kihagyás és betoldás, áthelyezések és cserék. ${ }^{333}$

Bár esetünkben rokon nyelvekről van szó, és a grammatikai rendszer igen nagy hasonlóságot mutat, a finn és a magyar nyelv grammatikai rendszere között vannak különbségek, ezért grammatikai átváltási műveletekre is szükség van.

A vizsgálat előtt lássuk még egyszer, milyen elvárásokkal közeledünk a szövegek felé:

- Barna Ferdinánd célkitüzéseiben a finnugor háló - ezen belül pedig

- egy finnugor és magyar mitológia letéteményese kíván lenni. A fordításkiadás etimologizálásai és magyar vonatkozású jegyzetei a szövegben is érvényre jutnak.

${ }^{333}$ KLAUDY 1997: 115-116. 
- A forráskultúrára utaló elemeket csak akkor tartja meg, ha valamilyen módon a magyar kultúrához kapcsolhatóak.

- Vikár Béla, elődjéhez hasonlóan a finnugor háló megteremtését tüzte ki célul. A szóhasználat terén, a magyar népköltészetből és dialektusokból is merítő célszöveg ezt szolgálja.

- A célnyelvi befogadóhoz úgy hozza közelebb a szöveget, hogy a legtöbb idegenséget hordozó, a finn kultúrához köthető elemeket a magyar kultúrához igazítja. Ez a stratégia érvényesül a formai megvalósításban is: a felező nyolcas sorok és a végrímes formai megoldás választásában.

- Nagy Kálmán analitikus fordítása a formailag is lehető legpontosabb átültetés létrehozását tekinti célnak. A formai hüség és a megmutatás gesztusa a forráskultúrához köthető elemek megtartását jelenti, legyen szó az eposzban előforduló reáliákról, földrajzi- és személynevekről vagy a magyar helyesírástól idegen alakokról.

- Az (erdélyi) köznyelvü és archaizmusoktól mentes magyar szöveg forráskultúra-központú, és a Vikár Béláétól teljességgel eltérő koncepcióról árulkodik. Ha a fordítás megjelenési helye és a fordító személye egyaránt illethető az erdélyi jelzővel, a fordított szöveg nyelvhasználata alátámasztja ezt, ahogyan erre a fogadtatásban is utaltak.

- Rácz István szövegében a költőiséget szolgáló alliteráció és a népies jelleg a meghatározó.

- A budapesti kiadásban publikált illusztrációk mellett a megmutatás más, a finn kultúrához köthető elemekben is megnyilvánul.

- Szente Imre, a kifejezetten magyar kultúrkörhöz kötődő fogalmak beiktatásával olyan célkultúra-központú szöveget teremt, melyben nincs helye a megmutatásnak, a forráskultúra elemei beillesztésének.

- A fordítás a magyar írott kultúra hagyományába a vendégszövegeken keresztül illeszkedik.

\subsection{Különbségek és hasonlóságok a célszövegekben}

Barna Ferdinánd és Nagy Kálmán fordításának esetében problémamentes volt a vizsgálatot képező szöveg kiválasztása. Barna szövege csak egyszer jelent meg - 1871-ben. A Nagyé ugyan kétszer, de mindkét kiadás a fordító halála után. Az 1972-es, bukaresti kiadást veszem alapul. Rácz István és Szente Imre szövegváltozatai közül pedig a legutolsó teljes kiadások szövegét: az 1980-ban és a 2002-ben megjelentet. A legproblemati- 
kusabb a Vikár-szöveg kiválasztása volt. A probléma abból adódik, hogy három szövegváltozat is rendelkezésünkre áll: az 1909-es első kiadás, az 1935-ös jubileumi és az 1980-as, mely bizonyos mértékben különbözik az 1909-es kiadástól. Végül úgy jártam el, mint az utolsó két fordítás esetében: a fordító által végsőnek tekintett szövegváltozatot vettem alapul, vagyis az 1935-ben megjelentet. Ahol szükségét érzem, ott utalni fogok a többi szövegváltozatra is, az említetteken kívül az 1901-es Lemminkäinenről szóló énekek kiadására vagy a 2007-es Voigt Vilmos által válogatottra és szerkesztettre.

\subsubsection{A fordítások formai jellemzői}

A finn Kalevala formai sajátosságai közé tartozik a paralelizmus, az alliteráció és a kalevalai ritmus. A forrásszöveg ezen jellegzetességei közül, a fordítói előszavak és műhelytanulmányok tanúsága szerint, a magyar fordítók többnyire egyet emeltek ki és helyeztek fordítói stratégiájuk középpontjába.

\subsubsection{Paralelizmus}

A paralelizmus vagy gondolatritmus azt jelenti, hogy az eposzban szinte kivétel nélkül két sor alkot egy egységet: a második sor szinonimákkal és árnyalatnyi különbséggel ismétli az első sorban levő gondolatot. Új gondolatot nem közöl.

A paralelizmus átültetését különbözőképpen valósították meg a fordítók. Barna Ferdinándnál például az is előfordult, hogy egy-egy négy sorra kiterjedő paralelizmust lerövidített: csupán két sornyit tartott meg belőle. Vikár többnyire mindent lefordított, a sorvégi rímekkel még rá is erősített a sorok összetartozására. Nagy Kálmán az, aki mindenekelőtt a paralelizmus, valamint a kalevalai ritmus célszövegbeli megvalósítását tartotta szem előtt. Saját bevallása szerint a gondolatritmusban nem a monotonitást, hanem éppen ellenkezőleg, a második sorban a szinonimákkal a változatosságot akarta érzékeltetni. Azt, hogy miként lehet ugyanazt a dolgot különféleképpen elmondani. Az utolsó két fordítás az őket megelőzőektől különösen tipográfiájukban különbözött. Rácz István a 60-as és 70-es évek finn Kalevaláinak mintájára többnyire tizenhat szótagos sorokból építette fel eposzát. Így a gondolatritmus összetartozó sorai nem egymás alá, hanem egymás mellé kerültek. Ezzel a módszerrel sikerült elkerülnie a paralelizmusból fakadó sorvégi rímeket, melyek nála is előfordulnak, ugyanakkor természetszerüleg nála található a legtöbb belső rím. Szente Imre 
Kalevalája pedig prózaszerü, azonban megtartotta a forrásszöveg minden gondolatritmusát.

\subsubsection{Trochaikus, időmértékes sorok}

A kalevalai ritmus a trochaikus sorokra épül. A többnyire nyolc szótagból álló sorok (az eposzban vannak kilenc és tíz szótagból állók is) a magyar, 2x4-es felbontású, hangsúlyos verselés alkalmazására "csábította” a fordítókat, különösen Vikár Bélát. A finn trochaikus sorból azonban hiányzik a cezúra, ami a hangsúlyos magyar verselésnek állandó velejárója. Vikár Béla egyik műhelytanulmányában a két verselési forma ekvivalenciájával magyarázta választását: ami a finneknél $4+4$ trocheus, az a magyarban a cezúra elválasztotta nyolc szótagos sor. Ugyanakkor arra is felhívta a figyelmet, hogy a finn trocheus nem azonos a magyar időmértékes versek trocheusával. $\mathrm{S}$ bár a forrásszövegben vannak kilenc és tíz szótagos sorok is, ilyen fajta kivételek a magyar népköltészetben is igen gyakoriak. Vikár meglátásában ezek hivatottak szolgálni a változatosságot, valamint a magyaros verselés alkalmazása az egyik módja annak, hogy a finn Kalevalát a magyar olvasóhoz igazán közel hozza.

A 20. század második felében éppen a vikári formai megvalósítás volt az egyik ok, ami az újrafordítás kérdését felvetette. Ezért is válhatott a „formai hűség” Nagy fordításának központi kérdésévé. Rácz István is arra törekedett, hogy amennyire lehet, megtartsa a kalevalai ritmust. Amint az előző fejezetben már utaltam rá, ritmikailag mégis Szente Imre fordítását tartják a forrásszöveghez legközelebb állónak. Csepregi Márta vizsgálata alapján az öt teljes magyar Kalevala-fordítás közül az utolsó az, amely leginkább érvényesíti a trochaikus lejtést. Szente fordítása ugyan folyamatos szöveg, prózaszerü. Csak szerü, mert - Szente saját bevallása szerint és kritikusai szerint is - a folyamatos szövegben igyekezett megtartani az időmértékes kalevalai ritmust.

\subsubsection{Alliteráció}

Az alliteráció tekintetében a magyar fordítóknak nehéz dolguk lehetett, hiszen a magyar nyelv hangrendszere, különösen ami a mássalhangzókat illeti, sokban különbözik a finn nyelvétől. A finn irodalmi nyelvből hiányoznak a következő hangok: c, cs, d (szókezdő helyzetben nem, csak a szó belsejében, a szónak csak ragozott alakjában fordulhat elö), dz, dzs, f, g, gy, ly, ny, s, ty, z, zs. Vagyis szókezdő helyzetben eleve kevesebb mássalhangzó fordulhat elö, mint a magyarban. Ezen túlmenően pedig a finn szöveg alliterációi nem csupán a szavak első hangjára vonatkoznak, ha- 
nem az első, a második, sőt néhol a harmadik hang is azonos. Rácz István és Szente Imre felvállaltan is az alliterációk minél teljesebb visszaadására törekedett. Az első két fordító a kiadások előszavában ugyancsak kiemelt helyen kezelte az alliteráció kérdését, összefüggésbe hozva a finn-magyar nyelvrokonsággal is, de célszövegbeli megvalósításában messze alulmaradtak a két utolsó Kalevala-fordítótól. Lisztóczky László kimutatása alapján betürímekben nem csupán az előző fordításokat múlja felül a két utolsó célszöveg, hanem magát a forrásszöveget is túlszárnyalja: „ha öszszehasonlítjuk a finn eredeti és az öt teljes magyar fordítás (sorrendben: Barna Ferdinánd, Vikár Béla, Nagy Kálmán, Rácz István és Szente Imre) alliterációinak adatait, a következő eredményt kapjuk: a második ének első száz sorában 80, 21, 56, 56, 100, 194, a negyedik ének második száz sorában 83, 19, 43, 51, 99, 137, a kilencedik ének első száz sorában 80, 23, 54, 67, 100, 174 betürímes szót találunk." 334

\subsubsection{4. Állandó jelzők}

Közvetetten bár, de a formai sajátosságokhoz sorolhatóak az állandó jelzők is. Az eposz három főhősének, Väinämöinen, Ilmarinen és Lemminkäinen jelzőinek vizsgálata különösen fontos.

Väinämöinen jelzője a vaka vanha alliterál is a hős nevével. Ezért is választotta Rácz István és Szente Imre a vénséges vén, illetve a vének véne kifejezéseket. A vaka 'igazmondó, derék, komoly' jelentésű melléknévhez Szente megoldása közelebb áll, mivel a vének véne inkább sugall bölcsességet és komolyságot, mint Rácz vénséges vén kifejezése. Nagy Kálmán derék öreg szószerkezettel fordította az állandó jelzőt. ${ }^{335}$ Vikár a komoly melléknevet használta, ami ugyan nem alliterál az öreg melléknévvel vagy a hős nevével, de pontos fordítása a forrásnyelvi szónak, akárcsak Nagy Kálmán megoldása. Barna Ferdinánd választása, a 'jámbor' melléknév, nem alliterál a hős nevével, és a vaka melléknév összetett jelentését sem adja vissza.

Ilmarinen állandó jelzője a legproblémátlanabb mindegyik közül: seppo 'kovács'. Mindenik fordítás megtartotta a hős foglalkozására utaló jelzőt, Vikár és Rácz a vasverővel váltogatta.

Lemminkäinen jelzője, a lieto ugyancsak alliterál a hős nevével. A melléknév jelentése 'könnyűvérü, léha'. Ez utóbbi kínálta önmagát a fordítóknak. Vikár, Nagy és Szente élt is a lehetőséggel. Barna választása - fürge - meglehetősen semmitmondó, a deli valamivel találóbb, mivel a hősnek az eposzban elbeszélt történetére reflektál. Rácz megoldása - könnyűked-

\footnotetext{
${ }^{334}$ LISZTÓCZKY 1998: 109.

${ }^{335}$ Érdekes fordítástörténeti adalék, hogy Kalevalából elsőként fordító Reguly Antal ugyanezt az állandó jelzőt használja.
} 
vü - fedi a lieto jelentését, de furcsa, hogy éppen Rácz István, aki mindenekelőtt az alliterációkat tartotta szem előtt fordításában, nem a léha szót választotta.

A Kalevala Lemminkäinenje több személy összeolvasztásából született Lönnrot íróasztalán. A több személyből Lönnrot még kettőt jelöl, amelyek többnyire a Lemminkäinenre utaló sorhoz kapcsolódó gondolatpárhuzamok második sorában fordulnak elő: Kaukomielit és Ahtit. A magyar fordításokban Ahti Ahtiként, Kaukomieli pedig Vikár 1909-es szövegváltozatában Messzivágyóként, az 1935-ösben pedig Messzikedvúként jelent meg. Véleményem szerint a Messzikedvú hangzása miatt - csak magas magánhangzókat tartalmaz - jobban illeszkedik a szövegbe. Rácz István is, elődjéhez hasonlóan, a Messzivágyót használta, ezt váltogatta a Könnyúkedvüvel és a finn Kaukomielivel. Nagy Kálmán melléknevesítette a tulajdonnevet, és Vikárhoz hasonlóan a messzikedvút használta. Szente Imre megtartotta a magas hangrendü -kedvű - utótagot, és összhangban a Lemminkäinentörténettel, a hős állandóan kalandot kereső jellemével, előtagként a kalandost használta, így lesz Lemminkäinen Kalandoskedvü.

\subsubsection{A nevek írásmódja a fordításokban}

Nagy Kálmán és Szente Imre szövegében a nevek a forrásnyelvi alakban jelentek meg.

Vikár Béla fordításának első kiadásában ugyanígy tett, csak az 1935ös kiadástól kezdődően magyarosította a nevek írásmódját. Ebben Rácz István is követte példáját. A gyakorlatban ez azt jelenti, hogy a finnben kettőzéssel jelölt hosszú magánhangzók a magyar helyesírásnak megfelelően, diakritikus jelekkel ellátva jelentek meg. Pl. Tuulikki - Túlikki, Lyylikki-Lülikki. Ez utóbbiban a finn y és a magyar $\ddot{u}$ ugyanazt a hangot jelöli. Rövid változata szerepel a Kylli(kki) - Külli(kki) névben is. Mivel a magyar nyelv a zárt és nyílt $e$ hang közötti különbséget írásban nem jelöli, Väinämöinen és Lemminkäinen nevében az utóbbit nem jelölték: Vejnemöjnen, Lemminkejnen. Az $i$ betüt $j$-re cserélték, idomulva a kiejtéshez.

Barna Ferdinándnál teljesen esetleges a rövid - hosszú magán- és mássalhangzók oppozíciójának a jelölése. Lemminkäinen vagy Kaukomieli nevének írásában Barna a finn írásmódot követte ugyan, de változtatott a név végén - Kaukomiely, Lemminkäy. Feltételezésem szerint ezek a formák elírások vagy nyomdahibák. 


\subsubsection{A forrásszöveg személy- és földrajzi nevei a célszövegekben ${ }^{336}$}

A tulajdonnevek fordítását majd minden fordításelméleti irányzat problematikusan kezelte. Léteznek ugyan irányelvek, egyesek a lefordításukat, mások pedig a forrásszövegbeli alak megtartását írják elő. Sokszor pedig a szöveg múfaja vagy célközönsége határozza meg az alkalmazott stratégiát. Azt gondolhatnánk, hogy azok az elvek, melyek a magyar Kalevalák fordítási folyamatának idején meghatározóak voltak, hatottak a fordítókra is, akik aztán egy választott stratégiát alkalmazva viszonyultak a tulajdonnevekhez. Lássuk, valóban így történt-e.

\subsubsection{A -tAr képzőjü nevek fordítása}

A -tar képzővel ellátott személynevek nőnemű egyént jelölnek.

Kezdjük a vizsgálatot egy olyan résszel, a Kalevala 32. énekének 8 sorával, ahol majd minden egyes sorban megjelenik egy -tar végü név:

Suvetar, valio vaimo,

Etelätär, luonnon eukko,

Hongatar, hyvä emäntä,

Katajatar, kaunis neiti,

Pihlajatar, piika pieni,

Tuometar, tytär Tapion,

Mielikki, metsän miniä,

Tellervo, Tapion neiti. (Kalevala, 32:83-90)

Nagy Kálmán az egyedüli, aki egyetlen nevet sem fordított le, megtartotta a forrásnyelvi szavakat és követte a finn írásmódot is:

Suvetar, szépséges asszony,

Etelätär, termő asszony,

Hongatar, jóságos asszony,

Katajatar, szép kisasszony,

Pihlajatar, kis leányka,

Tuometar, Tapio lánya,

Mielikki, erdő szűze,

Tellervo, Tapio szűze. (NK ${ }^{337}$ )

${ }^{336}$ A forrásszövegben elöforduló személy- és földrajzi neveket, valamint célszövegbeli megfelelőiket lásd a 2. mellékletben.

${ }^{337}$ NK - Nagy Kálmán, BF - Barna Ferdinánd, VB - Vikár Béla, RI - Rácz István, SzI - Szente Imre. 
Barna Ferdinánd csupán az első két sor neveit fordította le magyarra, a megtartott forrásnyelvi szavak írásában azonban nem volt következetes (Tápió - Tápjó):

Nyár tündére, áldott nő te,

Déltündér, természet üke,

Hongatar, jóságos asszony,

Katajatar, szép hajadon,

Pihlajatar, kis leányka,

Tuometar, Tápió lyánya,

Mielikki, erdő neje,

Tellervo, a Tápjó szűze! (BF)

A Suvetarból (suvi = nyár, -tar = nőnévképző) így lesz Nyártündér, az Eteletärből (etelä = dél, -tär = magas hangrendű szavakhoz kapcsolódó nőnévképző) pedig Déltündér. A többiek a Mielikki, Tellervo és Tapio neveknek nem találtak magyar megfelelőt, ezért - a két utolsó fordító Vikár stratégiáját követte - e három kivételével a többi tulajdonnevet fordították magyarra. Így lesz Hongatarból (honka = erdei sudár fenyő) Fenyőszűz, -tündér vagy Tủlevelű tündér, a Katajatarból (kataja = boróka) Boróka, -szűz, -lány, a Pihlajatarból (pihlaja = berkenye) Berkenye, -szűz és a Tuometarból (tuomi = zelnice) Zelnice, -szűz.

Nyártündér, nyájas asszony,

Déltündér, teremtő néne,

Fenyőszűz, te jó gazdasszony,

Borókaszüz, szép kisasszony,

Ici-pici berkenyeszüz

Tapio lánya, zelniceszűz,

Mielikki, erdei menyecske,

Tellervo, Tapio hölgye. (VB)

Nyártündér, te nyájas asszony! Déltündér, derék menyecske!

Fenyőtündér, fák őrzője! Borókalány, bájos gyermek!

Berkenyeszüz, szép szolgáló! Zelnice, zöld erdő lánya!

Mielikki, kis menyasszony! Tellervó, Tapió szűze! (RI)

Nyártündér, aranyos asszony, Dél tündére, táltos asszony, Tülevelü tündér, të drága, bájos barna lány, Boróka, Berkënye, csinos cselédke, Zelnice, Tapio szépe, Mielikki, mézes mënyecske, Tellervo, Tapio lánya (SzI). 
Olyan személyek, mellékszereplők is vannak az eposzban, akiknek a nevét mindenik fordító lefordította: Aallotar (aalto = hab, hullám) - Habtündér (BF), Hableány (VB), haboknak gyermeke (NK), hullámok lányai (RI) vizi tündér $(\mathrm{SzI})$; Kankahatar (kangas = szövet) - Gyolcstündér $(\mathrm{BF})$, szövő leány (NK), szövőasszony (RI) nők (SzI); Kivutar (kipu = fájdalom, kín) - Kórsellő, -tündér (BF), Kórleány (VB), kín tündére (NK) Kór tündére (RI) Kínkisasszony, -anyó (SzI); Kuutar (Kuu = Hold) - Hold tündére $(\mathrm{BF})$, holdtündér (VB), Hold leánya (NK), Holdtündér, -lány (RI), Holdleány (SzI); Luonnotar (luonto = természet) - lég leánya $(\mathrm{BF})$, ég leánya $(\mathrm{VB}$, $\mathrm{NK}$ ) levegőég leánya (RI), egek leánya (SzI); Manalatar (Manala = alvilág) - alvilági öreg asszony (BF), alvilág anyója (SzI); Melatar (mela = kormányevező) - Kormánytündér (BF), Zúgótói kisasszony (VB), Kormányos tündér (SzI); Otavatar (Otava = Göncöl) - Göncöllány (VB), Göncölleány (NK) Göncöl lánya (RI), Ég tündére (SzI); Päivätär (päivä = nap) - Nap tündére $(\mathrm{BF})$, naptündérke (VB), Nap leánya (NK), Napnak szüze (RI), Napkisaszszony (SzI); Sinetär (sini/nen/ = kék) - Kéktündér (BF), festő leány (NK), kékfestő lány (RI), nők (SzI); Suonetar - Erek anyja (VB), érhez értő tündérasszony (SzI); Tähetär (tähti = csillag) - Csillaglány (VB), csillagleány (NK), csillag lánya (RI), Csillagtündér (SzI); Uutar (utu = köd, pára) - Ködtündér $(\mathrm{BF})$, Ködkisasszony (VB, SzI), köd tündére (NK), Köd leánya (RI); Vammatar (vamma = sérülés, seb) - Sérvtündér $(B F)$, Sebleány $(\mathrm{VB})$, seb asszonya (NK), sérv-anyóka (SzI). A lefordított nevek esetében Barna Ferdinánd volt a legkövetkezetesebb: tündérként fordította a -tar képzőt, őt követi Nagy Kálmán, aki vagy a leány vagy pedig az asszony szavakat használta. Vikár Béla, Rácz István és Szente Imre szövegében nagyobb a szórás, több szinonimát is használtak a -tar képző magyarítására.

Ez a stratégia azonban nem érvényesült minden egyes -tar képzővel ellátott tulajdonnévnél. Nagy Kálmán általában megtartotta a forrásnyelvi nevet: Kalevatar, Loviatar, Melatar, Osmotar, Suonetar, Suvetar, Syöjätär; vagy csak a képzőt konkretizálta, szószerkezet esetén pedig a második tagot: Manalatar - manalai asszony, Tuonen tyttö - Tuoni lánya.

Amikor Vikár és Rácz is hasonló stratégiát választottak és megtartották a forrásnyelvi tulajdonnevet, ott a magyar kiejtés szerinti írásmódot alkalmazták. Ez a módszer azt eredményezi például a Kankahatar név esetében, hogy Kankahatár lesz. Vagyis a nőt jelölő név (-tar képző) a -határként értelmezett utótag miatt földrajzi névvé minősül át. Vagy - és ez sokszor Barna Ferdinándra is jellemző - egyszerủen -tár végű lesz, olyan tárgy jelölője, amelyben tartanak valamit: Kalevatár, Loviatár, Melatár, Oszmotár, Szuonetár, Vammatár. Érdekes módon Rácznál a Kivutarból Kiputár lesz, vagyis a finn nyelv grammatikai szabályait figyelembe véve, a tőhangváltást megszüntette $(\mathrm{p}-\mathrm{v})$ és az immár magyarosított -tárt a nominatívuszi 
alakhoz kapcsolta. A magyar kiejtés szerinti írásmód szempontjából meg kell említenünk a Syöjätär nevet is, mely csak Nagy Kálmán és Szente Imre szövegében követte a forrásnyelvi alakot, Vikár Bélánál és Rácz Istvánnál Szüöjeter formában jelent meg. Barna Ferdinánd pedig köztes megoldást választ - Szüöjätär. Az y betút $u ̈$-re cserélte, mivel mindkettő ugyanazt a hangot jelöli, és mivel a magyar nyelv nem jelöli a nyílt $e$-t, meghagyta a finn nyelvi változatot, az $\ddot{a}$-t.

\subsubsection{A -1A és -(1A)inen képzőjű szavak fordítása}

A -la helynévképző országot, földet jelent. Akárcsak a -tar képző esetében, a -la képzőjü szavak fordításában is különféle stratégiáknak lehetünk tanúi.

Kétfajta megoldás a jellemző: a forrásnyelvi szó megtartása vagy magyarosan írása és a konkretizálás. Ahol megtartották a forrásnyelvi alakot, ott többnyire mind az öt fordító egyformán járt el. Például az Ahtola, Joukola, Kalevala, Karjala és Tuonela szavak esetében. A Sariola és Suvantola helyneveket Barna, Vikár és Rácz magyarosan írta: Száriola, Szuvantola.

Majd mindannyian konkretizáláshoz folyamodtak a Hiitola - Hísz (VB), Pokol (RI); Kuutola - Hold laka (BF), Holdföld (VB), Hold országa (NK); Luotola - Luotola öble (BF, NK, RI); Manala - alvilág (BF), Manólak (VB), Mana hajloka (RI); Päivälä - Napföld (VB), Nap országa (NK), Nap háza (RI); Tuonela - Halál-lak (BF) és a Tähtelä - Csillag laka (BF), Csillagrét (VB), Csillag országa (NK), Csillag háza (RI) szavak esetében. A fordítók a -la végü szavak célnyelvi megvalósításaiban többé-kevésbé következetesen jártak el. A valamilyen égitesthez kötődő helynevek konkretizálásában pedig Nagy Kálmán és Rácz István volt az, akik mindig ugyanazt a főnevet használták konkretizáláskor. Barna Ferdinánd érdekes módon nem érvényesítette fordításkiadása jegyzeteinek etimologizálását: Mana = Manó. Megtette ezt helyette Vikár.

A -(lA)inen képző megfelel a magyar - $i$ melléknévképzőnek és valahová valót jelent. A leggyakoribb megoldás a tőhöz illesztett -i, -béli vagy fia, nemzetsége utótaggal jelölés. A Lappalainen, Suomalainen és Viro szavakat pedig lefordították: lapp legény, finn(ek) és Észtország.

\subsubsection{A földrajzi neveket jelölő összetett szavak, szószerkezetek fordítása}

A folyók, tavak, hegyek és dombok neveiben - kevés kivételtől eltekintve - mindegyik fordító konkretizált. A kivételek közé tartozik a Hälläpyörä nevü örvény, melyről csak a két utolsó fordításban derül ki, hogy 
mi is valójában: Halla-örvény (RI) - Hällä-forgatag (SzI), ugyanis a többi célszövegben csak maga a név jelent meg vagy finnesen (NK, BF), vagy pedig magyarosan írva (VB). Ezzel szemben a Kaatrakoski (koski = vízesés) mindegyik fordításban megmaradt eredeti alakjában, Vikárnál egyenesen Kátra-koszkiként jelent meg, vagy pedig sellóvé vált (RI). Ez annál is érdekesebb, mert a forrásszövegben előfordul még egy vízesés, a Rutjan koski, melynek esetében mindegyik fordító konkretizáláshoz folyamodott: Rutja forgója (BF), Rutja zúgója (VB, SzI), rutjai vízesés (NK), Rutja örvénye (RI). Meglepő módon finn nyelvi alakban szerepel a Kaukoniemi is, annak ellenére, hogy egyszerúen fordítható magyarra, a kauko távolit, a niemi pedig földnyelvet, félszigetet, hegyfokot jelent. Egyedül Szente generalizált, ő földnyelvként fordította.

A joki - folyó, mäki - domb és salmi - szoros utótagú szószerkezetek esetében mindannyian konkretizáltak: a Juortanin joki, Kemijoki és Nevan joki így lesz Jordán vize (BF), folyó (NK) vagy egyszerüen Jordán (VB, RI, SzI), Kemi folyó (RI) és völgy (SzI), Néva vize (BF, NK, SzI), folyó (RI) és nagy Néva (VB), a Tapiomäki Tápjó-hegy (BF), Tapio-domb (VB), Tapio hegy (NK), Tápió ólja (RI) és Tapiola (SzI). Az Aluenjärvi (alut vagy alus ${ }^{338}$ = alap, alsó, järvi $=$ tó $)$ és Lemmenlahti $($ lempi $=$ szerelem, lahti $=$ öböl $)$ földrajzi nevek magyarra ültetése a fordítók finn nyelvi kompetenciáját is próbára tette: meg kellett találniuk a nevet adó szó tövét. Gyakorlatilag az összes lehetséges megoldást felvonultatják: Alu (BF), Alut (VB), Alue (NK, SzI). Egyedül Rácz István él a lefordítás lehetőségével, nála Határ-tóként jelent meg. A lempi szó Lemminkäinen, a Kalevala egyik főhőse nevéből is ismert volt, mégis eltérő megoldásokkal találkozunk: Lempi öble (BF), Szépszoros (VB), Gyöngyöböl (NK), Szerelemöböl (RI) és Örömöböl (SzI).

A beszélő földrajzi neveket, mint pl. a Kipumäki (kipu = fájdalom, mäki $=$ domb), Kipuvuori $($ vuori $=$ hegy), Nälkäniemi (nälkä = éhség) mindannyian lefordították: Betegség-domb, Betegség-hegy, éhség-csúcs (BF), Kórságdomb, Kórsághegy, Éhség félszigetje (VB), kórsághegy, bánatdomb, Éhség földje (NK), Kórok köve, Kínok hegye, Éhségfalva (RI), Kínhalom, Fájdalomhegy, Sanyarúfészek (SzI). Nagy Kálmán még azzal érzékeltette beszélő mivoltukat, hogy legtöbbször nem tekintette tulajdonnévnek ezeket.

Amint láttuk, minden célszövegben tapasztalható következetlenség: néhol megtartották a forrásnyelvi alakot, máshol konkretizáltak vagy éppen fordítottak. A különbségek leginkább az arányokban keresendők. A forráskultúrához a nevek fordításának szempontjából Nagy Kálmán áll a legközelebb, az ő szövegében találjuk a legkevesebb lefordított nevet, őt követi a sorban Szente Imre és Barna Ferdinánd. Vikár Béla és Rácz Ist-

\footnotetext{
${ }^{338}$ Olyan szó, melynek alue-töve lenne, a mai finn nyelvben nincs. A régi finnben az alus vagy alut szavaknak lehetett a töve, vagy a lapp alue szónak, mely területet jelent.
} 
ván fordításában pedig a legtöbbet. A célkultúrához tehát az ő fordításaik állnak a legközelebb. Ezt erősítik a le nem fordított nevek magyaros írásmódjával is.

\subsection{Tartalmi különbségek a célszövegekben}

A tartalmi különbségek a tabunak is tekinthető témák nyelvi megformálásában jelentkeznek, a reáliák fordításában és a beillesztett vendégszövegekben.

\subsubsection{Tabutémák}

Az első és az utolsó teljes fordítás megjelenése között több mint 100 év telt el. Olyan tabutémák megjelenítésében, mint az incesztus, zoofília és a paráznaság, valamiféle fokozatosságot feltételezek, mely a 20. század végi fordításokban éri el a teljes konkrétság szintjét. A témákat a Lemminkäinen-epizódban vizsgálom, mivel ebben találjuk a legtöbb és legkonkrétabb utalást a szexualitásra. Az összehasonlításban utalni fogok Vikár Béla 1901ben megjelent $A$ Kalevalából. A Lemminkäjnen-runók címü szövegére is.

\subsubsection{Incesztus}

A Kalevalában több helyen is találkozunk incesztussal, gondoljunk csak Joukahainen vagy Kullervo történetére. Talán ennek a "gyakori” előfordulásnak is tulajdonítható, hogy Barna Ferdinánd már 1871-ben sem eufemizált:

Megcsufolád anyádhoztát,

Tenhugodat elcsábítád. (BF, 12:489-490)

Vikár az 1901-es szövegben csupán a kétsoros gondolatpárhuzamot olvasztotta össze egy sorrá: Meggyaláztad tenfajodat. (1901, 12:489). A teljes szövegkiadásokban azonban már megtartotta mindkét sort és konkrétabban is fogalmazott:

Szüléd szültjét szeplőztetted,

Tenned húgod fertőztetted. (VB, 12:489-490)

- szól Lemminkäinen a „nedvessipkás” csordapásztorhoz, aki később a vesztét okozza. 
A 20. századi fordításokban pedig, ha lehet, még nagyobb fokú a konkretizálás, különösen Nagy Kálmán és Szente Imre szövegében:

anyád véréd megrontottad,

a húgoddal, véle háltál. (NK, 12:489-490)

megrontád szüléd szülöttit, testvérhúgodat teperted. (SzI, 12:489-490)

Rácz István - hűen a vikári hagyományhoz - nemcsak a formai megoldásokban követte elődje stratégiáját, hanem a tematikaiban is. Különösen ami a gondolatpárhuzam második sorát illeti, ahol a hagyományosabb megront igét használta:

anyád lányát letiportad, testvérhúgod megrontottad. (RI, 12:489-490)

\subsubsection{Zoofília}

Ugyancsak a „nedvessipkás” számlájára írandó az incesztus mellett a zoofília is, mely az incesztusnál is súlyosabbnak bizonyul. Erre enged következtetni Barna Ferdinánd megoldása, melyből nehezen lehetne kiolvasni a zoofíliát:

Minden lovat becsunyitál,

csikókat megnyomorítál, (BF, 12:490-492)

Ugyanez Vikár 1901-es szövegében jelentés-összevonással egy sorra redukálódott: Úzted aljas dolgaidat (VB, 12:490). Az 1909-es teljes szövegkiadásban pedig a következőképpen fogalmazott:

A lovakat sorra cseszted,

Kancák kis csikait csekted. (VB - 1909, 12:491-492).

Érdekes módon az 1935-ös kiadásban ez a két sor átmetaforizált, kevésbé konkrét, mint az első kiadásban:

Láttuk ló-lidérc mivoltod,

Kis kancákkal kutyálkodtod. (VB - 1935, 12: 491-492)

A három utolsó fordításban a megront, csúffá tesz, meggyaláz igékkel igyekeztek a fordítók egyértelműbbé tenni a csordapásztor bűnét: 
minden lovat megrontottál,

kanca csikóját csikartad. (NK, 12:491-492)

minden lovat megfertőztél, kis kancákat sem kíméltél (RI, 12:491-492)

csikókat is csúffá tetted, minden kancát meggyalázva.

(SzI, 12:491-492)

\subsubsection{Paráznaság}

Lemminkäinen, a „dévaj fi" a Kalevala szerint nem túl erkölcsös ifjú, szinte egyetlen célja minél több nőnek a meghódítása. Amikor leendő felesége, Kyllikki meghódítására indul, édesanyja figyelmezteti Lemminkäinent, hogy a rangbeli különbségek miatt pórul is járhat, a szári lányok esetleg kinevetik, csúfolódni fognak vele. Lemminkäinen reakcióját anyja intéseire még Barna Ferdinánd fordítása eufemizálta, sőt, el is bizonytalanította az olvasót az „áldozat” kilétét illetően:

A gyereket mellbe nyomom,

Öklöm hónya alatt hagyom. (BF, 11:89-90)

Ez már kevésbé mondható el a többi fordító megfelelő sorairól:

Kicsinyt küldök kebelükbe,

Karonülőt az ölükbe. (VB, 11:89-90).

keblükre gyereket szerzek,

ölükbe ringatni kölyköt; (NK, 11:89-90)

ha kerek hasukba kölyköt, csecsemőt csinálok nékik (RI, 11:89-90)

Babát bujtatok hasukba, ölbevalót az ölükbe (SzI, 11:89-90)

Ugyancsak a metaforizáltság jellemző még Vikár 1901-es változatában is a Lemminkäinennek a szigeten eltöltött napjait elbeszélő részre:

Este lányok körül aggat,

Fürtösfejűeket faggat. (VB -1901, 11:146-147). 
A vizsgált énekekben többször is előfordul olyan sor, amely arról szól, hogy Lemminkäinen nőkkel éjszakázik. Az 1901-es változatból minden ilyen sor kimaradt. ${ }^{339} \mathrm{Ez}$ azért is érdekes, mert például Barna Ferdinánd jóval korábban megjelent fordításában először ugyan kissé homályosan fogalmazott:

Nappal el van a lovakkal

Éjjel aztán a lyányokkal,

Cziczázgatva a szüzekkel,

A szép fürtös fejüekkel. (BF, 11:145-148)

- de pár sorral később nyomát sem látni annak, hogy ez esetleg a tabutémák közé tartozna:

nem volt már ott egy leány is,

Nem bár a legártatlanb is,

A kivel nem szeretkezett,

A kivel nem ölelkezett. (BF, 11:153-156)

Az 1909-es teljes kiadásban már Vikár is jóval konkrétabb volt:

Nem volt ottan lányka olyan,

Sem szúzecske még oly szent se,

Hogy ő hozzájuk ne érjen,

Hogy mellettük ne henyéljen. (VB, 11:153-156)

A három utolsó fordító még tovább ment, és kétséget sem hagytak szövegeikben afelől, mit is tesz, mire is készül Lemminkäinen:

nem is volt leány közöttük,

nem volt szüz olyan szemérmes,

akihez hozzá ne nyúlna,

ne feküdnék oldalához. (NK, 11:153-156)

\footnotetext{
${ }^{339}$ Ebből a kiadásból olyan sorok is kimaradtak, melyek be nem illesztésére nem találtam semmiféle különösebb okot. Ezek a sorok a következők: „maga léha Lemminkäinen,” (12:26), „Szólt a léha Lemminkäjnen,/ Válaszolt a vérmes fickó:/ Van biz itt az ifjú népben,/ Növekedő nemzedékben/ Talpad szöktetni tudója,/ Lábtód sarkkal rugtatója." (13:85-90), „Más Tapio-nép is közte” (14:125), „nyírfákat arany virággal” (14:187), „Új ezüstös csengők közzé.”(14:350), „Ifját kardmarkolatára," (15:232), ,Lel az egyik vállcsontjára," (15:302)
} 
Nem hagyta ő öleletlen még a legszentebb leányt sem, megfeküdte mindegyiket, szeplőssé tett minden szűzet.

(RI, 11:153-156)

egy se volt leány Szigetben, mégha mégoly ájtatoska, hogy ne játszott volna véle, ágyába ne vitte volna. (SzI, 11:153-156)

A vizsgált részekből láthatóvá vált, hogy egy témának tabuként kezelése nem csupán az idők folyamán változik. A témák között is akad erőteljesebben tabuként kezelt. A három közül a paráznaságot tekintették a fordítók a legkevésbé tabunak, és a zoofília tette leginkább visszafogottá még a 20. század végi fordítókat is.

\subsubsection{Reáliák}

Azokat a fogalmakat nevezzük reáliáknak, melyek lefordíthatatlanok a célnyelvre. Két szót választottam a vizsgálat tárgyául: a kantelét és a szaunát. Napjainkban mindkettő ebben az alakban él a magyar nyelvben. Olyan finn nyelvi kölcsönszavakkal van dolgunk, melyek fokozatosan terjedtek el. Ebből kiindulva feltételezhetjük, hogy a Kalevala-fordításokban is fokozatosan jelennek meg: az elsőkben még nem, de a 20. század utolsó harmadában már találkozhatunk velük mint a magyar olvasó számára ismert fogalmakkal.

\subsubsection{A kantele}

A kantele finn népi húros hangszer. A Kalevalában kettőt is készít Väinämöinen: az elsőt egy csuka álkapcsából, a másodikat pedig nyírfából készíti, miután az első elvész a szampó visszaszerzéseért folytatott harcban.

Az első és a második teljes magyar fordítás megjelenésekor a kantele szó és az általa jelölt tárgy nem volt ismert a magyar olvasóközönség előtt. A fordítóknak, Barna Ferdinándnak és Vikár Bélának, tehát két lehetősége volt: használni a kantele szót és konkretizációval magyarázni a jelölt tárgyat vagy analógia alapján a magyar kultúrkörben ismert húros hangszerrel helyettesíteni azt. A fordítók az utóbbi megoldást választották. Barna a koboz és a lant szóval: Lantját legott kézbe vevél(...)/kéz-ügyébe a jó kobzot, Vikár pedig a hárfával, (csont)muzsikával, örömfával és hegedűvel helyettesíti a kantelét: Megvan immár a muzsika, I Ím a hárfa megcsinálva; Ós örömfa hangra hozva./ Készen lett ím hegedúje. Nagy, Rácz és Szente egészen más helyzetben volt, hiszen a 70-es, 80-as években már ismert lehetett a szó 
jelentése a magyar olvasó számára is, különösen a finn népköltészetet kedvelők körében ${ }^{340}$ Mindhárom fordító használta a kantele szót, ugyanakkor, Nagy Kálmán kivételével: halcsontos kantele lenne, éltek a konkretizáció lehetőségével is. Rácz Istvánnál a gondolatpárhuzam második sorában a hárfa mint a kantele szinonimája jelent meg: Bizony kitünő kantelét lehet e csontból csinálni, / ha van, aki tudja titkát, hogy csinálhat halcsont hárfát. Szente Imre pedig a kobozt és a lantot illesztette a gondolatpárhuzam soraiba: Lëhetne pedig belóle csukacsontos kantëlécska, készitóje hogyha volna, csinálója csontkoboznak. vagy Akkor léha Lemminkäinen kantëlét kezébe kapta, öröm hangszërét ölébe, ujjai alá a lantot. A második kantele készítésénél már nem is a kantele került első helyre, hanem a koboz, amit a kantele és a lant szavakkal konkretizált: Akkor Väinölä-nek véne kobozt készítëtt a fábul. Hosszú nyári nap faragta, kantëlécskéjén kopácsolt párás földnyelv hajlatában, szélinél ködös szigetnek. Lantja ládikáját véste, keretët az új koboznak; ládát fája vastagábul, keretët kemény tövébül.

A 20. század végére a kantele már ismert volt a magyar olvasók körében is. A fokozatosság érvényesül a szó használatában: az első fordítások még nem használták, az utolsó háromból pedig csak Nagy Kálmán volt az, aki nem is keresett a célkultúrában a kanteléhez hasonlító hangszert jelölő szót. Rácz és Szente is élhetett volna Nagy Kálmán-i stratégiával. Hogy egyikük sem tette, az éppen a fordítói célkitúzéseikről árul el sokat. Rácznál a hárfa használata mintegy a kantele mellett a megmutatás gesztusát erősíti, Szenténél pedig a koboz előtérbe helyezése a honosítás egyik módjává válik.

\subsubsection{A szauna}

A szauna olyan helyiség van különálló faház a forráskultúrában, melyet forróra fütenek, napjainkban leginkább relaxációra használják szerte a világon. Régen azonban a szaunának többféle funkciója is volt: tisztálkodásra használták, emellett pedig itt szültek a nők vagy itt ápolták a betegeket.

A kanteléhez hasonlóan, bár ma már a magyar kultúrában is jól ismerik, a 19. században kevéssé volt ismert.

Feltételezhetjük tehát, hogy az első fordítók, Barna Ferdinánd és Vikár Béla, körülírással magyarázta vagy analógia alapján a magyar olvasó számára is ismert olyan szóval helyettesítette, mely hasonló funkcióval bíró helyiséget jelöl. Ismét ez utóbbi lehetőséggel éltek. Barna legtöbbször a fürdőt használta, a gondolatpárhuzam második sorában pedig elvétve a

${ }^{340}$ A finn népköltészet lírai dalaiból készült válogatás címe Kanteletar, melyből részletek Bán Aladár fordításában 1902-ben, majd Rácz Istvánéban 1985-ben láttak napvilágot. 
gőzbányát, szauna helyett. Vikár ugyancsak a fürdôt, a paralelizmusban pedig a viskót illesztette fordításába, de emellett találkozunk a gőzlővel vagy a gőzszobával is.

A három utolsó fordítónál már megjelent ugyan a szauna, de mindegyikük használta a fürdôt és valamilyen célkulturális megfelelőt is: Nagy Kálmán a fürdőházat, Rácz István körülírással a forró gőzt, Szente Imre pedig úgyszintén a fürdőházat.

$\mathrm{Az}$ újabb magyar Kalevalák megjelenésének idején a célkultúrában még nem volt annyira elterjedt a szauna, hogy ne kelljen a fordítóknak célkulturális megfelelőt használniuk. Éppen ezért a szauna reália használata csak annyiban érdekes számunkra, a fordítói stratégiák alátámasztására nézve, amennyiben már magának a szónak a megjelenését annak tekintjük.

\subsubsection{A magyar kultúrkörhöz kötődő vendégszövegek a fordításokban}

A legtöbb magyar kultúrkörhöz kötődő vendégszöveg Szente Imre fordításában található. Éppen ezért a következőkben a Szente által használt vendégszövegekkel foglalkozom, a többi fordításra csak utalni fogok.

\subsubsection{Boldogasszony}

A keresztény katolikus hagyományban Boldogasszony maga Szüz Mária, Jézus anyja. A Magyar Katolikus Lexikon a következőképpen határozza meg Boldogasszony fogalmát: „Nagyasszony, Boldogságos Szűz Mária neve a nép ajkán. Történelmünk folyamán lassan a Nagyasszony, ill. a Kisasszony megszólítás helyére lépett. Krisztus anyja nevét ugyanis a magyar nemzet ki nem ejti, hanem csak Úrnőnek mondja, hisz Pannóniát a Boldogságos Szűz családjának nevezte Szent István király". ${ }^{341}$ A Magyar Néprajzi Lexikon pedig a következőképpen: „,feltehetőleg ősi asszonyistenség neve. Gellért püspök tanácsára a térítők Szüz Máriára alkalmazták". ${ }^{342}$ Boldogasszony kettős természetével - valamikori pogány istenségasszony, később a kereszténység egyik fő alakja, Szűz Mária - a fordító is tisztában volt, éppen e kettősség miatt vélite helyénvalónak és a Kalevala szelleméhez illőnek Boldogasszony azonosítását a következő személyekkel:

\footnotetext{
${ }^{341}$ Magyar Katolikus Lexikon 1993.

${ }^{342}$ Magyar Néprajzi Lexikon 1977.
} 


\section{Ilmatárral, minden asszonyok anyjával:}

Így született Väinämöinen, minden énekesek éke Kisboldogasszony-anyátul, istenáldott Ilmatártul. (1:107-110)

Vagyok asszonyoknak anyja, égi nöszemélyek éke, mindenek szüzen szülöje. (47:154-158)

jöjj, Boldogasszony anyácska, teremtés aranyvirága, anyja minden asszonyoknak, ősanyánk, világ szülóje. (17:291-294)

\section{Föld bábájával:}

Föld bábája, Boldogasszony, föld alatt lakó Nagyasszony. (2:301-302)

\section{Erek asszonyával:}

Erek asszonya, Nagyasszony, érhez értő tündérasszony. (15:315-316)

\section{Természet tündérével:}

Természettündér, Nagyasszony, aranyasszony, ékességes, egész nöi nemnek őse, asszonyoknak és anyáknak. (45:116-119)

Ha megvizsgáljuk az említett négy személyiség viszonyhálóját, akkor láthatóvá válik, hogy Ilmatár nem más, mint egek leánya, természettündérek anyja (SzI 47:141-142), vagyis természettündéré, Erekasszonyáé és a Kalevalában fellelhető összes tündéré/asszonyé/szűzé: a Ködé, a Homályé, a Nyáré, a Délé stb. Ez pedig következetlenné és logikátlanná teszi a pogány eredetre utaló használatot a szövegen belül.

Ha Lönnrot intencióit is bevonjuk a vizsgálatba, akkor azt látjuk, hogy Lönnrot az eposz összeszerkesztésekor, történelmi interpretációs elvekből kiindulva végig arra törekedett, hogy a keresztyén elemeket, utalásokat ne emelje be a mübe. Vannak ugyan kivételek, ilyen a tulajdon- és földrajzi nevekben előforduló Ruotus és Juortanin joki vagyis Heródes és a Jordán folyó, valamint az ötvenedik ének Marjatta-epizódja, melyben nyilvánvaló az utalás Krisztus születésére. De Lönnrot elképzelésébe, hogy az eposszal a finn történelmet írja le, a kereszténység felvételének ábrázolása is hozzátartozott. A folytonosság érzékeltetéséhez mindezek nagyon jól illettek. A szentei fordításban az ellentmondás így is értelmezhető: a Szüz Máriára asszociáló nagy/kisboldogasszony használata a szövegben végig, az utolsó 
ének Marjatta-epizódját kérdőjelezi meg. Marjatta, szűz leány, ugyanis csodálatos módon egy erdei bogyótól esik teherbe. Terhessége alatt mindenki kiközösíti, ezért kénytelen gyermekét egy lóistállóban megszülni. A gyermek megszületése után a közösség a kisded életére tör, de végül mégis ő lesz az, aki átveszi Väinämöinentől a hatalmat, Kaleva népének vezetője lesz. Lönnrot ezt a hatalomváltást - a bogyótól megfogamzott gyermek és a Szent Lélektől fogant Jézus analógia alapján - a finn történelemben a kereszténység felvételekor bekövetkezett váltással azonosította.

\subsubsection{Ukko, „Miatyánk magas egekben”}

Az Úr imádságából kölcsönzött szószerkezetet Mi Atyánk, a fordításban egybeírva: Egeknek ura, nagy Ukko, Miatyánk a mënny-egekben (2:317), olyannyira a keresztény hagyományokhoz kötődik, hogy a pogány-keresztény egyensúly eltolódni látszik a keresztény felé. Különösen, ha ezt a Boldogasszony név használata is erősíti. A többi, a keresztény és pogány fogalomrendszer által egyaránt használt elemet - Ukko összekapcsolása az egekkel, felhőkkel - kitűnően érvényesítette Szente: Világnak Ura, nagy Ukko, istene magas egeknek (9:33-34), Világnak Ura, nagy Ukko, egekben időzó isten! (9:403-404), Világnak Ura, nagy Ukko, fellegek fölül beszéló (12:281-282). Ugyancsak ez mondható el Ukko Istennel, Teremtővel való azonosításáról: pl. Boldog Isten böven adjon, Teremtő tetézve merjen... (21:429-430). Az Istennel - Rácz Istvánt kivéve kis betüvel írva - vagy a teremtôvel azonosítás az Urammal együtt a többi fordítónál is megjelent.

\subsubsection{Csodaszarvas, turul és Óperencia}

Szente fordítói múhelytanulmánya, a fordításkiadások elő- és utószói arról tanúskodnak, hogy ezen vendégszövegek használata a fordításban egyszerre ösztönös és tudatos. Ösztönös, amint az idegenben a sajátra való ráismerés vezérli és tudatos, amint a magyar néphagyományban az analógiákat keresi.

Így válik csodaszarvassá a szarvasüzés analógiája alapján Hiisi, a pokol szarvasa:

(Hiisi népek:) szarvasukhoz így beszéltek, rénjüket tanítva rosszra: szaladj, szarvasa pokolnak, csodaszarvas szedd a csülköd, rének ellető helyére, lappföldi fiak honába! (SzI 13:119-124).

Hiisi szarvasa a többi fordítónál: derék állat $(\mathrm{BF})$, nemes állat (VB, $\mathrm{NK})$ vagy egyszerüen csak szarvasom, rénem (RI). 
A nagy testü, bűvös madár szintén analógia alapján lesz turulmadárrá. A mühelytanulmány alapján nehezen lehet eldönteni, hogy Szente a turul szót mitikus vagy referenciális értelemben használta-e. A fordítás alapján:

most hát Ilmarinen mester tüzes, táltos sast kovácsolt, (...) Táltosmadarát tanítva, szólt hatalmas szárnyasához: Táltosom, turulmadaram...(SzI 19:185-186,194-196)

- a mitikus jelentés tűnik valószínűbbnek. A fordító azonban a referenciális jelentés mellet foglalt állást. Meglátásában joggal nevezte turulnak, hiszen a szó maga török eredetű közönséges madárnév, mint a karvaly. ${ }^{343}$ Vikár Béla ugyancsak így nevezte a madarat szép turulom, gyöngymadaram (VB 19:195-196). Nagy Kálmán griffmadárnak, Rácz István sasmadárnak, de egyszer turulnak is.

A szarvasűzésben megjelenő Óperencia szót többen sem találták helyénvalónak Szente kritikusai közül az etimológiája miatt: az ober Enns szószerkezetre vezethetô vissza. Az ugyanebben a sorban megjelenő Ungon-berken (Ungon-berken hajt utána, Operenciát bejárja; SzI 13:149-150) etimológiai szempontból éppúgy kifogásolható lehetne, hiszen Ung és Bereg egykori magyar vármegyék nevéből ered. Az Óperencia mint a magyar népmesék szinte állandó fogalma nagyon is megfelelt a szentei honosító stratégiának.

\subsection{A forrás- és célnyelvi szövegek összevetése ${ }^{344}$}

A célszövegeknek a forrásszöveggel való összehasonlító vizsgálata kiemelt nézőpontok szerint történik: a fordítói stratégiákon alapuló pozitív vagy negatív természetű kapcsolatok vizsgálatán keresztül. Az első két Kalevala-fordítás esetében például az a törekvés, hogy a finnugor hálót megteremtsék, ilyen kiindulópont lehet. A forrás- és célnyelvi szövegek összehasonlító vizsgálatára nehéz volt kiválasztani a megfelelő szövegrészt. Választásom végül azokra a szövegrészekre esett, melyek kitüntetett helyet foglalnak el a Kalevalában: az elő- és utóhangra. A kiemelt helyet egyes kiadások külön is jelölték: sokszor csillaggal választották el az első és az utolsó runó többi részétől, de az is előfordul, hogy külön cím alatt találhatóak. Ami a forrásszöveget illeti, mindkettő része a runóknak, és a

\footnotetext{
${ }^{343}$ SZENTE 2003: 116.

${ }^{344}$ A vizsgálatot képező elő- és utóhang finn nyelvű teljes szövegét és magyar fordításait lásd a 3. mellékletben.
} 
bevezető tartalmi összefoglalásban jelezte Lönnrot, hogy bevezetö- és zárórészről van szó: Runo aloitteleikse és Loppuruno címekkel utalva erre.

Azt vizsgálom a következőkben, hogy milyen fordítói olvasat rajzolódik ki a célszövegekből a Kalevala mint eredettörténetet illetően, mennyire foglal el központi helyet a nemzedékről nemzedékre hagyományozódás, valamint azt, hogy a népies vonásokat milyen eszközökkel valósítják meg a fordítók.

\subsubsection{Az elő- és utóhang}

Amint már említettem, a szövegválasztást az elő- és utóhang eposzban elfoglalt kiemelt helyzete indokolta. A kettő közé, mintegy keretbe ékelődik maga a történet. Mindkettő a dalos történethez való viszonyáról, származásáról szól. Az előhang tulajdonképpen összefoglalva tartalmazza mindazt, amit a szerkesztő Lönnrot elgondolt összegyúittött anyaga kapcsán. „A dalos előszava” című népi éneket a homéroszi eposzok analógiájára illesztette a Kalevalába. ${ }^{345}$

Az eposzi előhang az éneklésre való rákészülésről szól, arról a pillanatról, amikor a dalos társat keres az énekléshez. Örömteli rákészülés ez, annak ellenére, hogy már itt felbukkan a nyomorúságos, puszta északi táj képe. A finn eposzban nem találunk olyasfajta hősi harcokat, mint a homéroszi eposzokban. A Kalevala a szó hatalmáról, varázserejéről mesél.

Már az első sor tekee mieli 'kedve támad' szószerkezete örömteliséget sugall. Nagy Kálmánt kivéve mindegyik fordítónál ez szerepelt az első sorban:

Mind csak azon gondolkom, egyre azon elmélkedem (NK)

A közöttük levő különbség egy-egy utalószó, határozószó betoldásából adódik és az alliterációk mennyiségéből:

Mostan kedvem kerekedik,

Elmém azon töprenkedik. (VB)

Imhol kedvem kerekedett, eszemben gondolat gerjedt (RI)

Kerekedik arra kedvem, mind azt forgatom fejemben (SzI)

${ }^{345}$ Vö. KAUKONEN 1983: 74. 
Barna Ferdinánd az örömteliséget másként fejezte ki:

Hajt a lélek, nagy a kedvem,

Gondolatom unszol engem.

Alliterációk tekintetében - a fordítói és kritikai normákkal foglalkozó fejezet előfeltevéseit alátámasztva - Rácz és Szente járt elől. A finn szövegben a minun birtokos esetü személyes névmás is megjelenik. Magyarul részeshatározó esetben levő személyes névmás alkalmazása lenne természetes: nekem kedvem támad. Nagy Kálmán az ént tette grammatikai áthelyezéssel rejtett alannyá: gondolkodom. Ennek az igének a használatával ugyan elvész valami az éneklésre való készülődés örömteliségéből, de a grammatikai cserével - a kedvem támad szószerkezet csak a harmadik sorban jelenik meg - természetesebb átmenetet sikerült teremtenie a következő sorok főnévi igeneveihez:

Kedvem támadt énekelni, jó szívvel beszédbe fogni, népünk versét mondogatni, régiek dalát dalolni. (NK)

A finn nyelvben a főnévi igenévnek több formája is van. Átmeneti szófajként kifejezhet akár cselekvést is, és a hozzá kapcsolt birtokos személyjelen keresztül utalhat a személyre, esetünkben lähteäni, saa'ani, ahol a -ni első személyű birtokos személyjel. A finn nyelvben gyakran használt főnévi igeneves forma a 3. infinitívusz, melyhez helyhatározóragok kapcsolódhatnak: laulamahan, suoltamahan, sanelemahan. Ezt az alakot magyarra főnévi igenévvel lehet fordítani, ahogyan Vikár, Nagy, Rácz és Szente teszi: énekelni, dudolni, fujni (VB), énekelni, mondogatni, dalolni (NK), énekelni, mondani, regélni (RI), énekelni, dalolni (SzI), vagy a személyjeles főnévi igenévvel: "fognom dalhoz, énekléshez", „kezdenem a regéléshez" (BF).

A finn nyelvnek a magyarnál szintetikusabb jellegére mutat a birtokos személyjellel ellátott passzívumos particípium partitívuszos (részelő esetben levő) formája. Ezzel egy időhatározós mellékmondatot lehet gyakorlatilag egyetlen szóba - az igébe süríteni: yhtehen yhyttyämme = sen jälkeen kun yhyimme yhtehen (az után, hogy mi összegyưlttünk); kahta'alta käytyämme = sen jälkeen kun me kävimme kahta'alta (az után, hogy mi kétfelől jöttünk). Szente Imre határozói igenévvel tartotta meg a finn szöveg sürített szerkesztésmódját:

együttlétre egybegyúlve, kétfelől közel kerülve. (SzI) 
A többiek grammatikai felbontáshoz folyamodtak: a kifejtett mellékmondatos formát használták. Barna Ferdinánd fordítása a legpontosabb, ami a grammatikai felbontást illeti:

Miután most összejutánk,

Szerte hosszan jártunk után. (BF)

Vikár Béla és Nagy Kálmán a most határozószóval egyidejüséget feltételezett a fö- és mellékmondat között:

Most hogy újra összejöttünk,

Két felől ide kerültünk. (VB)

mert most megint összegyültünk, megérkeztünk messze földről. (NK)

A forrásnyelvben az egyidejüség kifejezésére a particípiumos forma helyett egy 2. infinitívuszos formát találunk: yhyessämme és käy'essämme. Ez az egyidejüség azonban egyáltalán nem zavaró a célszövegekben. Sőt, sokkal inkább alkalmas az időtlenség kifejezésére.

A szóhasználat terén Vikárnál már itt tetten érhető az archaikus és népnyelvi szavak használata. Barna 1871-es fordításában is megtalálható a korács szó, Vikárnál ezt a játom szó ${ }^{346}$ előzi meg, ami Barnánál játszó-társ. Erre utalhatttak Nagy Kálmán és Vikár kritikusai is, amikor az avítt szóhasználatot kifogásolták. Nagy hű maradt fordítói elveihez, miszerint ő egyszerü, köznyelven írt Kalevalát kívánt az olvasók elé tenni. Fordításában a veikkoseni és kasvinkumppalini az 1970-es évek köznyelvének megfelelő jó barátom és gyermekkori társam. Rácz István a hü pajtásom mellett a hangulatában archaikusabb vélem serdült vérem szószerkezetet is használta. Szente Imre ugyanígy járt el: fivérem és vélem ëgyivású vérëm.

Ugyancsak a problémás szavak sorába tartoznak a sukuvirttä 'nemzetség, törzs, atyafiság, család + ének, dal' és lajivirttä 'faj, fajta, osztály + ének, dal'. Az öt fordításban más-más megoldást találunk. Barna Ferdinánd nagy valószínűséggel félreérthette a lajivirttä laulamahan sort, s így válhatott belőle hadak sorát levezetnem. A gondolatritmus következő (vagyis az előző) sora azonban megfelelő: nemzetségdalt énekelnem. Vikár fordításában a két sor:

${ }^{346}$ A 2007-es szemelvényes kiadásban Voigt Vilmos a válogatás mellett szövegjavításokat is végzett. A Vikár által használt játom és korácsom szavakat társamra és pajtásomra cserélte. Ezenkívül szórendbeli javításokat eszközölt és a hosszú-rövid magánhangzókat napjaink helyesírásához igazította. 
Nemek nótáit dudolni,

Fajok énekeit fujni.

Nagy Kálmán az 1960-as és az azt követő évtizedek Romániájának talán leggyakrabban használt szavát iktatta be:

népünk versét mondogatni,

régiek dalát dalolni.

Gáspár Sándor, már említett 1977-es tanulmányában, ezt a megoldást kiemelten jónak tartotta. Rácz és Szente megoldása „eposzibb” hangulatot teremtett az eddigieknél. A nemzetség, nemek és nép dalai, éneke és nótái helyett jelentésfelcseréléssel az ôsi mondák, régi regék (RI) vagy a régvalók és ôsi dolgok (SzI) szószerkezetek használata az eredettörténet megkívánta ősiséget húzza alá.

A folytatásban az éneklés rituáléjának lehetünk tanúi, ahogyan egymással szemben, egymás kezét fogva, egymás történetébe kapcsolódva kezdenek a történetmesélésbe.

Honnan származik az ének és a történet? Erről szólnak a következő sorok. Az ige és a hozzá kapcsolódó vonzat megválasztása a különböző fordítói olvasatokról árulkodik: a hősök teremtette történetről és a történet teremtette hősőkről egyarán tszó esik a magyar szövegekben. Nagy Kálmán szót szerez, verset vesz valamin, majd a szereplők teremtette történetre fókuszált. Barna Ferdinánd, Rácz István és Szente Imre bemutatta, miről és kiről is szól az ének, majd ezzel összhangban a történet teremti saját hőseit.

Rácz és Szente szövegében az egyik gondolatpárhuzam felcserélödik, de éppen a paralelizmus sajátosságából fakadóan ez a szöveg egésze szempontjából lényegtelen. Mindkét fordító többször is élt ezzel a lehetőséggel.

Vikár Béla pedig köztes megoldáshoz folyamodottk: ő is verset vesz, szót szerez, így a történet eredeteként és a valakiről/valamiről éneklésként egyaránt értelmezhetőek a sorai, majd a következő szereplőbemutatásnál Nagy Kálmánhoz hasonlóan a szereplők maguk lesznek a történet teremtői. A forrásszöveg -lta ablatívuszi ragja a történet teremtette hősök értelmezést húzza alá. Hiszen ha valamiről, valakiről szólna, akkor -sta elatívuszi rag szerepelne.

A továbbiakban újra felbukkan a nyomorúságos északi táj képe, azonban csak Szente Imre használt negatív töltetü melléknevet: kopár. Rácz Istvánnál kies a táj, Nagy Kálmánnál messzi a föld, a többieknél pedig egy semleges értelmű főnév fordul elő melléknév nélkül: mező, térség, rét. 
A nemzedékről nemzedékre hagyományozódás érzékeltetésére Szente Imre a Barna Ferdinándéhoz hasonló megoldást választott, az iperedó melléknévi igenévvel egy kis archaizmust is csempészve a szövegbe: $a$ növekvő ifjúságban, fejledezó ivadékban (BF) - iperedó ifjúságot, növekedő nemzedéket (SzI). A mindenki által ismert történet továbbélése csak így valósítható meg: ha hallják és az újabb nemzedéknek is megtanítják. Rácz Istvánnál kissé erőltetett az alliteráció, olyan érzést kelt az olvasóban, mintha a szóválasztását felülírná az alliterációra való törekvés: serdülók serény serege.

A hagyományozódáson, a nemzedékről nemzedékre öröklődésen túl mindig újabb és újabb történetek "teremhetnek" a dalos számára: a természet adja át, ajánlja fel „termését”. Ebben a részben az igék helye szabja meg a fordítások egymástól különböző ritmusát. A forrásszövegben egy particípiumos alakot találunk, az ún. agenttipartisiippi alakot, a sorok végén:

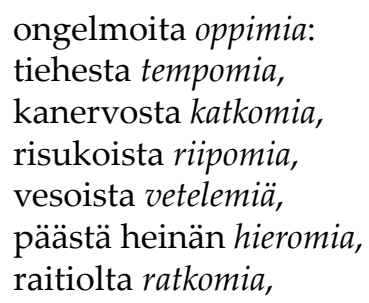

Ennek a particípiumos alaknak általában az a jellemzője, hogy aktívumos alak, és egy olyan cselekvő/ágens kapcsolható hozzá, mely genitívuszban áll. Ebben a részben azonban nincs genitívuszos alak, nincs ágens, nem tudjuk, ki végzi a cselekvést, vagyis ez a forma a személytelenítés eszközévé válik. Magyarul grammatikai felbontással fordítható, ha jelen van az ágens, az általa végzett cselekvésre utalva. Ágens hiányában múlt idejü melléknévi igenév merülhet fel lehetőségként. Érdekes módon a fordítók egyike sem élt ezzel a lehetőséggel. Barna Ferdinándot kivéve a magyar szövegekben csak múlt idejü, első személyű igéket találunk. Barna a múlt idejü formát határozói igenévvel váltogatta, valamint az ige helye is változik, megtörve ezzel a szöveg ritmusát:

Tépegetve az utfélről,

Szaggatva a hangafüröl,

Bokrokrúl is tépegettem,

Fák gallyáról tördelgettem,

Dörzsölgettem füfejekről,

Felszedtem az utszélekről. 
Rácz István és Szente Imre végig megtartotta a főnév + ige szerkezetet, az emiatt kissé monotonná váló szöveget az alliterációk teszik dinamikusabbá:

útak szélén szedegettem, hanga közül húzogattam, bozótokból bontogattam, cserjésekből csipegettem,

füvek fejéből fosztottam, keréknyomról kerítettem (RI)

gyalogúton gyưjtögettem, hangafü közül halásztam, csalitosbul cserkészgettem, bozotosbul bontogattam, fükalászrul fejtegettem (SzI).

A másik két fordítás dinamizmusát az ige helyének megváltoztatása biztosítja. Nagy Kálmánnál az ige akkor került át a sor elejéről a végére, amikor gyakorító igére vált át:

szakitottam útnak szélén, téptem hangafüves téren, bokor-ágról bontogattam, hajló vesszőn hajtogattam, fü fejéről fejtegettem.

Ugyanakkor igyekezett a helyhatározó-állítmány alliteráló párost érvényesíteni. Csak a negyedik sorban alliterál az állítmány a helyhatározó jelzőjével. Vikár szövegében a helyhatározó és a hozzá kapcsolódó jelző vagy a jelző-állítmány párosa alliterál, és - hủen a fordító által is felvállalt elvekhez - a sorvégi rím működik szövegszervezőként, az ige is ezért került az utolsó gondolatpárhuzamban a sor végére:

Téptem őket útmentiben,

Szakítottam hangás helyen,

Tördeltem a törpe fákról,

Gyüjtöttem a gyönge ágról,

Füszálakról leszemeltem,

Falunk útján fölemeltem.

A fentebbi részt bevezető sorokban Szente és Rácz az archaikusabb vettem és szereztem igéket használták, mellyel csatlakoztak a vikári és Nagy Kálmán-i olvasathoz, miszerint a történet teremti a hősöket. Az említett helyen Vikár egy magyarul meglehetősen idegenül hangzó szerkezetet használt: több tanultam büvmondás is, mely a tanultam melléknévi igenév és a gondolatpárhuzam előző sorában megjelenő vannak összekapcsolása 
miatt kelt idegen hatást. Ez egy olyan szerkezet, amely miatt - 1890-es mühelytanulmányában - éppen Barnát bírálta nagyon is keményen.

A folytatásban, a növények mellett, a természeti jelenségek is kiveszik részüket a történetteremtésből, a dalszerzésből. A részletből kikerekedő dal és dalos viszonya a már korábban elmondottakat egészíti ki: nemcsak a fagy, a szél, a tenger megénekléséről van itt szó, a természet nem csupán ihletforrásként (Barna Ferdinánd és Szente Imre) vagy tanítóként (Rácz István) működik közre, hanem akár teremtőként (Vikár Béla és Nagy Kálmán) is:

Dalt sugalt a fagy is nekem,

Dal hult alá az esőben,

Másokat a szelek hoztak,

Tengerhabok azt hajtottak,

A madárkák gazdagíták,

Fák teteji gyarapíták. (BF)

Fagy csípése dalt fakasztott, ritmusra dobolt a zápor; más zenéje volt a szélnek, hangja más futó haboknak, szó lett szárnyak lebbenése, monda lombok moccanása. (SzI)

Téli hideg is tanított, zúgó zápor nótát zengett, szellő szárnyas szókat súgott, hullám habja dallal zúgott, füsti fecske is ficsergett, vén fenyő fújt vidám verset. (RI)

Rácz Istvánnál a játékosságot szolgálni akaró vendégszöveg - Móra Ferenc Zengő ábécéjéből - megtöri a ritmust, és magas hangrendjével is kiugrik a szövegből.

Nagy Kálmán megoldását a többi fordítás viszonylatában a legsikerültebbnek tartom:

Dalaimat fagy dalolta, versemet eső üzente.

Hozta hozzám szél a verset,

hajtogatta tenger habja;

a madár is mondogatta, fák levele fújdogálta. (NK) 
Az alliterációk természetessége, a mély és magas magánhangzók arányának kiegyensúlyozottsága, a gyakorító igék használata olyan játékosságot biztosít ezeknek a soroknak, mely az éneklés örömteliségét húzza alá. Az eposzkezdő sorok ismeretében akár kompenzációnak is tekinthető.

Nagy közvetlen elődjéhez hasonlóan értelmezte ezt a részt. Vikár szövegében azonban a rímre való törekvés itt nem más, mint rímkényszer különösen a második paralelizmusban:

Dalt nékem a fagy is mondott,

Éneket az eső ontott,

Más dalaim szél terelé,

tenger habja hozta elé,

A madár is szókat szerzett,

Fák teteje varázsverset. (VB)

A megszerzett, megteremtett dal birtokba vétele, megmutatása és az elraktározás egy későbbi mozzanata vagy újra elrejtése az elő- és utóhangban a költői képek szintjén szorosan összekapcsolódik. Az alábbi táblázat ezeket a mozzanatokat ragadja meg:

\begin{tabular}{|c|c|c|c|c|}
\hline A dal & birtokba vétele & megmutatása & elraktározása & \\
\hline & $\begin{array}{l}\text { Göngyölegbe kötöz- } \\
\text { getém }\end{array}$ & $\begin{array}{l}\text { Felbontsam-e a } \\
\text { nyalábot, } \\
\text { Felbontsam-e rajt' a } \\
\text { csomót? }\end{array}$ & $\begin{array}{l}\text { Dalaimat egy } \\
\text { tekercsbe, Göngyölegbe } \\
\text { kötözöm be }\end{array}$ & $\overline{B F}$ \\
\hline & $\begin{array}{l}\text { Göngyölítém egy } \\
\text { gumóba, } \\
\text { Csavarítám egy } \\
\text { csomóba }\end{array}$ & $\begin{array}{l}\text { Fölfejtsem-e gumóm } \\
\text { bokrát, } \\
\text { Megoldjam-e } \\
\text { csomóm csokrát? }\end{array}$ & $\begin{array}{l}\text { Gombolyagba } \\
\text { kötöm kótám, } \\
\text { Csomóba csavarom } \\
\text { nótám }\end{array}$ & VB \\
\hline & $\begin{array}{l}\text { Egy csomóba csom- } \\
\text { bolygattam, } \\
\text { gombolyagba gom- } \\
\text { bolygattam }\end{array}$ & $\begin{array}{l}\text { bontsam ének } \\
\text { gombolyagját, } \\
\text { megoldjam-e a } \\
\text { csomóját? }\end{array}$ & $\begin{array}{l}\text { versemet } \\
\text { csomóba gyúitöm, } \\
\text { gombolyagba } \\
\text { gombolyítom }\end{array}$ & NK \\
\hline & $\begin{array}{l}\text { Mind a szót fonálra } \\
\text { füztem, gombolyagba } \\
\text { göngyölgettem }\end{array}$ & $\begin{array}{l}\text { gurítsam ki gombo- } \\
\text { lyagom, bontsam fel } \\
\text { fonalam bogját? }\end{array}$ & $\begin{array}{l}\text { Versem fonalát fel- } \\
\text { szedem, gombolyagba } \\
\text { göngyölítem. }\end{array}$ & RI \\
\hline & $\begin{array}{l}\text { Kincsem kévébe kö- } \\
\text { töttem, gombolyagba } \\
\text { göngyölgettem }\end{array}$ & $\begin{array}{l}\text { Oldjam-é bogát } \\
\text { batyumnak, csoma- } \\
\text { gom csomós kötésit? }\end{array}$ & $\begin{array}{l}\text { Versem göngyöleg- } \\
\text { be gyüjtöm, gombo- } \\
\text { lyagba gombolyítva }\end{array}$ & SzI \\
\hline \multirow{2}{*}{$\begin{array}{l}\text { A dal } \\
\text { helye }\end{array}$} & Ahová & Ahonnan & Ahová & \\
\hline & Betevém ott rézládába & $\begin{array}{l}\text { Dalszekrényem kinyis- } \\
\text { sam-e, } \\
\text { Verses ládám feltárjam-e? }\end{array}$ & $\begin{array}{l}\text { Csontládám } \\
\text { legbelsejébe }\end{array}$ & BF \\
\hline
\end{tabular}




\begin{tabular}{|c|c|c|c|c|}
\hline & Rejtettem a rézvékába & $\begin{array}{l}\text { Föltárjam-e dallos } \\
\text { táskám, } \\
\text { Kinyissam-e verses } \\
\text { ládám }\end{array}$ & $\begin{array}{l}\text { Csontkamra mögé } \\
\text { lecsukom }\end{array}$ & VB \\
\hline & rézládába rejtegettem & $\begin{array}{l}\text { dalos ládám megnyissam-e, } \\
\text { öntsem-e ki verses } \\
\text { vékám }\end{array}$ & $\begin{array}{l}\text { csontos zárakkal } \\
\text { bezárom }\end{array}$ & NK \\
\hline & $\begin{array}{l}\text { rezes ládámba } \\
\text { rejtettem }\end{array}$ & $\begin{array}{l}\text { Nyissam kedves kin- } \\
\text { csesládám, tárjam fel } \\
\text { tarka tetejét }\end{array}$ & $\begin{array}{l}\text { csontos záram mögé } \\
\text { csukom }\end{array}$ & RI \\
\hline & $\begin{array}{l}\text { Rézládámba } \\
\text { rekkentettem }\end{array}$ & $\begin{array}{l}\text { Nyissam szekrényét sza- } \\
\text { vaknak, kincses ládáját } \\
\text { daloknak? }\end{array}$ & $\begin{array}{l}\text { Csontlakat mögé } \\
\text { becsukva }\end{array}$ & SzI \\
\hline \multirow[t]{6}{*}{ A rejtek } & Ahová & - & Ahová & \\
\hline & $\begin{array}{l}\text { Onnan a csür } \\
\text { údarára }\end{array}$ & & $\begin{array}{l}\text { Teszem kamrám } \\
\text { rejtekébe }\end{array}$ & $\overline{\mathrm{BF}}$ \\
\hline & $\begin{array}{l}\text { El is tettem } \\
\text { csürhéjába }\end{array}$ & & $\begin{array}{l}\text { Csomót csür hijába } \\
\text { dugom }\end{array}$ & VB \\
\hline & $\begin{array}{l}\text { kamra padlására } \\
\text { tettem }\end{array}$ & & $\begin{array}{l}\text { kamra padlására } \\
\text { küldöm }\end{array}$ & NK \\
\hline & csür teteje alá tettem & & $\begin{array}{l}\text { kiviszem kicsi } \\
\text { kamrámba }\end{array}$ & RI \\
\hline & $\begin{array}{l}\text { szárító padomra } \\
\text { szórtam }\end{array}$ & & rakom pajta padlására & SzI \\
\hline
\end{tabular}

A táblázatból kiolvasható, milyen mértékben törekedtek következetességre a fordítók. A szövegek tanúsága szerint Nagy Kálmán és Rácz István a legkövetkezetesebb: csomó és gombolyag Nagynál, fonál és gombolyag Rácznál. A legkövetkezetlenebb pedig Barna Ferdinánd - a göngyöleg, a nyaláb és a csomó váltakozva jelenik meg, valamint Szente Imre, aki a kévét és a gombolyagot a boggal, kötéssel és göngyöleggel váltakoztatta. Vikár Béla valahol a kettő között helyezkedik el: a dal megmutatásánál a birtokba vételkor is használt gumó és csomó jelenik meg, csak az elraktározás pillanatában váltja fel a gumót a gombolyag. ${ }^{347}$ A forrásszöveggel való összevetésből pedig az derül ki, hogy a finn szöveg sem következetes a dal birtokba vételének, megmutatásának majd újbóli elraktározásának képi leírásakor. A kerä 'gombolyag' és sommelo 'csomó' az előhangban fordul elő, az utóhang már csak az előbbit használja. Ami a rejteket illeti, ugyanazt a parven pää 'csür, szárítópad eleje' szószerkezetet találjuk mindkét részben, a célszövegek - a Vikár- és Nagy-szövegek kivételével - lemondanak a következetességről.

\footnotetext{
${ }^{347}$ A 2007-es szemelvényes kiadásban erre a következetlenségre Voigt Vilmos is felfigyelt, igyekezett is ezt kigyomlálni, és már az első sorokban a gombolyaggal cserélte fel a gumó szót.
} 
A csontládába (BF) vagy éppen -kamrába (VB), esetleg csontzárral (NK, RI) vagy -lakattal (SzI) lezárt dal utóhangbeli újbóli megszólaltatása négy sorban a dal és a dalos viszonyáról árul el sokat. A paralelizmus hangsúlyozására Rácz Istvánt kivéve -

csak ha csontzáram kinyitom, torkom tágasra kitárom,

fogaim sorát felbontom, makacs nyelvem megmozdítom. (RI)

- mindenki hasonló szerkezetet használt. Vikár és Szente szövegében a nélkül névutó ismétlődik, Nagy Kálmánnál pedig a míg kötőszó:

Csontom megrendülte nélkül,

Állam szétterülte nélkül,

Fogam forgatása nélkül,

Nyelvem nyargalása nélkül. (VB)

csontok csattogása nélkül, állkapcák kopása nélkül, fogak futtatása nélkül, nyelvnek nyargalása nélkül. (SzI)

míg a csontom meg nem indul,

míg az állam meg nem mozdul,

míg a fogam ki nem fordul,

míg a nyelvem meg nem perdül. (NK)

Ami mindannyiuknál közös, az a párhuzamos mondatszerkesztés: birtokos személyjelű főnév + első személyű ige (RI), birtokos személyjelü főnév + főnevesült ige + névutó (VB, SzI), kötőszó + birtokos személyjelü főnév + igekötő + tagadószó + ige (NK).

Barna Ferdinándnál a névutós és a kötőszós szerkezet egyaránt megtalálható. A negyedik sorban azonban mindkettőtől eltért:

A csontnak megingta nélkül,

Államnak szétnyilta nélkül,

Míg fogaim szét nem válnak,

Nyelvem át a gáton nem hat. (BF)

A célszövegekben rendkívül erőteljes a személyre való utalás vagy a főnévhez kapcsolt birtokos személyjel, vagy pedig a rejtett alany, az ige első személyű formája révén. Ez alól egyedül az utolsó Kalevala-fordítás a kivétel, valamint - az első sor erejéig - Barna Ferdinándé. Szente ugyanis nem használt semmilyen nyelvtani formát, mely személyre utalna. Ez a 
személytelenség - a főnevek birtokos személyjel nélküli egyes vagy többes számú genitívuszának használata - a forrásszövegre is jellemző:

ilman luien lonsumatta, leukojen leveämättä, hammasten hajoamatta, kielen keikkelehtämättä.

A forrásszöveg az ismétlődő sorvégi 3. infinitívusz abesszívuszi formájával - melynek jelentése 'ige + nélkül' - is utal a paralelizmusra, a négy sor összetartozására.

Az előzőek ismeretében a dal és a dalos kapcsolata tehát kétféle lehet: a forrásszövegben és Szente Imrénél a dal irányítja a dalost, a többi célszövegben pedig a dalos az, aki irányítja a dalt, annak megszólalását.

De milyen is ez a megszerzett, megtanult dal?

Barna Ferdinánd és Nagy Kálmán megoldásában egyszerűen jó, mely melléknév a dal eredetéből kiindulva túlságosan is súlytalan. Szenténél szebbnél szebb, Rácznál ékes vers, Vikár Bélánál pedig az énekelt történet a dalok legjava:

Dalaink javára gyujtsunk,

Legis-legszépiből nyújtsunk.

A paralelizmus második sorában az igeválasztás nem a legszerencsésebb, mivel az ige tárgyat kíván, ami nincs, ezért befejezetlennek hat a sor. A végrímre törekvés miatt kényszerült Vikár ismét ragrímet használni.

Az utóhang legfigyelemreméltóbb része az éneklés befejezésének mozzanatát kifejező hasonlat. A dal maga veszít erejéből, elfárad, akárcsak a ló, a kasza, a folyó vagy a tűz. Ez utóbbi akkor, ha egész éjen át égett. Ebben a fordítók is egyetértettek, a különbség ismét a szórendből és az igeválasztásból adódik. Rácznál nagyon plasztikusan lustán lobog.

A forrásszöveg ló-hasonlatának Hevonenki hengähtävi,/matkan pitkän mentyänsä sürített mondatszerkezete a két cselekvés egymásutániságára utal. A mentyänsä pontos grammatikai felbontása sen jälkeen, kun se on mennyt: az után, miután ment. A ló vagy egyes fordításban csikó (NK) akkor fárad el, miután hosszú utat bejár.

A víz- és a kaszahasonlat feltehetőleg problematikusabb volt a fordítók számára. Csak Nagy Kálmánnál és Szente Imrénél gyengül és csorbul a kasza, amikor nyári szénát kaszál vagy lassul le a folyó, amint kanyargós szakaszhoz ér. 
Rácz István logikusságra törekedett: ha a ló és a tüz hosszabb ideig tartó cselekvés következményeként vesztett erejéből, akkor a vízzel és a kaszával is így kell történnie:

kemény kasza is kicsorbúl, szénát mire mind levágja,

lassúbb lesz a víz folyása, medrét mire mind bejárja. (RI)

Vikár Béla hasonló megoldást választott, a kaszához kapcsolt ige: metél azonban nem a legszerencsésebb, mivel kaszával nem lehet metélni:

Lám kicsorbul a kaszaél,

Nyáron át, ha szénát metél;

Meghalkúl a víznek útja,

Folyótorkolathoz jutva. (VB)

Barna Ferdinánd hasonlóan indított, azonban a víz esetében olyan képet használt, mely éppen a dinamizmusra, a gyorsaságra asszociál:

Elvásik a vas is maga,

Ha sok szénát kaszált vala,

Víztömeg is alázuhan,

Vízesésnél a folyóban. (BF)

Az általa használt kép akár a következetességre törekvésnek is lehet a jele. Ugyanis ezt követően is találkozunk a dal-víz párhuzammal, melyben a víz zuhatagként jelenik meg:

Még maga a zuhatag sem

Adja a vizét ki egészen,

A jó dalnok se fogja mind

Sorba zengni a dalait. (BF)

A forrásszövegben a párhuzamot a két gondolatritmus hasonló szerkesztésmódja is erősíti:

Eipä koski vuolaskana

laske vettänsä loputen,

eikä laulaja hyväinen

laula tyynni taitoansa. 
A már idézett Barna Ferdinándon kívül a fordítók is erre a párhuzamosságra törekedtek:

Nincsen olyan bő zuhatag,

hogy a vize mind lefolyna,

nincs olyan jó énekmondó,

ki elmondjon minden verset. (NK)

Nem hányja el minden habját bőven zuhogó zúgó sem, nem mondja el minden versét ékes szájú énekes sem. (RI)

Folyó bármi bőven árad, végsőkig vizét nëm adja; bármilyen dërék a dalnok, készletét ki nëm meríti. (SzI)

Rácznál a tagadószó ismétlése a sorok primitív összecsengéséhez vezetett, de ez inkább aláhúzza a párhuzamosságot. Vikár a párhuzamos szerkesztésmód helyett ismét a végrímes megoldáshoz folyamodott:

Zúgó is, bár dúsabb fajta,

Vizét fogytig le nem hajtja,

Dallos, noha nem az alja,

Mind, a mit tud, el nem dallja. (VB)

Míg az előhang többnyire az énekre, a dalra összpontosít, az utóhang az énekesre - annak családjára, származására.

Mit is tudunk meg erről a dalosról?

A dalos szegény, árva, szülei korán elhaltak, mostoha nevelte, már fiatal korában is sokat szenvedett. A dalt, az éneket azonban még gyermekkorában tanulta: otthon, a családi házban, az anyjától, az apjától és a rokonoktól. A családban öröklődő énektudás, a közös emlékek felidézése, azok átöröklése az összetartozás jele. Ez lesz hangsúlyossá a szülő anya és mostoha, valamint az ösztönösen otthon tanult ének és az iskolában szerezhető tudás ellentétbe állításával is. Bár ez utóbbiban a névtelen énekes a tanult olvasóhoz is szól, mintegy bocsánatot és megértést kérve az ének egyszerüsége miatt. Nem véletlenül. Hiszen a dalos származásának azt kellett bizonyítania, hogy az elmondott történet nem iskolában tanult, hanem egyszerre ösztönös és az elődöktől „örökölt”, generációról generációra szálló közös tulajdon - a kollektív tudat része.

Az egyszerü dalos és az elit értelmiség közötti ellentét Vikárnál, Rácznál és Szenténél a dalos és a tudós(abb) ellentéte, míg Barnánál és Nagynál a dalos és a nagyurak ellentétévé vált. Nagy Kálmán szóválasztásának 
értelmezésekor nem vonatkoztathatok el a fordítás születésének idejétől, valamint attól a ténytől, hogy ez az a fordítás, melyben a nép főnév a legtöbbször megjelenik. Az 1960-as évek kommunista Romániájában az értelmiséget vagy a tudóst nem lehetett az egyszerü dalossal vagy a néppel ellentétbe állítani. Nem lehettek egymás ellenségei. A nép egyedüli ellensége a nagyúr lehetett.

Az utóhang utolsó tíz sorának magyar szövegváltozatai nem mások, mint a fordítók összegző olvasatai - a Kalevala műfaját, ezen túlmenően pedig a nemzeti/népi eposznak a társadalmi, kulturális részrendszerben betöltendő feladatát illetően.

Barna Ferdinánd a névtelen énekes feladatát határozta meg, mely nem más, mint a jövő dalosának utat törni, vagyis a hagyomány továbbvitele. Vikár Béla és Rácz István is ezt tartotta a dalos feladatának. Ehhez kapcsolták hozzá az átörökítés fontosságát az újabb nemzedékre. Nagy Kálmán fordításában az új, esetleg jobb énekes útja nem csupán egy dalos, és rajta keresztül egy nemzedék, hanem egy népnek és nemzetnek válik új útjává. Szente Imre pedig magát a dalt helyezte a középpontba, az új út a dalon és az anyanyelven keresztül válik a jobb dalos és az új nemzedék útjává.

\section{4. Összegzés}

A célszövegek egymással és a forrásszöveggel való összevetését az általánosabb formai sajátosságok, valamint a személy- és földrajzi nevek vizsgálata mellett az elő- és utóhangon végeztem el. Ez utóbbin keresztül azt vizsgáltam, hogy milyen fordítói olvasat rajzolódik ki a magyar szövegekből a Kalevala mint eredettörténetet illetően, és hogy ezzel összhangban milyen mértékben foglal el központi helyet a nemzedékről nemzedékre hagyományozódás, valamint a népies vonások hangsúlyozása.

A vizsgálat után összegezzük, hogy a szövegek hogyan viszonyulnak az előző fejezetek végén megfogalmazott elvárásokoz: megfeleltek-e azoknak vagy más eredményre vezettek.

Az első fordító, Barna Ferdinánd szövegével szemben támasztott elvárások nem igazolódtak be. A célkitüzéseiben megfogalmazott stratégiákat, hogy finnugor fogalmi hálót teremtsen, csak a kiadás végén található jegyzetekben érvényesítette, magában a célszövegben ritkán. Fordításában vannak jó megoldások, azonban legtöbbször nem következetes ezek végig vitelében. Különösen a paralelizmusokban érhető tetten ez a fajta következetlenség, főleg, hogy többször is él a kihagyás módszerével. Félrefordítás alig található a szövegben, a magyartalan szerkezetek vádja pedig éppúgy 
vonatkoztatható - a Barnát ezek miatt is bíráló - fordító-utódra, Vikár Bélára is.

Annak az elvárásnak, hogy a forráskultúrára utaló elemeket csak akkor tartja meg, ha valamilyen módon a magyar kultúrához kapcsolhatóak, nem felelt meg a fordító. Maga a szöveg inkább a megmutatást vállalta fel, semmint a magyarrá tevést.

Vikár szövege mindenben megfelelt elvárásainknak. Célkitűzéseiben Barnához hasonló elveket fogalmazott meg, de mühelytanulmányaiból egy Barnánál sokkal tudatosabb fordító képe rajzolódik ki. A célnyelvi olvasót szem előtt tartó stratégiája végrímes és a felező nyolcas sorokban tördelt fordítást eredményez. Azonban különösen a végrímre törekvése sokszor magyartalan megoldásokat vagy kínrímeket eredményezett. Szövege népiességét és archaikusabb voltát a magyar népköltészetből és a dialektusokból egyaránt merítő szókinccsel érte el. A magyar befogadóhoz még úgy hozta közelebb a szöveget, hogy a legtöbb idegenséget hordozó forrásnyelvi neveket lefordította vagy hangalakilag a magyar nyelvhez igazította. Azt is láttuk azonban, hogy ez a módszer sokszor éppen a magyar olvasó szempontjából rossz megoldásokhoz vezetett.

Az eposz múfaji követelményeihez - például, hogy valamiféle ősiségre kell utalnia - az első két fordítás a (cél)nyelvi regiszter megválasztásával idomult. Sőt, sokszor rá is licitáltak a forrásnyelvi szövegre a sok archaizmus használatával. Tisztában vagyok azzal, hogy az első két fordítás majd száz évvel ezelőtt készült, de a korabeli nyelvhasználathoz képest is tartalmaznak archaizmusokat.

A Nagy-szöveggel szemben támasztott elvárások részben beigazolódtak. Nagy Kálmán köznyelven megszólaló Kalevalája az 50-es és 60-as években már-már dogmatikussá vált „formai hüségét” igyekezett megvalósítani. Több mint fél évszázad után az újrafordítást felvető legfőbb okok egyike éppen a Vikár-fordítás nyelvének az elavulása volt. A köznyelvü és archaizmusoktól mentes magyar szöveg a Vikár Béláétól teljességgel eltérő koncepcióról árulkodik. Nagy a kor fordításról vallott felfogásához hủen megtartotta a forrásnyelvi neveket. Ez az olvasóban akár a folyamatos idegenségérzet fenntartásához vezethet, azonban a konkretizálással a magyar olvasónak próbált - az idegenségérzet ellenére is - megmutatni egy másik kultúrát, esetünkben a finnt. Magyar szövege ebből a szempontból forráskultúra-központú. A megmutatás leghangsúlyosabban az utolsó sorokban jelenítődik meg. Az utóhang záró sorai a Kalevalának a finn nép, nemzet életében betöltött meghatározó szerepéről szólnak.

A fordítás megjelenési helye és a fordító személye egyaránt illethető az erdélyi jelzővel, és bár a fogadtatásban erre utaltak, a Nagy Kálmán-i szöveg nyelvhasználata ezt nem támasztotta alá. 
Rácz István szövege csak részben felelt meg az elvárásoknak. Rácz fordításában az alliterációkat tartotta igazán fontosnak. A tudatosan felvállalt fordítói koncepció - az alliterációgazdagság hangsúlyozása - sikeresen megvalósult. Azonban szövegében - Vikár végrímes megoldásához hasonlóan - az alliteráció sokszor szövegszervezőként működik, ami a célszöveg természetességének rovására megy. Nem csupán azért, mert alliterációk számában az eredetit is felülmúlja, hanem mert a fordításban sokkal több melléknevet kénytelen használni, mint ez eredeti.

A megmutatásra vonatkozó elvárásnak nem felelt meg a szöveg. Ez a fordítói intenció kimerült a „,kalevalai” illusztrációk kötetbe illesztésében.

A három utolsó Kalevala-fordító a köznyelvüséget tartotta szem előtt. Rácz és Szente nem archaizmusokkal, hanem a használt - archaikusnak ható, de köznyelvi - mellék- és főnevekkel vagy a köznyelvtől eltérő ragváltozatokkal - -rul, -rül - idomultak a müfaji elvárásokhoz, a népi eposz támasztotta követelményekhez.

A Szente Imre szövegével szemben támasztott elvárások részben igazolódtak. A kifejezetten magyar kultúrkörhöz kötődő fogalmak beiktatásával valóban célkultúra-központú szöveget teremtett. A honosító módszerrel Szente részben visszatért a Vikár Béla-i hagyományhoz. Azonban meglepő módon formailag nem honosított. Nagy Kálmán szövege után ez az a szöveg, mely formailag legközelebb áll a finn szöveghez. A forrásnyelvi alakokat megtartó tulajdonneveken keresztül a megmutatás is érvényesül benne. Szente az eposz szellemiségét igazította a magyar kultúrához. A beiktatott vendégszövegek révén mindenképpen más lett ez a Kalevala, mint a korábbiak. Formabontó újítása: a prózaszerü szöveg - mely megtartja az eredeti ritmust - pedig a szöveg olvashatóságának igen jó szolgálatot tesz.

Az utolsó két fordítás tehát - hűen az elő- és utószavakban, műhelytanulmányokban vállalt fordítói stratégiákhoz - Vikár nyomdokain haladnak és célkultúra-központúak. 



\section{KÖVETKEZTETÉSEK}

A Kalevala teljes magyar fordításainak szövegszintű és fogadtatásbeli vizsgálata után lássuk, hogy az előszóban megfogalmazott hipotézisek mennyiben állják meg a helyüket, illetve mennyiben módosulnak.

A teljes fordítások vizsgálatában az Itamar Even-Zohar többrendszerűség-elméletéből kinövő leíró fordítástudományt használtam elméleti keretként. José Lambert táblázatából kiindulva vizsgáltam meg azokat a viszonyokat, amelyek a fordítások fogadtatására hatással lehetnek: a forrásszöveg és a célszövegek létrejöttének kontextusát - a szerkesztő/alkotó Lönnrot és a magyar fordítók stratégiáit a szövegek létrehozásában.

A fordítókhoz kötött, a magyar Kalevalák fogadtatását vizsgáló fejezetek végén olyan előfeltevésekből indultam ki, melyekre az utolsó fejezetben a szövegszintü elemzést alapoztam.

Barna Ferdinánd és Vikár Béla Kalevala-forditásai a célkultúrában a hiányzó magyar eposz okozta ür betöltését tartották szem elött, a nyelvrokonságból kiindulva, a finnugor hálón belül. Mindketten arra próbáltak rámutatni, hogyan is lehetne a finnugor rokonság jegyében a finn eposzból kölcsönvett eszközökkel létrehozni a magyar nemzeti nagyelbeszélést. Hogy ez nem sikerült, annak több oka is volt. Az egyik ok, hogy a 19. század végén a magyar többrendszer központja már nem az eposz müfajában látta a nemzeti nagyelbeszélés megvalósíthatóságát, ezzel párhuzamosan pedig az irodalomszervezés központi figurái számára a Barna Ferdinánd által csak a jegyzetekben felkínált finnugor háló és fogalmi keret valamiféle rezervátumszerű helyet mutatott az európai makrorendszerben. A felkínált modell egyfelől a finn eposz 19. századi gyors világirodalmi központba kerülésére alapozott - sikertelenül -, a finnugor háló megteremtésére tett kísérleten keresztül pedig a két nyelv rokonságára. Barna célkitüzése azonban a túlságosan is egyedítő és a finnugor hálón belül a magyar mitológiát rekonstruáló törekvésen bukott el. 
Vikár Béla, fordításán keresztül, amint az a fordító műhelytanulmányaiból és a fogadtatásból is kiolvasható, leginkább a műfaji modellt látta a Kalevalában. Ezen túlmenően pedig olyan alapot, melyen a finnugor háló megteremthető lehet. Átültetésének 1930-as évekbeli és azt követő sikere, valamint központba kerülése több tényező együttállásának volt köszönhető. A fordító Vikár kitűnő irodalompolitikai érzékkel választotta ki Kosztolányi Dezsőt az 1935-ös kiadás bevezető esszéjének megírására akkor, amikor a nyelv/néprokonság gondolata rendkívül népszerú volt és a finnugor mozgalmak, a magyar-finn személyes és félhivatalos kapcsolatok hivatalos, Magyarország és Finnország nyelvrokonságon alapuló államközi kapcsolataiba fordultak át. Így meghatározó szerepet játszottak a vikári Kalevala fogadtatásában.

Az 1935-ös magyar Kalevala-kiadás annak ellenére, hogy Vikár fordítói stratégiáját és megvalósításait tekintve nagyon is hasonlított a fordító-előd Barna Ferdinándéhoz, olyan széles befogadói rétegre támaszkodhatott, mely sem 1871-ben, sem pedig 1909-ben, a Vikár-szöveg első megjelenésekor nem volt adott. A finn tulajdon- és földrajzi nevek írásában érvényesített magyar írásmód, a formai megoldások és az alkalmazott fordítói módszerek az idegenségérzet megszüntetését, a honosítást szolgálták. Vikár kitűnő irodalompolitikája, személyes kapcsolatai és rendkívül öntudatos fordítói magatartása valóságos kultuszt teremtett önmaga és szövege köré. Vikár fordításának kanonizál(ód)ása tehát több tényezö szerencsés együttállásának, valamint Vikár önkultusz-konstruáló stratégiájának is eredménye.

Azt is láttuk, hogy a finn eposz a magyar többrendszerben egy olyan részrendszer központi műve maradt, mely az eposzt kulturális és - különösen a két világháború között - politikai modellként állította a középpontba, és nem a műfajisága okán. A II. világháborút követő évtizedben éppen a politikai modell vállalhatatlansága miatt perifériára került a finn eposz finnugor hálón alapuló értelmezése, és helyét a forrásszöveg létrejöttének kontextusára - a gyüjtések helye Szovjet-Karjala volt - összpontosító közeledés váltotta fel. Ezen keresztül sikerült Vikár Béla fordítását központban tartani.

Az 1950-1960-as években, amikor a fordításról való gondolkodásban is változás ment végbe, újfajta elvárásokkal közeledtek a célszövegekhez. A célkultúrába illesztés helyett az idegenségérzet megtartása volt a cél.

Az első újrafordítás - Nagy Kálmán munkája - többek között a vikári fordítás archaikus nyelvezetével szemben, mintegy arra válaszként született. Fogadtatásában a fordító személye ellentmondásos viszonyulást eredményezett. Romániai magyarként ismeretlen volt a magyarországi kritikusok számára, ugyanakkor a mü megjelenése előtt bekövetkezett halála okán leginkább a fordító személye vált fontossá, a fordításról alig nyilatkoztak ér- 
demben. Nagy Kálmán szövege forráskultúra és -szövegközpontúnak tekinthető. Legalábbis nem célközpontú olyan értelemben, mint elődei szövegei. Ô ugyanis nem a múfajt akarta modellként átemelni vagy valamiféle finnugor hálót teremteni. Fordítói olvasatában a Kalevala a finn nép eredettörténete, Lönnrotnak és a finn kollektív tudatnak egyszerre a terméke. Fordításának célja a másság érzékeltetése, a megmutatás volt. Ezt a másságot pedig az idegenségérzet megtartásával - például a finnesen írt tulajdonneveken keresztül - hangsúlyozta.

Ami a negyedik Kalevala-fordító, Rácz István szövegének nyelvezetét illeti, inkább Nagy Kálmánhoz áll közelebb: a 70-es évek magyar köznyelvén szólal meg Kalevalája. Azonban fordítói módszerével a vikári hagyományt folytatta, ugyancsak honosított, vagyis szövege - a hipotézisekben megfogalmazottakkal ellentétben - célkultúra-központú.

Az utolsó teljes magyar fordítás, Szente Imre munkája, a 2000-es években kétszer is megjelent Magyarországon gyors egymásutánban. Szente szövege is célkultúra-központú, hiszen honosításban felülmúlja Vikár és Rácz fordításait is a magyar kultúrkörhöz kötődő fogalmakon keresztül. Ugyanakkor Nagy Kálmán fordítása után ez az a szöveg, mely formailag legközelebb áll a finn szöveghez, ebben pedig forráskultúra-központúnak is tekinthető. A megmutatás is érvényesül benne a forrásnyelvi alakokat megtartó tulajdonneveken keresztül. Formai megoldásai éppen a tartalmi honosításaival mennek szembe.

Tény, hogy az archaizáló Vikár-szöveget az újabb Kalevala-fordítások fokozatosan kiszorították. Az utolsó hipotézisem az volt, hogy a vikári kanonizált Kalevala helyét csakis egy teljesen más koncepciójú szöveg vehette át. Azt gondolom, hogy ezt a helyet Rácz István fordítása foglalta el. Gondoljunk csak a Diákkönyvtár-sorozatban megjelentetett szemelvényes Kalevalákra, melyek Rácz fordításai. Hogy éppen ez az átültetés került a központba, abban nem a Vikárétól eltérő, hanem éppen a hozzá hasonló fordítói stratégia vállalása játszott szerepet. Emellett pedig Rácz István költőiségről vallott egyedi látásmódja, mely az alliteráló Kalevalában öltött testet.

Az eposz teljes szövege magyarul, legyen az bármelyik fordítónak is az alkotása, évek óta nem jelent meg. Talán újra a forráskultúrához kellene fordulni, ahol a Lönnrot-féle eposz más műfajú, intralingvális fordításokként is meghatározható művekben él tovább. Vagy más kulturális rendszerhez, például a színházhoz, mely - amint azt az elmúlt években Szálinger Balázs szövegkönyvén alapuló előadás sikere is bizonyította - újra és újra felfedezi magának a Kalevalát. 



\section{FELHASZNÁLT IRODALOM}

Kalevala (1849). Gummerus, Jyväskylä, 1995.

Kalevala (Ford. Barna Ferdinánd). MTA kiadása, Budapest, 1871.

Kalevala (Ford. Vikár Béla). MTA kiadása, Budapest, 1909.

Kalevala (Ford. Vikár Béla). Budapest, 1935.

Kalevala (Ford. Vikár Béla). Európa, Budapest, 1985.

Kalevala (Ford. Nagy Kálmán). Kriterion, Bukarest, 1972.

Kalevala (Ford. Rácz István). A fordító magánkiadása, Helsinki, 1976.

Kalevala (Ford. Rácz István). Budapest, 1980.

Kalevala (Ford. Szente Imre). Nemzedékek és Nemzetőr, München, 1987.

Kalevala (Ford. Szente Imre). BDTF, Szombathely, 2001.

Kalevala (Ford. Szente Imre). Bárczi Géza Kiejtési Alapítvány, Budapest, 2002.

\section{LÖNNROT, Elias}

1985

A Régi Kalevala előszava. Hazafias Népfront és Akadémiai Kiadó, Budapest. (Ford. Kovács Magdolna)

ALAPURO, Risto

1987 Kansanliikkeet loivat kansakunnan. In: Uő (szerk.): Kansa liikkeessä. Kirjayhtymä, Helsinki, 7-52.

1999 Social Classes and Nationalism: the North-East Baltic. In: BRANCH, Michael (ed.): National History and Identity. Approaches to the Writing of National History in the North-East Baltic Region Nineteenth and Twentieth Century. SKS, Helsinki.

ANTTONEN, Pertti

2002 Kalevala-eepos ja kansanrunouden kansallistaminen. In: LAAKSONEN, Pekka - PIELA, Ulla: Lönnrotin hengessä. SKS, Helsinki, 39-57.

ARANY János

1962a Naiv eposzunk. In: Uő: Összes müvei X. S. a. r. Keresztury Dezső, Akadémiai, Budapest, 264-274. 
1962b Széptani jegyzetek. In: Uő: Összes müvei X. S. a. r. Keresztury Dezső, Akadémiai, Budapest, 532-565.

1962c Irányok. In: Uő: Összes müvei XI. S. a. r. Keresztury Dezső, Akadémiai, Budapest, 164-170.

BABITS Mihály

1912 Dante fordítása. Műhelytanulmány. Nyugat (8.) 659-680.

1920 Előszó. In: Uő: Pávatollak. A Táltos kiadása, Budapest, 5-6.

BAJOR Andor

1966 Egy készülő fordításról. Utunk VII. 22.

BALASSA Imre

1935 Utószó. In: Vikár Béla: Magyarázatok a Kalevalához. La Fontaine Társaság, Budapest, 113-115.

BALASSA József

1934 Vikár Béla hetvenöt éves. Magyar Nyelvőr (3-4.) 48-49.

1936 A magyar Kalevala jubileumi kiadása. Magyar Nyelvốr

BÁN Aladár (7-8.) 128.

1909 Kalevala (ism.). Magyar Középiskola (8.) 504-505.

1910 A Kalevala és új fordítása. Budapesti Szemle (397.) 111-126.

1926 A finn nemzeti irodalom története. Szent-István-Társulat. Az

Apostoli Szentszék könyvkiadója, Budapest.

1935a Kalevala. Élet (15.) 293-295.

1935b Vikár Béla Kalevala-fordításának új kiadása. Budapesti Szemle 374-377.

1935c A százéves Kalevala. Turán (1-4.) 1-8.

BARNA Ferdinánd

1871 Előszó. In: Kalevala. Akadémiai, Budapest, V-XV.

BART István

1981 A mérce. In. Uő - RÁKOS Sándor (szerk.): A müfordítás ma.

Gondolat, Budapest, 237-269.

BARTÓK János

$1990 \quad$ Vikár Béla. Magyar Nemzet augusztus 14.6.

BEKE Ödön

1910 A finnek nemzeti eposza. Magyar Nyelvör 164-174.

BERECZKI Gábor

1988 Suomalainen kirjallisuus unkarilaisen lukijan ja kääntäjän

silmin. In: NIKKILÄ, Hannu (toim.): Vanhan kirjallisuuden vuosikirja, Vammala, 61-74. 
BÉRES Gyula - HEISZ Károly - KLUJBER László

1970 Vikár Béla emlékünnepség Kaposvár - Hetes 1969. április 19-én

és 20-án, Vikár Béla születésének 110. évfordulóján. Kiadja a Somogy

Megyei tanács VB Művelődési Osztálya.

CSEKEY István

1936

CSEPREGI Márta

A Kalevala jubileumi magyar kiadása. Napkelet (1) 12-20.

1993 Jo kävi ilo ilolle. Egy kalevalai motívum vizsgálata a források és fordítások tükrében. In: KARANKO-PAP, Outi - VÁRADY Eszter (szerk.): Tanulmányok a finn nyelvról és kultúráról - Tutkielmia suomen kielestä ja suomen kulttuurista. Budapest, 29-35.

1993b Válogatok vers javábul, gyönyörü dalokat gyújtok. A Kalevala magyar fordításairól. Holmi (10) 1463-1469.

CSERNEY József

1902 A müfordítás kérdésének története a magyar irodalomban. Jurcsó Antal könyvnyomdája, Kalocsa.

DÁNIELISZ Endre

1970

A mi Kalevalánk. Korunk (5) 786-788.

DÁVID Gyula - VERESS Zoltán (szerk.)

2008 Kik vagyunk és miért. Írások az identitásról. EKE, Stockholm.

DÁVIDHÁZI Péter

1989 Isten másodszülöttje. A magyar Shakespeare-kultusz természetrajza. Gondolat, Budapest.

1998 A nemzeti nagyelbeszélés újjászületése. A narratív identitás müfajvándorlása irodalomtól tudományig. Alföld (2) 61-77.

DEBRECZENI Attila

2005a Nemzet és identitás. In: BÉNYEI Péter - GÖNCZY Monika (szerk.): Nemzet - identitás - irodalom. Debrecen, 197-225.

2005b Beszédmód és identitás a 18. század végének magyar irodalmi nyilvánosságában. In: BÉNYEI Péter - GÖNCZY Monika (szerk.): Nemzet - identitás - irodalom. Debrecen, 260-292.

DEDINSZKY Gyula

1991 Maassa maan tavalla. Unkarilaisstipendiaatti kertoo morsiamelleen Suomesta 1927-1928. Lapua, Herättäjä-Yhdistys.

DOMOKOS Péter

1972 A finn irodalom fogadtatása Magyarországon. Modern Filológiai Füzetek. Akadémiai, Budapest.

1973 Az új magyar Kalevaláról. Nagyvilág (7) 1092-1094.

1983 A Kalevala és Magyarország. Magyartanitás (6) 249-258.

1985 A Kalevala sorsa Magyarországon. Szovjet Irodalom (6) 138-142.

1989 Az ötödik magyar Kalevala. Nagyvilág (5) 769-771. 
1991 Barna Ferdinánd. Akadémiai, Budapest. (A múlt magyar tudósai sorozat)

2001 A Kalevala nálunk és nyelvrokonainknál. In: A Kalevala végleges szövege 150 éves. Specimina Fennica, Tomus IX., Savariae, 11-18.

DUGÁNTSY Mária

1973 Nagy Kálmán: Kalevala. Tiszatáj (4) 104-106.

EGEY Emese

2002 A két világháború közötti magyar-finn-észt kapcsolatok történetéból - társasági, diplomáciai, katonai együttmüködés. ELTE, Budapest. (kézirat)

EVEN-ZOHAR, Itamar

$1990 \quad$ Polysystem Studies. Poetics Today 11. (1) Spring.

1995a A többrendszerüség elmélete. Helikon (4) 434-450. (Ford. Ambrus Judit)

1995b Az „irodalmi rendszer”. Helikon (4) 452-467. (Ford. Ambrus Judit)

FALUDI Ágota, CS.

1959 Előszó. In: Kalevala. Európa, Budapest, I-XXVIII. (Ford. Vikár Béla)

FALUS Róbert

1962 Horatius összes versei - Opera omnia Horatii. Filológiai Közlöny (1-2) 206-217.

FEHÉR Pál, E.

$1973 \quad$ Az új magyar Kalevala. Népszabadság VIII. 8. 7.

FEHÉRVÁRI Győző

2001a Szente Imre Kalevalája. Credo (3-4) 179-182.

2001b Az ötödik teljes magyar Kalevala. Magyar Napló júl.-aug.szept. 110-111.

2002a Magyar Kalevalák. Kortárs (6) 77-91.

2002b Dalnak új utat mutattam. A Kalevala és a Kalevipoeg összehasonlitó elemzése, magyarországi fogadtatása és hatása. Kisebbségkutatás könyvek. Lucidus Kiadó, Budapest.

FERENCZI László

1981 Adalékok a felszabadulás utáni magyar müfordítás kérdéséhez. In: BART István - RÁKOS Sándor (szerk.): A müfordítás ma. Gondolat, Budapest, 11-50.

FUCHS, Dávid Rafael

1909 Kalevala (ism.). Keleti Szemle 160-161.

GALLÉN-KALLELA, Akseli

1929 Kalevalan päivänä. KSV (9) 208-210. 


\section{GÁSPÁR Sándor}

1977

Kalevala-fordítások. Korunk (8) 653-658.

GENTZLER, Edwin

1993 Polysystem theory and Translation studies. In: Uő: Contemporary Translation Theories. Routledge, London/New York, 105-143.

GEREVICH KOPTEFF Éva

2003 Madách Az ember tragédiája és finn fordításai a nemzeti kultúrák, az irodalmi recepció és fordításelemzés tükrében. Helsingin yliopisto, (http://ethesis.helsinki.fi/julkaisut/hum/suoma/vk/gerevich-kopteff/madachaz.pdf - PhD-dolgozat)

GERŐ András

2005 Előszó. In: ROMSICS Ignác-SZEGEDY-MASZÁK Mihály (szerk.): Mi a magyar? Habsburg Történeti Intézet, H. n. 7-11.

GOMBÁR Endre

1977 A negyedik magyar Kalevala. Nagyvilág (10) 1566-1568.

GOMBOCZ Zoltán

1909 Kullervó énekei. Egyetemes Philologiai Közlöny 140-141.

GOMBOS László

1942 Dalban született nemzet. Erdélyi Helikon 782-788.

1946 Vikár Béla (1859-1945). Magyar Nyelvőr (1) 5-8.

GÖNCZ Árpád

1981 A fordítás helye és feladata a magyar irodalomban. In:

BART István - RÁKOS Sándor (szerk.): A müfordítás ma. Gondolat, Budapest, 51-60.

GULYÁS Pál

1937 Út a Kalevalához. In: NYIRKOS István (szerk.): Utunk Pohjolába, Békéscsaba, 59-84.

1943 Kalevaláról. In: Kalevala. Magyar Élet, Budapest, 292-341.

(Ford. Vikár Béla)

HAJDÚ Péter

$1985 \quad$ Utószó. In. Kalevala. Helikon, Budapest, 331-335.

1994 Budenz és a Kalevala. Magyar Nyelv 65-71.

HAJDÚ Péter - RUMOHR-NORIO, Liisa - TERVONEN, Viljo

1994 Budenz József a Kalevaláról. Néprajz és Nyelvtudomány (35) 25-45.

HATVANY Lajos

$1908 \quad$ Szimat és ízlés. Nyugat (10) 568.

HEIKKILÄ, Päivi - KARIG, Sára

1984 Barátok, rokonok. Tanulmányok a finn-magyar kulturális kapcsolatok történetéból. Európa, Budapest.

HERRMAN Antal

1905 Vikár Béla Kalevala-fordítása. Ethnographia 244-250. 
HIRVONEN, Maija - MAKKONEN, Anna - NYBONDAS, Anna

198115 vuosikymmentä. Kirjallisia dokumentteja erään seuran historiasta. SKS, Helsinki.

HORVÁTH Imre

1959 Emlékezés Vikár Bélára. Jelenkor (3) 77-82.

HUOTARI, Tauno - KAUKONEN, Väinö

1984 A Finn-Magyar Társaság. In: HEIKKILÄ, Päivi - KARIG

Sára: Barátok, rokonok. Tanulmányok a finn-magyar kulturális kapcsolatok történetéból. Európa, Budapest, 231-239.

IGNOTUS

1910 A fordítás múvészete (recenzió). Nyugat (3) 471-472.

IMRE László

1996 Múfajok létformája a 19. századi epikánkban. Kossuth kiadó, Debrecen.

2002a A műfajok hierarchiája és az irodalomfejlődés problémái a 19. századi finn, orosz és magyar irodalomban. In: Uő: Müfajtörténet és/vagy komparatisztika. Tiszatáj könyvek, Szeged, 83-94.

2002b Egyedi és általános az európai irodalmakban. In: Uő: Müfajtörténet és/vagy komparatisztika. Tiszatáj könyvek, Szeged, 95-99.

2005 A magyarság identitástudata a 19. században. In: BÉNYEI

Péter - GÖNCZY Monika (szerk.): Nemzet - identitás - irodalom. Debrecen, 226-235.

JAUSS Hans-Robert

1999 Recepcióelmélet-esztétikai tapasztalat-irodalmi hermeneutika.

Osiris, Budapest.

JÁVORI Jenő (j. j.)

1985 Jubileumi Kalevala. Könyvvilág (3) 11.

JÁVORSZKY Béla

$1970 \quad$ Kalevala földjén. Nagyvilág (6) 931-932.

1973 A harmadik magyar Kalevala. Magyar Nemzet III. 11. 12.

1977 A negyedik Kalevala. Élet és Irodalom márc. 5. 10.

1988 A Kalevala mint versregény. Hitel (4) 28.

JÓZAN Ildikó

1998 Fordítás és intertextualitás. In: KABDEBÓ Lóránt et al.

(szerk.): A forditás és intertextualitás alakzatai. Anonymus, Budapest, 133-145.

2003 Irodalom és fordítás. Literatura (4) 408-426.

JUTIKKALA, Eino - PIRINEN, Kauko

1996 A History of Finland. WSOY, Juva. 
KANDRA Kabos

1897 Magyar Mythologia. Beznák Gyula könyvkereskedő bizománya. Eger.

KARDOS László

1958 A magyar müfordítás problémái a felszabadulás után. Nagyvilág (8) 1236-1239.

1959 Müfordításunk mai kérdéseiről. In: Uő: Vázlatok, esszék, kritikák. Szépirodalmi, Budapest, 276-296.

1973 A müfordítás kérdései. In: Uő: Iró, írás, irodalom. Magvető, Budapest, 70-124.

KARKAMA, Pertti

1989 J. V. Snellmanin kirjallisuuspolitiikka. SKS, Helsinki.

2001 Kansakunnan asialla. Elias Lönnrot ja ajan aatteet. SKS, Helsinki.

2002 Oppinut mies kansan asialla. Elias Lönnrot ja aatteet. In: LAAKSONEN, Pekka -PIELA, Ulla (toim.): Lönnrotin hengessä. SKS, Helsinki, 15-38.

KAUKONEN, Väinö

1979 Lönnrot ja Kalevala. SKS, Helsinki.

1982 AKalevala a finn-magyar kulturális kapcsolatokban. Suomi (1) 21.

1983 A Kalevala születése. Gondolat, Budapest.

KENYERES Zoltán

1974 Költői műfordításunk negyedszázada. In: Uő: Gondolkodó irodalom. Szépirodalmi, Budapest, 323-389.

KÉPES Géza

1961 A Kalevala és a magyar irodalom. Világirodalmi Figyelő 67-80.

1962 Két ismeretlen József Attila dokumentum. Új Írás (5) 520-522.

KINCSES NAGY Éva

1991 A turáni gondolat. In: Uő (szerk.): Östörténet és nemzettuKISS Antal

dat. Magyar Ôstörténeti Könyvtár, Szeged, 44-49.

1984 Ő maga út volt. Vikár Béla (1859-1945). Napjaink (5) 27-28.

KLAUDY Kinga

1997 A fordítás elmélete és gyakorlata. Scholastica, Budapest.

KLINGE, Matti

1993 Finnország rövid története. In Forma, Nyíregyháza.

KOCZOGH Ákos

1977 Élő Kalevala. Népszava febr. 6. 8.

KOROMPAY Bertalan

1956 Béla Vikárin muisto. KSV (36) 326-329.

1959 Emlékezés Vikár Bélára. Nyelvtudományi Közlemények 388-391. 
1989 A Kalevala keletkezése. In: Uő: Finn nyomokon I., A szerző saját kiadása, Budapest, [1935] 17-45.

KÓS Károly

$1935 \quad$ Kalevala. Erdélyi Helikon (9) 635-637.

KOSKIMIES, Rafael

$1978 \quad$ Kalevalan estetiikka. SKS, Helsinki.

KOSZTOLÁNYI Dezső

$1914 \quad$ Modern költók. Szépirodalmi, Budapest.

1935 Kalevala. In: VIKÁR Béla: Magyarázatok a Kalevalához. La Fontaine Társaság, Budapest, 3-13.

KOVÁCS Máté

$1944 \quad$ Kalevala (ism.). Magyar Lélek (1) 48.

KOVÁCS N. Tímea (szerk.)

$2004 \quad$ A fordítás mint kulturális praxis. Jelenkor, Pécs.

KOVÁCS Zoltán

1958 A karjalai-finn eposz történeti alapjai. Világirodalmi Figyelő

(2) 169-173.

KROHN, Julius

1897 Suomalaisen kirjallisuuden vaiheet. SKS, Helsinki.

KUPIAINEN, Unto

1958 Suomen kirjallisuuden vaiheet. WSOY, Juva.

KUUSINEN, Otto

1950 Előszó. In: Kalevala, szemelvények a karjalai-finn nép eposzá-

ból. Hungária, Budapest, 3-15.

LAAKSONEN, Pekka - PIELA, Ulla (szerk.)

2002 Lönnrotin hengessä 2002. SKS, Helsinki.

LACZKÓ András

1990 Vikár Béla sem jó? Magyar Nemzet 1990. július 9. (Visszhang-melléklet) 4.

LAIHIALA-KANKAINEN, Sirkka - PIETIKÄINEN, Sari - DUFVA, Hannele (szerk.)

2002 Moniä̈ninen Suomi. Kieli, kulttuuri ja identiteetti. Jyväskylän yliopisto, Soveltavan kielentutkimuksen keskus.

LAITINEN, Kai

1981a Suomen kirjallisuuden historia. Otava, Keuruu.

1981b A finn irodalom története. Gondolat, Budapest.

LAKATOS István

1973

Az új magyar Kalevala. Élet és Irodalom február 23. 10. 
LAMBERT, José

2006

Functional Approaches to Culture and Translation. Selected papers by José Lambert. (csak az angol nyelvü tanulmányok) John Benjamins Publishing Company, Amsterdam/Philadelphia.

LEFEVERE, André

1992 Translation, Rewriting and Manipulation of Literary Fame. Routledge, London, New York.

$1994 \quad$ Translating Literature: practice and theory in a comparative literature context. Modern Language Association of America, New York (1992: reed. 1994).

1998 The Gates of Analogy: The Kalevala in English. In: BASS-

NETT, Susan - LEFEVERE, André (ed.): Constructing Cultures. Essays on Literary Translation, Multilingual Matters. Clevedon, Philadelphia, 76-89.

LISZTÓCZKY László

1984 Gulyás Pál és Vikár Béla barátsága. Irodalomtörténet 222. 458-468.

1988 Az ötödik teljes. Szente Imre Kalevala-fordítása. Alföld (9) 95-96.

1998 A csodaszarvas a Kalevala erdejében. Pallas, Gyöngyös.

MARGÓCSY István

1998 "A tiszta magyar". nemzetkarakterológia és nemzeti törté-

nelem összefüggései Bessenyei és kortársai nyelvrokonság-felfogásában. In: CSORBA Sándor - MARGÓCSY Klára (szerk.): A szétszórt rendszer. Bessenyei György Könyvkiadó, Nyíregyháza, 131-140.

2005 A nyelv mint a nemzet közkincse. In: GYÖRGY Péter KISS Barbara - MONOK István (szerk.): Kulturális örökség - társadalmi képzelet. OSZK, Akadémiai, Budapest, 31-40.

MOLNÁR Lajos

1959 Emlékezés Vikár Bélára. Reformátusok Lapja (22) 3.

1962 Emlékezés Vikár Bélára. Reformátusok Lapja (31) 3.

1970 Megemlékezés Vikár Béláról halála 25. évfordulóján. Theologiai Szemle (11-12) 372-374.

MIKLÓS Róbert

$1944 \quad$ Kalevala. Sorsunk (2) 122-124.

MÓZES Huba

1973 Néhány szó a Kalevaláról és magyar fordításáról. Korunk (4) 639-641.

MUSIKKA, Väinö

1938-1939 Suomalaiset, eestiläiset ja magyarit, suuri suomalais-ugrilainen heimoyhteys. Heimotyö 69-73. 
NAGY Emilné dr. Göllner Mária

1940 A Kalevala titkáról. A nagy finn hősköltemény népszerü ismertetése. Magyar-finn Társaság. Budapest.

NAGY Kálmán

1967 Néhány szó a Kalevaláról. Igaz Szó (4) 570-578.

1969 A Kalevala. Múvelődés (10) 48-52.

1971 A százéves magyar Kalevala. Utunk VIII. (27) 2.

NAGY Pál

1973 Ilyennek látom. Igaz Szó (9) 364-366.

NUMMINEN, Jaakko

1984 Bevezetés. A finn-magyar kulturális kapcsolatok fejlődé-

se. In: HEIKKILÄ, Päivi - KARIG Sára: Barátok, rokonok. Tanulmányok

a finn-magyar kulturális kapcsolatok történetéböl. Európa, Budapest, 9-15.

NYIRKOS István

1973 A kölcsönös érdeklődés jegyében. Alföld (6) 72-78.

1974 Lönnrot és a Kalevala. Alföld (9) 59-68.

1985 Utunk Pohjolába. Nyirkos (összeáll.), Békéscsaba.

2001 AKalevala hatása a finn és a magyar kultúrában. In: A Kalevala végleges szövege 150 éves. Specimina Fennica, Tomus IX., Savariae, 39-54.

ODORICS Ferenc

1989 Új paradigma-e az empirikus irodalomtudomány? Helikon (Világirodalmi Figyelő) (1) 4-22.

OIKARI, Raija

2001 Vallankäytöstä Suomen ja Unkarin kirjallisissa kulttuurisuhteissa. Jyväskylän yliopisto, PhD-dolgozat, kézirat.

PÁLFFI Márton

1935 A százéves Kalevala. Pásztortüz 503-505.

PÉLI Árpád

1985 Kalevala-fordítások. Hajdú-Bihari Napló febr. 28. 5.

PENTIKÄINEN, Juha

1989 Kalevala Mythology. Indiana University Press, Bloomington and Indianapolis.

2001 A Kalevala mint mítosz és történelem. In: A Kalevala végleges szövege 150 éves. Specimina Fennica, Tomus IX., Savariae, 33-38. PESONEN, Matti

1925 A finn-ugor népek kulturális egysége. Fenno-Ugria (1) 15-21. POLGÁR Anikó

2003 Catullus noster. Catullus-olvasatok a 20. századi magyar költészetben. Kalligram, Pozsony. 
PUSZTAI János

1973

Szökésben volt. Igaz Szó (9) 366-367.

PUSZTAY János

$1973 \quad$ Új magyar nyelvü Kalevala. Népszava augusztus 4. 5.

1975 A Kalevala napja. Népszava március 1. 6.

1982 Magyar nyelvü Kalevalák. Kritika (2) 28-29.

2001 A Kalevala - egy eposz és a nyelv. In: A Kalevala végleges szövege 150 éves. Specimina Fennica, Tomus IX., Savariae, 55-62.

RADÓ Antal

1909 A fordítás müvészete. Franklin-Társulat, Budapest.

RADÓ György

1967 A finn eposz és az észt eposz eltérő társadalomábrázolásának történelmi okairól. Helikon (1) 41-53.

RÁCZ István

1976 Eligazító. In: Kalevala. A fordító magánkiadása, Helsinki, 400-405. (Ford. Rácz István)

1980 Eligazító. In: Kalevala. Európa, Budapest, 397-409. (Ford.

Rácz István)

ROMMI, Pirkko - POHLS, Maritta

1989 Poliittisen fennomanian synty ja nousu. In: TOMMILA,

Päiviö (szerk.): Herää Suomi. Gummerus, Jyväskylä, 67-117.

RUFFY Péter

1975 Kalevala. Az erdélyi Nagy Kálmán új fordítása. Magyar Nemzet IX. 7. 13.

SALMINEN, Väinö

1906 D. E. D. Europaeus. SKS, Helsinki.

SCHELKEN Pálma

1958 Emlékezés a Kalevala és Rusztaveli első magyar fordítójá-

ra Vikár Bélára. Magyar Nemzet ápr. 1. 7.

1958 Emlékezés Vikár Bélára. Muzsika (6) 12-15.

1965 Húsz éve hunyt el Vikár Béla. Köznevelés (22) 875.

SCHMIDT J., Siegfried

1989 Az empirikus irodalomtudomány EIT: új paradigma. $\mathrm{He}$ -

likon (Világirodalmi Figyelő) (1) 23-40.

SEBESTYÉN Gyula (S-a)

1901 Vikár Béla: A Kalevalából. Ethnographia 381-383.

SEBESTYÉN Károly

1909 A magyar Kalevala. Budapesti Hírlap május 6. 11-12.

SIPOS Csaba

1984 Vikár Béla. Somogyi Honismereti Híradó (1) 120-122. 
SIHVO, Hannes

$2003 \quad$ Karjalan kuva: karelianismin taustaa ja vaiheita autonomian aikana. SKS, Helsinki.

SOMLYÓ György

1981 Két szó között. In: BART István - RÁKOS Sándor (szerk.):

A múfordítás ma. Gondolat, Budapest, 102-146.

STOLL Béla

$1950 \quad$ Kalevala. Irodalomtörténet (3) 127-128.

SULKUNEN, Irma

2004 Suomalaisen Kirjallisuuden Seura 1831-1892. SKS, Hämeenlinna.

SZABÓ Lőrinc

2002 Bevezetés az Örök barátaink I. kötetéhez. [1942]; Bevezetés a Válogatott műfordítások kötethez. [1950] In: Uő: Örök barátaink. Osiris, Budapest.

SZABÓ T. Ádám

1974 Uusi unkarinkielinen Kalevala. KSV (54.) 387-391.

SZAJBÉLY Mihály

2005 A nemzeti narratíva szerepe a magyar irodalmi kánon alakulásában Világos után. Universitas, Budapest.

SZÁSZ Károly

1929 A világirodalom nagy eposzai. Révai, Budapest.

SCHEDEL (TOLDY) Ferenc

1843 A müfordítás elveiról. Kisfaludy-Társaság, Buda.

SZEGEDY-MASZÁK Mihály

1998 Fordítás és kánon. In: KABDEBÓ Lóránt et al. (szerk.): A forditás és intertextualitás alakzatai. Anonymus, Budapest, 66-92.

SZEKFÜ Gyula

1939 Előszó. In: Mi a magyar? Magyar Szemle Társaság, Budapest, (repr. 1992), 7-12.

SZENDE Aladár

1944 A Kalevala új kiadása. Magyar Út (4) 6.

SZENDREI László

2007 A turanizmus: ön- és negatív definíciók, értelmezések 1910-töl a

II. világháborúig. Könyv és Könyvtár, 78-125.

SZENTE Imre

1987 A fordító előszava. In: Kalevala. A Nemzedékek és Nemzetôr közös kiadása, München, 5-9.

2003 Kalevala-fordításom műhelytitkai. In: Uő: Szabad szemmel.

Esszék, jegyzetek, előadások. Stockholm, 108-132.

SZÉLL Jenő

1980 Új magyar Kalevala. Könyvvilág (7) 4. 


\section{SZÍJ Enikő}

1985

A Kalevala és a magyarok. Különlenyomat a Nyelvtudományi Közlemények 87. kötetének 2. számából, 399-417.

1991 Finnugor néprokonsági eszme a 20-as, 30-as években. In: KINCSES NAGY Éva (szerk.): Ôstörténet és nemzettudat, Magyar Ôstörténeti Könyvtár, Szeged, 72-88.

1998 Pánfinnugor és antifinnugor elméletek, mozgalmak. In:

DOMOKOS Péter - CSEPREGI Márta (szerk.): 125 éves a budapesti Finnugor Tanszék. Urálisztikai Tanulmányok 9., ELTE, 145-152.

2008 Volt-e, van-e, lesz-e finnuogr szolidaritás? Válaszok egy képzelt interjú kérdéseire. In: DÁVID Gyula - VERESS Zoltán: Kik vagyunk és miért. Írások az identitásról. EKE, Stockholm, 299-322.

SZILÁGYI Domokos

1967 Új Kalevala elé. Korunk (3) 389-390.

1973 Uusi Kalevala. Utunk (5) 1-2.

SZILÁGYI Júlia

$1989 \quad$ Nagy Kálmán titka. Utunk (23) 4.

SZILY Ernő

$1975 \quad$ Nyelvrokonok vonzásában. Könyvvilág (9) 2.

\section{SZLÁVIK Mátyás}

1909 Vikár Béla: Kalevala. Protestáns Szemle 401-405.

SZOPORI NAGY Lajos

1978 A legújabb magyar Kalevala. Nyelvtudományi Közlemények

(2) 445-446.

2002 A finnek megítélésének hullámzása Magyarországon. In: Hatalom és kultúra. Plenáris előadások. V. Nemzetközi Hungarológiai Kongresszus, Jyväskylä, 191-199.

SZOPORI NAGY Lajos - VARPIO, Yrjö

1990 Ismerkedő ismerösök. A magyar irodalom fogadtatása Finnországban és a finn irodalom fogadtatása Magyarországon. OSzK Könyvtártudományi és Módszertani Központ, Budapest.

TAKALO, Tenho

1986 Unkari Suomessa 1920- ja 1930-luvuilla. Heimotyötä, kulttuurisuhteita vai „revisiopolitiikka”? In: Yksilö ja yhteiskunnan muutos. Acta Universitatis Tamperensis, Ser. A, vol. 202., Tampereen Yliopisto, Tampere, 182-203.

TAKÁTS Gyula

1966 Vikár Béla és a Kalevala. Kortárs (3) 484-485.

1971 Vikár Béla emléktáblájánál. In: Uő: Egy kertre emlékezve. Müvek és mesterek között. Szépirodalmi, Budapest, 145-151. 
1971 A Kalevala és Vikár. In.: Uő: Egy kertre emlékezve. Müvek és mesterek között. Szépirodalmi, Budapest, 152-157.

TERVONEN, Viljo

2001 Nagy Kálmán, a Kalevala harmadik magyar nyelvű fordítója. Helikon (21) (nov.10.) 16-17.

TOMMILA, Päiviö

1989 Mitä oli olla suomalainen 1800-luvun alkupuolella. In: Uő

(toim.): Herää Suomi. Gummerus, Jyväskylä, 49-65.

TOURY, Gideon

1995 Descriptive Translation Studies and Beyond. John Benjamins

Publishing Company, Amsterdam/Philadelphia.

TÜSKÉS Tibor

1977 Kalevala. Rácz István fordítása. Jelenkor (12) 1150-1151.

VAJDA Aurél

1985

VAJDA László

1968 A Kalevala világa. Kortárs (9) 1472-1480.

VARGA Domokos

1973 Köznyelvü Kalevala. Kortárs (9) 1513-1516. Ua. Igaz Szó (9) 359-364.

1990 Öt magyar Kalevala. Szovjet irodalom (6) 123-131.

VARGA P. Ildikó

$2004 \quad$ Nagy Kálmán Kalevala-fordításának kritikai fogadtatása. In: T. SZABO Levente - VIRGINÁS Andrea (szerk.): RODOSZ-tanulmányok 2003. Kriterion, Kolozsvár, 190-199.

2006 Problémák a Kalevala magyar fordításainak recepciójában. In: PUSZTAY János (szerk.): Specimena Fennica. Colloquia Contrastiva, Tomus XIV., Kaukovertailuja V., Savariae, 298-312.

2007a Az újraírt Kalevala. Szente Imre fordítása. In: CSEPREGI Márta - MASONEN Virpi (szerk.): Grammatika és kontextus - új szempontok az uráli nyelvek kutatásában. Urálisztikai tanulmányok 17. Budapest, 339-347.

2007b Politikum és irodalom összefonódása Vikár Béla Kalevalafordítása kapcsán. In: T. SZABÓ Levente - ZABÁN Márta (szerk.): RODOSZ-tanulmányok. Kriterion, Kolozsvár, 372-380.

2007c Az ötödik magyar Kalevala. In: T. SZABÓ Levente-ZABÁN Márta (szerk.): RODOSZ-tanulmányok. Kriterion, Kolozsvár, 273-283.

2008a Vikár Béla Kalevala-fordítása(i). In: BERECZKI András - CSEPREGI Márta - KLIMA László (szerk.): Ünnepi írások Berecki Gábor tiszteletére. ELTE Finnugor Tanszék - Numi Tórem Finnugor Alapítvány, Budapest, 808-815. 
2008b Fordítói nézőpontok a finn Kalevala magyar átültetéseiben. Erdélyi Múzeum (1-2) 45-61.

2009 A magyar Kalevala. A finn eposz jubileumi magyar kiadása. Erdélyi Múzeum (1-2.) 41-48.

2010a Nyugati háló - finnugor háló: saját - idegen. Barna Ferdinánd Kalevala-fordításáról. In. BÁNYAI Éva (szerk.): Kultúrák határán II. Romániai Hungarológiai Társaság, Bukarest - Sepsiszentgyörgy, 107-116.

2010b "Serdülők serény serege" - Rácz István alliteráló Kalevala-fordításáról. BBTE. (Megjelenés alatt.)

VARGA Pál, S.

2005a Mi a nemzeti irodalom? Mitől nemzeti az irodalom? In: BÉNYEI Péter - GÖNCZY Monika (szerk.): Nemzet - identitás - irodalom. Debrecen, 236-259.

2005b A nemzeti költészet csarnokai. A nemzeti irodalom fogalmi rendszerei a 19. századi magyar irodalomtörténeti gondolkodásban. Balassi, h. n.

VARGHA Balázs (összeálll.)

1957 Homér és Osszián. Magvető, Budapest [!1958] 419-421.; 421-429.

VARPIO, Yrjö

1999 Land of the North Star. An Introduction to Finnish Literature and Culture. Tampere University Press, Tampere.

VARPIO, Yrjö - HUHTALA, Liisi (toim.)

1999 Suomen kirjallisuushistoria I. Hurskaista lauluista iloistelevaan romaniin. SKS, Helsinki.

VARRÓ István

1929 A hetvenéves Vikár Béla. Századunk (4) 229-230.

VÄISÄNEN, A. O.

1944-1945 Béla Vikár (1859-1945) KSV (24-25) 277-280.

VIKÁR Béla

1890 A Kalevala. Budapesti Szemle 161-199.

1909 Elöljáróban. In: Kalevala. Akadémiai, Budapest V.-XVI. (Ford. Vikár Béla)

1929 Kalevala-käännökseni vaiheita. KSV (9) 211-223.

1936 Budenz és a Kalevala. Magyar Nyelvór 67-69.

VILKUNA, Kustaa

1967 Miksi juuri suomalais-unkarilaiset kulttuurisuhteet ovat jatkuvasti vilkkaat? Valvoja (2.) 78-82.

VIRÁNYI Elemér

1940 A Kalevala száz év távlatából. Különnyomat a Turán - Magyar Néprokonsági Szemle XXIII. évf. III. Számából, Budapest. 
VOIGT Vilmos

1997 Irodalom és nép északon. Universitas, Budapest.

2001 A Kalevala tartalma és szerkezete. In: A Kalevala végleges

szövege 150 éves. Specimina Fennica, Tomus IX., Savariae, 19-32.

2007 AKalevaláról és értékeiről. In: Kalevala. Európa, Budapest, 159-194.

VOLLY István

1959 Somogyi „Kalevala”. Vikár Béla Somogyban. Somogy Megyei tanács VB Művelődésügyi Osztálya, Kaposvár.

WEÖRES Gyula

1958 Béla Vikárin Kalevala-käännös. KSV (38) 266-273.

1962 Ferdinánd Barna, Kalevalan unkarintaja. KSV (42) 145-154.

ZEMPLÉNI Árpád

1935 Levél Vikár Bélához. In: VIKÁR Béla: Magyarázatok a Kalevalához. La Fontaine Társaság, Budapest, 119-120.

ZOLNAI Gyula

1930

ZSIRAI Miklós

1939 Nyelvünk alkata. In: SZEKFÚ Gyula (szerk.): Mi a magyar?

Magyar Szemle Társaság, Budapest, 193-216.

ZSOLDOS Jenő

1959 Vikár Béla születésének századik évfordulójára. Magyar Nyelvör (3) 372-373.

\section{Azonosítatlan szerzôjứ írások:}

1871 (Barna Ferdinánd fordításának megjelenéséről). Figyelő (20) 240.

(Barna Ferdinánd fordításának megjelenéséről). Reform júl. 28.

$1905 \quad$ Kullervo bosszúja. Vasárnapi Újság 147.

$1908 \quad$ Kullervo énekei. Egyetértés dec. 20.35.

1934 A Kalevala új magyar kiadása és Vikár Béla jubileuma. $L i-$ teratura máj.1.

1935 dL: (Szuomi). Erdélyi Fiatalok nyári szám

1936 Az ezer tó világának éposza. Literatura 62.

$1940 \quad$ Kalevala. Magyar Kulturszemle (3) 64.

$1944 \quad$ Kalevala. Új Élet (1) 31.

1944 (k): Kalevala. Protestáns Tanügyi Szemle (2) 45. 


\section{A fordítókkal készült interjúk:}

Nagy Kálmánnal:

KOCSIS István: Új Kalevala-fordítás. Ifjúmunkás 1967. XII. 31.

Rácz Istvánnal:

Daloljuk dalunkat együtt. Beszélgetés Rácz Istvánnal a Kalevaláról. Somogy 1985/1, 54-67.

BANOS János: Fényképek, fák, fordítások. Helsinki beszélgetés Rácz Istvánnal. Élet és Irodalom 1986. júl. 18. 7.

Szente Imrével:

Európa és az elsüllyedt Atlantisz. In: DÁVID Gyula - VERESS Zoltán (szerk.): Határtalan hazában. Ezredfordulós töprengések. EKE, Stockholm, 2000, 78-111.

\section{Lexikonok:}

Magyar Katolikus Lexikon. Szt. István Társulat, Apostoli Szentszék, Budapest, 1993.

Magyar Néprajzi Lexikon. Akadémiai, Budapest, 1977.

DOMOKOS Péter (szerk.): Finnugor Életrajzi Lexikon. Budapest, 1990.

\section{Bibliográfiák:}

JÁVORI Jenő

1975 A finnugor népek irodalmának bibliográfiája. Fővárosi Szabó Ervin Könyvtár, Budapest.

1995 Az uráli népek irodalmának bibliográfiája. (1975-1994) Berzsenyi

Dániel Tanárképző Főiskola, Szombathely.

2004 Az uráli népek irodalmának bibliográfiája (1995-2004). Uralisztikai tanulmányok, Budapest.

TERBÓCS Attila

1999 Vikár Béla-bibliográfia. Budapesti Finnugor Füzetek, Budapest. 



\section{MELLÉKLETEK}

\section{1. melléklet}

\section{Személy- és földrajzi nevek a forrás- és célszövegekben}

\begin{tabular}{|c|c|c|c|c|c|c|}
\hline Név & Hely & $\mathrm{BF}$ & VB & NK & RI & SzI \\
\hline Aallotar & $48: 130$ & Habtündér & Hableány & $\begin{array}{l}\text { haboknak } \\
\text { gyermeke }\end{array}$ & $\begin{array}{l}\text { hullámok } \\
\text { lányai }\end{array}$ & $\begin{array}{l}\text { vizi } \\
\text { tündér }\end{array}$ \\
\hline Ahti & & $x^{*}$ & $\mathrm{x}$ & $x$ & $x$ & $x$ \\
\hline Ahto & $48: 135 \ldots$ & $x$ & $x$ & $x$ & $x$ & $x$ \\
\hline Ahtola & $5: 19 \ldots$ & $\mathrm{x}$ & $\mathrm{x}$ & $\mathrm{x}$ & $\mathrm{x}$ & $x$ \\
\hline $\begin{array}{l}\text { Ahtolai- } \\
\text { nen }\end{array}$ & $43: 272$ & Ahto & Ahto & Ahto & Ahto & Ahto \\
\hline Ainikki & $12: 17-24$ & Annikki & Anni & $\mathrm{x}$ & $x$ & $x$ \\
\hline Aino & $4: 1-10 \ldots$ & Aina & Ajno & $\mathrm{x}$ & Ajnó & $x$ \\
\hline $\begin{array}{l}\text { Aluen- } \\
\text { järvi }\end{array}$ & $48: 29 \ldots$ & Alu tava & Alut tó & Alue tava & Határ-tó & Alue vize \\
\hline Annikki & $18: 41 \ldots$ & $\mathrm{x}$ & Anni & $\mathrm{x}$ & $\mathrm{x}$ & $x$ \\
\hline Eteletär & $32: 84 \ldots$ & Déltündér & Déltündér & $\mathrm{x}$ & Déltündér & $\begin{array}{l}\text { Dél } \\
\text { tündére }\end{array}$ \\
\hline Hongatar & $32: 85$ & $\mathrm{x}$ & Fenyőszúz & $\mathrm{x}$ & $\begin{array}{l}\text { Fenyỏtün- } \\
\text { dér }\end{array}$ & $\begin{array}{l}\text { Tülevél } \\
\text { tündér }\end{array}$ \\
\hline Hiisi & & Híz & Híszi & $\mathrm{x}$ & Híszi & $x$ \\
\hline Hiitola & $14: 327$ & Hihtola & Hísz & $x$ & Pokol/Hisz & $x$ \\
\hline Horna & $3: 172-174$ & x (bérc) & $\mathrm{x}$ & x (szikla) & x (hegy) & $x$ (szirt) \\
\hline $\begin{array}{l}\text { Hällä- } \\
\text { pyörä }\end{array}$ & $3: 179$ & $\mathrm{x}$ & Hellepüöre & $\mathrm{x}$ & Halla-örvény & $\begin{array}{l}\text { Hällä-for- } \\
\text { gatag }\end{array}$ \\
\hline Häme & $3: 179$ & Hämä & Heme & $\mathrm{x}$ & Heme & $x$ \\
\hline Imatra & $3: 181$ & $\mathrm{x}$ & $\mathrm{x}$ & $\mathrm{x}$ & Imátra & $x$ \\
\hline $\begin{array}{l}\text { Iku- } \\
\text { Turso }\end{array}$ & $42: 348 \ldots$ & Ik(k)u-Turzó & Örök-Turszó & Turso & Turszó & Turso \\
\hline Ilmatar & $1: 110 \ldots$ & lég tündére & Ilmatár & $\mathrm{x}$ & Ilmatár & $\mathrm{x}$ \\
\hline Ilpotar & $27: 71-82$ & $\mathrm{x}$ & $\mathrm{x}$ & $\mathrm{x}$ & $\mathrm{x}$ & $x$ \\
\hline Inkeri & $11: 44,55$ & $\mathrm{x}$ & Ingria & $\mathrm{x}$ & $x$ & $x$ \\
\hline Joukola & $5: 156 \ldots$ & $\mathrm{x}$ & $x$ & $\mathrm{x}$ & $x$ & $x$ \\
\hline Jumala & $2: 50 \ldots$ & Isten & Isten & Isten & Isten & isten \\
\hline
\end{tabular}

${ }^{*} \mathrm{x}=\mathrm{az}$ a forma, mely a forrásszövegben használttal hangalakilag is megegyezik. 


\begin{tabular}{|c|c|c|c|c|c|c|}
\hline $\begin{array}{l}\text { Juorta- } \\
\text { nin joki }\end{array}$ & $17: 572$ & Jordán vize & Jordán & Jordán folyó & Jordán & Jordán \\
\hline Juutas & $17: 278 \ldots$ & judás (!) & Judás & júdást (!) & Júdás & Judás \\
\hline $\begin{array}{l}\text { Kaatra- } \\
\text { koski }\end{array}$ & $3: 180$ & $\mathrm{x}$ & Kátra-koszki & $\mathrm{x}$ & Katra-selló & Katrakoski \\
\hline Kalervo & $31: 14 \ldots$ & Kalervó & Kalervo & Kalervo & Kalervó & Kalervo \\
\hline Kaleva & $2: 249 \ldots$ & Kaleva & Kalev & $\mathrm{x}$ & $\mathrm{x}$ & Kalevala \\
\hline $\begin{array}{l}\text { Kalevai- } \\
\text { nen }\end{array}$ & $4: 94 \ldots$ & Kalevai & Kalevfi & $\mathrm{x}$ & $\begin{array}{l}\text { Kaleva } \\
\text { szülöttje }\end{array}$ & Kaleva fia \\
\hline Kalevala & $3: 4 \ldots$ & $\mathrm{x}$ & $\mathrm{x}$ & $\mathrm{x}$ & $\mathrm{x}$ & Kaleva \\
\hline $\begin{array}{l}\text { Kaleva- } \\
\text { lainen }\end{array}$ & $45: 12 \ldots$ & $\begin{array}{l}\text { Kaleva } \\
\text { nemzete }\end{array}$ & $\begin{array}{l}\text { Kaleviek } \\
\text { nemzetsége }\end{array}$ & kalevalaiak & $\begin{array}{l}\text { Kaleva } \\
\text { nemzetsége }\end{array}$ & $\begin{array}{l}\text { Kaleva- } \\
\text { fiak }\end{array}$ \\
\hline $\begin{array}{l}\text { Kaleva- } \\
\text { tar }\end{array}$ & $25: 18 \ldots$ & Kalevatár & Kalevatár & $\mathrm{x}$ & Kalevatár & $\mathrm{x}$ \\
\hline Kalma & $27: 4 \ldots$ & $\begin{array}{l}\text { Kálma (föld } \\
\text { nyelve) }\end{array}$ & $\begin{array}{l}\text { vész (nyel- } \\
\text { ve) }\end{array}$ & x (nyelve) & $\begin{array}{l}\text { Kalma } \\
\text { (szája széle) }\end{array}$ & szájaszéle \\
\hline Kammo & $40: 48$ & $x$ & $x$ & $x$ & Kammó & $\mathrm{x}$ \\
\hline $\begin{array}{l}\text { Kanka- } \\
\text { hatar }\end{array}$ & $25: 428$ & $\begin{array}{l}\text { Gyolcstün- } \\
\text { dér }\end{array}$ & Kankahatár & szövő leány & szövőasszony & nők \\
\hline Karjala & $3: 180 \ldots$ & $\mathrm{x}$ & $\mathrm{x}$ & $\mathrm{x}$ & $\mathrm{x}$ & $\mathrm{x}$ \\
\hline $\begin{array}{l}\text { Karjalai- } \\
\text { nen }\end{array}$ & $20: 54$ & & & & & \\
\hline Katajatar & $32: 86$ & $\mathrm{x}$ & Borókaszúz & $\mathrm{x}$ & Borókalány & Boróka \\
\hline $\begin{array}{l}\text { Kauko- } \\
\text { niemi }\end{array}$ & $11: 8 \ldots$ & $\mathrm{x}$ & $\mathrm{x}$ & $\mathrm{x}$ & $\mathrm{x}$ & földnyelv \\
\hline Kauppi & $13: 45 \ldots$ & Kaupi & $x$ & $x$ & $\mathrm{x}$ & $x$ \\
\hline $\begin{array}{l}\text { Keitolai- } \\
\text { nen }\end{array}$ & $26: 746$ & $\mathrm{x}$ & Kejtolajnen & $\mathrm{x}$ & Kejtolajnen & Durumó \\
\hline Kemijoki & $20: 22$ & Kemi & Kémfolyó & $\mathrm{x}$ & Kemi folyó & $\begin{array}{l}\text { Kemi } \\
\text { völgye }\end{array}$ \\
\hline Kimmo & $40: 48$ & $\mathrm{x}$ & $\mathrm{x}$ & $\mathrm{x}$ & Kimmó & $\mathrm{x}$ \\
\hline $\begin{array}{l}\text { Kipumä- } \\
\text { ki, Kipu- } \\
\text { vuori }\end{array}$ & $\begin{array}{l}45: 297- \\
298\end{array}$ & $\begin{array}{l}\text { Betegség- } \\
\text { domb, } \\
\text { Betegség- } \\
\text { hegy }\end{array}$ & $\begin{array}{l}\text { Kórság- } \\
\text { domb, } \\
\text { Kórsághegy }\end{array}$ & $\begin{array}{l}\text { kórsághegy, } \\
\text { bánatdomb }\end{array}$ & $\begin{array}{l}\text { Kórok } \\
\text { köve, Kínok } \\
\text { hegye }\end{array}$ & $\begin{array}{l}\text { Kínhalom, } \\
\text { Fájdalom- } \\
\text { hegy }\end{array}$ \\
\hline $\begin{array}{l}\text { Kiputyttö, } \\
\text { Kivutar }\end{array}$ & $45: 26,282$ & $\begin{array}{l}\text { Kórsellő, } \\
\text { Kórtündér }\end{array}$ & Kórleány & $\begin{array}{l}\text { kórság } \\
\text { lánya, kín } \\
\text { tündére }\end{array}$ & $\begin{array}{l}\text { Kiputár, } \\
\text { Kór tündére }\end{array}$ & $\begin{array}{l}\text { Kín-kisasz- } \\
\text { szony, } \\
\text { Kín-anyó }\end{array}$ \\
\hline Kuippana & $32: 493$ & $\mathrm{x}$ & Nyurganyak & $\mathrm{x}$ & Kujppana & $\mathrm{x}$ \\
\hline Kuura & $30: 50,94$ & Kúra & Kúra & $x$ & Kúra & Kuura \\
\hline Kuutar & $4: 135 \ldots$ & $\begin{array}{l}\text { Hold tündé- } \\
\text { re, Kúntár }\end{array}$ & holdtündér & Hold leánya & $\begin{array}{l}\text { Hold- } \\
\text { tündér, } \\
\text { Holdlány }\end{array}$ & $\begin{array}{l}\text { Hold- } \\
\text { leány }\end{array}$ \\
\hline Kuutola & $11: 36$ & Hold laka & Holdföld & $\begin{array}{l}\text { Hold } \\
\text { országa }\end{array}$ & - & $\begin{array}{l}- \\
\text { (körülírás) }\end{array}$ \\
\hline $\begin{array}{l}\text { Lappa- } \\
\text { lainen }\end{array}$ & $3: 22 \ldots$ & Lapphoni fi & $\begin{array}{l}\text { lapp } \\
\text { legényke }\end{array}$ & lapp legény & lapp legény & lapp legény \\
\hline Lappi & $7: 43 \ldots$ & Lappföld & $\begin{array}{l}\text { Lappok } \\
\text { lakta }\end{array}$ & Lappország & lapp lapály & $\begin{array}{l}\text { lappok } \\
\text { határa }\end{array}$ \\
\hline $\begin{array}{l}\text { Lem- } \\
\text { menlahti }\end{array}$ & $18: 548 \ldots$ & Lempi öble & Szépszoros & Gyöngyöböl & $\begin{array}{l}\text { Szerelem- } \\
\text { öböl }\end{array}$ & Örömöböl \\
\hline
\end{tabular}




\begin{tabular}{|c|c|c|c|c|c|c|}
\hline $\begin{array}{l}\text { Lem- } \\
\text { minkäi- } \\
\text { nen }\end{array}$ & & & & & & \\
\hline Lempo & $6: 38$ & Lempó & x (ördög) & $\mathrm{x}$ & Lempó & x (ördög) \\
\hline Lokka & $\begin{array}{l}25: 17- \\
26 \ldots\end{array}$ & $\mathrm{x}$ & $\mathrm{x}$ & $x$ & $\mathrm{x}$ & $\mathrm{x}$ \\
\hline Loviatar & $\begin{array}{l}45: 23- \\
86 \ldots\end{array}$ & $\mathrm{x}$ & $\mathrm{x}$ & $x$ & $\begin{array}{l}\text { Loviatár } \\
\text { (undok } \\
\text { lotyó) }\end{array}$ & $\begin{array}{l}\text { Alvilág } \\
\text { réme, } \\
\text { rimája }\end{array}$ \\
\hline Luonnotar & $1: 112 \ldots$ & lég leánya & ég leánya & ég leánya & $\begin{array}{l}\text { levegőég } \\
\text { lánya }\end{array}$ & $\begin{array}{l}\text { egek } \\
\text { lánya }\end{array}$ \\
\hline Luotola & $7: 67$ & x (öble) & $\mathrm{x}$ & x (öble) & $\begin{array}{l}\text { Luoto } \\
\text { (öble) }\end{array}$ & Luotala \\
\hline Lyylikki & $13: 46 \ldots$ & Lülikki & Lülikki & $\mathrm{x}$ & Lülikki & $\mathrm{x}$ \\
\hline Manala & $6: 127 \ldots$ & alvilág & Manólaka & $x$ & $\begin{array}{l}\text { Mana } \\
\text { hajloka }\end{array}$ & $\begin{array}{l}\text { Mana, } \\
\text { Manala }\end{array}$ \\
\hline Manalatar & $16: 288$ & $\begin{array}{l}\text { Alvilági } \\
\text { öreg } \\
\text { asszony }\end{array}$ & $\begin{array}{l}\text { Mana-tün- } \\
\text { dérje } \\
\text { (agg-csont) }\end{array}$ & $\begin{array}{l}\text { manalai } \\
\text { asszony }\end{array}$ & Manalatár & $\begin{array}{l}\text { alvilág } \\
\text { anyója }\end{array}$ \\
\hline $\begin{array}{l}\text { Manatar } \\
\text { (ilkein) }\end{array}$ & $45: 26$ & $\begin{array}{l}\text { Mánutarok } \\
\text { legrosz- } \\
\text { szabbja }\end{array}$ & $\begin{array}{l}\text { Manatündé- } \\
\text { rek silánya }\end{array}$ & $\begin{array}{l}\text { pokolleg- } \\
\text { hitványabb } \\
\text { lánya }\end{array}$ & $\begin{array}{l}\text { Mana } \\
\text { leggon- } \\
\text { noszabb } \\
\text { lánya }\end{array}$ & $\begin{array}{l}\text { Bajba } \\
\text { bájoló } \\
\text { boszorka }\end{array}$ \\
\hline Melatar & $40: 71$ & $\begin{array}{l}\text { Kormány } \\
\text { tündér }\end{array}$ & $\begin{array}{l}\text { Zúgótői } \\
\text { kisasszony }\end{array}$ & $\begin{array}{l}\text { Zuhatag } \\
\text { széli kisasz- } \\
\text { szony }\end{array}$ & $\begin{array}{l}\text { Melatár } \\
\text { (tündér) }\end{array}$ & $\begin{array}{l}\text { Kormá- } \\
\text { nyos } \\
\text { tündér }\end{array}$ \\
\hline Metsola & $14: 136 \ldots$ & Metzola & Erdőtáj & $\mathrm{x}$ & Metszola & $\mathrm{x}$ \\
\hline Mielikki & $32: 89$ & $\mathrm{x}$ & $x$ & $x$ & $x$ & $x$ \\
\hline Mimerkki & $14: 217$ & Mimerki & $x$ & $x$ & $x$ & $x$ \\
\hline $\begin{array}{l}\text { Nevan } \\
\text { joki }\end{array}$ & $\begin{array}{l}47: 139- \\
140\end{array}$ & Néva vize & nagy Néva & Néva vize & Néva folyó & Néva vize \\
\hline Nyyrikki & $14: 37 \ldots$ & Nürikki & Nürikki & $x$ & Nürikki & $x$ \\
\hline $\begin{array}{l}\text { Nälkäni- } \\
\text { emi }\end{array}$ & $30: 327$ & éhség-csúcs & $\begin{array}{l}\text { Éhség félszi- } \\
\text { getje }\end{array}$ & Éhség földje & Éhségfalva & $\begin{array}{l}\text { Sanyarúfé- } \\
\text { szek }\end{array}$ \\
\hline $\begin{array}{l}\text { Osmo, } \\
\text { Osmoinen }\end{array}$ & $10: 20 \ldots$ & Oszma & Oszmó & $\mathrm{x}$ & Oszmó & $x$ \\
\hline Osmola & $7: 98$ & $\begin{array}{l}\text { Oszmó } \\
\text { berke }\end{array}$ & Oszmola & $x$ & Oszmola & $x$ \\
\hline Osmotar & $23: 5 \ldots$ & Ozmotar & Oszmotár & $x$ & Oszmotár & $x$ \\
\hline Otavatar & $24: 83$ & Ottavatar & Göncöllány & Göncölleány & $\begin{array}{l}\text { Göncöl } \\
\text { lánya }\end{array}$ & Ég tündére \\
\hline $\begin{array}{l}\text { Pakkanen, } \\
\text { Pakko }\end{array}$ & $30: 124 \ldots$ & Fagy & Fagyfiú & Fagyocska & Fagy-úrfi & Fagy-fia \\
\hline $\begin{array}{l}\text { Palvoi- } \\
\text { nen }\end{array}$ & $20: 72 \ldots$ & $\mathrm{x}$ & Palvojnen & $x$ & Palvojnen & $x$ \\
\hline $\begin{array}{l}\text { Peller- } \\
\text { voinen }\end{array}$ & $2: 13 \ldots$ & Pellervo & Pellervojnen & $x$ & Pellervó & $x$ \\
\hline $\begin{array}{l}\text { Pihlaja- } \\
\text { tar }\end{array}$ & $32: 87$ & $\mathrm{x}$ & $\begin{array}{l}\text { berkeny- } \\
\text { eszüz }\end{array}$ & $x$ & $\begin{array}{l}\text { Berkenye- } \\
\text { szűz }\end{array}$ & Berkenye \\
\hline Piltti & $50: 205 \ldots$ & Pilti & $\mathrm{x}$ & $x$ & $\mathrm{x}$ & Pilttike \\
\hline $\begin{array}{l}\text { Pimen- } \\
\text { tola }\end{array}$ & $6: 92 \ldots$ & $\mathrm{x}$ & Homályhon & $x$ & Északföld & Éj hona \\
\hline Piru & $23: 748$ & ördöng(ös) & ördögfi & $\begin{array}{l}\text { ördög/go- } \\
\text { nosz }\end{array}$ & $\begin{array}{l}\text { ördög/po- } \\
\text { kol fajzat }\end{array}$ & ördög \\
\hline
\end{tabular}




\begin{tabular}{|c|c|c|c|c|c|c|}
\hline Pisa & $3: 171-173$ & Písza hegy & Písza & $\mathrm{x}$ (halma) & Písza & $\mathrm{x}$ \\
\hline $\begin{array}{l}\text { Pohja, } \\
\text { Pohjola, } \\
\text { Pohjonen }\end{array}$ & $1: 20,35 \ldots$ & $\mathrm{x}$ & $\begin{array}{l}\text { Észak } \\
\text { hajléka }\end{array}$ & $\mathrm{x}$ & $\begin{array}{l}\text { Észak } \\
\text { hajléka }\end{array}$ & $\mathrm{x}$ \\
\hline Puhuri & $\begin{array}{l}30: 185 \\
299\end{array}$ & $\begin{array}{l}\text { Ejszaki szél } \\
\text { fia }\end{array}$ & Fujó fattya & $\mathrm{x}$ & Vihar fia & Zimankó \\
\hline Päivälä & $11: 32$ & - & Napföld & Nap országa & Nap háza & - \\
\hline Päivätär & $4: 136 \ldots$ & $\begin{array}{l}\text { Nap tün- } \\
\text { dére }\end{array}$ & $\begin{array}{l}\text { naptün- } \\
\text { dérke }\end{array}$ & Nap leánya & $\begin{array}{l}\text { Napnak } \\
\text { szüze, } \\
\text { Napleány, } \\
\text { Nap tündére }\end{array}$ & $\begin{array}{l}\text { Napkis- } \\
\text { asszony, } \\
\text { Naplány }\end{array}$ \\
\hline $\begin{array}{l}\text { Remu- } \\
\text { nen }\end{array}$ & $20: 143$ & Remu fia & $\begin{array}{l}\text { kedvnek } \\
\text { a fia }\end{array}$ & jókedv fia & $\begin{array}{l}\text { mámor } \\
\text { gyermeke }\end{array}$ & kedv fattya \\
\hline Ruotsi & $20: 78$ & Svédhon & Svédország & $\begin{array}{l}\text { svédek } \\
\text { birtokai }\end{array}$ & $\begin{array}{l}\text { svédek } \\
\text { hona }\end{array}$ & $\begin{array}{l}\text { viking } \\
\text { haza }\end{array}$ \\
\hline Ruotus & $50: 237 \ldots$ & Ruotusz & Ruotusz & $\mathrm{x}$ & Ruotusz & $x$ \\
\hline $\begin{array}{l}\text { Rutjan } \\
\text { koski }\end{array}$ & $12: 463 \ldots$ & $\begin{array}{l}\text { Rutja } \\
\text { forgója }\end{array}$ & Rutja zúgója & $\begin{array}{l}\text { rutjai víz- } \\
\text { esés }\end{array}$ & $\begin{array}{l}\text { Rutja } \\
\text { örvénye }\end{array}$ & $\begin{array}{l}\text { Rutja } \\
\text { zúgója }\end{array}$ \\
\hline \multicolumn{7}{|l|}{$\begin{array}{l}\text { Saarelai- } \\
\text { nen }\end{array}$} \\
\hline Saari & $\begin{array}{l}11: 21- \\
22 \ldots\end{array}$ & szári & Szári & $\mathrm{x}$ & Sziget & Sziget \\
\hline Saksa & $18: 137 \ldots$ & Német & szász & németföld & $\begin{array}{l}\text { Szászor- } \\
\text { szág }\end{array}$ & $\begin{array}{l}\text { hetedhét- } \\
\text { ország }\end{array}$ \\
\hline \multicolumn{7}{|l|}{ Sampo } \\
\hline Sampsa & & $\mathrm{x}$ & $\mathrm{x}$ & $\mathrm{x}$ & $\mathrm{x}$ & $\mathrm{x}$ \\
\hline Saraoja & $50: 208 \ldots$ & Szára-víz & Sásér & Saraja & Szaraja & $\mathrm{x}$ \\
\hline Sariola & $8: 20 \ldots$ & Száriola & Szárjola & $\mathrm{x}$ & Száriola & $x$ \\
\hline Savo & $\begin{array}{l}35: 352, \\
48: 257\end{array}$ & Szávola & Szavó & $\mathrm{x}$ & Szavó & Salo \\
\hline Simasalo & $18: 550 \ldots$ & Szimai fok & Osöböl & Mézerdő & Mézerdő & Mézmezỏ \\
\hline Sinetär & $25: 427$ & Kéktündér & Szineter & festő leány & $\begin{array}{l}\text { kékfestö } \\
\text { lány }\end{array}$ & nỏk \\
\hline Sotkotar & $41: 143$ & Kacsa-sellỏ & Kacsatündér & Kacsatündér & $\begin{array}{l}\text { Kácsatün- } \\
\text { dérek }\end{array}$ & Récenővér \\
\hline Suolasalmi & $46: 313$ & sófok & Só-szoros & sóvidék & Só-szoros & $\mathrm{x}$ \\
\hline $\begin{array}{l}\text { Suoma- } \\
\text { lainen }\end{array}$ & $20: 36$ & Szuomi & $\begin{array}{l}\text { Finn- } \\
\text { ország(nak) }\end{array}$ & $\begin{array}{l}\text { Finn- } \\
\text { ország(nak) }\end{array}$ & finnek & finn \\
\hline Suomela & $18: 59$ & Szuomi & Szuomi & $\mathrm{x}$ & finn & $\mathrm{x}$ \\
\hline Suomi & $20: 18 \ldots$ & $\begin{array}{l}\text { Szuomi-or- } \\
\text { szág }\end{array}$ & Finnország & Finnország & Szuomi & $\mathrm{x}$ \\
\hline Suonetar & $15: 316$ & Szuonetár & Erek anyja & $\mathrm{x}$ & Szuonetár & $\begin{array}{l}\text { Érhez értỏ } \\
\text { tündérasz- } \\
\text { szony }\end{array}$ \\
\hline Suovakko & $18: 579$ & Szuovako & Szuovakko & $\mathrm{x}$ & Szuovakkó & szüle \\
\hline Suvantola & $6: 233$ & Szuvantola & Szuvantola & $\mathrm{x}$ & Szuvantola & Suvanto \\
\hline $\begin{array}{l}\text { Suvanto- } \\
\text { lainen }\end{array}$ & $6: 62 \ldots$ & Szuvantai & Szuvantói & $\mathrm{x}$ & Szuvantói & Suvanto fia \\
\hline Surma & $13: 153 \ldots$ & Vész torka & Halál & halál szája & Pokol torka & Halál ajka \\
\hline Suvetar & $32: 83 \ldots$ & $\begin{array}{l}\text { Nyár } \\
\text { tündére }\end{array}$ & Nyártündér & $\mathrm{x}$ & Nyártündér & $\begin{array}{l}\text { Nyártün- } \\
\text { dér }\end{array}$ \\
\hline Syöjätär & $15: 595 \ldots$ & Szúöjätär & Szüöjeter & $x$ & Szüöjeter & $x$ \\
\hline $\begin{array}{l}\text { Taka- } \\
\text { lappi }\end{array}$ & $3: 170$ & lappföldi & $\begin{array}{l}\text { Felső } \\
\text { Lapphon }\end{array}$ & $\begin{array}{l}\text { Lappok } \\
\text { földje }\end{array}$ & észak népe & lapp \\
\hline $\begin{array}{l}\text { Tanikan } \\
\text { linna }\end{array}$ & $25: 613$ & $\begin{array}{l}\text { Tanikka } \\
\text { vára }\end{array}$ & Tanikkai vár & tanikkai vár & Tallinn vára & $\begin{array}{l}\text { Tanikka } \\
\text { vára }\end{array}$ \\
\hline Tapio & $32: 88 \ldots$ & $\mathrm{x}$ & $\mathrm{x}$ & $\mathrm{x}$ & Tapió & $\mathrm{x}$ \\
\hline
\end{tabular}




\begin{tabular}{|c|c|c|c|c|c|c|}
\hline Tapiola & $14: 25 \ldots$ & Tápjola & $\mathrm{x}$ & $\mathrm{x}$ & Tapió háza & $x$ \\
\hline $\begin{array}{l}\text { Tapi- } \\
\text { omäki }\end{array}$ & $50: 304$ & Tápjó-hegyi & Tapio-domb & Tapio hegy & Tapió ólja & Tapiola \\
\hline Tellervo & $32: 90 \ldots$ & $\mathrm{x}$ & $x$ & $\mathrm{x}$ & $x$ & $x$ \\
\hline Tiera & $30: 49 \ldots$ & $\mathrm{x}$ & $\mathrm{x}$ & $\mathrm{x}$ & $\mathrm{x}$ & $x$ \\
\hline Tuonetar & $32: 88$ & $x$ & zelniceszüz & $\mathrm{x}$ & Zelnice & Zelnice \\
\hline $\begin{array}{l}\text { Tuomi- } \\
\text { vaara }\end{array}$ & $32: 310$ & $\begin{array}{l}\text { Zelnicze } \\
\text { vár? }\end{array}$ & - & - & $\begin{array}{l}\text { Zelniceha- } \\
\text { lom? }\end{array}$ & - \\
\hline Tuonela & $17: 3 \ldots$ & Halál-lak & $\mathrm{x}$ & $\mathrm{x}$ & $x$ & $x$ \\
\hline $\begin{array}{l}\text { Tuonen } \\
\text { joki }\end{array}$ & $16: 161 \ldots$ & $\begin{array}{l}\text { Halál } \\
\text { folyója }\end{array}$ & Tuonela vize & $\begin{array}{l}\text { Tuonela } \\
\text { folyója }\end{array}$ & Touni árja & $\begin{array}{l}\text { Tuonela } \\
\text { tava }\end{array}$ \\
\hline $\begin{array}{l}\text { Tuonen } \\
\text { tyttö }\end{array}$ & $16: 163 \ldots$ & Halál szúze & Tuoni szüze & Tuoni lánya & Tuoni lánya & $\begin{array}{l}\text { Tuoni } \\
\text { lánya }\end{array}$ \\
\hline Tuoni & $12: 156 \ldots$ & Halál & $x$ & $\mathrm{x}$ & $x$ & $x$ \\
\hline Turja & $20: 80 \ldots$ & $\mathrm{x}$ & Turjaföld & $\mathrm{x}$ & $\mathrm{x}$ & $x$ \\
\hline $\begin{array}{l}\text { Turjalai- } \\
\text { nen }\end{array}$ & $12: 138 \ldots$ & turjalai & Turja & turjai & Turja fiai & Turja-béli \\
\hline Tursas & $2: 67$ & Turszasz & Turszász & $\mathrm{x}$ & Turszász & $x$ \\
\hline Tuulikki & $14: 174$ & Tullikki & Túlikki & $\mathrm{x}$ & Túlikki & $x$ \\
\hline Tuuri & $47: 185 \ldots$ & Túri & Túr & $\mathrm{x}$ & Turi & $x$ \\
\hline $\begin{array}{l}\text { Tyrjä(n } \\
\text { koski) }\end{array}$ & $9: 378$ & Türje & $\begin{array}{l}\text { Türje } \\
\text { zuhogója }\end{array}$ & Turja vize & Türje habja & $\mathrm{x}$ \\
\hline Tähetär & $24: 84$ & Tähettär & Csillaglány & Csillagleány & $\begin{array}{l}\text { csillag } \\
\text { lánya }\end{array}$ & $\begin{array}{l}\text { Csillagtün- } \\
\text { dér }\end{array}$ \\
\hline Tähtelä & $11: 40$ & Csillag laka & Csillag-rét & $\begin{array}{l}\text { Csillag } \\
\text { országa }\end{array}$ & $\begin{array}{l}\text { Csillag } \\
\text { háza }\end{array}$ & - \\
\hline $\begin{array}{l}\text { Ukko } \\
\text { yliju- } \\
\text { mala }\end{array}$ & $14: 13 \ldots$ & $\begin{array}{l}\text { Ukko, te } \\
\text { legfőbb } \\
\text { isten }\end{array}$ & $\begin{array}{l}\text { Ukko, te } \\
\text { felső isten }\end{array}$ & $\begin{array}{l}\text { Uram, } \\
\text { Ukko, fönti } \\
\text { isten }\end{array}$ & $\begin{array}{l}\text { Öreg Ukkó, } \\
\text { örök Isten }\end{array}$ & $\begin{array}{l}\text { Világnak } \\
\text { ura, nagy } \\
\text { Ukko, } \\
\text { Miatyánk } \\
\text { magas } \\
\text { egekben }\end{array}$ \\
\hline Ulappala & $45: 32$ & sivatag? & álomházi? & $\begin{array}{l}\text { tengeror- } \\
\text { szág? }\end{array}$ & - & - \\
\hline Untamo & $5: 17 \ldots$ & $\mathrm{x}$ & $x$ & $\mathrm{x}$ & Untamó & $x$ \\
\hline $\begin{array}{l}\text { Untamola, } \\
\text { Untola }\end{array}$ & $31: 99 \ldots$ & $\begin{array}{l}\text { Untam' } \\
\text { háza }\end{array}$ & Untamóék & $\begin{array}{l}\text { Untamóék, } \\
\text { Untamo } \\
\text { emberei }\end{array}$ & Untamóék & Untamo \\
\hline Uusilinna & $25: 614$ & Ujvár & új vár & új város & újvár & új város \\
\hline $\begin{array}{l}\text { Uutar, } \\
\text { Ututyttö }\end{array}$ & $\begin{array}{l}42: 337- \\
338 \ldots\end{array}$ & $\begin{array}{l}\text { Ködtündér, } \\
\text { párák szüze }\end{array}$ & $\begin{array}{l}\text { Ködkis- } \\
\text { asszony, } \\
\text { Páratündér }\end{array}$ & $\begin{array}{l}\text { Köd } \\
\text { tündére, } \\
\text { Terhenetär }\end{array}$ & $\begin{array}{l}\text { Köd leánya, } \\
\text { Páratündér }\end{array}$ & $\begin{array}{l}\text { Homály } \\
\text { hölgye, } \\
\text { Ködkisasz- } \\
\text { szony }\end{array}$ \\
\hline $\begin{array}{l}\text { Uvanto- } \\
\text { lainen }\end{array}$ & $7: 242 \ldots$ & $\begin{array}{l}\text { Uvautolai- } \\
\text { nen }\end{array}$ & $\begin{array}{l}\text { Uvantolaj- } \\
\text { nen }\end{array}$ & $\mathrm{x}$ & Uvantó ura & $\begin{array}{l}\text { Uvanto } \\
\text { sarja }\end{array}$ \\
\hline Vammatar & $45: 283$ & Sérvtündér & Sebleány & seb asszonya & Vammatár & Sérv-anyóka \\
\hline Vellamo & $5: 20 \ldots$ & Vellám & $\mathrm{x}$ & $\mathrm{x}$ & Vellamó & vízi lányok \\
\hline Venäjä & $31: 9 \ldots$ & $\begin{array}{l}\text { Orosz } \\
\text { Dvina }\end{array}$ & muszkaföld & $\begin{array}{l}\text { oroszok } \\
\text { országa }\end{array}$ & muszkaföld & $\begin{array}{l}\text { oroszok } \\
\text { országa }\end{array}$ \\
\hline Vesihiisi & $12: 262$ & Vizi Hizi & Viz ördöge & vízördög & $\begin{array}{l}\text { Vizek } \\
\text { szörnye }\end{array}$ & víziszellem \\
\hline Vetehinen & $\begin{array}{l}19: 217 \\
26: 694\end{array}$ & Vizi szörny & Vizi ördög, x & Vizördög & $\begin{array}{l}\text { Vízi ördög, } \\
x\end{array}$ & $\begin{array}{l}\text { víz } \\
\text { manója, } x\end{array}$ \\
\hline Vipunen & $1: 49$ & $\mathrm{x}$ & $\mathrm{x}$ & $\mathrm{x}$ & $\mathrm{x}$ & $x$ \\
\hline Viro & $11: 43 \ldots$ & $\mathrm{x}$ & Észtország & Észtország & Észtország & $x$, Eszt \\
\hline
\end{tabular}




\begin{tabular}{|l|l|l|l|l|l|l|}
\hline $\begin{array}{l}\text { Virokan- } \\
\text { nas }\end{array}$ & $20: 54 \ldots$ & $\begin{array}{l}\text { Virókán- } \\
\text { nász, Viro- } \\
\text { kannasz }\end{array}$ & Virókánnász & $\mathrm{x}$ & $\begin{array}{l}\text { Virókan- } \\
\text { nász }\end{array}$ & $\mathrm{x}$ \\
\hline Vuoksi & $3: 181 \ldots$ & Vuokszi & Voukszi (!) & $\mathrm{x}$ & Vuokszi & $\mathrm{x}$ (vízesése) \\
\hline Väinölä & $3: 3 \ldots$ & $\mathrm{x}$ & vejnöhon & $\mathrm{x}$ & Vejnöle & $\mathrm{x}$ \\
\hline
\end{tabular}

\section{2. melléklet}

\section{Az elő- és utóhang magyarul és finnül}

\section{Barna Ferdinánd fordítása (1871)}

Hajt a lélek, nagy a kedvem,

Gondolatom unszol engem,

Fognom dalhoz, énekléshez,

Kezdenem a regéléshez,

Hadak sorát levezetnem,

Nemzetségdalt énekelnem;

Számban a szók olvadoznak,

A mondatok omladoznak,

Nyelvem hegyén hullámzanak,

Fogaim közt rést keresnek.

Arany felem játszó-társom,

Velem együtt nőtt korácsom!

Jöszte velem énekelni,

Velem együtt regélgetni,

Miután most összejutánk,

Szerte hosszan jártunk után;

Ugy is ritkán találkozunk,

Össze ritkán akadhatunk,

E nyomoru határokon,

Pohjolai bús tájákon.

Kezeinket csapjuk egybe,

Ujjainkat füzzük össze,

Valami jót énekelnünk,

A legjavát előszednünk,

Hallhatni a rávágyóknak,

Aranynál is drágábbaknak,

A növekvő ifjuságban,

Fejledező ivadékban, 
A fennmaradt büv-dalokat, Szájon forgó vers-szakokat Agg Vainőnek az övéről, Ilmarinen műhelyéről, Kaukomieli kardhegyéről, Joukaha nyila ösvényéről, Pohja szántóföldeiről, Kalevala mezeiről.

Ezt éneklé jó atyácskám

Fejsze-nyelét faragcsálván, Taníta rá édes szülém Orsó szárát peregtetvén, Midőn neki kiskoromban Térde előtt forgolódtam Mind fejődő nyáskálódó Kis pendikés anyás fiu. Szampóról nem hiányoztak, Sem Louhiról a büvszavak: szampó dalban vénüle el, Louhit varázs emészté fel, Dalban hala meg Vipunen, Lemminkäinen játék közben.

Vannak ezen kivül igék, Bűvszók miket tanulgaték, Tépegetve az utfélről, Szaggatva a hangafüről, Bokrokról is tépegettem, Fák galyáról tördelgettem, Dörzsölgettem füfejekről, Felszedtem az utszélekről, Kis bojtárként járkeltemben, A mint nyájam legeltettem, A mézgazdag halmocskákon Kies arany dombocskákon, Nyomán barna Múrikkinknak Mi iromba jó Kimmónknak.

Dalt sugalt a fagy is nekem, Dal hult alá az esőben, Másokat a szelek hoztak, 
Tengerhabok azt hajtottak,

A madárkák gazdagíták,

Fák teteji gyarapíták.

Mindmegannyit összegyưjtém

Göngyölegbe kötözgetém;

Szánkára a göngyöleget,

Szánra tevém a tekercset;

Vivém szánkán hazafelé,

Kis szánomon a csürbe bé,

Onnan a csür údarára,

Betevém ott rézládába.

Verseim már a hidegben,

Rég hevernek a rejtekben;

Elő vegyem-e a fagyból,

Verseim a húvös helyről,

Behozzam a házba ide,

Ládámat a lócza végre,

Alá e szép fedélzetnek,

E kitúnő tetőzetnek;

Dalszekrényem kinyissam-e,

Verses ládám feltárjam-e,

Felbontsam-e a nyalábot,

Felbontsam-e rajt' a csomót?

Szép dalt fogom én zengeni, Szép verseket énekelni

A jeles rozs eledeltől,

A jó ízú árpa sörtől:

Ám ha nekem sört nem adnak,

Ha még lörét sem nyujtanak,

Böjtösb szájjal dalolgatok,

Puszta víznél dúdogatlok,

A mai est örömére,

E szép napnak a dicsére,

Vígságára a holnapnak,

Kezdetére az uj napnak. 
Ajkim immár be kén' tennem, Nyelvemet lebilincselnem, Énekemet félbehagynom, Megszüntetnem vidám dalom;

Pihenni a ló is kiván, Hosszas utat járta után, Elvásik a vas is maga, Ha sok szénát kaszált vala, Víztömeg is alázuhan, Vízesésnél a folyóban, A tüznek is hamvadni kell, Ha lobogott egész éjjel: Mért csupán az ének maga, A gyönge dal ne lankadna, Az est hosszú élve után, A verőfény leáldozván!

Sokszor hallék ily besszédet, Más felől így vélekedtek: „Még maga a zuhatag sem Adja vizét ki egészen, A jó dalnok se fogja mind Sorba zengni a dalait; Jobb azt inkább abba hagyni, Semmint közben megszakadni."

Ekként kezdve, bevégezve, Elvégezve, berekesztve, Dalaimat egy tekercsbe, Göngyölegbe kötözöm be, Teszem kamrám rejtekébe, Csontládám legbelsejébe Honnan soha ki sem jönnek, Semmikép' sem menekülnek, A csontnak megingta nélkül, Államnak szétnyilta nélkül, Míg fogaim szét nem válnak, Nyelvem át a gáton nem hat.

Mit is érne egyre zengnem, Összevissza énekelnem, 
Dalaimmal minden völgyet, Betöltnöm a fenyv erdőket?

Anyám oda, élni megszűnt, Jó szülőm nem virraszt velünk, Nincsen babám, nincs kedvesem, Dalra vágyó szerelmesem;

Csak a fenyők figyelnek rám.

Fenyőágak hallják danám, Részvéttel a nyírek vannak, A berkenyefák hallgatnak.

Kicsiny valék, hogy anyámtól, Elmaradtam hủ dajkámtól, Mint pacsirta a hegyeken, Húros madár a bérczeken, Idegen nő gyámságában, Mostohámnál ápolásban; Ez engem' kis árva fiut, Kikergete gyönge korút A ház szeles külrészébe, Legéjszakibb hüs szélére A széltől elsepertetnem, Kisded árvafinak nekem.

Mint pacsirta kezdék szállni, Árva madár kelni-járni, Kicsinyke már földön futni, És nyavalyás barangolni, A szeleket felismernem, A közel vészt észrevennem, Dérben, fagyban dideregnem, Jajongnom nagy hidegekben.

Akadnak most már elegen, Vannak most már nagy felesen, Zok szavakkal leszidóim, Oktalanul gáncsolóim; Ki nyelvemet kárhoztatja, Ki hangomat hibáztatja, Majd rekedtnek szidalmazván, 
Majd dalaim megsokalván,

Állítván, hogy rosszul zengek,

Fordulatot, hibást teszek.

Kár a felett, jó emberek,

Oly igen megütköznetek,

Hogy én gyermek sokat zengek,

Ifjan roszul mért csicsergek:

Nem voltam én tanulásban,

Nagy urakkal társalgásban,

Nem hallottam idegen szót,

Távolabbról semmi hangot.

Tanulhattak mások, én nem,

Csupán én nem menekhettem

Jó anyámnak oldalától,

Egyetlenem szárnya alól,

Otthon kelle nevelésem

Ön házunknál megszereznem,

Édes anyám guzsalyánál,

Bátyám faragó padjánál,

Még parányi gyerekenten,

Ringyes-rongyos ingecskémben,

De hát mégis, mindazáltal,

Utat törtem dalaimmal,

Utat törtem, mutatgattam,

Galyat téptem, irtogattam;

Az uj ösvény itt kezdődik,

Az uj pálya innen nyílik,

Termékenyebb dalszerzőknek,

Tehetségesb versköltőknek

A növekvő nemzedékben,

Az ifiú nemzetségben. 


\section{Vikár Béla fordítása (1935)}

Mostan kedvem kerekedik,

Elmém azon töprenkedik,

Hogy ím dalra kéne kelni,

Ideje volna énekelni,

Nemek nótáit dudolni,

Fajok énekeit fujni;

Szavaim szétolvadnak számban,

Beszédim buzognak bátran,

Nyelvemre sietnek sürün,

Fogaimra folyton folynak.

Édes játom, jó barátom,

Gyermekkori gyöngy korácsom!

Jer ide, énekeljünk eggyütt,

Kettesben a kántust kezdjük,

Most hogy újra összejöttünk,

Két felől ide kerültünk,

Ritkán is jövünk így össze,

Látjuk egymást szemtül-szembe

Mi szegény hazánk határán,

Pusztaságos Pohja táján.

Kéz a kézbe, kössünk öszve,

Ujjat ujjal egybefüzve,

Dalaink javára gyujtsunk,

Legis-legszépiből nyújtsunk,

Kedveseink hadd hogy hallják,

Tudnivágyók hadd tanulják

A törekvő zsenge népben,

A növekvő nemzedékben

Mind a szót, amit szereztünk,

Mind a verset, amit vettünk

Öreg Vejnö vert övéről,

Ilmár tüzhelye tövéről,

Kaukomieli kardhegyéről,

Joukahajnen jó ívéről,

Pohja földje legvégiről,

Kalevala térségiről. 
Még atyám ezeket fújta,

Fejszenyél-faragva, fúrva,

Ebbe oktatott anyuskám,

Míg orsója pörgött ujján,

Én poronty pedig a pallón,

Térde előtt forgolódtam,

Tejesképü rosszasága,

Nyálasszájú aprósága.

Szampo se volt szavak szúkiben,

Louhi se bezzeg bủbáj nélkül:

Lám szavaktól Szampo vénül,

Bűv igéken Louhi megdül,

Versekben Vipunen pusztul,

Lemminkejnen játékoktul.

Varázs-szó vagyon még más is,

Több tanúltam bűvmondás is,

Téptem őket útmentiben,

Szakítottam hangás helyen,

Tördeltem a törpe fákról,

Gyűjtöttem a gyönge ágról,

Füszálakról leszemeltem,

Falunk útján fölemeltem,

Bojtárkodva ahogy hajtám,

Fiúcska, füvellő falkám

A méztermő dombok mentén,

$\mathrm{Az}$ aranyos halmok hátán,

Barna Bojtosunk nyomában,

Mi cifra Cibók üszőnkkel.

Dalt nékem a fagy is mondott,

Éneket az eső ontott,

Más dalaim szél terelé, tenger habja hozta elé,

A madár is szókat szerzett,

Fák teteje varázsverset.

Göngyölítém egy gumóba,

Csavarítám egy csomóba;

Gumót szán mögibe dugtam,

A csomót kasomba csuktam, 
Szánkón haza szállítottam,

A pajta elé kasomban;

El is tettem csürhéjába,

Rejtettem a rézvékába.

Dalaim rég fagyon állnak, Hü lakói hűs homálynak; Hagyjam-e hidegben nótám, Kihúzzam-e fagyról kótám; Hozzam-e a házba végre, Ládikámat lócavégre, Híres ház fedele alá, Tisztes lak teteje alá, Föltárjam-e dallos táskám, Kinyissam-e verses ládám, Fölfejtsem-e gumóm bokrát.

Megoldjam-e csomóm csokrát?

Így mondhatok aztán jó dalt, Gyönyörüket fújhatok majd Egy falatka rozsfélétül, Valamicske árpalétül: Árpalét ha nem kínálnak, Még csak gyenge sört se szánnak, Szomju szájjal reákezdem, Víz mellett is megeresztem, Ránk hogy vidám este jöjjön, Nagy napunknak dísze nöjjön, Holnap is hogy kedvünk teljen, Új napunk hogy korán keljen!

Már be kéne fogni szám, Nyelvemet lekötni mán, Verselésnek végit vetni, Csendítéstőlcsendesedni; Lám a ló is fúj egy hosszút, Huzamosb utat, ha megfut; Lám kicsorbul a kaszaél, Nyáron át ha szénát metél; 
Meghalkúl a víznek útja Folyótorkolathoz jutva.

Túzláng is lelohad végre

Egész éjen által égve;

Csak a dal ne bágyadna el, Finom vers ne fáradna el,

Estén át ha örvendezett,

Naphosszat ha zengedezett?

Így hallám hogy szóval mondják,

Mástól így értém a módját:

„Zúgó is, bár dúsabb fajta, Vizét fogytig le nem hajtja,

Dallos, noha nem az alja,

Mind, amit tud, el nem dallja;

Jobb, az ész ha megmaradott,

Mint ha szerteszét szakadott."

Hát elhagyom, végit vetem, Megszakítom, megszüntetem, Gombolyagba kötöm kótám, Csomóba csavarom nótám, Csomót csür hijába dugom, Csontkamra mögé lecsukom, Honnat meg nem menekedik, Soha föl nem kerekedik Csontom megrendülte nélkül, Állam szétterülte nélkül, Fogam forgatása nélkül, Nyelvem nyargalása nélkül.

De mit ér, ha dalolok is, Ha még annyit dúdolok is, Megzengek is minden völgyet, Dalom minden fenyvest fölvet?

Rég hogy nincs anyuskám élvén, Nincs imetten agg szülécském, Nincs kedvesem, ki figyeljen, Szeretőm, ki rám ügyeljen;

Csak szömörkefák figyelnek, 
Fenyőágak rám ügyelnek,

Nyírfák gallyai kegyelnek,

Burkos berkenyék becsülnek.

Elszakadtam rég szülőmtől,

Kiskoromi nevelőmtől,

Mint pacsirta, szállva,

Mint rigó, a kőrakásra,

Panaszkodva mint pacsirta,

Rigó módra sírva-ríva,

Ismeretlen asszony telkén,

Mostohának kénye-kedvén;

Az kiüzött boldogtalant,

Hajtott gyenge gyámoltalant

Szobájából ki a szélbe,

Hajlékából északfélre,

Ott szél cibált szegénykét,

Csípett árva kis legénykét.

Mint pacsirta elbolyongtam,

Bús madárka imbolyogtam,

Földön vézna vánszorogtam,

Inség-verte vándoroltam,

Minden széllel ösmerkedtem,

Forgolódtam förgetegben,

Fázlódtam hidegben, nagyban,

Felordítottam a fagyban.

Jut is nékem most akárhány,

Találkozik több, mint várnám,

Ki haragos hangon fogad,

Szilaj hangon rám riogat;

$\mathrm{Ki}$ a nyelvem hurrogja le,

$\mathrm{Ki}$ a hangom harsogja le,

Recsegőnek szidja nótám,

Fecsegőnek mondja kótám,

Dalom durván dúdolónak,

Versem félrefordulónak.

Ne bánjátok, jámbor népek,

Rossz neven ne is vegyétek, 
Gyermekűl a dal ha gyengén, Kicsinyűl ha fúvom ferdén! Nem tanultam én azt mástól, Nem jártam tudósok telkén, Nem is kaptam szókat máshol, Büvigéket messze távol.

Mások müvelőbe mentek, Én hazulról el nem voltam, Egyetlen anyám apoltam, A magányos mellett voltam; Tanulgatni otthon kellett, Rúd alatt az éléstárban, Szülém orsócskája mellett, Bátyám szíjófája mellett, Azt is apró kis koromba, Rétümögbe rosszalkodva.

Ámde mégis, mindhiába, Csapát törtem új danákra, Csapát törtem, gallyat szeltem, Ágat nyestem, útat leltem; Innen megy az út ezentúl, Az új ösvény innen indul Dicsőbb dalok szerzőinek, Különb ének költőinek A törekvő zsenge népben, A növekvő nemzedékben. 


\section{Nagy Kálmán fordítása (1972)}

Mind csak azon gondolkodom, egyre azon elmélkedem:

Kedvem támadt énekelni, jó szívvel beszédbe fogni, népünk versét mondogatni, régiek dalát dalolni.

Szavaim számban olvadoznak, beszédeim bontakoznak, nyiladoznak nyelvem hátán, futamodnak a fogamra.

Jöjj hát, öcsém, jó barátom, gyere, gyermekkori társam! Daloljuk dalunkat együtt, ketten kezdjünk énekelni, mert most megint összegyưltünk, megérkeztünk messze földről! Ritka rend, hogy összegyüljünk, egymás látására jöjjünk ezen a szegény határon, puszta északi vidéken.

Kösd a kezedet kezembe, ujjad ujjaim közébe, jó éneket énekeljünk, legjobb dalunkat daloljuk, hallgasa meg minden jámbor, tudja meg, aki akarja, ifjú emberek sorában, növekvő népek sorában: szóljuk, ami szót szereztünk, mondjuk, ami verset vettünk öreg Väinämöinen övjén, Ilmari tüze tövében, Kaukomieli kardja élén, Joukahainen íja ívén, pohjolai rétek végén, Kalevala messze földjén.

Édesapám énekelte fejszenyél-faragás közben, 
édesanyám mondogatta orsó pergetése közben, még mikor én gyermek voltam, csak a földön forgolódtam, rossz gyerek, tejes szakállú, kis kölyök, tejfölös szájú. Szampó nem volt szavak híján, Louhi sem varázslat nélkül: Szampó a szavakba vénült, Louhi varázslatba pusztult, versekbe veszett Vipunen, Lemminkäinen játékokba.

Bőviben van még varázsszó, titkos ige, mit tanultam: szakítottam útnak szélén, téptem hangafüves téren, bokor-ágról bontogattam, hajló vesszőn hajtogattam, fü fejéről fejtegettem, kisutcán földből kivettem, míg ballagtam bojtársorban, legelőn jártam legénysorban, mézes mezőn mendegéltem, arany halmokon haladtam, fekete tehén csapásán, tarka jószágunk nyomában.

Dalaimat fagy dalolta, versemet eső üzente.

Hozta hozzám szél a verset, hajtogatta tenger habja; a madár is mondogatta, fák levele fújdogálta.

Egy csomóba csombolygattam, gombolyagba gombolygattam; csomót a szánomra tettem, kosarába kerítettem; azzal azt is hazavittem, szánnal szín elébe vittem; 
kamra padlására tettem, rézládába rejtegettem. Hidegben éltek énekeim, sokáig sötétben álltak. Hozzam-e dalom a hidegről, vegyem-e versem a fagyról, hozzam-e házunkba a ládát, letegyem-e lócavégre, híres gerendás szobában, szép tetőnek oltalmában, dalos ládám megnyissam-e, öntsem-e ki verses vékám bontsam ének gombolyagját, megoldjam-e a csomóját?

Jó dalt fogok majd dalolni, szép éneket énekelni jó falattal, rozskenyérrel, söritallal, árpalével.

De ha inni mégsem adnak, egy kis sörrel nem kínálnak, akkor szólok szűkebb szájjal, mondok verset tiszta vízzel mai esténk vígságára, nagy napunk dicsőségére, akár hajnali örömre, új reggelnek kezdetére.

Ideje számat csendesítni, nyelvem nyugalomra adni. Versem végre elnyugodjon, csengő szavam csendesedjen.

A csikók is megfáradnak, mikor hosszú útra jutnak. gyengül a kemény kasza is sűrü nyári széna szálán, elcsendesedik a víz is kanyargó mederbe jutva. elhamvad az égő tüz is 
hosszú éjen, hajnaltájban;

hogyne csendesedne versem, hogyne halkulna az ének, est elkezdett sok szóim, napnyugtától zengő versem. Így hallottam mondogatni, hallottam másokat szólni: "Nincsen olyan bő zuhatag, hogy a vize mind lefolyna, nincs olyan jó énekmondó, ki elmondjon minden verset. Jobb az észnek megmaradni, mint felébe megszakadni." Meg is állok, megpihenek, Megnyugszom, megcsendesedem.

Versemet csomóba gyüjtöm, gombolyagba gombolyítom, kamra padlására küldöm, csontos zárakkal bezárom, ki ne szabaduljon onnan, soha el ne jöjjön onnan, míg a csontom meg nem indul, míg az állam meg nem mozdul, míg a fogam ki nem fordul, míg a nyelvem meg nem perdül.

De minek is énekelni, énekelni, dalra kelni, minden völgyön énekelni, minden fenyőerdőn szólni! Nem él az én édesanyám, kedves anyám nincs közöttünk, nem is hallgatja szavamat, nem figyeli énekemet: fenyőfák figyelnek engem, hallgatnak fenyőfaágak, édesget a nyírfák lombja, becsülnek a berkenyefák.

Gyermek voltam, árva lettem, jaj, anyátlanul maradtam. 
Mint pacsirta kő közében, rigó roppant kőhalomban, mint pacsirta, úgy daloltam, mint a rigó, füttyöngettem, idegen asszony kenyerén, mostohának kedvességén.

De az elüzött magától, gyámoltalan kis gyereket házából szélnek eresztett, hazulról északra küldött, északi szél édesgetett, tavaszi szél csalogatott.

Elindultam, kis pacsirta, útnak eredtem, madárka, jajjal, búval járogattam, búval, bajjal vándoroltam, találkoztam minden széllel, ismerkedtem vad viharral; reszkettem a nagy hidegben, fáztam förtelmes fagyokban.

Sokan vannak a világon, sokan vannak, bőven vannak, kik haragos szóval szólnak, hitvány szavakkal fogadnak. Ki a nyelvemet gyalázza, ki a hangomra haragszik; zengő szavaimat szidják, énekemet megsokallják, csengő szavam csúfnak vallják, dalomat hazugnak hallják.

Ne bánjátok, jó emberek, $s$ ne haragudjatok érte, hogy én, gyermek, így daloltam, hitvány módon énekeltem! Nem jártam soha tanulni, nem éltem nagyurak mellett, nem hallottam messzi szókat, igéket idegen földön.

Mások tanulni mehettek, 
én hazulról nem mehettem, anyám segítője voltam, egyetlenem mellett éltem.

Otthon kellett csak figyelnem, tanulnom a kamra földjén, anyám orsója szavára, bátyámnak faragására, azt is amíg gyermek voltam, rongyos ingben forgolódtam.

Hanem azért mégis-mégis utat kezdtem új dalosnak, utat vágtam, ágat törtem, magam újabb útra leltem. Erre megy az út ezután, nyomomban az újabb ösvény, útja derekabb dalosnak, érdemesebb énekesnek, ifjú emberek csapása, növekvő népeknek útja.

\section{Rácz István fordítása (1980)}

Ihol kedvem kerekedett, eszemben gondolat gerjedt: én elmennék énekelni, szép szavakat sorba szedni, mondanám az ősi mondát, regélném a régi regét. Szájamban szavak sürögnek, beszédek bőven buzognak, nyelvem hátán nyargalásznak, fogam között fickándoznak.

Jőj hát mellém, jó pajtásom, siess, vélem serdült vérem: kezdjük ketten az éneket, szedjünk szerbe vén verseket, ha egyszer így egybejöttünk, ketten kétfelől érkeztünk. Egymást csak elvétve látjuk, néhanap ha találkozunk Észak hideg határain, szegény szülőhazánk földjén.

Kapcsoljuk most kezünk egybe, fogas ujjunk fogjuk össze, úgy dalolgassuk danánkat, énekeljünk ékes verset: fiatalok figyelhessék, tudnivágyók tanúlhassák! Serdülők serény serege, nagy nemünk növendék népe hadd hallhassa hősök hírét, régtől ránk maradt regéket, 
vén Vejnemöjnen övéről, Ilmarinen kohójáról, Kaukomieli kardjáról, Joukahajnen jó íjáról, Pohjola fagyos földjéről, Kaleva kies tájáról.

Apám is ezt énekelte, fejsze nyelét farigcsálva, anyám is erre oktatott, míg fonalát fürgén fonta, én meg csöpp poronty a padlón, tejes szájú, tökéletlen, gyámoltalan, gyenge gyermek lebzseltem a lába előtt. Szállott a szó a Szampóról, híres Louhi hatalmáról; szavak törték szét a Szampót, Vipunennel varázs végzett, Louhit bájolás buktatta, Lemminkejnent léha játék.

Tanultam még más igét is, vettem titkos varázsverset: útak szélén szedegettem, hanga közül húzogattam, bozótokból bontogattam, cserjésekből csipegettem, füvek fejéből fosztottam, keréknyomról kerítettem, míg ballagtam bojtárkodva, gyatra gyermek, gyalogoltam mézillatú mezők mentén, tündérjárta tisztásokon tereltem Tarka tehenem, Csákóm nyomán csatangoltam.

Téli hideg is tanított, zúgó zápor nótát zengett, szellő szárnyas szókat súgott, hullám habja dallal zúgott, füsti fecske is ficsergett, vén fenyő fújt vidám verset.

Mind a szót fonálra füztem, gombolyagba göngyölgettem, szép szavaim jó szánkámba, kis kasomba kerítettem.

Haza húztam hû szánkámat, kincsemet csűrömbe csuktam, csür teteje alá tettem, rezes ládámba rejtettem.

Fagyban vacogott a versem, hétszám hevert a hidegben. Hozzam be hát a hidegről, kemény fagyok körme közűl? Hozzam be dalom a házba, verses ládám lóca végre? Térjek vele tetônk alá, szálfákból rótt szállásunkra? Nyissam kedves kincsesládám, tárjam fel tarka tetejét, gurítsam ki gombolyagom, bontsam fel fonalam bogát?

Dúdolnék derék dalokat, pengetnék pompás éneket, rozskenyeret ha rághatnék, tág torkomba sört tölthetnék. Ha sajnálják a sört tőlem, ha kedvemre nem kínálnak, szólok szomjúhozó szájjal: versemet vízzel vidítom. Dícsérjük hát napunk dallal, esténket édes énekkel, köszöntsük a kelő reggelt virradatkor víg versekkel! 
Szavamnak már szünni kéne, nyelvemnek nyugodni végre, nótámnak némulni immár, csengésének csendesedni. Szívós ló is szusszan egyet, hogyha hosszabb útat tett meg, kemény kasza is kicsorbúl, szénát mire mind levágja, lassúbb lesz a víz folyása, medrét mire mind bejárja, lustán lobog a tűz lángja, ha egész éjszaka égett.

Versem hogyne volna fáradt, nótám hogyne volna halkabb, hiszen szólt nap szállta óta, el nem csitúlt este óta.

Így hallottam, így tanultam, mások is mindig így mondták: „Nem hányja el minden habját bőven zuhogó zúgó sem, nem mondja el minden versét ékes szájú énekes sem. Jobb is, ha jócskán marad még, mint ha elapad az ének!" Elhallgatok, elnémulok, befejeztem, bevégeztem. Versem fonalát felszedem, gombolyagba göngyölítem, kiviszem kicsi kamrámba, csontos záram mögé csukom, honnan nem kaphat kiútat, kívűlre már nem kerűlhet, csak ha csontzáram kinyitom, torkom tágasra kitárom, fogaim sorát felbontom, makacs nyelvem megmozdítom.

De mit ér, ha énekelek, ha fújom bár folyton-folyvást, völgyeket végignótázom, fenyveseket mind felverem? Nem él az én édesanyám, szép szülém nem figyel reám, nem hall már hű szeretőm sem, nem tanúl dalolni tőlem. Reám csak fenyők figyelnek, tőlem tar gallyak tanúlnak, nyájas nyírlombok szeretnek, berkenye borúl vállamra.

Anyám elhalt kis koromban, gyenge gyermek, árva lettem: kis pacsirta köves parton, rigó roskadó romok közt. Mint pacsirta pityeregtem, mint a rigó rikoltoztam; maradtam rossz mostohámra, idegennek irgalmára.

Az kivert engem, kicsinykét, kiűzött, áldatlan árvát, házunk ordas oldalára, fagyos északi felére, hol hideg szelek szaggattak, téli viharok tépáztak.

Kis pacsirta, kódorogtam, árva madár, mendegéltem, gyenge gyermek, gyalogoltam, balga poronty, bujdokoltam. 
Minden záport megismertem, szilaj szelektől szenvedtem, vas hidegekben vacogtam, jajgattam fogas fagyokban.

Sokan vannak, végük sincsen, szeri-száma sincs azoknak, kik szigorú szóval szidnak, óbégatnak, ócsárolnak: egyik szavaimat szidja, másik hangomra haragszik, becsmérelik beszédemet, vádolnak, hogy visítozom, hamis hangon énekelek, fonákul fújom versemet.

Engedjétek meg, emberek, bocsássatok meg, jámborok, ha én, gyermek, gyengén fújtam, éktelenül énekeltem. Nem tanúltam tudósoktól, nem laktam én nagyuraknál, jobb igékhez nem jutottam, idegen szót nem szereztem. Mások mind tanúlni mentek: házunkat én el nem hagytam. Édesanyám egyedűl élt, mindig mellette maradtam. Tudásom otthon tanúltam, saját házunk héja alatt, szép szülém guzsalya mellett, bátyám faragó bakjánál, azt is csak kicsiny koromban míg pendelyes poronty voltam.

Ámde mégis, mindazáltal új dalok útján indúltam, útat leltem, jelet tettem, útmutató ágat törtem.

Messze megy majd ez az ösvény, új útak ágaznak szerte nálam nagyobb dalosoknak, éneket többet tudóknak most növekvők nemzetében, serdülőknek seregében.

\section{Szente Imre fordítása (2002)}

Kerekëdik arra kedvem, mind azt forgatom fejemben, hogy már dalra kéne kelni, ideje volna énëkëlni, versbe szëdni régvalókat, ősi dolgokról dalolni. Szók a számban olvadoznak, ínyëmet igék elöntik, nyelvemnek hëgyén nyüzsögnek, fogaim közül fakadnak.

Édës ëgyfelem, fivérëm, vélem ëgyívású vérëm! Füzögessünk dalt a dalba, öltögessünk szót a szóba, ëgyüttlétre ëgybegyűlve, kétfelől közel kerülve! Ugyan ritka benne részünk, szokatlan az ily szërëncse északi hideg hazánkban, sanyarú sorsú sarkvidékën.

Kéz a kézbe kapcsolódjon, ujj közébe ujj fonódjon, énëkëljünk szëbbnél szëbbet, tudományunktól mi tellik, kedveseinkkel közöljük, tudnivágyókat tanítsuk, ipërëdő ifjúságot, növekëdő nemzedékët szájrul szájra szálló szókra, ránk maradott ős regékre vén Väinämöinen övérül, Ilmarinen ül- 
lejérül, Kalandosnak kardvasárul, Joukahainen jó nyilárul puszta földjén Pohjolának, Kaleva kopár mezőin.

Így dalolgatott apám is, fejszéje nyelét faragva, szoktatott szülőanyám is, oktatott orsója mellett, pulyaként magam a padlón míg a térdinél totyogtam, gyámoltalan gyönge gyermëk, tejfölös bajszú bohócska. Szampó lön szavakbul ottan, Louhi lëlkëdzëtt igéktül; szótul lőn Szampó veszése, Louhinak lëgyőzetése, versëktől veszëtt Vipunen, Lemminkäinen léhaságtul.

Szókat máshol is szërëztem, titkot máskor is tanultam: gyalogúton gyüjtögettem, hangafü közül halásztam, csalitosbul cserkészgettem, bozótosbul bontogattam, fükalászrul fejtëgettem, kotortam kerékcsapábul, mikor kisbojtár koromban legelőkön lépëgettem, szagos szénazsombikosban, aranyos avarba' jártam barna Bimbónak nyomában, tarka barmomat terelve.

Fagy csípése dalt fakasztott, ritmusra dobolt a zápor; más zenéje volt a szélnek, hangja más futó haboknak, szó lëtt szárnyak lëbbenése, monda lombok moccanása.

Kincsëm kévébe kötöttem, gombolyagba göngyölgettem, csomót szán farába csaptam, kasos szánkómra kötöztem, hazahajtottam terümmel ëgyenëst a csűr elejbe, szárító padomra szórtam, rézládámba rëkkentëttem.

Heteket töltött ott hidegben, dalom dermesztő fagyokban. Hozzam-é hideg helyérül, fussak-é ki fagyba érte? Hurcoljam batyum a házba, rakjam ládám lócavégre, szelemën alá szobába, mënnyezet alá melegre?

Nyissam szëkrényét szavaknak, kincsës ládáját daloknak? Oldjam-é bogát batyumnak, csomagom csomós kötésit?

Válogatok vers javábul, gyönyörű dalokra gyújtok, rozskënyeret hogyha raknak, és itatnak árpalével. Házunkban ha sör hibázna, ëgy kis kvászszal is kivallom; nedvesebb talán a nóta, vizesebb lëszën a versëm, este ëgyütt üldögélve, összejöttünknek örülve, holnapig is tán kihúzva, virradatot is kivárva.

\section{***}

Számat immár zárni kéne, nyelvemre csomót kötözni, véget vetni verseimnek, szërteáradó szavaknak. Lovak is lëcsëndesëdnek, ha hosszú utat haladtak, kaszának vasa kicsorbul, nyári sarjúban suhogva; folyónak lohad futása, kanyargók közül kijutva; lankad tűznek lángolása, egész éëen át ha égëtt: csak dalom në csillapodna, énëkëm në csëndesëdne, mikor mondom este óta, kora alkonyattul kezdve? 
Hallom, így tartják a bölcsek, tapasztalat úgy tanítja: „Folyó bármi bőven árad, végsőkig vizét nëm adja; bármilyen dërék a dalnok, készletét ki nëm meríti. Jobb a hangulat, ha hagynak, mint ha közben mëgrëkednek."

Most hát mëgszünök-mëgállok, véget vetve szóözönnek. Versëm göngyölegbe gyüjtöm, gombolyagba gombolyítva rakom pajta padlására, csontlakat mögé becsukva, honnan képtelen kitörni, nëm szabadul szépszërével, csontok csattogása nélkül, állkapcák kopása nélkül, fogak futtatása nélkül, nyelvnek nyargalása nélkül.

Énëklésëmmel mit érëk, tengër szószátyárkodással, horhosokban hangicsálva, fenyvesëkben füttyögetve? Nincs anyám, ki rám figyeljën, rég nëm él szülém szëgényke; édësëm së hallgat éngëm, nëm dalol velem virágom: csak a fenyvesëk figyelnek, csak a szálfenyők szeretnek, nyírfalombok nyájaskodnak, berkënyék buzognak értem.

Anyámtul kicsi koromban, mamácskámtul itt maradtam, mint kövek között pacsirta, romok közt rigómadárka, hogy pacsirtaként pötyögjek, rikoltsak rigómadárul új anyám kezére adva, kényre-këgyre mostohámnak. Hamarost kivert a házbul, lódított szëgény lelencët széltül védetlen szobába, falu északi felére, hogy szelekkel messzeszálljak, viharokkal vándoroljak.

Bujdostam, piciny pacsirta, kerëngtem, kivert madárka, poroszkálva pusztaságban, vad vidékën vándorolva, kiszolgáltatva szeleknek, dörgésëktül darvadozva, vacogva veszëtt hidegben, sírva féktelen fagyokban.

Tudom, vannak most valakik, bizony, bőven is lëhetnek, akik rám ripakodnának, korholva kemény beszéddel; akik gúnyolják a nyelvem, fittyët hánynak hangjaimra, szidnak, hogy sokat szavalok, mëg hogy túl sokat zenélëk, bëcsmérëlnek, mint beszélëk, vállat vonnak verseimre.

Në érjën nehezteléstëk, szeretëtt atyámfiai, hogy gyerëkként gyatra módra, gyakorlatlanul gügyögtem. Hiszën iskolát së jártam, tudósabbaktul tanulni, szavakat szërëzni tőlük, választékosabb beszédët.

Mások iskolába jártak: én hazúl ki sëm kerültem, éd'sanyám körül forogva segéltem szëgény szülémnek. Otthon tudtam csak tanulni, pajtánk padlatán csücsülve, figyelve fonó anyámra, barkácsoló bácsikámra, gyarlócska gyerëkeszëmmel, zsandárzsebkendős koromban.

Mindazonáltal azonban bátran új csapást csináltam, nyomot nyitva, jel-kirakva dalnak új utat mutattam. Most hát erre mén az ösveny, próbálatlan pálya nyílik diadalmasabb dalosnak, érdëmësebb énëkësnek, ipërëdő ifjúságnak, növekëdő nemzedéknek. 


\section{Az elő- és utóhang finnül}

Mieleni minun tekevi, aivoni ajattelevi

lähteäni laulamahan, saa'ani sanelemahan, sukuvirttä suoltamahan, lajivirttä laulamahan. Sanat suussani sulavat, puhe'et putoelevat, kielelleni kerkiävät, hampahilleni hajoovat.

Veli kulta, veikkoseni, kaunis kasvinkumppalini! Lähe nyt kanssa laulamahan, saa kera sanelemahan yhtehen yhyttyämme, kahta'alta käytyämme! Harvoin yhtehen yhymme, saamme toinen toisihimme näillä raukoilla rajoilla, poloisilla Pohjan mailla.

Lyökämme käsi kätehen, sormet sormien lomahan, lauloaksemme hyviä, parahia pannaksemme, kuulla noien kultaisien, tietä mielitehtoisien, nuorisossa nousevassa, kansassa kasuavassa: noita saamia sanoja, virsiä virittämiä vyöltä vanhan Väinämöisen, alta ahjon Ilmarisen, päästä kalvan Kaukomielen, Joukahaisen jousen tiestä, Pohjan peltojen periltä, Kalevalan kankahilta. 
Niit' ennen isoni lauloi kirvesvartta vuollessansa; niitä äitini opetti

väätessänsä värttinätä, minun lasna latialla eessä polven pyöriessä, maitopartana pahaisna, piimäsuuna pikkaraisna. Sampo ei puuttunut sanoja eikä Louhi luottehia: vanheni sanoihin Sampo, katoi Louhi luottehisin, virsihin Vipunen kuoli, Lemminkäinen leikkilöihin.

Viel' on muitaki sanoja, ongelmoita oppimia: tiehesta tempomia, kanervosta katkomia, risukoista riipomia, vesoista vetelemiä, päästä heinän hieromia, raitiolta ratkomia, paimenessa käyessäni, lasna karjanlaitumilla, metisillä mättähillä, kultaisilla kunnahilla, mustan Muurikin jälessä, Kimmon kirjavan keralla.

Vilu mulle virttä virkkoi, sae saatteli runoja.

Virttä toista tuulet toivat, meren aaltoset ajoivat. Linnut liitteli sanoja, puien latvat lausehia.

Ne minä kerälle käärin, sovittelin sommelolle. Kerän pistin kelkkahani, 
sommelon rekoseheni;

ve'in kelkalla kotihin,

rekosella riihin luoksi;

panin aitan parven päähän

vaskisehen vakkasehen.

Viikon on virteni vilussa,

kauan kaihossa sijaisnut.

Veänkö vilusta virret, lapan laulut pakkasesta, tuon tupahan vakkaseni, rasian rahin nenähän, alle kuulun kurkihirren, alle kaunihin katoksen, aukaisen sanaisen arkun, virsilippahan viritän, kerittelen pään kerältä, suorin solmun sommelolta.

Niin laulan hyvänki virren, kaunihinki kalkuttelen ruoalta rukihiselta, oluelta ohraiselta. Kun ei tuotane olutta, tarittane taarivettä, laulan suulta laihemmalta, vetoselta vierettelen tämän iltamme iloksi, päivän kuulun kunniaksi, vaiko huomenen huviksi, uuen aamun alkeheksi.

Suuni jo sulkea pitäisi, kiinni kieleni sitoa, laata virren laulannasta, herätä heläjännästä.

Hevonenki hengähtävi matkan pitkän mentyänsä, rautanenki raukeavi 
kesäheinän lyötyänsä, vetonenki vierähtävi joen polvet juostuansa, tulonenki tuikahtavi yön pitkän palettuansa; niin miks' ei runo väsyisi, virret vienot vierähtäisi illan pitkiltä iloilta, päivänlaskun laulannoilta?

Noin kuulin saneltavaksi, toisin tutkaeltavaksi:

"Eipä koski vuolaskana laske vettänsä loputen, eikä laulaja hyväinen laula tyynni taitoansa. Mieli on jäämähän parempi kuin on kesken katkemahan."

Niin luonen, lopettanenki, herennenki, heittänenki. Kerin virteni kerälle, sykkyrälle syylättelen, panen aitan parven päähän, luisten lukkojen sisälle, jost' ei pääse päivinänsä, selviä sinä ikänä ilman luien lonsumatta, leukojen leveämättä, hammasten hajoamatta, kielen keikkelehtämättä.

Mitäs tuosta, jos ma laulan, jos ma paljoki pajahan, jos laulan jokaisen lakson, joka kuusikon kujerran! Ei ole emo elossa, oma vanhin valvehella eikä kulta kuulemassa, oma armas oppimassa: on mua kuuset kuulemassa, 
hongan oksat oppimassa, koivun lehvät lempimässä, pihlajat pitelemässä.

Piennä jäin minä emosta, matalana maammostani. Jäin kuin kiuruksi kivelle, rastahaksi rauniolle, kiuruna kivertämähän, rastahana raikkumahan, vaimon vierahan varahan, ehtohon emintimäisen.

Se mun karkotti, katalan, ajoi lapsen armottoman tuulipuolelle tupoa, pohjaspuolelle kotia, vieä tuulen turvatointa, ahavaisen armotointa.

Sainpa, kiuru, kiertämähän, lintu kurja, kulkemahan, vieno, maita vieremähän, vaivainen, vaeltamahan, joka tuulen tuntemahan, ärjynnän älyämähän, vilussa värisemähän, pakkasessa parkumahan.

Moni nyt minulla onpi, usea olettelevi virkkaja vihaisen äänen, äänen tuiman tuikuttaja. Ken se kieltäni kirosi, kenpä ääntä ärjähteli; soimasi sorisevani, lausui liioin laulavani, pahasti pajattavani, väärin virttä vääntäväni. 
Elkätte, hyvät imeiset, tuota ouoksi otelko, jos ma, lapsi, liioin lauloin, pieni, pilpatin pahasti! en ole opissa ollut, käynyt mailla mahtimiesten, saanut ulkoa sanoja, loitompata lausehia.

Muut kaikki oli opissa, mie en joutanut kotoa emon ainoan avusta, yksinäisen ympäriltä. Piti oppia kotona, oman aitan orren alla, oman äitin värttinöillä, veikon veistoslastusilla, senki piennä, pikkaraisna, paitaressuna pahaisna.

Vaan kuitenki kaikitenki la'un hiihin laulajoille, la'un hiihin, latvan taitoin, oksat karsin, tien osoitin. Siitäpä nyt tie menevi, ura uusi urkenevi laajemmille laulajoille, runsahammille runoille nuorisossa nousevassa kansassa kasuavassa. 


\section{ABSTRACT FROM HIISI'S ELK TO THE WONDERDEER}

The Finnish epic Kalevala has been translated into Hungarian five times in the time span of over a century, as follows (in chronological order, mentioning the names of the authors): Ferdinánd Barna 1871, Béla Vikár 1909, Nagy Kálmán 1972, István Rácz 1976, and Imre Szente 1987. Fragments of the epic were translated by Antal Reguly, Pál Hunfalvy and István Fábián in the 19th century, as well as by Géza Képes and Domokos Varga in the 20th century. In my book I am going to deal only with the complete translations. The choice of my topic was mainly motivated by the absence in Hungarian Kalevala research and literature of studies focusing on the comparative study and analysis of the translations of the epic employing a translation studies framework.

The aim of this book is to locate these Hungarian texts in the Hungarian literary polysystem through a comparative study of the five complete Hungarian translations, investigating these translations both linguistically and in their cultural historical context.

The present analysis uses Itamar Even-Zohar's polysystemic theory, further developed by Gideon Toury's Descriptive Translation Studies, and by José Lambert and André Lefevere's works as well.

The two literary systems I am dealing with, the Hungarian and the Finnish, occupy a peripheric position in the (Western)European macrosystem, the main reason being the "isolation" of the two languages in (Western)Europe. Both are Finno-Ugric languages, and this fact leads further than the simple scheme of "two kindred languages"; in different ages it is the attitude towards each other based on the affinity of languages that determines the mode of the approach to translations. The analysis is based on the relations that may have influence on the reception of the translations: the context in which the source text and the target texts were born (the strategies followed by Lönnrot, the compiler/author and by the Hungarian translators in the creation of the texts) and the critics. This is followed by the comparative analysis of the source and target texts, examining the translators' solutions regarding the form of the epic: rhythm, metre, schemes (alliteration, parallelism) and the translators' interpretation of the text as regards the Kalevala as original myth, as well as the emphasis laid on the transmission of tradition from one generation to the other and on popular motives and features. I introduced the notion of a "Finno-Ugric network" as a main means of constructing an individual character. 
The network itself implies the existence of text systems (all texts written in a FinnoUgric language) and of a conceptual grid (a tool of identification, it concentrates on similarities that may be necessary for its creation, as well on differences emphasizing those "alterities" that differentiate the Finno-Ugric network from the concepts determined by the Western network).

The study revealed that the existence of the Finno-Ugric network was crucial in the reception of the first two Hungarian translations. The intentions of Ferdinánd Barna were to fill in the gap generated by the absence of a national epic from the Hungarian literary system, under the flag of Finno-Ugric affinity. He tried to show how a major Hungarian national epic could be created using poetic means borrowed from the Finnish epic. This attempt failed for several reasons. First, the cultural centre in Hungary at the end of the 19th century did not consider the epic poem to be an adequate genre for a major national epic work. Second, the translator was inconsequential by sustaining the conceptual grid only in the Notes-part of the edition and also having the idea to reconstruct a Finno-Ugric mythology.

The second translator, Béla Vikár, saw the Kalevala as a genre pattern and as a starting point for tracking down a Finno-Ugric mythology that could serve as a basis for a conceptual grid, but without the idea of reconstructing this mythology. The success of Vikár's translation in the 1930s and the following years was due to the joint effect of several factors. Vikár combined in his text archaistic language with a dialectical one and used a domesticating strategy regarding the formal solutions, translating or transcribing Finnish names into Hungarian and adapting the Kalevala-metre and rhythm to Hungarian accentual verse of $4 / 4$ rhythm with end rhyme. With a sense for the literary politics of his age the translator chose Dezso" Kosztolányi, a well-known poet in the centre of the literary system, to write an introductory essay for the 1935 edition of his translation at the time of the FinnoUgric movement, where personal and semi-official Hungarian-Finnish relations turned into official relations. The cult towards the translator also had a key-role in the succes of the translation and in gaining a central position in the Hungarian polysytem.

The situation started to change in the 50s along with the change of paradigm in translation studies. Instead of domestication the maintenance of the foreign sonority, for example through formal solutions, was considered acceptable. Archaistic and dialectical language was also criticized.

The first re-translation, Kálmán Nagy's, uses the common Hungarian idiom of the 70s. The translator's person led to an ambivalent reception for this work. As a Romanian Hungarian he was unknown to critics in Hungary, and his early death, which preceded the publication of his work in the communist Romania, made his person and life stand in the centre of attention. His translation received only meagre critical response. Kálmán Nagy's translation may be considered as centring on the source culture and also on the text by being loyal to the distinctive forms of the Finnish epic. He emphasized a distant attitude towards the text by preserving the foreign sonority, that is the Finnish orthography of names. He did not wish to borrow the genre as a pattern or to creat some kind of a Finno-Ugric network. In his interpretation the Kalevala is the original history of the Finnish people, a product of the Finnish collective subconscious and of Lönnrot at the same time. 
The language used by the fourth translator of the Kalevala, István Rácz, is close to Nagy's language. His methods had the aim of domesticating the source-text, following Vikár's example in formal solutions, and he also translates or transcribes Finnish names into Hungarian.

The last complete Hungarian Kalevala, Imre Szente's translation, which was published twice during past decade in Hungary, may also be considered to be domesticated due to the fact that its vocabulary includes notions borrowed from the Hungarian cultural sphere. The textual analysis partly confutes this, since it proves the use of Finnish orthography (thereby the preservation of the foreign nature of the text) contrary to the domesticating intention.

Vikár's translation held its central position for decades, but was gradually peripheralized by the new re-translations. Even if in the hypothesis I stated that this position could only be taken by a text based on a totally different concept, after analysis I reached the conclusion that it was Rácz's translation that has occupied this place. The reason why this may be the case is the employment of a translation strategy in many forms similar to Vikár's, as well as the translator's original view on poetics: the creation of a Hungarian Kalevala based on alliteration. 



\section{REZUMAT DE LA CERBUL LUI HIISI PÂNĂ LA CERBUL MIRACULOS}

Kalevala a fost tradusă în limba maghiară de cinci ori. În ordine cronologică, menționând numele autorilor, acestea sunt: Ferdinánd Barna (1871), Béla Vikár (1909), Nagy Kálmán (1972), István Rácz (1976), Imre Szente (1987). Au fost traduse de asemenea fragmente de către Antal Reguly, Pál Hunfalvy şi István Fábián în secolul XIX, respectiv Géza Képes şi Domokos Varga în secolul XX. Cartea tratează numai traducerile complete ale epopeii. Alegerea temei a fost motivată în primul rând de lipsa unei lucrări de specialitate care să pună accent pe traducerile Kalevalei, să analizeze recepția acestor traduceri, respectiv să le poziționeze într-un context bazat pe cadrul creat de teoria traducerii.

Obiectivul studiului este de a stabili locul textelor maghiare în polisistemul maghiar, prin analiza comparativă a traducerilor, acestea fiind investigate din punct de vedere lingvistic în cadrul contextului cultural-istoric al epocii în care au fost redactate. Analiza se bazează pe teoria polisistemelor elaborată de Itamar Even-Zohar, teoria descriptivă a traducerii a lui Gideon Toury, respectiv lucrările din domeniu având ca autori pe José Lambert şi André Lefevere.

Cele două sisteme literare cu care se ocupă cartea (cea maghiară şi cea finlandeză) ocupă un loc periferic în macrosistemul (vest)-european. Acest lucru este cauzat în primul rând de faptul că cele două limbi nu sunt înrudite cu limbile vest-europene. Fiind vorba de două limbi fino-ugrice, efectele legăturii istorice depăşesc schema simplă a "două limbi înrudite", deoarece modul de abordare al traducerii este determinată în diferitele perioade tocmai de relația reciprocă bazată pe înrudirea lingvistică.

Analiza se bazează pe relațiile care pot influența recepția traducerilor: contextul redactării textului sursă şi al traducerilor (strategiile redactorului/autorului Lönnrot şi ale traducătorilor maghiari în realizarea textului), respectiv al criticii. Urmează analiza comparativă a textelor țintă şi a textului sursă, examinând soluțiile traducătorilor în privința formei epopeii: ritmul şi metrul kalevalian, precum şi figurile de stil, ca aliterația şi paralelismul. Sunt examinate interpretările referitoare la Kalevala care se desprind din textul maghiar, epopee considerată ca fiind povestea unui mit originar, respectiv locul din text al descrierii trăsăturilor populare și transmiterii tradițiilor de la o generație la alta. 
Studiul defineşte noțiunea de "rețea fino-ugrică", ca principal mijloc de construire a caracterului individual. Rețeaua în sine implică existența sistemelor de texte (toate textele scrise într-o limbă fino-ugrică) şi a unui tipar conceptual. Acest tipar este de fapt un mijloc de identificare focalizând pe similitudinile care pot fi utilizate pentru construcția rețelei fino-ugrice, respectiv pe "alteritățile" care îl deosebesc de tiparul conceptual determinat de rețeaua vestică.

Analiza demonstrează că existența rețelei fino-ugrice a fost crucială în recepția primelor două traduceri. Intenția traducătorului Ferdinánd Barna a fost acela de a umple - sub semnul înrudirii lingvistice - golul din cultura maghiară datorat lipsei unei epopei proprii. El a încercat să creeze o operă epică națională maghiară prin intermediul mijloacelor împrumutate din epopeea finlandeză. Eşecul acestei strădanii a avut cauze multiple. În primul rând, centrul dominant al culturii maghiare de la sfârşitul secolului XIX a încetat să considere genul epopeii ca fiind corespunzător pentru redactarea operei epice naționale. În al doilea rând, traducătorul a fost destul de inconsecvent în construcția tiparului conceptual, acesta fiind susținut doar în notele ediției. În acest fel, ideea sa de a reconstrui mitologia fino-ugrică nu a avut baze solide.

Cel de-al doilea traducător, Béla Vikár, a privit Kalevala în principal ca un model al genului, respectiv un punct de plecare legat de mitologia finlandeză, pe care se poate construi un tipar conceptual, însă fără ideea reconstruirii mitologiei fino-ugrice. Succesul traducerii sale începând cu anii 1930 este datorat existenței simultane a mai multor factori. Traducerea lui Vikár a combinat limbajul arhaic cu dialectele. Traducătorul a folosit o strategie de domesticare a textului care reiese din soluțiile privind forma: traducerea sau transcrierea numelor proprii finlandeze, precum şi adaptarea ritmului şi metrului kalevalian în versuri cu un ritm accentual 4/4 cu rime la sfârşit de rând. Bun cunoscător al politicii literare a timpului, traducătorul l-a ales pe Dezső Kosztolányi, un poet de seamă din centrul sistemului literar maghiar, să redacteze eseul introductiv al ediției din 1935 al Kalevalei, într-o perioadă în care mişcările fino-ugrice, relațiile personale şi semioficiale dintre Ungaria şi Finlanda au început să se oficializeze. În plus, cultului traducărorului din acea vreme a contribuit la rândul său la succesul traducerii şi obținerea poziției centrale în sistemul literar maghiar.

Primele schimbări au apărut în anii 1950, odată cu modificarea paradigmei legate de abordarea traducerilor, în cursul căreia principiul menținerii sonorității străine a luat locul strategiilor de domesticare. Folosirea limbajul arhaic şi al dialectelor a fost la rândul său criticată.

Prima retraducere, cea a lui Kálmán Nagy, a folosit limbajul comun al anilor '70. Având în vedere persoana traducătorului, recepția primei retraduceri a fost una ambivalentă. Ca maghiar din Transilvania, acesta era necunoscut criticii din Ungaria, care abia s-a pronunțat în privința traducerii. Totodată, decesului său survenit în România comunistă, înainte de apariția traducerii, a făcut ca personalitatea sa să capete o importanță sporită. Prin fidelitatea sa față de formele distinctive ale Kalevalei, opera lui Kálmán Nagy poate fi considerată deopotrivă centrată pe cultura sursă şi pe text. Nagy subliniază alteritatea epopeii prin păstrarea sonorităţii străine - cea a numelor proprii finlandeze. El nu a avut intenția de a trata genul ca fiind un model, sau de a crea o rețea fino-ugrică. În interpretarea sa, Kalevala este 
deopotrivă istoria genezei poporului finlandez, produsul lui Lönnrot şi al conştiinței comune finlandeze.

Limbajul traducerii lui István Rácz, cel de-al patrulea traducător al Kalevalei, se apropie de cel al lui Nagy: ambii utilizează limbajul comun al anilor 1970. Însă, metodele de domesticare ale lui Rácz se apropie mai mult de exemplul lui Vikár în privința traducerii sau transcrierii numelor proprii finlandeze în limba maghiară.

Ultima traducere completă în limba maghiară, cea a lui Imre Szente, publicată de două ori în Ungaria în anii 2000, se concentrează asupra culturii țintă. Domesticarea constă în utilizarea noțiunilor aparținând sferei culturale maghiare, prin urmare aceasta a devenit traducerea având gradul de domesticare cel mai pronunțat în literatura maghiară. Totodată, analiza relevă faptul că textul lui Szente este cel mai apropiat - după traducerea lui Nagy - de textul sursă.

Traducerea lui Vikár a păstrat poziția centrală în cadrul sistemului timp de mai multe decenii, însă a fost mutat treptat spre periferie de retraducerile din cea de-a doua jumătate a secolului XX. Deși am formulat ca ipoteză a cercetării faptul că numai o traducere având o concepție total diferită poate să submineze poziția centrală al textului realizat Vikár, în urma analizei am ajuns la concluzia că poziția a fost ocupată de textul lui Rácz. Acest lucru se explică prin adoptarea şi aplicarea unei strategii de traducere apropiate de cea a lui Vikár, respectiv modul de abordare individual al particularităților poeziei - realizarea Kalevalei bazate pe aliterații. 

AKalevala a finn kultúra mellett a magyarban töltötte be a legjelentősebb szerepet. Ez a könyv a finn eposz magyar fordításaival foglalkozik. A témaválasztást az indokolta, hogy hiányzik a magyar Kalevala-kutatások és Kalevala-irodalom színteréről egy olyan munka, amely a fordításokat helyezi a kutatás fókuszába. Ez a munka fordításelméleti keretben vizsgálja a Kalevala-fordításokat és fogadtatásukat, valamint bemutatja azokat a stratégiákat és megoldásokat, amelyeket az első fordítók arra használtak, hogy célszövegeikkel a magyar irodalomból hiányzó nemzeti eposzt legalább részben pótolják.

ISBN 978-606-8178-18-9

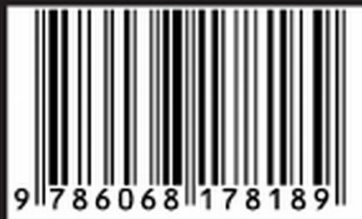

